\title{
Favelados e pobladores nas ciências sociais a construção teórica de um movimento social
}

\author{
Alexis Cortés
}

CORTÉS, A. Favelados e pobladores nas ciências sociais: a construção teórica de um movimento social [online]. Rio de Janeiro: EDUERJ, 2018, 391 p. Sociedade \& política collection. ISBN: 978-857511-477-3. https://doi.org/10.7476/9788575114773.



All the contents of this work, except where otherwise noted, is licensed under a Creative Commons Attribution 4.0 International license.

Todo o conteúdo deste trabalho, exceto quando houver ressalva, é publicado sob a licença Creative Commons Atribição $\underline{4.0}$.

Todo el contenido de esta obra, excepto donde se indique lo contrario, está bajo licencia de la licencia $\underline{\text { Creative }}$ Commons Reconocimento 4.0. 
FAVELADOS E POBLADORES NAS

CIÊNCIAS SOCIAIS

A construção teórica de um movimento social 
UNIVERSIDADE DO ESTADO DO RIO DE JANEIRO

Reitor

Ruy Garcia Marques

Vice-reitora

Maria Georgina Muniz Washington

EDITORA DA UNIVERSIDADE DO ESTADO DO RIO DE JANEIRO

uerj Conselho Editorial

Glaucio José Marafon (presidente)

Henriqueta do Coutto Prado Valladares

Hilda Maria Montes Ribeiro de Souza

Italo Moriconi Junior

José Ricardo Ferreira Cunha

Lucia Maria Bastos Pereira das Neves

Luciano Rodrigues Ornelas de Lima

Maria Cristina Cardoso Ribas

Tania Maria Tavares Bessone da Cruz Ferreira

Anibal Francisco Alves Bragança (EDUFF)

Katia Regina Cervantes Dias (UFRJ)

\section{IESP.UERJ}

Instituto de Estudos Sociais e Políticos

\section{Coleção Sociedade e Política}

Coordenadores

Breno Bringel

João Feres Júnior

Conselho cientifico

Antônio Sérgio Guimarães (USP)

Fabiano Santos (IESP-UERJ)

Flávia Biroli (UnB)

Gilberto Hochman (FIOCRUZ)

José Maurício Domingues (IESP-UERJ)

Leonardo Avritzer (UFMG)

Maria Stella Grossi Porto (UnB)

Pablo Gentili (CLACSO)

Rachel Meneguello (UNICAMP)

Sergio Costa (Frei Universität - Alemanha) 


\section{Alexis Cortés}

\section{FAVELADOS E POBLADORES NAS CIÊNCIAS SOCIAIS}

\section{A construção teórica de um movimento social}

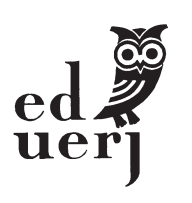

Rio de Janeiro

2018 
Copyright (C) 2018, Alexis Cortés.

Todos os direitos desta edição reservados à Editora da Universidade do Estado do Rio de Janeiro. É proibida a duplicação ou reprodução deste volume, ou de parte do mesmo, em quaisquer meios, sem autorização expressa da editora.

\section{EdUERJ}

Editora da UNIVERSIDADE DO ESTADO DO RIO DE JANEIRO

Rua São Francisco Xavier, 524 - Maracanã

CEP 20550-013 - Rio de Janeiro - RJ - Brasil

Tel./Fax.: 55 (21) 2334-0720 / 2334-0721

www.eduerj.uerj.br

eduerj@uerj.br

Editor Executivo
Coordenadora Administrativa
Coordenadora Editorial
Assistente Editorial
Coordenador de Produção
Capa
Projeto Gráfico
Diagramação
Revisão

Glaucio Marafon

Elisete Cantuária

Silvia Nóbrega

Thiago Braz

Mauro Siqueira

Júlio Nogueira

Emilio Biscardi

Editora Morandi

Revisão

Magdalena Toledo/IESP

\section{CATALOGAÇÃO NA FONTE \\ UERJ/REDE SIRIUS/NPROTEC}

C828 Cortés, Alexis.

Favelados e pobaldores nas ciências sociais : a construção teórica de um movimento social / Alexis Cortés. - Rio de Janeiro : EdUERJ, 2018.

392 p. - (Sociedade \& política)

ISBN 978-85-7511-478-0

1. Sociologia. 2. Movimentos Sociais. I. Título. 
Una clara conciencia teórica en cuanto a las implicaciones ideológicas del propio pensamiento y una actitud vigilante orientada exclusivamente en la búsqueda de la verdad constituyen dos condiciones esenciales de todo quehacer científico. La imparcialidad absoluta es quizá tan sólo una meta ideal hasta cierto punto inalcanzable, pero la honestidad moral y la claridad intelectual $[. .$.$] son calidades$ indispensables para el investigador.

Gino Germani 


\section{ADVERTÊNCIA E AGRADECIMENTOS}

A começos da década de 1970, um grupo de pesquisadores publicou um artigo intitulado "De invasores a invadidos" (RODRÍGUEZ et al, 1972). Nesse texto, descrevia-se como a generalização das invasões de terra dos moradores das periferias das cidades latino-americanas foi seguida por uma nova "invasão", dessa vez, dos pesquisadores sociais, que esperavam confirmar e, também prever, a explosão social que poderia vir dos bairros populares.

Menciono tal fato porque este livro basicamente se poderia resumir como um intento de inversão desse processo de "invasão", ao estudar não os moradores, mas os que fizeram deles seu principal sujeito de estudo. Inversão também porque minha trajetória familiar está fortemente ligada ao movimento de pobladores: venho de uma família de la Legua, conhecido bairro popular de Santiago, que se instalou, um mês depois da tomada, em la Victoria, talvez o bairro popular chileno mais emblemático. Além do mais, sou filho de militantes da Coordinadora Metropolitana de Pobladores, que, durante a década de 1980, foi o principal organismo de pobladores para a implementação da política de Rebelião Popular de Massas do Partido Comunista contra a ditadura. Aclaro que esses antecedentes são mencionados para explicar meu lugar de enunciação, e não porque considere que outorguem mais autoridade ao meu argumento. Boa parte dos debates aqui desenvolvidos ecoam discussões ouvidas na minha casa, que modelaram meu interesse pelos movimentos urbanos. 
Essa motivação acompanhou-me até o Rio de Janeiro, onde fiz meus estudos de pós-graduação. $\mathrm{O}$ texto que está nas suas mãos é o resultado de uma pesquisa de doutorado financiada pelo CNPq, durante quatro anos, que foi premiada em 2015 como a melhor tese de sociologia defendida no Instituto de Estudos Sociais e Políticos (IESP-UERJ) durante o ano 2015. Ela foi adaptada e ajustada para sua divulgação sem modificar substancialmente o argumento original, embora nos últimos anos tenha aprofundado vários dos pontos aqui tratados, assim como tive a chance de ampliar minha interlocução com colegas com interesses similares aos meus. Embora acredite que essas influências recentes poderiam enriquecer esta versão, optei por me manter fiel à obra tal qual foi defendida na banca de doutorado e que contou com a participação dos professores: Márcia Leite (PPCIS-UERJ), Vicente Espinoza (IDEA-USACH), Breno Bringel (IESP-UERJ) e José Maurício Domingues (IESP-UERJ). Aos que agradeço por seus comentários e atenta leitura.

Este livro não teria sido possível sem o apoio e estímulo dos meus professores e colegas do IESP-UERJ, centro herdeiro do antigo Instituto Universitário de Pesquisas do Rio de Janeiro (IUPERJ). Sinto-me privilegiado por ter compartilhado com uma geração extraordinária de jovens pesquisadores brasileiros e latino-americanos num momento de expansão das políticas científicas do Brasil. Tive a sorte de contar, desde o meu mestrado, com a orientação do professor Luiz Antônio Machado da Silva, como ele mesmo gosta de dizer, verdadeira "relíquia" dos estudos urbanos cariocas. A absoluta liberdade para desenvolver minha tese, onde ele próprio virava "sujeito de estudo", foi indispensável para este trabalho, assim como suas agudas observações e críticas que foram sempre um estímulo para densificar minhas inquietudes. Sua orientação permitiu filiar-me a alguns dos mais respeitados e admirados pesquisadores das favelas cariocas (alguns deles aparecem aqui como sujeitos deste estudo). Vários professores do 
IESP continuam influindo também nas minhas preocupações e na maneira de abordar e compreender os fenômenos sociais. Gostaria de sintetizar na figura de três deles essa marca: José Maurício Domingues, Adalberto Cardoso e Breno Bringel.

No Chile, tive a oportunidade de dialogar e discutir com um amplo número de colegas sociólogos e historiadores, principalmente sobre os movimentos sociais, e em particular sobre os pobladores. Porém, gostaria de resumir essa dívida intelectual destacando dois deles: o historiador Gonzalo Cáceres (PUC-Chile), por sua generosidade intelectual e inesgotável capacidade crítica, e o sociólogo Vicente Espinoza (IDEA-USACH), não apenas por ter participado de minha banca de doutorado, mas sobretudo por ter escrito Para uma história dos pobres da cidade.

Esta obra não teria vindo à luz sem o apoio do Departamento de Sociologia da Universidade Alberto Hurtado no Chile, onde trabalho como professor desde o ano 2014, e dos meus colegas, pois me deram todas as condições para transformar o exercício acadêmico da tese neste livro. Além disso, o interesse de muitos deles sobre a porosa relação entre ciência e sociedade tem me permitido continuar com esta linha de pesquisa com mais ferramentas teóricas.

Agradeço também a minha esposa Magdalena Toledo por seu apoio incondicional em todos estes anos, ainda mais por sua paciência com minhas permanentes dúvidas de português. Peço desculpas para todos os que de alguma forma me ajudaram a concluir este livro e que omito, mas as últimas palavras de agradecimento são para meus pais, principalmente porque o que aprendi com e deles foi alimentando pouco a pouco e inesperadamente este livro. 


\section{SUMÁRIO}

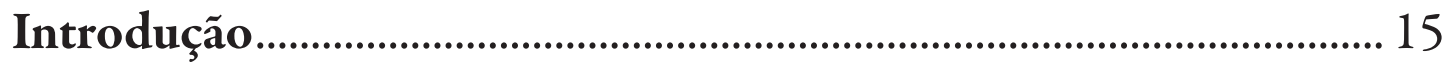

Capítulo 1 - Da questão social à questão social urbana ...................... 27

1.1. Os mitos locais clássicos de interpretação da questão social .............................................................................................. 34

1.2. Historiografia e Movimento Operário:

algumas semelhanças

Capítulo 2 - Favelados e pobladores nas teorias da marginalidade ........................................................................6 61

2.1. Fontes teóricas e precursores ........................................................... 61

2.2. A versão dualista da marginalidade ............................................. 72

2.3. Marginalidade como polarização: a leitura econômico-estrutural............................................................................. 92

Capítulo 3 - O Movimento de Pobladores como movimento social urbano (1970-73)

3.1. Os marginalizados como ponta de lança da transformação social: Frantz Fanon e a marginalidade..................... 116

3.2. Os pesquisadores do CIDU 121

3.3. A Metamorfose do Pensamento Urbano de

Manuel Castells e Os Movimentos Sociais Urbanos 
Capítulo 4 - Rio de Janeiro, ceticismo acadêmico e racionalidade favelada

4.1. A desmarginalização da questão urbana no

Rio de Janeiro

4.2. Marginalidade e Exército de Reserva: a leitura paulista

da urbanização.

4.3. São Paulo e a promessa dos Movimentos

Sociais Urbanos

4.4. Rio de Janeiro e a perspectiva Anti-Movimentos

Sociais Urbanos

4.5. Movimentos Sociais Urbanos no Brasil, promessa descumprida?

Capítulo 5 - Novidade e negação do Movimento de

\section{Pobladores na Ditadura Militar Chilena}

5.1. O Movimento de Pobladores como movimento comunitário. 256

5.2. O Movimento de Pobladores como anti-movimento social 283

5.3. O Movimento de Pobladores como construtor do espaço popular

5.4. Movimento de Pobladores, entre a novidade

e a negação.

Capítulo 6 - Anos 1990, a descontinuidade ou quando antigos atores saem de cena

6.1. Os pobladores nas margens da transição democrática

6.2. Do movimento favelado à violência urbana 
Capítulo 7 - Considerações finais: repensar os movimentos para repensar as ciências sociais.............................................................345

7.1. Temporalidade e espaço nos movimentos urbanos 347

7.2. Velhos/novos desafios para a compreensão dos movimentos de pobladores e favelados.

Referências. 361

Sobre o autor 391 


\section{INTRODUÇÃO}

Os pobres urbanos das cidades latino-americanas, durante o século passado, estiveram no centro dos debates dos intelectuais do continente. A reflexão em torno deles alimentou um vasto corpus teórico que tentou compreender a especificidade da questão social nas metrópoles da América Latina, procurando enquadrar a ação coletiva dos moradores das diversas formas de habitação popular em esquemas analíticos coerentes com projetos políticos que disputavam o direito de conduzir as sociedades dependentes pela trilha do desenvolvimento.

Compreendidos, por alguns autores, como massa de manobra potencialmente à disposição de projetos populistas ou revolucionários, como força auxiliar do proletariado, ou como os principais protagonistas de uma nova forma de luta de classes, como diria Manuel Castells (CASTELLS, 1972), apesar do caráter secundário da contradição que os define (consumo/habitação), os marginais ou marginalizados estiveram no núcleo dos debates políticos e teóricos em determinadas conjunturas. Daí que a célebre expressão de Touraine (TOURAINE, 1987), aparentemente paradoxal, sobre "a centralidade dos marginais", define um traço capital do tópico da ação coletiva popular na América Latina.

O alvo da reflexão que quero propor é mostrar qual é o papel das ciências sociais na constituição e reconhecimento como atores políticos dos pobres urbanos das cidades do Rio de Janeiro e de Santiago do Chile: favelados e pobladores. Em outras palavras, o que pretendo responder é em que medida as ciências sociais con- 
tribuíram para a constituição do Movimento de Pobladores e de Favelados, compreendendo ambos os movimentos também como uma construção teórica.

Embora ambas as categorias, favelados e pobladores, correspondam a uma forma particular dos pobres urbanos, e não à sua totalidade ${ }^{1}$, essas etiquetas concentram boa parte do debate sobre a questão social urbana no continente. A favela provavelmente é a forma de habitação popular que maior impacto teve no imaginário sobre pobreza urbana dentro e fora da academia; enquanto a forma de habitação que deu origem aos pobladores teve uma repercussão chave no reconhecimento de um movimento social de caráter eminentemente urbano que, desde uma posição subalterna, é capaz de gerar transformações sociais profundas, não apenas na estrutura urbana como na sociedade em geral. Daí a importância de compreender o papel específico das ciências sociais na conformação destes dois movimentos. Porém, em relação à favela, é preciso fazer uma ponderação. Licia Valladares (1978a) chama a atenção para os "conjuntos" de habitação popular precisamente para contrastar o "favelocentrismo" dos estudos sobre moradia popular. A favela não é o único espaço de habitação dos pobres do Rio de Janeiro, mas constitui um tópico (SILVA, 2012a), ou seja, a favela é um assunto-lugar com características dinâmicas, salvo por sua posição subalterna na trama urbana que, em um sentido amplo, incorpora tematicamente outros tipos de moradia popular, na medida em que é o núcleo da reflexão da questão social urbana no Rio de Janeiro.

Partirei do suposto de que na relação entre ciências sociais e os movimentos sociais estudados opera uma sorte de "dupla hermenêutica" (GIDDENS, 1978), ou seja, um processo de reflexibilidade mutuamente influente entre o movimento social e as

1 Nem todos os favelados são pobres, nem todos os pobres são favelados; o mesmo vale para os pobladores. 
ciências sociais. Seguindo a argumentação de Anthony Giddens (1978), as ciências sociais estão inevitavelmente envolvidas com a "dupla hermenêutica" toda vez que os cientistas sociais buscam analisar e compreender um mundo pré-interpretado, pois a conduta social humana implica um processo constante de criação e reprodução dos quadros de significância de sua vida social. Logo, a descrição que o cientista social realiza da vida social é produto dos mesmos tipos de habilidades daqueles que são seu objeto de estudo. Assim, o cientista social não apenas penetra nos quadros de significância utilizados pelos atores leigos para constituir e reconstituir o mundo social, como também incorpora termos e marcos de referência dos atores sociais para a construção do seu vocabulário técnico das ciências sociais. De uma maneira similar, a própria linguagem técnica das ciências sociais interfere no mundo leigo, modificando o mundo social que espera descrever. Segundo o sociólogo inglês,

Da mesma maneira que os cientistas sociais adotam termos diários - 'significado', 'motivo,' 'poder' etc. - e os utilizam em sentido especificado, assim também os atores leigos tendem a tomar conceitos e teorias das ciências sociais e incorporá-los como elementos constitutivos da racionalização de sua própria conduta. (GIDDENS, 1978, pp. 167-8).

No caso da questão social urbana do Rio de Janeiro e de Santiago do Chile e, mais especificamente, dos movimentos que animaram as lutas populares nessas duas cidades latino-americanas, a compreensão negativa que dessas ações fizeram as teorias da modernização e da marginalidade, a partir da segunda metade do século XX, influenciou o processo de afirmação dos próprios movimentos. De certa maneira, os movimentos de pobladores e de favelados debutam na esfera pública com um discurso que buscava desconstruir o estereótipo dos marginais anômicos elaborado pe- 
las ciências sociais. No caso da Población La Victoria, em Santiago do Chile, cuja tomada de terrenos, realizada em 1957, é sindicada como o marco de início do movimento de pobladores (ESPINOZA, 1988; GARCÉS, 2002), as palavras da principal liderança da tomada, Juan Costa, são esclarecedoras para mostrar o esforço de "limpeza simbólica" (SILVA, 2008) dos pobladores em relação ao estigma de callamperos:

Sabemos perfeitamente que ganharemos para demonstrar ao Chile inteiro que não merecemos o nome de Población 'Callam$p a$, com qual, de maneira humilhante e desrespeitosa muitos cidadãos que não conhecem a miséria e o grave problema habitacional que acontece no mundo, se permitem nos motejar. ( $\mathrm{La} \mathrm{Voz}$ de La Victoria, 16 de noviembre 1958. Año 1, n. ${ }^{\circ} 1$ ).

Em um sentido similar, na gênese do Movimento de Favelados carioca, atribuída à organização do Morro de Borel, e que posteriormente significou a fundação da União de Trabalhadores Favelados, ocorreu um processo bastante próximo, mas mediante a afirmação da condição de trabalhadores em oposição à ideia de vagabundos e bandidos com a qual as populações faveladas eram identificadas na mídia, nas políticas públicas e, em certa medida, na academia (GOMES, 1980; LIMA, 1989).

Voltando ao já citado Anthony Giddens (1978, p. 171),

Há um 'desvio' contínuo dos conceitos construídos pela sociologia, através do que eles são apropriados por aqueles cuja conduta eles foram originariamente cunhados para analisar, e dessa maneira tendem a se tornar características integrantes desta conduta (e por isso, de fato, comprometendo potencialmente a sua utilização original dentro do vocabulário técnico da ciência social). 
Talvez o exemplo mais claro para fazer gráfico desse "desvio" seja a apropriação que atualmente os movimentos sociais urbanos estão fazendo do conceito de "direito à cidade" de Lefebvre (LEFEBVRE, 2010), noção que aparece recorrentemente nos discursos, programas e ações políticos de diversos movimentos nas urbes latino-americanas e que é visto por diferentes autores como uma oportunidade de renovação da teoria e prática desses tipos de movimentos (BURGOS, 2012; HARVEY, 2008; SABATINI; WORMALD, 2004). Ainda mais se considerarmos a postergação que este autor sofreu nas ciências sociais latino-americanas, principalmente pela influência de Manuel Castells, cuja Questão Urbana foi redigida tendo como um dos principais alvos da sua crítica precisamente a obra de Lefebvre.

No sentido inverso da influência, em mais de uma ocasião, as ciências sociais recolheram dos movimentos de pobladores e favelados elementos, categorias e noções para a construção de suas teorias. Talvez o exemplo mais evidente seja a incorporação na Teoria dos Movimentos Sociais Urbanos de uma série de conceitos mobilizados pelo radicalizado movimento de pobladores durante o breve período do governo Allende (1970-73). A radicalização dos pobladores provocou uma radicalização da teoria que os descrevia. A empolgação das ciências sociais com a afirmação dos pobladores de que a tomada do sítio invadido era o primeiro passo para a tomada do poder levou pesquisadores a buscarem desvendar o papel deste novo sujeito na renovação da luta de classes e na construção de uma nova sociedade.

Enfatizar a dimensão performativa das ciências sociais em sua relação com os movimentos estudados, ou seja, a capacidade da ciência para produzir tanto fatos científicos como sociais, moldando a realidade e incidindo nas interpretações cotidianas e na própria construção do sujeito que busca compreender (RAMOS, 2012), não implica desconhecer o papel que outros atores podem ter no processo de emergência e reconhecimento de um movimen- 
to social como o dos pobladores ou favelados. Aliás, a trajetória de ambos os movimentos é inseparável das contribuições de agentes externos a eles, tais como as igrejas (principalmente Católica), os Partidos Políticos, as organizações não governamentais (ONGs) e o próprio Estado. Assim, esta ênfase performática da ciência social na construção dos movimentos sociais em questão supõe assumir o caráter heterônomo do movimento de pobladores e de favelados. Isto quer dizer que os movimentos não surgem de maneira autorreferida como se sua trajetória se fizesse isolada do resto da sociedade.

As ciências cumprem um papel mediador sobre os movimentos sociais em relação à sociedade, mas não de determinação. Logo, os movimentos de pobladores e favelados não são uma "invenção" das ciências sociais, no sentido empregado por Lícia do Prado Valladares (2005) para definir o papel das ciências sociais na criação da questão "favela". Certamente, o movimento de pobladores e o de favelados é obra dos próprios pobladores e favelados. Não pretendo, portanto, nem subestimar sua importância orgânica no movimento, nem sobrestimar a função das ciências sociais na sua formação. Apenas buscarei assinalar que, embora protagonistas da sua própria história, pobladores e favelados contaram com a colaboração ou obstáculo das ciências sociais para o reconhecimento e consolidação de ambos os movimentos. As ciências sociais aparecem, assim, como coprodutoras dos movimentos sociais que buscam analisar. Seguindo Pierre Bourdieu (1999), as ciências sociais formam parte das lutas que descrevem. A construção teórica dos movimentos em questão não é um processo neutro nem alheio às disputas, divergências e contradições que os constituem. Aliás, é precisamente através da reconstrução do papel das ciências sociais na constituição dos movimentos que espero iluminar aspectos até agora desconsiderados na trajetória desses movimentos sociais.

Será mediante a revisão crítica da literatura elaborada pelas ciências sociais, durante a segunda metade do século XX, sobre a 
questão social urbana no Rio de Janeiro e em Santiago do Chile, que espero mostrar seu papel na coprodução dos movimentos de favelados e de pobladores nessas cidades. Espera-se que, através da reconstrução das polêmicas, da descrição das principais teorias e da análise dos principais intérpretes da questão social urbana, seja possível contribuir à melhor compreensão dos pobres urbanos que encontraram um lugar tanto nas cidades latino-americanas como na história das lutas populares do continente.

A unidade de análise desta pesquisa são as textualidades científicas produzidas a partir da segunda metade do século XX até os anos 1990: artigos, livros e, em menor medida, teses e documentos de trabalho ${ }^{2}$. A seleção desses textos se deu primeiro graças à consulta de obras canônicas na área, o que permitiu reconstruir a bibliografia do período a partir das citações mais recorrentes. Também foram consultados repositórios institucionais de alguns dos centros que pesquisaram com maior atenção à questão urbana (FLACSO, SUR, CEBRAP, EURE etc.). Além disso, foi inestimável o acesso ao arquivo privado do professor Luiz Antônio Machado sobre a literatura brasileira a respeito do tema, assim como a ajuda da obra de Valladares e Medeiros (2003), autoras que sistematizaram toda a produção já feita sobre Favelas entre 1906 e 2000. Embora não exista um esforço análogo no Chile (VALLADARES e COELHO, 1996), o acesso à Biblioteca da PUC-Chile, uma das mais completas na área de pobladores, graças à gestão do professor Gonzalo Cáceres do Instituto de Estudios Urbanos y Territoriales dessa universidade, assim como suas próprias indicações bibliográficas, foram fundamentais para a conformação da amostra de textualidades aqui analisadas. Embora a seleção de obras não pretendesse ser exaustiva, foi possível reconstruir o mais relevante

2 Trabalhou-se com uma base de cerca de 250 publicações. Para o cálculo desse número foram excluídos textos que, embora citados nesta tese, não correspondem a uma publicação científica do campo de estudos da questão social urbana no Brasil e no Chile no período estudado. 
do debate do campo da questão urbana de Santiago e do Rio de Janeiro.

Por que apenas as textualidades e não outras unidades? Um caminho válido de reconstrução dos campos de estudos de favelados epobladores teria sido também tomar como unidade os pesquisadores. Porém, desconsiderei trabalhar com eles (por exemplo, através de entrevistas), porque considero que as textualidades já têm muito o que dizer por si só, mas também por minha preocupação de que a realização de entrevistas com os autores terminasse por provocar um viés geracional na amostra final, por razões próprias da idade dos implicados, como também pelo temor de que esta reconstrução se fizesse com os filtros dos debates atuais, o que poderia nos levar a uma ilusão biográfica (BOURDIEU, 2006) e bibliográfica. Ou seja, uma apresentação de trajetórias intelectuais e das produções associadas como projetos originários coerentes e lineares, uma sorte de discurso oficial sobre si e sobre sua própria obra intelectual. Embora sejam totalmente válidos outros caminhos de pesquisa para este objeto, resulta indispensável a análise crítica da literatura produzida na área como condição prévia desses empreendimentos intelectuais.

Não se pretende aqui reconstruir a trajetória dos movimentos de pobladores e favelados, embora ao longo do texto se estabeleçam diálogos indispensáveis entre a produção das ciências sociais e a história dos movimentos. Não se espera tampouco gerar uma nova leitura desses movimentos, por isso também não optei por tomar como objeto de estudo os próprios pobladores e favelados, pois não pretendia assumir uma postura de busca de uma verdade oculta na autocompreensão que os pobres urbanos fazem de sua ação coletiva. O intuito deste esforço é, a partir do reconhecimento da performatividade das ciências sociais na sua relação com os movimentos, realizar uma autocompreensão das próprias ciências sociais, contribuindo à sua reflexibilidade. 
As ciências sociais, segundo Bourdieu (1999), possuem o privilégio de converter sua própria prática em objeto de estudo, potenciando assim sua reflexibilidade crítica e a lucidez coletiva e individual do campo. Porém, parece que na relação entre ciências sociais e movimentos sociais, apesar da primeira estar ciente de sua performatividade, pois normalmente os pesquisadores se posicionam no termo esquerdo do binômio emancipação/dominação, nem sempre realiza o exercício crítico de pôr em questão seus próprios pressupostos, interesses e práticas na hora de estudar um movimento social. Fazendo das ciências sociais o objeto de estudo desta pesquisa é que espero contribuir também à reflexibilidade crítica das próprias ciências sociais.

Para tanto, o primeiro capítulo será dedicado à compreensão, como antecedente indireto, das tendências de interpretação da "questão social" em ambos os países, pois nelas já se configura uma tendência que também estará presente na especificação urbana da questão social, a saber, o Brasil, com uma classe operária aparentemente convertida em massa de manobra, e o Chile, com uma classe operária ciente do seu papel histórico na transformação da sociedade. O capítulo 2 tratará sobre a aparição da Teoria da Marginalidade, junto com seus principais pressupostos, enquanto primeira tentativa (ainda nebulosa) de reconhecimento político de favelados e pobladores. Os capítulos 3 e 4 serão dedicados respectivamente às escolas que, criticando as teorias da marginalidade, articularam as principais alternativas de compreensão da ação política dos pobres urbanos: movimento classista/radical (Chile) versus um movimento reivindicatório/utilitarista (Rio de Janeiro), respectivamente. No capítulo 5 , se mostrará como as ciências sociais reinterpretaram o movimento de pobladores durante a ditadura sob três signos diferentes: como um movimiento comunitário, como um anti-movimento social e como um movimento orientado à reconstrução popular do espaço urbano. No capítulo 6, se analisará a experiência dos movimentos na década de 1990, 
marcada pela perda de protagonismo social e acadêmico dos pobladores devido à desmobilização e à mudança de agenda das ciências sociais. Finalmente, no capítulo 7, realiza-se um balanço dos principais desafios teóricos à luz da reconstrução do campo da questão social urbana em Santiago e no Rio de Janeiro.

O Chile e o Brasil, como "casos particulares do possível" da questão social urbana, oferecem um amplo conjunto de experiências populares significativas para a compreensão da ação coletiva dos pobres urbanos das cidades da América Latina, contando, ao mesmo tempo, com um denso arcabouço teórico dado pelos diferentes esforços reflexivos que paralelamente se outorgaram a tarefa de estudar estes fenômenos sociais. A relação entre as ciências sociais e seus objetos de estudo não se faz sem tensões, o que é particularmente evidente no caso da questão social urbana da América Latina, tal como assinala Maura Véras (2003, p. 86):

A literatura a respeito dos movimentos sociais urbanos muitas vezes oscilou de um otimismo exagerado (da 'nova modalidade da luta de classes') ao pessimismo ('movimentos simplesmente reivindicatórios, peticionários, pequenos burgueses'); muitas vezes se distinguiu entre o 'morador' e o 'cidadão', ou seja, o primeiro só querendo 'adaptar-se' à cidade do capital e o segundo, tendo consciência real dos direitos e deveres, podendo trabalhar por uma efetiva transformação da sociedade.

Em que medida essas polêmicas e tensões na literatura contribuíram para modelar os movimentos sociais aqui convocados? Como as ciências sociais exercem o papel de coprodutores destes movimentos? Como a compreensão de ambos os movimentos como construçôes teóricas das ciências sociais pode permitir me- 
lhor compreender as trajetórias de pobladores e favelados como atores políticos e sociais? Nos seguintes capítulos, espero contribuir para responder a essas perguntas. 


\section{Capítulo 1 \\ DA QUESTÃO SOCIAL À QUESTÃO \\ SOCIAL URBANA ${ }^{1}$}

Sem a suposição de comparabilidade do Chile e do Brasil, este trabalho não teria sentido. Mas, isso não impede que se considerem, para começar, pelo menos como pano de fundo, algumas diferenças. Em particular e de maneira sucinta, acho relevante marcar que, apesar de ambas as sociedades compartilharem a condição de sociedades dependentes, ou seja, de uma posição subordinada na economia internacional, o processo de conformação e consolidação de seus estados é dissímil.

A prematura consolidação do que no Chile se conheceu como o "estado portaliano"2 (durante o período 1830-1891), caracterizado por um governo forte e centralizador, sustentado na obediência incondicional à autoridade (GÓNGORA, 1981) - a despeito dos questionamentos de uma historiografia mais recente que aponta para vacuidade de legitimidade do sistema estatal chileno (pela ausência da sociedade civil na construção do estado) (SALAZAR et al., 1999) -, indica a estabilidade e solidez de um Estado com uma institucionalidade vigorosa.

1 Uma versão reduzida e adaptada deste capítulo foi publicada como "Além da Dádiva ou da Conquista: as interpretações da questão social no Chile e no Brasil", na Revista Estudos Ibero-Americanos, v. 42, n. ${ }^{\circ} 3$.

2 O conceito faz referência ao triministro chileno Diego Portales, que encarnou a ideia conservadora de um Estado forte e autoritário. 
Isto contrasta com o processo de conformação do Estado brasileiro, pois, tal como assinala Adalberto Cardoso, o Estado (antissocial) brasileiro encontra sua origem "no Império e sua frouxa centralização do poder, que legou à República um Estado que qualifico como um Leviatã de múltiplas cabeças e corpo raquítico, porque incapaz de capilarizar no vasto território nacional" (CARDOSO, 2010a, p. 53). As dimensões continentais do país, os arquipélagos de poder em mãos de oligarquias agrárias locais e os vazios herdados do Império postergaram a articulação do Estado-Nação praticamente até os anos 1930 do século XX (Estado Novo).

Assim, se aceitamos o convite de Das e Poole (2008) para repensar o estado a partir de suas próprias margens - ou seja, se consideramos as margens já não como o espaço de naturalidade (caos, desordem) que enfraquece a forma administrativa de organização política racionalizada que tende a se identificar com o Estado, mas sim como supostos necessários para a configuração e consolidação do próprio Estado - então poderíamos nos aventurar a afirmar que, no caso do Brasil, a relação entre o Estado e suas margens é mais fluida que no caso chileno. Em outras palavras, a construção do Estado brasileiro se realizou com muito maior permeabilidade frente a suas próprias margens. Esse dado será fundamental para entender, por exemplo, a relação do Estado com as favelas (SILVA, 2008).

Porém, se existe um tópico que ilustra os potenciais comparativos dos diálogos entre movimentos sociais e academia no Chile e no Brasil, este é o que se conheceu como a "questão social". Fenômeno eminentemente moderno e conectado com os processos de industrialização e urbanização, tem sido um dos principais tópicos analisados pelas ciências sociais, sendo entendida como uma tomada de consciência da existência de uma fratura central, posta em cena pela multiplicação das descrições do pauperismo, que poderia levar até à dissolução do conjunto da sociedade (CASTEL, 
2004). Estes setores marginalizados, esquecidos pelas classes dirigentes, mas, ao mesmo tempo, temidos e rejeitados, começaram a aumentar com os acelerados processos de urbanização das grandes cidades, provocando que a inicial indiferença da elite se transformasse em medo. A alarmante situação da classe operária obrigou à transformação da relação entre as novas classes trabalhadoras e a própria sociedade. Dessa maneira, a questão social pode ser compreendida como a tentativa de integração social mediante a qual os setores sociais, até então à margem da sociedade, começam a ser incluídos progressivamente através da redefinição de um novo contrato social baseado no trabalho.

Uma das dimensões mais expressivas da questão social foi o problema habitacional das "classes perigosas": a questão urbana aparece atrelada à questão social em geral e só ganhará autonomia analítica quase um século mais tarde. Porém, já em Engels, um dos autores clássicos da teoria social e, além do mais, contemporâneo da emergência da questão social na Europa industrial, estará presente uma reflexão bastante densa do que ele entendeu como "a questão da habitação" (ENGELS, 1979). Para o principal parceiro de Karl Marx, o rápido processo de industrialização que viviam as cidades europeias era quase inseparável da "penúria habitacional", que os operários e uma parcela da pequena burguesia dessas cidades experimentavam, correspondendo a um dos males menores e secundários, originados pelo modo de produção capitalista. Embora, para Engels, essa penúria não seja consequência direta da exploração do trabalhador como tal pelo capitalismo, o autor alemão considera o proletariado como o principal atingido (não o único) da especulação que gerava escassez de habitação, salientando que a crise por falta de alojamento era consequência do modo de produção capitalista.

Uma sociedade não pode existir sem problemas de habitação quando a grande massa de trabalhadores dispóe apenas do seu sa- 
lário, isto é, da soma dos meios indispensáveis à sua subsistência e à sua reprodução; quando os melhoramentos mecânicos deixam massas de operários sem trabalho; quando violentas e cíclicas crises industriais determinam, por um lado, a existência de um grande exército de reserva de desempregados, e por outro lado, atiram periodicamente à rua volumosa massa de trabalhadores; quando os proletários se amontoam nas grandes cidades, e isso se dá num ritmo mais rápido que a construção de habitações nas circunstâncias atuais, e se encontram sempre inquilinos para a mais infeta das pocilgas; quando, enfim, o proprietário de uma casa, na sua qualidade de capitalista, tem não só o direito mas também, em certa medida, graças à concorrência, o dever de exigir, sem escrúpulos, aluguéis elevados. Em semelhante sociedade a crise da habitação não é um acaso mas uma instituição necessária; não pode ser eliminada com modificações a nível de saúde pública etc. porém sim quando toda a ordem social que a originou for transformada pela raiz. (ENGELS, 1979, p. 24).

No Chile, a questão habitacional será considerada como um dos principais problemas sociais durante a maior parte do século XX. O principal organizador do movimento operário chileno, Luis Emilio Recabarren, já alertava, em 1910, sobre o obstáculo moral que representavam os cortiços para o avanço da própria classe operária e os mostrará como uma forma de habitação não menos degradada que a vida no presídio (RECABARREN, 2010). No Brasil, especificamente no Rio de Janeiro, tanto os cortiços como as favelas eram concebidos como as expressões mais visíveis e dramáticas da questão social. Os debates em torno da favela sintetizam, para alguns autores (FISCHER, 2010), as várias etapas da metamorfose da questão social brasileira, representando um dos principais símbolos de ameaça à coesão social no contexto urbano. Centralidade que ainda mantém, considerando o processo de metropolitização da questão social brasileira: 
As metrópoles estão hoje, portanto, no coração dos dilemas políticos, sociais e econômicos da sociedade brasileira, pois expressam as vertentes mais dramáticas dos efeitos da disjunção entre nação, economia e sociedade, inerentes à nossa condição histórica de subordinação à globalização hegemonizada pelo capital financeiro. Devemos ser capazes de dar uma resposta às ameaças de fragmentação nacional nos planos social e territorial, sem o que nenhuma mudança do rumo da economia estabilizada será possível ou terá sentido. Lembrando Celso Furtado, diríamos com ele que nas metrópoles estão concentrados os processos que interrompem a nossa construção como nação, uma vez que nelas estão ocorrendo vários lances do jogo que está decidindo o nosso futuro como sociedade. (RIBEIRO e SANTOS JUNIOR, 2007, pp. 12-3).

Porém, não é a relação direta entre questão social e questão urbana o que interessa especificamente neste capítulo, mas sim as diferentes interpretações que foram elaboradas em torno deste fenômeno no Chile e no Brasil.

Efetivamente, com diferentes intensidades, graus de industrialização e urbanização, assim como com díspares níveis organizativos por parte das classes subalternas que emergiam no cenário social, as distintas sociedades fizeram frente à questão social. De fato, na América Latina, a nova definição da relação salarial nunca significou uma solução generalizada dos problemas sociais, ficando grandes setores do mundo popular marginados dos benefícios dos sistemas de proteção, o que no Brasil conheceu-se, entre outras formulações, como "Cidadania Regulada” (SANTOS, 1998b). Assim, o "Estado de Compromisso" na América Latina nunca alcançou os níveis dos dispositivos de proteção social próprios da Europa, dando à "questão social" um caráter particular no nosso continente. 
Esta especificidade da questão social latino-americana, por sua vez, foi replicada localmente pelos analistas dos países latino-americanos, contribuindo à conformação de mitos e interpretações nacionais da questão social que, embora reconheçam o destino comum das economias periféricas e de industrialização tardia e incompleta, muitas vezes ignoraram os traços compartidos, enfatizando as suas particularidades por contraposição com o Estado de Bem-Estar e com a classe operária europeia e não fazendo o exercício comparativo com realidades mais parecidas, como as do mesmo continente, salvo notáveis exceções (COLLIER e COLLIER, 1991).

Nesse sentido, os casos do Chile e do Brasil resultam paradigmáticos, já que representam polos opostos das interpretações locais clássicas sobre a questão social. Enquanto no Chile a questão social é interpretada como uma tomada de consciência da classe operária, a qual, produto da sua maturidade política e organizativa, pressiona a classe hegemônica, através de greves e da luta eleitoral, conquistando a legislação social; no Brasil, a interpretação clássica é diametralmente oposta. Assim, a legislação social aparece não como produto da luta da classe operária, mas como uma "dádiva” do Governo de Getúlio Vargas e do Estado Corporativista, uma vez que o próprio sindicato seria uma consequência, e não uma causa dessa legislação.

Da mesma maneira que se interpreta o papel da classe operária nos dois países como exemplos opostos - de passividade, no caso brasileiro; de protagonismo, no chileno, ou seja, de uma classe "manipulada" ou "consciente", respectivamente -, encontramos um correlato na atribuição que tem o Estado no enfrentamento e resolução (parcial) da questão social. Assim, parece haver um consenso em torno à ideia de que, se no Chile as classes dirigentes e o sistema político se viram "ultrapassadas" pelo vigor e capacidade do mundo popular (especial da classe operária), no caso do Brasil, foi o Estado quem "presenteou" a legislação social ao povo, sendo 
o sindicalismo um produto da ação organizadora e coesiva do próprio Estado.

Os dois casos que serão analisados neste capítulo e que, aparentemente, representam faces opostas de uma mesma moeda, resultam úteis para demonstrar como nestes dois países o fenômeno da questão social teve traços comuns que desmistificam as interpretações locais clássicas. Sobretudo, os exemplos do Chile e do Brasil permitirão mostrar que o fenômeno da questão social não é uma resposta unilateral de um setor social determinado, seja a classe operária ou o Estado (e a sua classe hegemônica), mas sim um processo muito mais amplo de reflexibilidade da sociedade, no qual esta toma consciência da necessidade de refundar um pacto social que permita dar-lhe continuidade, mediante a integração de setores sociais antes marginalizados que, pelas condições extremas de miséria, começavam a dar mostras mais ou menos conscientes de rebeldia, questionando a ordem imperante. Assim, o fenômeno não pode ser reduzido a um assunto de "conquista" da classe operária ou de "dádiva" estatal.

A reflexibilidade da "questão social" é também uma contestação "preventiva", pelo fato de compreender que o estado de miséria da classe operária precisa mudar para assegurar a persistência da sociedade (MASSARDO, 2008), bem como reconhecer a potencialidade das classes subalternas para construir hipoteticamente um discurso e projeto contra hegemônicos, precisamente pela existência paupérrima dos seus integrantes. Assim, é possível falar que a resposta à questão social no Chile e no Brasil é também uma reação preventiva, destinada a antecipar as fraturas sociais possíveis da ação organizada das classes populares. Dessa maneira, o papel da classe operaria é determinante, seja pela ameaça real que poderia representar ou pela ameaça potencial de sua organização autônoma.

Revisitar criticamente as interpretações clássicas da questão social nestes dois países é um exercício que também permite apro- 
ximar-se privilegiadamente ao tópico de como as ciências sociais formam parte das lutas que elas mesmas descrevem. Para tanto, se mostrará como essas interpretações visavam legitimar um discurso político no momento em que eram enunciadas, transformando o passado num objeto de disputa do movimento operário. A partir desta revisão espero depreender algumas lições úteis para a compreensão da questão social urbana e seus intérpretes no Rio de Janeiro e Santiago do Chile no processo de construção teórica dos movimentos de favelados e pobladores, respectivamente, pois, como será visto, existe uma tendência na interpretação da questão social nestes dois países que aparecerá com novas roupagens na questão social urbana de Santiago do Chile e do Rio de Janeiro.

\section{Os mitos locais clássicos de interpretação da questão social}

\section{A Dádiva Brasileira}

O enfrentamento da questão social na literatura clássica brasileira explica-se mais pelo protagonismo da figura do Presidente Getúlio Vargas e o seu projeto de Estado Corporativista que pela ação de uma classe trabalhadora ativa e com capacidade de pressão.

É o Estado Corporativista o marco para compreender a emergência da ideia de que a questão social foi, a partir da Revolução de 1930, uma política de Estado e não uma conquista das massas trabalhadoras, hipótese que começa a se configurar já antes da profissionalização das ciências sociais, na pena de um dos mais brilhantes "intelectuais orgânicos" do governo Vargas, a saber, Oliveira Vianna (1951, p. 11):

Coube à Revolução de 1930 o mérito insigne de elevar a questão social - até então relegada à jurisdição da polícia nas correrias da praça pública - à dignidade de um problema fundamental de 
Estado a dar-lhe - como solução um conjunto de leis, em cujos preceitos domina, com um profundo senso de justiça social, um alto espírito de harmonia e colaboração.

Para Vianna, o Brasil em particular não tinha nenhuma tradição de luta de classes e, nesse mesmo sentido, os conflitos sociais, pautados pela relação capital-trabalho, não tinham a intensidade, violência e dramaticidade próprias da Europa, uma vez que o país era idealizado como o possuidor de um destino que entregou bens em excesso para distribuir com todos, e as massas trabalhadoras seriam um grupo sem organização, solidariedade ou partido. Assim, nessa visão, é o Estado quem toma as massas trabalhadoras sob sua proteção, abandonando a atitude de abstenção e imparcialidade que o teria caracterizado antes de 1930. Inspirado na encíclica Rerum Novarum, o que o Estado pretendia era restaurar a dignidade humana do trabalhador, mediante a organização de um sistema de instituições sociais que visava à elevação e à dignificação do trabalhador. Assim, o trabalhador industrial brasileiro conheceria por todas as partes "o carinho do Estado e ação vigilante da sua tutela ou da sua assistência" (VIANNA, 1951, p. 69).

O desenvolvimento do Estado Novo brasileiro, notadamente entre 1945-64, coincide também com a consolidação das modernas ciências sociais brasileiras na segunda metade do século XX, que encontraram, em São Paulo, berço da industrialização local, seu principal espaço de articulação (a Universidade de São Paulo e a Escola Livre). A compreensão do fenômeno populista e as potencialidades da classe operária para a mudança social foram dois dos grandes eixos de reflexão de um grupo de pesquisadores paulistas que consolidou uma interpretação divisora de águas do campo. Porém, este exercício de teorização crítica do populismo varguista foi inseparável da tentativa de superação política do fenômeno que estava sendo estudado. 
$\mathrm{Na}$ hora de caracterizar o governo Vargas, esses autores destacaram o seu caráter autoritário e compreenderam a subordinação da classe trabalhadora urbana como o principal desdobramento desse traço. Tal como assinala um dos seus mais destacados intérpretes:

[... a Legislação Trabalhista e a criação da Previdência Social garantiam amplo apoio popular e operário ao governo Vargas, ao mesmo tempo que "roubaram a práxis proletária" dos anos anteriores, não só fazendo com que as garantias conseguidas pelos trabalhadores aparecessem como uma outorga de cunho paternalista feita pelo Estado aos operários, como transformando, de fato, o movimento operário num tipo de ação perfeitamente enquadrada na esfera racionalizada da atividade social (CARDOSO, 1962, p. 114).

Dessa maneira, a Revolução de 1930 é definida como a inauguração de um processo sistemático de organização oficial do movimento sindical, normatizando-o e disciplinando legalmente a "práxis proletária", passando o sindicalismo a ser controlado (notadamente entre 1937-45) pelos funcionários do Ministério do Trabalho. Segundo Fernando Henrique Cardoso, a falta de autonomia, juntamente com a imaturidade política dos operários e a inexistência de uma tradição proletária, favoreceram a configuração de um tipo de comportamento político-reivindicatório no qual a classe operária aparece antes como "massa de manobra" que como um setor ciente dos seus interesses.

Para Francisco Weffort (1970), o "sindicalismo populista", implementado depois de 1930, teria criado organizações operárias "artificiais". Consequentemente, até as organizações paralelas ao sindicalismo oficial, promovidas pela esquerda, serviram como complemento à estrutura corporativista. No caso do Brasil, o Partido Comunista (PCB) - principal foco da crítica de Weffort - 
teria se mostrado incapaz de organizar a classe operária de maneira autônoma, na contramão do que aconteceu em outros países da região.

O questionamento da "práxis proletária" chegaria ao ponto de se colocar em discussão a própria existência do movimento operário. Esse é o caso de Alain Touraine (1961), quem argumenta que o movimento operário, por definição, sempre foi associado não apenas à defesa dos seus interesses materiais imediatos (salários), como também à ideia de transformação da sociedade. Pode-se falar então de um movimento operário quando este se deixa manipular passivamente por um projeto corporativista? - pergunta-se o sociólogo francês. No Brasil, a existência de uma forte consciência de mobilidade propiciada pela imigração interna, assim como as características subdesenvolvidas do capitalismo, permitiram que o sindicato fosse menos um instrumento nas mãos da classe operária que a expressão de uma participação indireta e involuntária do poder. Seguindo a argumentação de Touraine, o sindicato se projeta apenas como um distribuidor de serviços (médicos e legais) e principalmente como um meio para que os assalariados resolvam seus problemas materiais, e não como o espaço de construção de um projeto alternativo de sociedade.

A existência de um estatuto padrão que normalizava os sindicatos, o controle econômico e financeiro, dado principalmente pelo imposto sindical, a autorização da intervenção ministerial no sindicato e o controle das eleições sindicais por parte do Ministério vão configurar um cenário pouco propício para uma ação operária autônoma. Theotônio dos Santos (1962, p. 104), por exemplo, caracterizou da seguinte maneira a fase na qual o Estado Novo incorporou a questão social às suas preocupações:

1 - A identificação da política trabalhista com a figura pessoal de Getúlio Vargas, que deu origem ao 'queremismo'; 2 - O controle ministerial e paternalista do movimento operário; 3 - A forma- 
ção de uma 'liderança' sindical - os 'pelegos' - de caráter oportunista e com fins políticos de atendimento de clientela eleitoral a base popular para políticos populistas (Getúlio, João Goulart, Ademar de Barros, Jânio Quadros, Roberto Silveira, etc.); 4 - O afastamento dos sindicatos das bases operárias perdendo-se num jogo ministerialista e de cúpula; 5 - A ausência de formação política da classe operária que a lançará nas mãos de uma liderança populista e que a abandonará, como classe, a sua própria sorte.

Essas interpretações procuravam articular uma crítica radical às perspectivas populistas que dominavam o campo sindical. Ao mesmo tempo, tinham o intuito de criar as condições teóricas de superação tanto do varguismo quanto dos seus principais concorrentes no mundo do trabalho, os comunistas. Os primeiros eram vistos como desvirtuadores do que esses intelectuais consideravam como a "verdadeira" práxis proletária, enquanto os segundos eram subvalorizados por sua (in)capacidade de rivalizar com os primeiros sem simultaneamente legitimar a arquitetura oficial. Se o trabalhismo varguista representava um sindicalismo inautêntico, por subordinado, os comunistas representavam um marxismo desvirtuado, pela sua abdicação prática ante as lógicas trabalhistas. Assim, instrumentos políticos inautênticos (trabalhista e comunista) eram indicadores também de uma classe inautêntica. $\mathrm{O}$ projeto de mudança social propugnado por esses intelectuais, que antagonizava com a herança política varguista, exigia uma ruptura com a trajetória política sindical da classe operária brasileira. Mas seria possível essa quebra sem ao mesmo tempo escurecer a voz dos trabalhadores e seu estatuto de ator político?

O golpe de Estado de 1964, embora marcasse uma crise das lógicas políticas do trabalhismo, exacerbou as dinâmicas corporativistas na relação entre a ditadura e os sindicatos. Ao mesmo tempo, interrompeu a carreira de muitos dos pesquisadores que disputavam o campo de estudos do mundo do trabalho. Isto pos- 
sibilitou uma revisão por parte das ciências sociais dos postulados da "outorga", gerando condições de recepção favoráveis aos autores que contemporaneamente propunham uma interpretação que reivindicava a trajetória do movimento operário. Ao mesmo tempo, este exercício de tematização foi estimulado por um interesse renovado destas disciplinas pelos atores sociais que poderiam ser decisivos na derrubada do regime autoritário.

O autor pioneiro dessa virada foi Azis Simão (1966), quem, capitalizando seu conhecimento direto do sindicalismo brasileiro como jornalista do movimento, defendeu precisamente no ano de 1964 sua tese de livre-docência na USP, na qual realizou uma revisão da legislação social anterior a 1930, mostrando que a preocupação social do Estado brasileiro não começou exclusivamente com Vargas. Outro dos fundadores da sociologia do trabalho no Brasil que aproveitou sua experiência no início da sua trajetória com o mundo do trabalho foi Evaristo de Moraes Filho, quem conheceu por dentro o funcionamento do Ministério do Trabalho em diferentes funções (LOPES et al., 2012). Para Moraes Filho (1978, p. 196), embora o Estado tutelasse e controlasse o livre movimento das associações da classe operária, obstaculizando a autodeterminação administrativa das suas organizações, o sindicalismo não teria sido uma invenção do Estado:

Por este rapidíssimo escorço histórico dos nossos movimentos sociais proletários de antes da primeira Grande Guerra e das leis trabalhistas que foram até então promulgadas, já se pode ver que constitui um exagero e grave ofensa aos trabalhadores brasileiros a constante afirmativa de que nada existiu antes de 1930, que toda a legislação a favor dos operários lhes fora graciosamente outorgada, sem nenhuma luta, nem manifestação expressa dos mesmos de que a desejavam. Justiça seja feita aos grandes idealistas, intelectuais e juristas, que tomaram o partido dos operários; justiça se faça àquelas massas anônimas, que, mesmo sem imposto 
sindical, sem proteções ministerialistas, sem falsos líderes sindicais, apresentavam muito maior consciência de classe do que os atuais sindicatos, presos ao Ministério do Trabalho, sem o menor espírito de iniciativa.

A maior proximidade destes autores, e a de outros como José Albertino Rodrigues (1968), com o movimento sindical e as militâncias de esquerda que agiam no seu interior (comunistas e socialistas), teria sido fundamental para a revisão da ideia da "outorga”. Embora as pesquisas que alimentaram as publicações chaves desses intelectuais tenham sido realizadas na década de 1950 e tivessem trajetórias contemporâneas (embora diferenciadas) aos teóricos da "outorga”, foi apenas na década de 1970 que ecoaram com mais força no campo de estudos do trabalho.

Por um lado, as novas pesquisas mostravam o predomínio das tendências excludentes/repressivas por sobre as assimiladoras do período de predomínio das lógicas varguistas (FAUSTO, 1977); por outro, se resgatava a prática do movimento operário, salientando a capacidade política ativa desse ator para lidar com condições desfavoráveis. Ambas as tendências contradiziam a ideia de uma simples outorga da legislação social vinda unicamente desde cima. A Revolução de 1930 deixava de ser interpretada apenas como o momento de cooptação da classe operária mediante a aceitação passiva das Leis Trabalhistas, e agora marcaria um ponto de revisão da capacidade de agência da classe operária, passando a ser considerada como um componente participante da "mecânica do poder” (PINHEIRO, 1975). Na relação entre o Estado Novo e os sindicatos, operava uma "mão dupla" que implicou uma incorporação real dos trabalhadores à vida política nacional, porém numa situação de subordinação, a qual era interpretada pela ideologia estadonovista sob a lógica da reciprocidade, onde o Estado se situava desde a "dádiva" e os operários retribuíam com lealdade (GOMES, 1988). 
Teoricamente o principal traço dessa virada interpretativa seria a incorporação de perspectivas gramscianas nos marcos de análise do mundo do trabalho. Embora isto permitisse uma releitura que salientava a agência política proletária, complexificando a relação subordinação/autonomia da classe operária no contexto populista (PAOLI et al., 1984), houve, contudo, perspectivas opostas. Por exemplo, Francisco Weffort (1978) reconheceu nas classes populares um sujeito político com capacidade potencial de intervenção e de pressão, relativizando a noção de manipulação tão presente na literatura clássica e no próprio trabalho anterior desse autor - e sugerindo a categoria de "aliança" como mais adequada para entender a relação entre as massas urbanas e os grupos trabalhistas presentes no Estado. Em contraste, Luiz Werneck Vianna (1976) não apenas resgatou a práxis política do Partido Comunista no mundo sindical, como mostrou uma dupla operação varguista tendente a anular esses esforços para consolidar a mitologia estadonovista: por um lado, o espírito de controle que inspirava as Leis Trabalhistas; por outro, a tentativa de supressão da memória das classes subalternas, através da noção de uma classe impotente e incapaz de reivindicar por si própria seus interesses. A aceitação de uma "teoria do pacto", entre o Estado Novo e a classe operária, implicaria a omissão da maciça e brutal repressão aos sindicatos após a organização da Aliança Nacional Libertadora (de influência comunista), assim como a eliminação dos traços liberais da Constituição de 34. Para Werneck Vianna, a "outorga" é real, mas enquanto ideologia; e é resultante não de um pacto, com a classe operária, mas entre as diferentes facções das classes dominantes.

Esse influxo gramsiciano com seus diferentes matizes foi decisivo para preparar um campo favorável nas ciências sociais à explosão das greves operárias paulistas, em 1978, em plena ditadura militar. Estas foram interpretadas como a irrupção de uma classe que, desta vez falando por boca própria, parecia ter superado as 
lógicas de cooptação, enquadramento e controle associadas ao sindicalismo anterior (SADER, 2010), o que renovou o interesse das ciências sociais sobre o papel dos trabalhadores na conformação da sociedade brasileira.

Foi então questionada uma imagem constituída intelectualmente, no interior da qual os trabalhadores eram vistos como subordinados ao Estado graças a determinações estruturais da industrialização brasileira... O que para nós definiu uma ruptura com a produção anterior sobre a classe operária foi a noção de sujeito que emerge dessa nova produção, isto é, o estatuto conferido às práticas dos trabalhadores, como dotadas de sentido, peso político e significado histórico na dinâmica da sociedade (PAOLI et al., 1984, p. 130).

Efetivamente, muitas das dificuldades teóricas sofridas pelos intelectuais que estudaram movimentos sociais e, em particular, o movimento operário até então correspondiam ao não cumprimento das expectativas de comportamento esperadas pelos próprios analistas em relação a como deveriam acontecer as transformações políticas atribuídas a estes atores sociais (DURHAM, 1984). Na conjuntura aberta pela onda de greves no ABC paulista, as ciências sociais recuperaram o interesse pelos atores populares, mas ao mesmo tempo leram sua irrupção numa chave de ineditismo, compreendendo os novos movimentos sociais (nas fábricas e nos bairros) como a corporificação da promessa de mudança de um ator social que, na prática, tinha agido contrariando as expectativas dos seus intérpretes. A busca de uma potencialidade revolucionária ou hiperdemocrática nos movimentos sociais, como foi o caso dos autores que divulgaram a teoria da "dádiva" ou da geração que via nos novos movimentos sociais uma via de saída à ditadura, seria mais o desejo utópico dos analistas do que uma evidência empírica (CARDOSO, 1987). De maneira sintética, o 
redescobrimento do (novo) movimento sindical era inseparável da ruptura com o velho sindicalismo e indiretamente implicava um ressurgimento da interpretação clássica da questão social. Para Marco Aurélio Santana (1998), as querelas da esquerda brasileira no interior do movimento sindical na década de 1980-90 não foram apenas uma batalha para se impor no presente; implicaram também a transformação da história num elemento de disputa. Assim, a emergência de um "novo" sindicalismo brasileiro, no final da década de 1970, significou uma ruptura discursiva com um passado no qual o "velho" movimento transitou nos estreitos limiares da estrutura sindical corporativa, que era apenas uma extensão do jogo de dominação das elites. Estabelecer essa fratura significará, para Santana, ignorar e subestimar os esforços desenvolvidos no interior do sindicalismo pós-varguista para defender os interesses e os direitos dos trabalhadores, omitindo também o constante esforço em prol da democratização dos sindicatos, sempre expostos aos dispositivos de controle do Ministério do Trabalho.

Por outra parte, John French mostrou que a relação entre movimento sindical e as leis trabalhistas foi bem mais complicada e conflituosa do que a literatura clássica mostrou. Aliás, contra os desejos dos corporativistas, a ação do Estado não destruiu os sindicatos nem desmobilizou os trabalhadores; ao contrário, teria contribuído para criação de um espaço utilizado para auto-organização e mobilização dos trabalhadores. Porém, as leis trabalhistas estariam longe de representar um esforço idealista de implementação de um padrão moral de justiça nos locais do trabalho. $\mathrm{Na}$ prática, muitas das promessas contidas nas leis eram letra morta e seu cumprimento era possível só mediante a pressão direta dos sindicalistas sobre os empregadores. Segundo French (2001, p. 73), cientes desta situação, "para sobreviver e lutar no Brasil industrial, os trabalhadores necessitavam de um posicionamento que tanto rejeitasse a lei como a idealizasse". Se Getúlio Vargas era o "pai dos pobres", também era "mãe dos ricos", como ironicamente o mo- 
vimento sindical esquerdista completava a frase de exaltação do líder populista. Vargas, por um lado, criou a legislação social, mas, por outro, não estabeleceu ferramentas eficazes para que esta fosse cumprida. Paradoxalmente, a produção das ciências sociais nos anos 1960 contribuiu à reprodução da ideia de que os objetivos das leis trabalhistas tinham sido realmente alcançados na prática, confundindo as leis com os fatos e, ao mesmo tempo, negligenciando a prática organizacional da classe operária e notadamente sua relação com os patrões: "Concebida como uma crítica radicalmente desmistificadora das mitologias do Estado populista, a interpretação dominante surgida nos últimos anos da década de 1960 refletiu inconscientemente as presunções e afirmações do regime de Getúlio Vargas” (FRENCH, 2001, p. 82).

Como compreender, então, a tentativa varguista de enfrentar a questão social sem subestimar a prática sindical brasileira? Wanderley Guilherme dos Santos (1998) propôs uma nova ruptura no final da década de 1990. Para ele, as Leis do Trabalho buscavam conciliar a política de acumulação do capital e uma política de equidade, assegurando que esta última não ameaçasse o esforço de acumulação e que este não exacerbasse as iniquidades sociais. A Revolução de 1930 representou um esforço de renovação do equipamento ideológico para enfrentar o problema da ordem econômica e social, que, ao manter unicamente a resposta repressora do laissez-faire brasileiro, teria sido condenado à implosão. Dessa maneira, a cidadania ficou atrelada a um restrito número de posições laborais reconhecidas e reguladas pelo poder estatal, a "cidadania regulada".

Todos os trabalhadores não contemplados nas categorias reconhecidas tornaram-se uma espécie de pré-cidadãos. Estes segmentos, incluindo todos os trabalhadores do campo (não contemplados na regulação trabalhista), avultaram, posteriormente, os conceitos de marginalidade e economia informal do trabalho. Numa recente releitura da "cidadania regulada", Adalberto Car- 
doso (2010a) valorou seu papel como promessa de incorporação social das massas operárias até esse momento totalmente postergadas, introduzindo, assim, um horizonte de cidadania fundamental para as expectativas e práticas dos trabalhadores urbanos, que, ao mesmo tempo, foi determinante para a reprodução das desigualdades sociais, enquanto promessa jamais universalizada. Assim:

A 'cidadania regulada', nesse sentido, tornou-se a forma institucional da luta de classes entre nós: uma luta por efetividade dos direitos existentes; uma luta por extensão dos direitos a novas categorias profissionais; e uma luta por novos direitos. Isso quer dizer, ademais, que, se os direitos sociais e do trabalho (e os serviços sociais de saúde e educação) precisaram ganhar facticidade por meio da luta regulada de classes, então a 'cidadania regulada' precisou ser conquistada pelos candidatos a ela, tanto individual quanto coletivamente. Tendo ou não sido outorgada por Vargas (discussão que tantas energias consumiu dos estudiosos do trabalho no Brasil), o fato é que, no processo de tornar-se real no mundo, a legislação social foi apropriada pelos trabalhadores, e a 'cidadania regulada' não era outra coisa senão $o$ modo dessa apropriação em seu processo mais miúdo, mais cotidiano (CARDOSO, 2010b, pp. 792-3).

\section{O caso do Chile: A conquista operária}

No caso do país andino, desde a década de 1950, construiu-se um relato historiográfico sobre a classe operária inverso ao brasileiro. Na interpretação chilena clássica da questão social, o sindicalismo de começos do século XX é visto como um sindicalismo de classe, com um alto grau de independência frente ao Estado e fortemente engajado com a práxis dos partidos classistas. Além do mais, o movimento mostrava lucidez nas suas manifestações em re- 
lação à necessidade de superar a ordem capitalista por um sistema socialista. A construção desse ideário associando o movimento operário a uma imagem heroica, contestatária, consciente, solidária e homogênea é inseparável do papel da historiografia na sua reprodução, correspondendo esse labor aos historiadores marxistas clássicos: Julio César Jobet, Marcelo Segall, Hernán Ramírez Necochea, Jorge Barría, Luis Vitale y Fernando Ortiz Letelier, entre outros (PINTO et al., 1999).

Embora com militâncias diversas dentro do campo do marxismo local, todos esses autores reconheciam a centralidade da luta de classes na conformação da sociedade e, com ela, o protagonismo dos trabalhadores na arena política e historiográfica. Depois de tudo, tratava-se da classe à qual pertencia o porvir (RAMÍREZ NECOCHEA, 2007a, p. 281), que, até esse momento, não contava com historiadores próprios (JOBET, 1951). O que animava esses autores era o interesse político de contribuir ao fortalecimento e projeção desse protagonismo para a consecução do socialismo (ROJAS, 2000). Propondo uma nova relação entre o ofício historiográfico e a militância, o labor do historiador aparece como um complemento e até uma extensão da luta por uma sociedade sem classes (BARRÍA, 1971a). Esta virada teve correspondência com a valoração emancipatória do binômio sindicato-partido como eixo da progressiva maduração da consciência operária (JOBET, 1955). Tratava-se não apenas de uma trajetória linear do movimento operário, mas de uma sincronia entre esta e os processos políticos, articulada graças à relação virtuosa entre o social e o político. O que, para Jorge Barría (1971b), se expressava na trilogia de organizações criadas pelo movimento operário - sindicatos, cooperativas e partidos - para defender seus interesses enquanto produtores, consumidores e cidadãos. Subvalorizando outras expressões, como o peso das organizações e militantes anarcossindicalistas para o desenvolvimento do movimento operário, esta exaltação evolucionista do movimento legitimava ao mesmo tempo o 
partido como o instrumento próprio da classe, ocultando a autoria dessa relação e fazendo com que aparecesse como um produto quase natural (THIELEMANN, 2013).

Sob esta perspectiva, o processo de ampliação da cidadania por parte do Estado chileno, que culminou com a institucionalização de uma série de direitos, longe de ser interpretado como uma dádiva das classes dominantes, foi lido como uma conquista operária propiciada pela ação, consciência e combatividade do próprio proletariado chileno. Vale a pena citar um dos fundadores da historiografia social chilena, Hernán Ramírez Necochea (2007a, p. 287), que, em um texto publicado originalmente, em 1956, expressava em relação a este ponto:

Pois bem, a história do movimento operário ensina que os direitos que hoje desfruta a classe operária e os benefícios que em alguma medida conquistou, não foram gratuitas concessões feitas pelos governantes burgueses ou latifundiários; também não foram dádivas desinteressadas das classes dirigentes. São única e exclusivamente conquistas da classe operária. Ela, através de suas longas lutas, durante as quais fez sacrifícios incontáveis e teve fazer exibição de heroísmo ante a brutal violência desatada na sua contra; ela, regando muitas vezes a terra do Chile com seu sangue generoso e dando exemplos imperecedouros de dignidade, ela e apenas ela, conquistou os direitos e os benefícios - muito escassos ainda - dos quais atualmente desfruta.

O proletariado chileno, desde esta perspectiva, teria encontrado cedo sua maturidade, superando a espontaneidade inicial que o caracterizou mediante um processo de articulação e de conscientização ascendentes. Existiria, ao mesmo tempo, uma continuidade entre a origem e o desenvolvimento do sindicalismo chileno. Segundo Fernando Ortiz Letelier (2005, p. 113), em texto de 1985: 
Os proletários não se resignaram passivamente à sua vida de misérias; buscaram melhorar sua situação, se revelaram contra os que os exploravam. Rebelião espontânea, isolada, individual num começo; greve, movimento coletivo logo, carente ainda de direção e perspectivas, mas onde operários expressavam sua consciência de classe e faziam da sua organização o instrumento eficaz para defender seu porvir, greves nacionais, por último, realizadas num plano mais elevado e que reflete o grau de amadurecimento conseguido pela classe operária. As reivindicações econômicas encontram um curso adequado nas novas ideias políticas, o proletariado compreende que não basta lutar pela reivindicação imediata como também deve modificar, mudar, a estrutura de um regime para terminar definitivamente com sua exploração.

A afirmação da continuidade histórica do movimento operário, dada pelo processo ascendente de lutas e de tomada de consciência, está atrelada com a reivindicação por parte do movimento sindical do passado heroico de sua organização, valorando a gênese do movimento como um elemento inspirador do sindicalismo posterior, o qual estará marcado pela presença socialista-comunista e que será coroado com a conquista do governo com a Unidade Popular de Salvador Allende, em 1970.

Resulta interessante observar que, sob esta matriz de pensamento, os diferentes esforços do Presidente Arturo Alessandri (1920) para enfrentar a questão social - o que o situa como uma espécie de equivalente democrático de Getúlio Vargas - foram interpretados, por esta historiografia, como um simples reformismo burguês que pretendia deter o avanço do movimento operário: 'Um setor dos 'de cima' - elementos burgueses -, que sentiam a impossibilidade de seguir administrando o Estado conforme os padrões existentes, estimavam que era preciso considerar as novas realidades e programar uma política de novo estilo para enfrentar 
uma situação julgada como temível pela carga social explosiva que implicava" (RAMÍREZ NECOCHEA, 2007b, p. 263).

Essas tentativas seriam uma reação à iniciativa e pressão operária, que teria obrigado os setores governantes a se abrirem à possibilidade de uma legislação que incorporasse parte das demandas históricas do movimento operário: "Foi o impulso dos operários, suas lutas, suas organizações as que obrigaram os partidos tradicionais a se preocuparem e se pronunciarem sobre a questão social. Enquanto o movimento operário se fez ameaçante, os programas dos partidos políticos tiveram que acolher as aspirações populares. Oportunismos nos mais, simpatia pelo povo nos menos" (ORTIZ LETELIER, 2005, p. 227).

Na construção desse discurso não se realça a figura de Arturo Alessandri, presidente que aprofundou e sistematizou a legislação social, como foi no caso do Brasil com Vargas. Ao contrário, o protagonismo ficará com o operário tipógrafo Luis Emilio Recabarren, "maestro y guía del pueblo chileno" segundo reza seu epitáfio. Esse operário se transformará numa espécie de mito fundador da história das classes subalternas chilenas (MASSARDO, 2008). Recabarren teria corporificado na sua história individual o trânsito coletivo do movimento operário, e seu lugar, portanto, é claro: “representa uma perfeita e completa síntese da trajetória que percorreu o proletariado desde fins do século XIX até princípios da terceira década deste século" (RAMÍREZ NECOCHEA, 2007b, p. 250). Isto tanto pelo papel de Recabarren na fundação do Partido Obrero Socialista, em 1912 (que posteriormente passará a ser o Partido Comunista), como também pela ação organizativa na $\mathrm{Fe}$ deración Obrera de Chile (F.O.Ch.) e pelo papel de propagandista na imprensa operária.

O exemplo e a lição da atividade de Recabarren residem na sua luta inesgotável em prol da organização do proletariado e por lhe outorgar consciência dos seus direitos e responsabilidades; em 
seu trabalho prático de estruturação política e sindical da classe assalariada; na criação e difusão da imprensa operária; no seu intuito por educar e instruir os seus colegas de trabalho; na sua profunda austeridade e honestidade pessoal, na sua abnegação e idealismo, sua coragem e desinteresse, se perfilando como o mais autêntico precursor do 'homem novo', exigido pelo socialismo para sua autêntica realização. $\mathrm{O}$ seu legado nas ideias sociopolíticas se sintetiza na sua sincera adesão à doutrina e ao programa socialista com o propósito de instaurar um sistema revolucionário democrático, oposto de maneira irredutível às distintas formas de ditadura. Foi um estimulador inesgotável da fórmula de emanicipação dos trabalhadores como obra deles próprios, com o elevado objetivo de dar vida a um governo popular que fizesse efetiva a instauração de igualdade, justiça e liberdade (JOBET, 1955, pp. 8-9).

A interpretação de conquista do movimento operário foi durante muito tempo quase inquestionável. Foi somente com a aparição da "nova" história social chilena durante os anos 1980, depois do Golpe Militar, encabeçada por Gabriel Salazar, que o discurso descrito anteriormente encontrou uma revisão profunda:

Tem-se questionado [à historiografia social clássica] sua incapacidade para reconhecer a diversidade cultural ao interior dos setores populares. Também tem se criticado sua tendência a privilegiar as relações entre os trabalhadores e os partidos de esquerda, fazendo aparecer estes últimos como os verdadeiros e únicos protagonistas da história. Incluso tem se atribuído um viés 'iluminista', no sentido de privilegiar a ação racional-instrumental ou o apego a determinados 'projetos' por sobre uma disposição a reconhecer a um ator popular que não era necessariamente discursivo ou projetista (PINTO et al., 1999, p. 113). 
O movimento popular, num sentido amplo, não teria apresentado nenhum projeto alternativo de construção estatal, pois terminou disciplinado sob o império da Constituição e do Código do Trabalho alessandrista (SALAZAR et al., 1999). Depois da aplicação de reformas sociais, começou um período de refluxo do movimento sindical, reduzindo-se a quantidade de greves e confrontos combativos. A ideia de um movimento operário "puro", completamente independente, não apenas fica questionada, como também difícil de sustentar. A passagem de um Estado excludente a um relativamente mais integrador mediante a legislação social e laboral marcou o início de um grande paradoxo para o movimento sindical, pois, por um lado, o movimento operário efetivamente desbordou a realidade oligárquica através da sua autonomia, dispersão e dinâmicas grevistas; porém, por outro, o enquadramento legal terminou por homogeneizá-lo, beneficiando os sindicatos por sobre outras formas de organização, como as Sociedades de Socorro Mútuo. Esse processo foi acompanhado de fortes doses de repressão. Assim, "terminar com a exclusão lhe significou transitar desde uma autonomia relativa a um grau maior de submissão" (FERNÁNDEZ, 2003, p. 145).

Esta mudança na historiografia tem uma raiz histórica: a quebra democrática produzida pelo golpe de Estado, em 1973, provocou também uma quebra epistemológica dentro da historiografia. O fracasso da Unidade Popular e do movimento operário obrigou à revisão profunda da historiografia social clássica. Agora as ênfases eram menos estruturais e mais culturais: o político-ideológico deixava lugar ao identitário (DEVÉS VALDÉS, 1991). A autoafirmação do "obrerismo ilustrado" implicava também silêncios e exclusões dentro do mundo popular que era preciso superar. Tratava-se agora de reconhecer outros atores sociais fundamentais, "os de baixo": camponeses, pobladores, trabalhadores informais etc. (PINTO, 1998). 
Em um texto publicado originalmente em 1985, Gabriel Salazar (2000) criticou a aplicação mecânica do materialismo histórico que, no seu intuito de totalização analítica, terminou por diluir a história existencial das massas populares na história do capitalismo (SEGALL, 1953). Sua opção historiográfica era a observação dos fatos e dos processos do povo enquanto tal, para além da trilogia militante, partido e sindicato. $\mathrm{O}$ povo seria um impulso vital coletivo solidário e reumanizante, cuja historicidade involucraria "o drama interior da nação", sendo papel da historiografia salientar a sustância social contida nas dinâmicas solidárias dos alienados e no poder histórico que elas possuiriam.

Se o processo histórico é - conforme o sentido comum - a energia social aplicada ao desenvolvimento pleno da natureza humana, ou seja, um processo de humanização permanente, então a 'historicidade significativa' radica principalmente naqueles homens que procuram com maior intensidade e imediatismo sua própria humanização e a dos outros. A pulsão humanizante - que é um dos traços distintivos dos homens de base - se estimula, se acumula e se desenvolve precisamente quando os fatores de alienação incrementam sua pressão. É por isto que a historicidade se concentra progressivamente nas masas alienadas, e se o 'povo' é a 'nação', como a dinâmica à estática e o específico ao geral, então 'o povo' é a parte alienada da nação. $\mathrm{O}$ povo é a parte da nação que detém o poder histórico (SALAZAR, 2000, p. 15).

Sergio Grez critica esta vertente ao propor uma história do "baixo povo" esvaziado de sua ação política. Precisamente sua valoração culturalista de um ser popular em estado natural rejeitará a atividade política como eminentemente alheia, desprezando suas incursões institucionais e reestabelecendo indiretamente a noção do mundo popular como objeto da política das elites: "Da apo- 
logia ao racionalismo, à modernidade, às ideologias da redenção social, aos projetos e vanguardas políticas, tem se passado quase sem nuances à valorização da 'barbárie', do espontâneo, do pré-moderno, irracional e sensual” (GREZ, 2005, p. 21). A redução naturalista do popular presente na nova história social chilena, ao acusar a historiografia marxista clássica de se centrar unicamente no político, teria reduzido também o político a uma definição liberal (ou estatal-institucional), sendo que, por outro lado, o social ficaria minimizado ao aspecto solidário-identitário (DÍAZ, 2014). A politização, quando aparece, o faz de maneira apartidária e maniqueísta: o popular se mistifica num relato romântico e idealizador que terminaria por lhe atribuir uma espécie de identidade transistórica essencializada (LOYOLA, 2012).

Mesmo sendo acusada de propugnar uma história do popular sem a política (GREZ, 2005), a nova história social - pela revalorização dos sujeitos e das subjetividades que implicou - paradoxalmente tem sido uma das mais relevantes referências do grupo de pesquisadores que recentemente vêm revitalizando a historiografia política no Chile (PONCE e PÉREZ, 2013). Contudo, apesar das críticas à historiografia marxista, existia, entre os novos historiadores sociais chilenos, o reconhecimento de que o movimento operário classista existiu e gerou uma cultura operária que dignificou o trabalho e o trabalhador, deixando de ter uma conotação pejorativa e se convertendo num veículo de inserção social e orgulho pessoal, desenvolvendo um forte sentimento de solidariedade interna com fortes graus de hostilidade frente aos patróes.

\section{Historiografia e Movimento Operário: algumas semelhanças}

A revisão das interpretações locais clássicas sobre a questão social no Chile e no Brasil, as quais foram criticadas em ambos os países por uma historiografia mais recente que as acusou de mistificar positiva ou negativamente a trajetória destes movimentos 
operários, mostra que, embora aparentemente os processos obedecessem a particularidades que os separavam em polos opostos, existiam diversos traços comuns nas duas experiências. Características que levam necessariamente a questionar as bases dos mitos historiográficos que, por muito tempo, dominaram a interpretação do que se entendeu por questão social em ambos os países.

No Chile e no Brasil, a emergência da questão social está dada por um antes e um depois identificado com a passagem de um Estado excludente a um Estado que toma consciência da necessidade de incorporar novos sujeitos ao seu horizonte de cidadania. Num primeiro momento, a questão social foi ignorada pelas elites desses países e tratada como uma "questão de polícia”, segundo a expressão de Getúlio Vargas. Assim, as contradições entre Capital e Trabalho eram resolvidas diretamente, sem a intermediação do Estado, com exceção da intervenção policial para apagar greves e perseguir sindicalistas.

Da mesma maneira, se, por um lado, a vida urbana representava uma melhoria em relação às condições das zonas rurais desses países, por outro, as condições de miséria se agravavam para os trabalhadores urbanos. Alguns dos problemas que eles tiveram que enfrentar nessa época foram: desníveis entre salários e custo de vida, inexistência de um salário mínimo, concorrência do trabalho pior remunerado de mulheres e crianças, existência de jornadas extenuantes de trabalho, ausência de contratos com garantias legais para o trabalhador. Foram essas condições as que contribuíram para que a ação e a agitação de elementos conscientes da classe operária encontrassem ouvidos, formando-se paulatinamente um movimento operário bastante heterogêneo em ambos os países. Sociedades de socorro, sociedades de resistência, centros culturais e sindicatos foram aparecendo na cena proletária. Com grande influência estrangeira, embora mais no Brasil que no Chile, o movimento importou, adaptou e disseminou ideias socialistas e anarquistas, sendo estas últimas particularmente fortes no começo 
do século XX. Com certa propensão à espontaneidade, esse movimento praticou a ação direta contra o capital, configurando um nutrido movimento grevista e conseguindo muitas vezes ver cumpridas suas demandas, não obstante a intensa repressão que exercia o Estado para satisfazer os capitalistas locais. Em ambos os países, este período se identificou como a "etapa heroica".

O maior peso que começou a ter a atividade industrial nas sociedades e, com ele, a maior concentração urbana e operária, junto com o aumento dos conflitos trabalhistas, favorecidos por uma maior capacidade organizativa e agitadora da classe operária, com greves gerais incluídas, levaram a que setores reformistas, mais sensíveis à questão social nas classes dirigentes, ganhassem importância nos destinos dos países estudados. Assim, com Alessandri no Chile e com Vargas no Brasil, começa um processo de ampliação, com restrições, da cidadania nas respectivas sociedades; conceitos como progresso nacional e harmonia entre capital e trabalho serão fundamentais e predominarão nos discursos dos setores governantes. $O$ Estado não apenas manterá o seu braço repressivo para intervir quando seja conveniente, como também visará à proteção do trabalhador com o estabelecimento de garantias legais, buscando antecipar conflitos através dos códigos de trabalho respectivos, mas sem esquecer o disciplinamento do movimento operário, enquadrando-o dentro dos sindicatos, os quais substituíram as heterogêneas organizações do período heroico. Em síntese, como gostava de dizer Vargas, a questão social deixou de ser um assunto de polícia para ser um assunto de Estado.

Nessa mudança, está presente um processo reflexivo, com maior ou menor grau de consciência, por parte das classes dirigentes, de que é preciso enfrentar e prevenir-se frente às forças destrutivas que liberou o próprio capitalismo nas suas sociedades. Não se pode esquecer que o lema do movimento que fez a Revolução de 1930, no Brasil, foi: "Façamos a revolução antes que o povo a faça!” (DIAS, 1962, p. 81). Essencialmente, o que se buscava era a 
prevenção de uma possível fratura social. Por isso, as seguintes palavras de Arturo Alessandri, pronunciadas em 1923, poderiam perfeitamente ter sido proferidas por Getulio Vargas nos anos 1930:

Entre nós é indispensável a rápida promulgação de leis que contemplem os interesses de patrões e operários, como um antídoto para os espíritos subversivos que desejam e perseguem a dissolução da ordem social. Estabeleça o equilíbrio social através de leis justas que contemplem as reivindicações do proletariado e deixe que venham os elementos anárquicos e subversivos a predicar e gritar suas teorias; veja como se baterão impotentes contra a justiça social que é paz, que é ordem, equilíbrio e harmonia (RAMÍREZ NECOCHEA, 2007b, p. 267).

Com os esforços de integração dos estados, as classes operárias ficaram na disjuntiva entre aceitar a interferência do Estado nas relações capital/trabalho e a proteção da legislação laboral - a qual incorporou as principais demandas dos trabalhadores de ambos os países - ou rejeitar o novo cenário, lutando unicamente pela mudança radical do regime salarial. Tanto no Chile quanto no Brasil, a situação foi considerada um progresso para a classe. Esta, mesmo assim, tentou continuar com a atividade sindical tal como vinha sendo levada à prática até esse momento. Porém, o novo contexto dificultou a persistência das mesmas lógicas organizativas, já que a melhoria econômica da nova situação implicava enfrentar de uma maneira nova a agitação, porque os dispositivos repressivos do Estado persistiram e os dirigentes sindicais continuaram sendo perseguidos, seus locais interditados e suas imprensas fechadas. A partir desse momento, o movimento sindical não poderá ser compreendido sem a sua relação com o Estado. Por isso, não corresponde aplicar critérios de pureza proletária na hora de analisar a práxis sindical, pois não apenas no Brasil o movimento operário teve que enfrentar a possibilidade de subordinação, como também no Chile 
isto aconteceu com a classe que foi caracterizada quase como sinônimo de independência e consciência proletária na América Latina.

As diferentes mitologias nos dois países responderam também aos vaivéns políticos dos movimentos operários e das historiografias que tentaram compreendê-los. Enquanto no Chile a influência marxista e a força dos partidos socialista e comunista levaram a reivindicar o passado do movimento operário, ignorando suas fraquezas e inconsistências para mostrar a continuidade e a solidez do movimento, no Brasil, a emergência de um "novo" sindicalismo e a força do "mito da dádiva" estabeleceram um profundo abismo entre o sindicalismo heroico e o sindicalismo posterior a 1930, visando à legitimação dos novos quadros sindicais que queriam romper com o populismo e com seus concorrentes mais próximos (o PCB). Porém, isso implicou também desconhecer o valor de resistência do sindicalismo que enfrentou, não sem perseguição e repressão (e heroísmo), a força corporativista. Nesse sentido, o novo sindicalismo tinha como objetivo neutralizar um concorrente no espaço sindical.

No caso do Brasil, é importante salientar que os dispositivos de controle foram mais fortes, principalmente pela força que tinha o imposto sindical, pois sempre implicou uma vinculação com o Ministério do Trabalho. A possibilidade de ressurgimento de um período heroico estava permanentemente em xeque pelo controle estatal. Contudo, a presença de forças de esquerda persistiu, mas estas tiveram que enfrentar um cenário completamente diferente do chileno, pois a ditadura de Vargas tinha melhores ferramentas de controle do sindicalismo do que as que dispunham os governantes no país andino.

Porém, em ambos os casos, o movimento sindical não pôde atuar sem levar em consideração o novo papel integrador do Estado. Ao mesmo tempo, o Estado se redefiniu pela incorporação (parcial) de novas camadas sociais no seu horizonte de cidadania. Tentar explicar o fenômeno da questão social pela ação de um 
setor isolado da sociedade é uma tarefa incompleta. Tal como se mostrou, esse processo responde a uma tendência reflexiva mais ampla presente na sociedade, na qual, de maneira mais ou menos consciente, as classes que dirigem o Estado compreendem que, para assegurar a sobrevivência deste último, deve-se superar a sua condição excludente e integrar esses novos setores. Paralelamente, as classes trabalhadoras urbanas emergem não para acampar na margem da sociedade, mas, pelo contrário, para nela intervir, seja pela sua força real ou potencial, ganhando um estatuto de ator da nova cena pública.

Compreender a questão social como exercício reflexivo dos diferentes atores da sociedade, no qual se redefine o horizonte de cidadania, requer uma abordagem multiagencial para o seu estudo. As literaturas clássicas no Brasil e no Chile já analisaram o fenômeno com um viés estatal ou social (movimento sindical). Por outro lado, esforços reflexivos mais recentes têm mostrado a importância da recepção e de circulação das ideias (liberais no Chile e corporativistas no Brasil) entre as elites dominantes para a construção do "Estado Social" nos respectivos países (LANZARA, 2012). Porém, a tarefa de integração desses diferentes elementos tem como condição prévia a explicitação do papel das ciências sociais na construção dos imaginários associados às diferentes maneiras de enfrentar a questão social e aos atores que a construíram, notadamente a respeito do movimento operário.

As interpretações baseadas nas ideias de passividade/protagonismo das classes subalternas não apenas substancializaram o estatuto do movimento operário como mais ou menos manipuláveis ou combativos, dificultando as possibilidades de compreensão deste ator social com suas virtudes e defeitos e para além das mistificações do seu agir, como ampliaram o ponto cego de observação das ciências sociais em relação aos próprios movimentos sociais. Não se podem compreender estas interpretações sobre o passado 
operário sem considerar o papel dos cientistas sociais nas disputas pela política do presente.

Ao comparar as interpretações clássicas da questão social no Chile e no Brasil, quanto mais elas conduziam à polarização das trajetórias dos movimentos operários respectivos, mais evidente ficava a participação dessas leituras em projetos políticos que precisavam da idealização do movimento operário, no caso do Chile, e da rejeição da práxis sindical, no caso do Brasil. A separação teórica das práticas dos movimentos operários desses países é motivada por uma práxis comum aos teorizadores dos movimentos sociais: a utilização do passado como uma ferramenta de legitimação de um projeto no presente.

Esta rápida e sintética revisão das ideias clássicas da interpretação da questão social permite destacar alguns elementos úteis para a questão urbana. Em primeiro lugar, adverte sobre o perigo de reproduzir o mito da passividade/protagonismo das classes subalternas agora no âmbito urbano: se seguimos o mito, a classe operária chilena aparece como um exemplo de "classe para si" e a brasileira como de "classe em si" (mais perto de "massa em si"). Fazendo uma análise simples, se poderia replicar a mesma lógica aos seus pobres urbanos: os pobladores seriam o exemplo de um movimento social combativo e politicamente ativo, enquanto os favelados (novamente) massa de manobra. A ideia, pelo contrário, é ir além dessa interpretação, uma vez que a compreensão da constituição tanto dos pobladores quanto dos favelados como atores políticos nessas sociedades deve evitar qualquer tentativa de substancializar as classes subalternas como mais ou menos combativas ou mais ou menos manipuláveis. Assim, as diferenças nas trajetórias dos atores não estariam numa maior disposição dos chilenos à organização e à radicalidade (e o contrário para os favelados), e sim nos diferentes processos políticos envolvidos nas disputas nacionais que, em cada país, possibilitaram que um determinado repertório fosse mais bem sucedido que outro. 


\author{
Capítulo 2 \\ FAVELADOS E POBLADORES \\ NAS TEORIAS DA MARGINALIDADE
}

\title{
Fontes teóricas e precursores
}

Diversas teorias, no debate latino-americano, utilizaram a categoria "marginalidade" como variável explicativa fundamental. As diversas ênfases (produtivas, de organização técnica da produção, socioculturais, políticas, demográficas) mostraram que a discussão da marginalidade não pode ser isolada dos supostos relativos aos contrastantes modelos de desenvolvimento que buscavam ser alternativa de compreensão e de superação do subdesenvolvimento (GERMANI, 1973a). Da mesma maneira, enquanto as diferentes teorias vinculavam a marginalidade urbana com a situação do atraso do continente, os programas de intervenção ou as políticas de combate à marginalidade podiam ser consideradas como estratégias de superação do subdesenvolvimento (SABATINI, 1981).

Silva (1971) propôs uma tipologia das principais correntes de interpretação da marginalidade, da qual se depreendem três modelos típicos.

- O primeiro modelo parte dos modos de produção, procurando apreender as repercussões sobre a estrutura de classes. Dentro deste modelo, o processo de acumulação capitalista engendra a formação de um segmento margi- 
nal de trabalhadores sem utilidade para o sistema produtivo. Esse segmento se tornou "disfuncional", devido à concentração monopolística do capital por parte do setor hegemônico em relação ao setor dependente ou subordinado.

- O segundo modelo situa-se analiticamente na "organização técnica da produção", identificando-se dois setores econômicos, um moderno e outro tradicional, o que criaria um desequilíbrio no mercado de trabalho. Como consequência, há a formação de um contingente marginal sub ou não empregado, cujo traço distintivo seria um treinamento profissional inadequado.

- O terceiro estuda as características do processo de modernização, enfatizando os aspectos sócio-culturais, suas inter-relações e mútuas influências sobre os processos econômicos. Assim, o problema principal da marginalidade seria a carência de integração à vida urbana das populações que não obtêm empregos nos setores modernos da economia.

Não obstante a heterogeneidade teórica das perspectivas marginais, elas possuíam como traço comum a leitura de sua disfuncionalidade e, independentemente da matriz ideológica da análise, associavam as camadas marginais com um potencial disruptivo. Isto seja positivamente, por sua capacidade revolucionária, ou negativamente, pelos ônus que representavam para o resto da sociedade. Nesta ideia, está suposta a necessidade de mudanças na sociedade. De caráter revolucionário ou reformista, a mudança social aparece como uma questão provida de urgência (SILVA, 1971).

Em um dos estudos críticos mais completos e, ao mesmo tempo, esquecidos sobre a Teoria da Marginalidade, Jorge Giusti (1973) rastreará a origem conceitual dessas teorias na influência 
dos trabalhos da Escola de Chicago, particularmente na ideia de homem marginal, elaborada por Robert E. Park (1928) e nos estudos pioneiros de Everett Stonequist (1935) sobre a personalidade marginal. Porém, o debate se "latinoamericanizará" de uma maneira bastante diferente às preocupações que animaram os autores de Chicago, adquirindo uma dinâmica e um marco conceitual próprios.

Em 1959, realizou-se em Santiago do Chile uma conferência organizada pela UNESCO sobre os problemas da urbanização na América Latina, na qual participou a maior parte dos mais destacados pesquisadores das nascentes ciências sociais latino-americanas: Herbert Blumer, Gino Germani, Philip Hauser, José Matos Mar, José Medina Echavarría, Juarez Brandão, Andrew Pearse, entre outros (HAUSER, 1962). A realização desta verdadeira cúpula das ciências sociais na América Latina expressou a importância que tinha ganhado a questão da urbanização nas preocupações dos organismos internacionais e dos governos da América Latina. A questão da urbanização era inseparável da questão do desenvolvimento, e era preciso compreendê-la para que não chegasse a se converter num obstáculo para o mesmo. A escolha do cenário não foi menor. Embora não tenha sido uma das áreas que receberam atenção especial no seminário (ao contrário de Buenos Aires, Lima e Rio de Janeiro), a cidade de Santiago, três anos antes, havia sido palco de uma das invasões organizadas de terras urbanas de maior repercussão: a tomada de terrenos da Población La Victoria (CORTÉS, 2008).

A tarefa, segundo foi definida por José Medina Echavarría na publicação posterior organizada por Philip Hauser (1962), era definir as questóes mais importantes para o estudo da urbanização, que permitissem tomar as medidas mais adequadas para resolver os problemas urgentes ou para preveni-los. Além disso, também Medina enxergava uma oportunidade para contribuir ao desenvolvimento das próprias ciências sociais, na medida em que, embora a 
urbanização fosse um fenômeno universal, na América Latina se expressava com tal particularidade que era preciso a elaboração de uma teoria adequada e própria toda vez que as teorias, então em voga, resultavam inaplicáveis nas nossas realidades (Escola de Chicago).

É ilustrativo, neste sentido, o estado do debate latino-americano sobre essa questão crucial. A villa miseria era o diafragma delicado que materializava o momento mais dramático da transição, onde a qualidade temporal que pareceria dar conta acabada da percepção teórica sobre ela, permanecia fixada em espaços inaceitáveis para a percepção tanto política como urbana. O seminário de 1959 em Santiago nos oferece um bom panorama do estado da pesquisa sobre esses temas, que pouco tempo atrás tinham começado a receber atenção analítica das nascentes ciências sociais. É importante se deter nessa fonte, produzida no momento do apogeu do debate Redfield/Lewis, porque se trata de um tema que rapidamente ia entrar num ciclo de enormes mutações, tanto na opinião científica como política. (GORELIK, 2008, p. 78).

Esse seminário deixou também algumas das imagens mais difundidas da questão urbana na América Latina. Particularmente, no caso do Rio de Janeiro, Andrew Pearse (1962) mostrou as favelas cariocas como um mecanismo degradado de integração dos migrantes rurais na cidade. Nesse percurso adaptativo, sobreviviam alguns traços da dependência tipicamente rural, sendo o mais importante a afinidade destes novos urbanitas com o populismo, o qual lhes permitiria manter a lógica paternalista de relações sociais marcadas pela subordinação a um patrão. Descomprometidos com formas de organização extra-familiares (sindicatos, associações de vizinhos) e indiferentes frente à política, a posição de clientela sob a lealdade de algum político populista se estabelece como uma im- 
portante forma de integração dos favelados à vida urbana. Segundo Pearse (1962, p. 202):

O melhor meio de estudar a assimilação cultural dos imigrantes de origem rural consiste em analisar o fenômeno do populismo. No Brasil, o populismo é uma característica dominante da cultura urbana contemporânea. Considerada desde o ponto de vista das classes abastadas e influentes, é um esforço por preservar os privilégios e as autoridades tradicionais ameaçadas pelas instituições democráticas, pela ruptura de vínculos de dependência pessoal que mantinha a estrutura arcaica de relações socioeconômicas no espaço rural, pela independência na incapacidade do trabalhador urbano que nada tem na capital se não seu salário, e pelo desenvolvimento rápido dos meios de comunicação e de instrução que quebram o isolamento social no qual viviam as massas rurais.

O conceito de marginalidade surge na América Latina quando em fins dos anos 1950 começa a se perder o otimismo em relação às virtudes que prometia a industrialização, mediante a substituição de importações. Por isso, chama a atenção que um dos precursores do debate da marginalidade tenha sido a própria Comissão Econômica para América Latina (CEPAL), uma vez que a proposta elaborada por este centro, cujo suporte intelectual foi a obra do economista argentino Raúl Prebisch (GABAY, 2008), marcou uma fase otimista do pensamento desenvolvimentista latino-americano. Segundo a teoria cepalina de desenvolvimento econômico, a dicotomia centro-periferia que marcaria o ordenamento mundial poderia ser superada mediante um processo de "crescimento para dentro" industrializante, pela substituição de importações e pelo abandono da estratégia de crescimento sustentada na exportação de matérias-primas, ou "crescimento para fora" (PREBISCH, 1947). 
Porém, será a própria CEPAL que publicará, em 1964, Problemas Socio-Económicos de la Marginalidad y la Integración Urbana, um estudo do economista Guillermo Rosenblüth em que o conceito aparecerá, de maneira pioneira, como uma categoria central. Nesse texto, que anos depois ganhará uma nova versão, desta vez publicada na Revista Paraguaya de Sociologia (ROSENBLÜTH, 1968), o economista chileno chamará a atenção para o fato de o processo de industrialização não ter sido capaz de absorver a crescente oferta de mão de obra representada pelos grupos marginais e submarginais. Estes últimos, empregando o conceito de cidadania de T.H. Marshall, serão entendidos por Rosenblüth como aqueles grupos de pessoas que possuem certas limitações nos seus direitos reais de cidadania, pelos quais não poderiam participar de forma estável no processo econômico, sendo vedada a possibilidade de mobilidade social ascendente, evidenciando-se diferenças com outros grupos sociais em relação ao trabalho, habitação, saúde, educação e direitos.

Vale destacar que, segundo esta visão, a marginalização dos direitos não seria o produto de um trato segregador e injusto por parte das autoridades, mas sim da escassa preparação cultural desses indivíduos, que desconheceriam boa parte dos direitos dos quais poderiam se beneficiar. Apesar da transferência da responsabilidade da condição de marginalidade aos próprios marginalizados ter sido um traço bastante forte nas vertentes culturalistas das Teorias da Marginalidade, todas elas, incluindo o estudo de Rosenblüth, afirmaram a necessidade de incorporar ao processo produtivo estes enormes conglomerados humanos que seriam uma espécie de população flutuante em torno dos grandes centros urbanos do continente, representando, ao mesmo tempo, o custo social da política econômica seguida tradicionalmente. Aliás, o próprio Rosenblüth notará a estabilidade do fenômeno ao longo do tempo, pelo qual a marginalidade não poderia ser considerada como uma característica transitória. Logo, a marginalidade repre- 
sentaria um obstáculo para o desenvolvimento, pelas dificuldades que suporia incorporar ao processo produtivo grupos sociais que se desempenham em áreas de escassa qualificação e cuja produtividade seria praticamente nula. A marginalidade seria um submundo, por definição, antitético ao desenvolvimento.

A CEPAL (1963), em um estudo sobre O Desenvolvimento Social da América Latina no pós-guerra, redigido por José Medina Echevarría, um dos mais importantes teóricos da sociologia do desenvolvimento na América Latina (MORALES, 2010), falará de "marginalidade da população rural", salientando a existência de um setor baixo do mundo rural não integrado com as instituições do sistema de poder nacional. Os camponeses se relacionariam com o sistema nacional mais como clientela que como cidadãos. No âmbito urbano, será o próprio Raul Prebisch quem, na sua preocupação pelos fatores estruturais externos e internos que entorpeceriam o desenvolvimento econômico e social da América Latina, considerará os moradores de favelas e poblaciones callampas como uma das características do processo de desenvolvimento de nosso continente. Ao mesmo tempo, alertará sobre a gravidade desse fenômeno em duas dimensões: a concentração dessas populações nas cidades e a precariedade de sua existência. Tais elementos poderiam não apenas agravar as tensões sociais, desfavorecendo o investimento privado, mas também gerar um desequilíbrio social eventualmente insuperável para as economias latino-americanas, considerando que a concentração dessas populações se realizaria com uma intensidade superior ao que poderia justificar o desenvolvimento da industrialização desses países.

Para o economista argentino, o problema da marginalidade não se resolveria apenas com a construção de habitações aceitáveis ou com medidas favoráveis a esses grupos, já que tais programas atacariam apenas a manifestação exterior do fenômeno, sendo que a atenção deveria ser posta nos fatores orgânicos dos quais derivaria esse desequilíbrio social. Nas suas próprias palavras, "a solução 
deve-se buscar mais profundamente, no próprio processo de desenvolvimento. Por que vem essa gente às grandes cidades? Pelas mesmas razões que tem se manifestado em todos os países já desenvolvidos. Mas, por que vem em número superior? Por que vem com tanta intensidade?" (PREBISCH, 1963, p. 153). Se a marginalidade é um problema de desenvolvimento, a solução só se pode dar com mais desenvolvimento. Por exemplo, com a tecnificação e capitalização do campo, aumentando os níveis de produtividade e fornecendo vagas de trabalho mais atraentes para a massa de camponeses potencialmente migrantes que pressionam as urbes.

Com a CEPAL, a marginalidade ganha visibilidade como preocupação social, porém o fenômeno deverá esperar a chegada ao organismo internacional do peruano Aníbal Quijano para ser objeto de uma reflexão mais sistemática dentro da instituição. Contudo, a agenda de pesquisa do sociólogo peruano se desenvolverá com independência e, até certo ponto, em concorrência com a produção institucional aqui referida.

Por outro lado, se a CEPAL pautou o ciclo otimista do debate intelectual latino-americano do ponto de vista econômico, foi a Teoria da Modernização de Gino Germani (1971) a que marcou o compasso no campo da sociologia. Além do mais, o fenômeno da marginalidade foi incorporado a uma complexa teoria sobre a mudança social, ganhando substância conceitual.

Gino Germani (1973b), tentou explicar a passagem de uma sociedade tradicional a uma sociedade industrial na América Latina. Para tanto, caracterizou nosso continente como uma sociedade que experimentava fortes e aceleradas transformações, onde o traço fundamental seria a passagem de uma sociedade tradicional a uma moderna. Nessa transição, seria possível a coexistência de formas sociais de épocas diferentes, fenômeno que o autor ítalo-argentino denominou como "dualismo estrutural". Este conceito era entendido como a convivência numa mesma sociedade de duas ou mais formas estruturais (por exemplo, formas tradicionais e 
modernas). O que explicaria este "dualismo estrutural" seria a existência de "assincronias" nos processos de mudança social, ou seja, descompassos, ajustes e atrasos em relação a mudanças esperadas para uma determinada estrutura (BLANCO, 2003; CORTÉS, 2012; DOMINGUES e MANEIRO, 2004).

A marginalidade multidimensional (econômica, social, cultural e política) precisamente é uma das assincronias mais notáveis da modernização na América Latina. Ela, por sua vez, estaria relacionada a outros descompassos: um processo de urbanização mais rápido que o processo de industrialização, um crescimento populacional acelerado (diminuição das taxas de mortalidade e manutenção dos índices de natalidade), persistência de padrões arcaicos na economia (concentração de propriedade no campo) e permanência de descontinuidades internas entre áreas modernizadas/centrais e atrasadas/periféricas, o que fomentaria a migração campo-cidade.

Embora Gino Germani (1973a) tenha publicado um dos textos que virou referência no estudo da marginalidade, El Concepto de Marginalidad: Significado, raices históricas y cuestiones teóricas, con particular referencia a la marginalidad urbana, e conseguido integrar adequadamente o conceito na sua teoria, a marginalidade não ocupava um lugar central na arquitetura teórica germaniana. Contudo, a obra do sociólogo ítalo-argentino (VÁRELA PETITO, 2008) formará parte do marco teórico dos autores que desenvolveram suas perspectivas outorgando à marginalidade a condição de conceito central de seus construtos.

Serão os trabalhos etnográficos realizados em bairros pobres da Cidade do México, durante a década de 1960, pelo antropólogo americano Oscar Lewis (1961 e 1982), os que darão à Teoria da Marginalidade um corpus teórico próprio. Lewis, a partir do estudo de famílias de marginalizados urbanos, desenvolverá o conceito de "Cultura da Pobreza", a qual será entendida como um sistema de vida estável e persistente que é transmitido de geração a geração, 
em que determinados traços de sobrevivência e adaptação popular ao modo de vida urbano se apresentam e modelam de forma peculiar, entre outros: uma luta constante pela vida, desocupação ou subemprego, baixos salários, trabalho infantil, ausência de poupança, alcoolismo, exacerbação da violência como modo de relacionamento e resolução de disputas, prematura iniciação sexual, machismo.

A pobreza aparece aqui não apenas no seu sentido negativo de privação, mas também positivamente pela existência de uma estrutura determinada, segundo Lewis, uma “disposição razoada", assim como pela presença de mecanismos de resistência relativamente estáveis entre os pobres da cidade. Dessa maneira, os marginalizados seriam possuidores de uma subcultura da pobreza com características que podem ser consideradas como soluções locais a problemas que não podem ser resolvidos institucionalmente pelos organismos públicos, seja pela ausência de direitos, pelo custo econômico de acessar determinados benefícios ou pela suspeita que pesaria sobre tudo o que está relacionado com o mundo público e político. Ao mesmo tempo, essa subcultura obstaculizaria a adaptação dos pobres à vida moderna e negaria os caminhos para sair da própria condição de pobreza. A cultura da pobreza seria o principal instrumento para sobreviver à privação e a principal razão de sua não superação.

Agora, quais seriam os portadores dessa cultura? Lewis é enfático ao afirmar que "cultura da pobreza” não é sinônimo de povos primitivos, nem de proletariado ou de camponeses. Para o autor de Hijos de Sánchez, "A cultura da pobreza apenas teria aplicação à gente que está no fundo mesmo da escala socioeconômica, os trabalhadores mais pobres, os camponeses mais pobres, os cultivadores de plantações e essa grande massa heterogênea de pequenos artesãos e comerciantes aos quais em geral se alude como lumpemproletariado" (LEWIS, 1982, p. XV). 
Este setor constituído pela parte mais baixa do povo, embora não possua nada parecido ao que se poderia identificar com algum tipo de consciência de classe, poderia potencialmente ser seduzido por movimentos políticos dirigidos contra a ordem vigente. Efetivamente, os marginalizados seriam críticos aos valores e instituições das classes dominantes, odiariam a polícia, desconfiariam do governo ou de qualquer tipo de autoridade e seriam céticos frente à Igreja. Eis uma das principais preocupações e sentido de urgência do trabalho de Lewis (1982, p. XX), a possibilidade de que essa camada popular transforme sua situação desvantajosa numa motivação política para a transformação radical da sociedade: "nos países menos desenvolvidos do mundo, os que vivem dentro da cultura da pobreza podem se organizar algum dia em um movimento político que busque fundamentalmente mudanças revolucionárias, e esta é uma das razões pelas quais sua existência planteia problemas terrivelmente urgentes".

A forte penetração que as ideias da marginalidade tiveram no mundo político, nas políticas públicas e nos debates intelectuais durante os anos 1960, em parte se explica por este forte tom de advertência. $\mathrm{O}$ mesmo relacionará esses autores com um incipiente movimento social de maneira controvertida. Se por um lado os marginalizados aparecem como carentes de habilidades organizativas e mesmo de qualquer tipo de consciência política, a ideia de marginalidade alimentará um imaginário quase apocalíptico de um lúmpen urbano promotor da disrupção social.

O papel das Teorias da Marginalidade no reconhecimento de um movimento social identificado com os marginalizados será a preocupação das próximas seções deste capítulo. Para tanto, serão analisadas as duas principais vertentes das Teorias da Marginalidade. Elas influenciaram notavelmente a conformação de um campo específico de estudo da ação coletiva dos pobres urbanos da cidade do Rio de Janeiro e de Santiago do Chile, as quais, segundo a distinção mais aceita, podem se dividir entre as perspectivas 
dualistas e o enfoque de polarização. As primeiras considerariam a marginalidade como uma situação própria do processo de transição à modernidade, caracterizado pelo "dualismo estrutural". Autores como o próprio Gino Germani, Oscar Lewis e Roger Vekemans serão classificados como autores dualistas. $\mathrm{O}$ enfoque de polarização ou neo-marxista, segundo a definição de Vekemans (VEKEMANS e SILVA, 1976), assinalará que o crescimento dos setores dinâmicos ou modernos da economia seria as expensas do subdesenvolvimento dos setores atrasados ou tradicionais. A marginalidade seria, portanto, irreversível por ser produto da natureza do modo de produção capitalista de caráter dependente (SABATINI, 1981). Nessa perspectiva, mostra-se ilustrativo o debate entre Nun (2001) e Fernando Henrique Cardoso em torno da ideia de "massa marginal", para dar conta do fenômeno de aumento de populações disfuncionais frente ao regime de produção dominante. Em uma chave similar, Anibal Quijano (1972b) desenvolverá a categoria de "polo marginal" para identificar aquele novo estrato social, secretado por cada setor da economia, que não formaria parte dos setores de sua maior produtividade, não tendo uma função dentro da produção.

\section{A versão dualista da marginalidade}

\section{A leitura cultural do DESAL sobre a marginalidade urbana}

Segundo um artigo publicado no jornal chileno La Nación (10/05/09), em 1959, pouco depois de iniciar seu pontificado, o Papa João XXIII teria afirmado que, antes de finalizar seu período no comando da Igreja Católica, esperava resolver três dúvidas: se os jesuítas eram tão poderosos quanto se dizia, se os franciscanos eram tão pobres quanto se comentava e quem é exatamente Roger Vekemans. Pouco antes de morrer, em 1963, o Papa teria 
confessado a um assessor próximo que, "na verdade, agora sei que os jesuítas não são tão poderosos como se diz, nem os franciscanos tão pobres como se afirma, mas ainda não sei exatamente quem é Roger Vekemans".

Independentemente da veracidade dessa anedota, ela permite apreciar a aura mítica em torno da figura de Roger Vekemans. Esse sociólogo belga e sacerdote jesuíta, fundador da Escola de Sociologia da PUC-Chile, não foi apenas o principal autor de uma das versões mais conhecidas da Teoria da Marginalidade; também foi um influente intelectual no mundo político. Aliás, sua trajetória acadêmica e sua produção teórica são inseparáveis de sua militância na Democracia Cristã chilena (PDC).

Uma medida do impacto da ação político-teórica de Vekemans no Chile foi a publicação do livro Chile Invadido (primeira edição 1968) do jornalista de El Siglo, periódico ligado ao Partido Comunista Chileno (PCCH), Eduardo Labarca (1969). Nesse texto, que causou bastante polêmica no momento de sua aparição, Labarca revisa a história do imperialismo no Chile, mapeando as diversas formas que tomou a intromissão estrangeira na trajetória do país andino. Não deixa de surpreender que o livro dedique um capítulo inteiro a Vekemans, que é apelidado pelo autor como "o homem das mãos de ouro", pela notável capacidade para captar recursos de organizações e governos estrangeiros. $O$ jesuíta é retratado no opúsculo como um agente do imperialismo, acusado até de receber dinheiro da CIA para financiar suas pesquisas.

Depois de sua chegada ao Chile em fevereiro de 1957, Roger Vekemans não demorou em se aproximar do líder de uma jovem Democracia Cristã, Eduardo Frei Montalva. A grande influência que teria possuído sobre Frei foi fundamental para a ascensão do jesuíta nas esferas do poder, o que se capitalizou quando o próprio Frei alcançou a presidência da República em 1964.

Para Labarca, o belga teria se mostrado muito eficiente na hora de levar à prática uma tripla missão: (1) elaborar uma nova 
doutrina social para o PDC em oposição ao marxismo, (2) contribuir ao estabelecimento de um compromisso militante entre a Igreja Católica chilena e o movimento social-cristão e (3) obter apoio político e econômico para o governo de Frei entre os governos ocidentais (Alemanha, EEUU, por exemplo), entre os partidos democrata-cristãos da Europa e o Vaticano. A virtude de Vekemans teria sido transformar sua influência na Igreja e no mundo político e acadêmico em poder. Ele virou o nodo central de uma ampla rede de centros de pesquisa receptores de uma grande quantidade recursos econômicos do exterior.

Não obstante Vekemans tenha assessorado e criado diversas organizações sindicais e acadêmicas, sua principal obra foi a formação do Centro para o Desenvolvimento Econômico e Social da América Latina (DESAL), em outubro de 1960, junto com o professor da Escola de Arquitetura da PUC-Chile Ramón Venegas Carrasco. Foi no DESAL que Vekemans desenvolveu suas principais ideias sobre a marginalidade (BEIGEL, 2011).

No fim do governo de Frei, a influência de Vekemans começou a declinar, e disputas internas dentro da Igreja o transformaram em alvo de inumeráveis críticas pelo caráter monopólico de sua recepção de recursos. Além do mais, a política de Promoção Popular, principal medida para combater a marginalidade e a radicalização dos pobladores, não conseguiu o sucesso esperado, pois a esquerda continuou aumentando sua influência nas poblaciones e rejeitando projetos chaves para a Promoção no parlamento. Esses fatores alimentaram um paulatino distanciamento com o presidente Frei e com a alta hierarquia do PDC. Porém, foi a derrota do candidato desse partido, Radomiro Tomic, nas eleições de 1970, frente ao socialista Salvador Allende, que terminou por selar o destino de Vekemans no Chile. Assim confirmado o triunfo da Unidade Popular (U.P.), Vekemans pegou um voo em direção a Bogotá, o que o condenou a um lento esquecimento. O grau de influência e poder que Roger Vekemans conseguiu ao longo dos anos 
1960 somente são comparáveis à magnitude do silêncio e omissão que agora envolve sua figura.

Porém, a importância da Teoria da Marginalidade para a consolidação de diversas correntes de pensamentos que tentaram refletir sobre a especificidade do desenvolvimento urbano na América Latina foi fundamental (LEZAMA, 2002). Segundo o DESAL, o continente tomou consciência da marginalidade preexistente somente quando se produziu a avalanche sobre as urbes, no momento em que fisicamente foi possível apontar com o dedo os cordões de miséria.

A marginalidade se identifica, segundo esta teoria, com a falta de participação e de pertencimento à sociedade, sendo característica própria da América Latina a dicotomia entre uma sociedade participante, instalada e hegemônica, versus outra sociedade de massas marginais. A marginalidade seria relacional e negativa (carência), já que quando se fala de "falta de participação" se nega a efetividade do vínculo que deveria unir o mundo marginal com a sociedade estabelecida. A marginalidade não seria apenas econômica, mas, sobretudo, cultural, na medida em que afeta todas as esferas da vida social. Essa situação coincidia com uma determinação física, cristalizava-se em um espaço social específico: a favela (ou población). Daí aparecerá a imagem mais forte da marginalidade: “o mundo marginal [...] é um mundo internamente desintegrado, atomizado, um mundo no qual, se existem coagulações, elas serão de tipo ghetto, retraídas sobre si próprias, à defensiva, e não dispostas a se enfrentar com a sociedade estabelecida" (VEKEMANS e SILVA, 1976, p. 81).

$\mathrm{Na}$ sua obra mais tardia sobre a marginalidade e, segundo o próprio Vekemans, mais madura, Marginalidad, Promoción Popular y Neo-Marxismo (1976), o fundador do DESAL tentará dar conta das múltiplas críticas que sua produção intelectual recebeu, mesmo de fogo amigo. Os principais interlocutores com os quais polemizará o jesuíta serão, segundo sua própria terminologia, os 
neo-marxistas José Nun e Aníbal Quijano, salientando a incapacidade desses autores para entender qualquer fenômeno que escape à dicotomia biclassista desde a qual interpretam a América Latina.

No referido texto, Vekemans (1976, p. 15) reconhecerá certa candidez nos seus primeiros trabalhos, mas, ao mesmo tempo, a explicará pela ausência de adversários no campo das ciências sociais. A urgência prática dos seus postulados o teria levado também a um descuido teórico na sua produção. Há nessas justificações um evidente tom de amargura que refletem o declínio de sua própria influência.

Durante mais de uma década nossa equipe se entregou, em corpo e alma, à ação direta. Inteiramente absortos pelos requerimentos da promoção em terreno, não praticávamos senão uma pesquisa de apoio logístico e nosso marco axiológico - a doutrina social da Igreja - ingenuamente o dávamos por descontado e por fundamentalmente indiscutível, como Carta Magna de nosso fazer institucional. O despertar dessa febrilidade ativista foi doloroso. De repente nos encontamos completamente rodeados de hostilidade.

Embora esse texto não tenha experimentado a repercussão esperada, e a maior parte dos críticos da Teoria da Marginalidade do DESAL não apenas o tenham ignorado como continuaram se referindo preferencialmente às publicações originais, resulta indispensável sua revisão para uma compreensão mais completa da proposta de Vekemans. Mais ainda, se considerarmos que os desdobramentos culturalistas da marginalidade levaram o autor a desenvolver uma interpretação da trajetória latino-americana bastante peculiar, na qual a marginalidade remeterá à formação mesma do continente. Em uma virada que o aproxima a uma chave pós-colonialista de análise, Vekemans assumirá uma interpretação que denominará como estrutural-culturalista. 
Para Vekemans, nem o subdesenvolvimento nem a dependência seriam capazes de dar conta do próprio da América Latina. O que é que diferencia nosso continente de outros igualmente subdesenvolvidos e dependentes? A originalidade da América Latina, segundo esse autor, seria que os países não possuiriam uma coesão suficiente para que suas sociedades constituíssem um conjunto, uma totalidade. Seriam, portanto, sociedades in fieri, ou seja, sociedades cartilaginosas em processo de ossificação. A América Latina aparece nessa descrição como uma unidade social que enquanto totalidade estaria em devir. Dessa maneira,

A tese que aqui se propõe é que, dentro da América Latina, se se quer dar conta da 'originalidade' dos seus países, se deve entender que ainda não são nações-Estado concluídas e que, portanto, para captar sua especificidade, é indispensável cruzar a dimensão vertical, própria de toda análise de estratificação, com a horizontalidade de um 'dentro' e um 'afora' internalizado (VEKEMANS e SILVA, 1976, p. 73).

A ruptura entre um setor participante e um marginalizado remeteria à existência de um centro/perifera não apenas no âmbito das relações internacionais, mas também no interior das próprias sociedades. $\mathrm{O}$ ibérico, que se incorporou ao tecido social do continente, manteve, ao longo da história, a exterioridade transatlântica originária em relação ao nativo pré-colombiano e ao africano importado. Este "afora" transatlântico se internalizaria num "adentro" pelas burguesias locais, as quais seriam "herodianas", pois seguiriam vivendo numa matriz cultural externa.

A marginalidade não é, nessa perspectiva, um subproduto da dependência. Esta agravaria a marginalidade, mas não a criaria. É a marginalidade que contribui para gerar a dependência na medida em que a primeira remete à própria formação social do continente iniciada com a colonização ibérica. Daí se depreende 
uma superposição cultural dos diferentes estratos que conformam o continente e que negam a conformação de um "bem comum". Essa separação ficaria mais em evidência com o processo de marginalização urbana.

A marginalidade não se distribuiria da mesma maneira no continente. Naqueles países mais homogêneos culturalmente, onde a presença europeia é mais forte, não apenas existiria menos marginalidade como menores graus de subdesenvolvimento (Argentina ou Uruguai, por exemplo). Segundo Vekemans, a maior densidade de marginalidade corresponde um menor grau de desenvolvimento; e a maior contribuição exógena, menor marginalidade, e consequentemente maior desenvolvimento.

A questão não seria apenas entre um mundo acima e outro abaixo (verticalidade), mas a existência de dois mundos diferentes e separados, cujo possível encontro corre o risco de ser uma confrontação. Segundo Vekemans (1978, p. 92), “América Latina é, assim, um estranho cruzamento entre um mundo que corresponde ao 'clube dos desenvolvidos', e outro que corresponde ao pré-industrial e até ao primitivo". Continuando, em uma referência clara ao dualismo estrutural, o autor afirmará que "encontramos dentro de um mesmo país, província ou cidade, o que se encontra em Londres, Paris ou Nova York e o que, analogicamente falando, subsiste apenas na África e na Ásia”. Ainda na mesma ideia, o autor assinala que a coexistência de padrões de desenvolvimento seria produto desa superposição cultural que caracteriza a América Latina, na qual imagens como a seguinte se reproduziram em todos os seus cantos: "Em metrópoles latino-americanas não são raros os casos em que carros último modelo batem com burros nas ruas cêntricas; ou que, para cruzar uma avenida num bairro residencial de altos ingressos, se tenha que esperar o passo de uma manada de gado".

A marginalidade seria anterior à moderna luta de classes, pois esta se produziria ao interior da sociedade instalada, entre 
capas socais já constituídas: a burguesia e o proletariado. Assim, Vekemans não nega a luta de classes, mas a descarta como fator explicativo da marginalidade. As massas marginalizadas não estariam incorporadas à sociedade, nem como proletariado. "É marginal não apenas o desempregado ou subempregado (no sentido econômico), mas também quem está separado de todas as esferas constitutivas do cultural, e, portanto - ao menos, virtualmente -, de todos os aspectos do viver humano e do atuar social" (VEKEMANS e SILVA, 1976, p. 82). Eis a radicalidade da marginalidade e o que a transforma em algo mais que pobreza.

A linha divisória entre "o instalado" e "o marginal" seria a mesma que separa "participação" e "não participação". O marginalizado não participa da base societária que pode estabelecer a distribuição dos bens e recursos da sociedade, por mais desigual que seja. Ele não participa das decisões que modelam a sociedade, pois está fora das estruturas com as quais a sociedade cria a si própria. Para Vekemans, a falta de coesão interna dos marginalizados impede a utilização do conceito de classe, mas se for preciso o exercício de comparação com alguma categoria marxista para identificar esses setores, ele optará pelo uso da categoria de "lumpemproletariado".

Agora, se a marginalidade não é um fenômeno novo, qual é a importância da multiplicação do fenômeno das barriadas no continente? A chegada dos marginalizados à cidade, tal qual as invasões bárbaras na antiga Roma, mais que inaugurar um novo fenômeno, simplesmente deixa em evidência a ruptura originária que sempre caracterizou a América Latina. Marginalizados sempre existiram, mas com o fenômeno de hiperurbanização latino-americano, eles serão visíveis e próximos, provocando horror nas elites urbanas. Operaria, ao mesmo tempo, um processo de marginalização atrelado às inconsistências da modernização, o que potencializará a marginalidade originária. Os marginalizados antes estavam longe das cidades, mas começaram a se movimentar na sua direção, ocupando os interstícios da urbe com todo tipo de 
conjuntos de habitação precária: tugurios, favelas, cortiços e poblaciones. A marginalidade urbana "é literalmente uma 'emergencia' física; não é criação da marginalidade; é marginalidade que, pelo seu deslocamento ecológico, termina por criar consciência, não apenas na sociedade, que se vê sob o perigo de uma avalanche que a pode soterrar, mas também no próprio marginal" (VEKEMANS e SILVA, 1976, p. 103).

Quando Vekemans e Silva falam de uma consciência no marginalizado, não é por referência a algum tipo de consciência de classe ou política, mas pelo conhecimento do que a vida moderna oferece e que, ao mesmo tempo, é negado a esse excluído. $\mathrm{Na}$ América Latina, com o processo de modernização em curso, teria se produzido uma revolução nas expectativas e aspirações de consumo. $\mathrm{O}$ marginalizado ao migrar à cidade se comportaria, numa comparação bastante pouco afortunada, segundo Vekemans, como uma menina frente a uma vitrine, sem sua carteira e sem alguém que compre por ela. Chama atenção a importância que neste ponto terá o consumo para explicar as consequências negativas da marginalidade. Com a "invasão" à cidade, o marginalizado estaria sob a influência do "efeito demonstração", já que,

Pela primeira vez, o que no começo estava à distância de dois dias e semanas de peregrinação em mula ou burro, hoje é coisa de horas. Alguém que teria vivido toda sua vida descalço sem problemas, quando entra em uma convivência onde o calçado além de ser norma higiénica é norma social, toma consciência de que está caminhando sem sapatos (VEKEMANS e SILVA, 1976, p. 103).

Começa a se configurar com força um dos traços mais notáveis desta teoria: o tom de advertência frente à ameaça dos marginalizados. Vekemans (1969, p. 61) afirma que "a massa marginal se encontra, metaforicamente, frente à vitrine mas sem poder de compra [...] Se passaram quatro séculos e, frente a este novo fato, 
é necessário atuar para que a vitrine não estoure violentamente”.

Por um lado, os marginalizados serão retratados como desprovidos de qualquer tipo de consciência de grupo, pela atomização que os definiria, e como incapazes de gerar por si próprios os mecanismos necessários para sua integração à sociedade, pois séculos de rebaixamento e destruição excluíram o mundo marginal do desenvolvimento da sociedade estabelecida e das ferramentas que esta define para transformá-la; por outro, são pintados como um espectro que ameaça constantemente destruir a ordem das coisas pela sua inclinação para agir como massa de manobra de projetos populistas ou revolucionários.

Para "evitar a destruição da vitrine", o DESAL propunha a Promoção Popular, como tentativa de integração dos marginais a um processo de reestruturação da sociedade. Assim, a noção de promoção poderia se entender como ação "sobre" os marginais (capacitação) e "dos” marginais (organização), sendo o fundamento do processo popular re-integrativo as organizações de base (associações de moradores, centro de mães etc). A ideia era organizar os marginalizados, mediante a entrega de recursos "capacitantes" para unificar suas solidariedades dispersas. Com isso, se pretendia a criação de uma consciência social e de uma estrutura de direitos que permitisse a pressão sobre o Estado.

Quando falamos de promoção, nos referimos à transformação de uma massa marginal em povo, em base societária. Seu sujeito popular 'preferido' o constituem os setores marginais da sociedade (desde os tipos mais puros, como os indígenas, até os mais transicionais, como os subproletários que se filtram na base proletária do sistema de hegemonia), que não pertencem, nem sequer como classe baixa, à rede de estruturas e fundações da sociedade, tal como se dá na atualidade (VEKEMANS e SILVA, 1976, p. 180). 
A teoria do DESAL, como já falado, foi o alvo de inúmeras críticas. Aliás, um grupo importante de pesquisadores na América Latina se formou debatendo e questionando os supostos da marginalidade (GIUSTI, 1973; OLIVEN, 1980; PASTRANA; THRELFALL, 1974; PERLMAN, 1977; SABATINI, 1981). Ao mesmo tempo, variadas pesquisas mostraram que a Teoria do DESAL subestimou o poder integrador da barriada e do movimento dos pobres urbanos. A pobreza urbana se mostrou mais heterogênea do que anunciava a ideia de massa marginal, e os marginalizados encontraram também outras fontes de integração: sindicatos, religião, educação etc. (CIDU, 1972; SABATINI e WORMALD, 2004). Contudo, a Teoria da Marginalidade teve o mérito de transformar os problemas da urbanização popular em um objeto de atenção e de estudo prioritário das ciências sociais do continente. Além do mais, como assinalou Silva (1983), apesar do diagnóstico de sua morte, a teoria continuou viva na prática, pois seu modelo continuou sendo usado nas políticas sociais e nos discursos de atores políticos e meios de comunicação, e os esforços nas ciências sociais para reordenar sistematicamente o problema não foram satisfatórios.

Por outra parte, a difusão da Teoria da Marginalidade do DESAL teve consequências práticas fundamentais para a constituição dos movimentos de pobres urbanos na cidade. Particularmente no Chile, a política de Promoção Popular criou uma estrutura institucional que reconheceu o poblador como um sujeito social e, com a legalização das Juntas de Vecinos (JJ.VV.), se deu corpo a um espírito e organizações já existentes, mas carentes de apoio legal (SILVA TELLO, 1970). E, como se verá mais na frente, terminou por contribuir indiretamente ao reconhecimento do Movimento de Pobladores. 
As ciências sociais sobem o morro: a versão carioca da marginalidade

As Teorias da Marginalidade de inspiração desaliana não apenas impactaram a produção intelectual chilena: seu alcance foi latino-americano. No Brasil, muitas das premissas da marginalidade foram recepcionadas positivamente por grupos de pesquisadores locais, particularmente no Rio de Janeiro. Porém, não existirá um diálogo intertextual entre a produção do DESAL e os brasileiros. Aliás, estes últimos rejeitaram o emprego do conceito de marginal, pelo forte apelo delitivo que tem essa palavra em português.

Contudo, nos pioneiros trabalhos sobre sociologia urbana no Brasil, e particularmente no Rio de Janeiro, se encontrarão elementos similares aos desenvolvidos pelos teóricos da marginalidade. Carlos Alberto Medina (1964), por exemplo, conceberá a favela como um prolongamento do mundo rural na cidade, um tumor rural-primitivo enquistado na moderna metrópole. A favela seria uma erva daninha, mas curável com uma boa administração. Os favelados, ou seja, os habitantes da cidade que ocupam habitações provisórias sem qualquer recurso de saneamento básico, refletindo sua pobreza nas características de sua moradia, não seriam os responsáveis de sua condição desvantajosa.

A favela é um problema produzido e os culpáveis são os demagogos da administração pública, por permitirem os desvios da regulação da vida urbana e por tolerarem, para fins eleitorais, as populações faveladas. O problema era que os favelados, por reproduzirem padrões culturais rurais, eram facilmente manipuláveis por demagogos, o que impedia a possibilidade de encontrar uma solução para sua situação. Os favelados são, segundo Medina, uma população acostumada a baixos padrões de vida material e que habita em espaços onde se reproduz um estilo de vida próprio das camadas mais pobres, o que dificulta sua integração à vida moderna. Logo, é apenas numa administração virtuosa que o problema da favela pode ser resolvido, mas primeiro é preciso que a questão das 
populações faveladas deixe de ser só uma questão de polícia. Essa ideia supõe uma concepção moralizante da vida social e, em particular, da administração de conflitos, visão que será compartilhada por parte importante de Igreja Católica brasileira e por alguns políticos conservadores de inspiração cristã como Carlos Lacerda (1987).

A principal fonte teórica dos autores do que se poderia chamar como "marginalidade carioca", também era de origem cristã. Se, no Chile, a referência central foi o jesuíta Roger Vekemans, no Brasil, esse papel foi encarnado pelo dominicano francês Louis-Joseph Lebret. Ex-oficial da marinha francesa, Lebret foi o fundador do movimento Economia e Humanismo no começo dos anos 1940 do século XX. Segundo Alfredo Bosi (2012), o movimento foi, ao mesmo tempo, uma teoria, um centro de pesquisa e uma revista que inspirou profundamente uma geração de jovens intelectuais católicos, sendo uma das matrizes da passagem, entre 1950 e 1960, de um catolicismo de centro para um cristianismo de esquerda no Brasil. De evidente inspiração reformista, o movimento de Lebret incorporou parcialmente os fundamentos da exploração capitalista de origem marxista, mas propôs uma saída comunitarista, baseada na consolidação de comunidades de base que se apoiariam mutuamente. A reforma da sociedade capitalista só seria possível com a tomada de consciência dos injustiçados e oprimidos da importância de construir uma economia voltada para as necessidades básicas do ser humano em sociedade, as quais não poderiam ser satisfeitas nem pelo puro jogo do mercado nem pelo planejamento central do Estado.

O eco de suas ideias, como já falado, chegou fortemente no terceiro mundo, palco privilegiado da ação de "Economia e $\mathrm{Hu}$ manismo". Lebret chegou a ter uma importante influência sobre as lideranças social-cristãs do continente, incluindo o chileno Eduardo Frei. Suas concepções sobre a degradação do mundo rural e da urbanização patológica da América Latina foram bem difundidas. 
Em boa parte, esta penetração intelectual foi possível pela fundação de organismos locais dependentes de "Economia e Humanismo". Tal foi o caso da Sociedade para a Aplicação do Grafismo e da Mecanografia à Análise de Complexos Sociais (SAGMACS), cuja primeira sede foi fundada em São Paulo. Foi precisamente nessa cidade que Lebret desenvolveu uma série de pesquisas pioneiras sobre urbanização e sobre as condições de habitação das classes populares, isto já na década de 1950. Para Lebret, o lugar onde o pobre morava era o espelho do subdesenvolvimento, logo deveria ser estudado e medido com rigorosidade científica.

O próprio Lebret foi o orientador e articulador da primeira grande pesquisa sobre favelas cariocas, Aspectos Humanos da Favela Carioca (RIOS, 2012). Financiada e publicada pelo jornal paulista Estadão, essa pesquisa, que inaugurará o estudo sistemático das favelas do Rio de Janeiro pelas ciências sociais, foi dirigida tecnicamente por José Arthur Rios, sociólogo de sólida formação metodológica, especializado em sociologia rural, e coordenada pelo já citado Carlos Alberto Medina. Na publicação, se reproduzirão boa parte das ideias até aqui expostas. E como foi assinalado em uma publicação recente que buscou recuperar a importância dessa pesquisa para o campo de estudo das favelas cariocas (MELLO et al., 2012), ela foi produto de vários encontros virtuosos: o de Lebret com Dom Helder Câmara, o grande impulsor da mobilização da Igreja Católica nas favelas, a presença de pesquisadores altamente capacitados em técnicas de pesquisa empírica (quantitativa e qualitativa) e a convergência de duas tradições acadêmicas dissimiles, mas com forte ênfase empírica e urbana: Economia e Humanismo e a Escola de Chicago. A presença de Donald Pierson, antigo aluno de Robert Park, na Escola Livre de Sociologia e Política, em São Paulo, permitirá uma associação inusitada e, segundo Valladares (2012, p. 91), desapercebida pelos estudiosos das favelas cariocas: "O vestígio explícito desse caráter híbrido aparece na própria temática da pesquisa: alguns assuntos estão claramente ligados à 
abordagem típica do Economie et Humanisme, como a moradia, a família, a solidariedade, a escola ou a religião; enquanto temas como a delinquência e os processo políticos (demagogia etc.) foram priorizados pela Escola de Chicago".

A pesquisa buscará alertar os governantes, políticos e estudiosos da questão social sobre o fenômeno das favelas. Elas são concebidas como formas de moradia popular caracterizadas pelo agrupamento desordenado de habitações precárias que se opõem ao traçado regular do centro urbano onde estão inseridas. Neste estudo, se reiterará que a culpa da existência das favelas não é do favelado, pois a responsabilidade seria dos administradores que deveriam estar evitando a sua proliferação mediante o planejamento urbano. "A construção de uma metrópole não é apenas um fenômeno de natureza, mas uma criação consciente. A maneira como o Rio de Janeiro cresceu e as forças sociais e econômicas que nortearam esse crescimento teriam que conduzir necessariamente a uma perda de valores humanos" (RIOS, 1960, p. 8).

A favela é representada como o espaço da desintegração social e moral da cidade. Caracterizada pela miséria, o baixo padrão de vida de seus moradores e a dificuldade de acesso a melhores condições de vida, ela seria o produto da migração rural à cidade. "A favela não subsistiria se não houvesse uma constante migração para a cidade de massas subdesenvolvidas" (RIOS, 1960, p. 11). A migração brasileira para as cidades pode ser vista, nessa perspectiva, como uma fuga de miséria do campo para a cidade, onde ela cumpre a função de ser hospedaria que absorve o excesso de miséria nacional. Ao mesmo tempo, a favela acompanharia o crescimento do Rio de Janeiro como centro manufatureiro, mas ficando em evidência a incapacidade da cidade de absorver a mão de obra expulsa dos campos.

Nesse sentido, a migração campo-cidade estimularia o desenvolvimento de uma "Cultura Cabocla", na qual permanece- 
riam os traços psicológicos e condutas próprias do meio rural, que apareceriam intactos na favela.

Esse migrante troca um tipo de subordinação de traços feudais, onde curte fome e não tem perspectiva nenhuma de acesso social, por qualquer tipo de subserviência, onde tenha assegurado o pão, para si e sua família. Esse migrante, além de trazer consigo dons escassos de técnica, afeito que foi unicamente ao cabo da enxada, carreia para a cidade toda as deficiências sanitárias e educacionais do nosso meio rural: a verminose e o analfabetismo, o pé descalço e o banho de ervas, a superstição e o messianismo. Entre ele e o morador típico da cidade existe a mesma distância cultural que já mediava entre ele e o proprietário da terra que lavrava (RIOS, 1960, p. 9).

A favela é lida como um objeto "exótico" e até exterior à civilidade da vida urbana moderna. Seus habitantes são vistos como carentes de vontade própria ou mesmo de capacidade para reconhecer seus próprios interesses, propensos, portanto, a serem usados como massa de manobra de políticos inescrupulosos. Neste ponto, o tom de advertência é até mais direto que o do DESAL: "É preciso subir o morro antes que deles desçam os comunistas" (RIOS, 1960, p. 43). A criação da Fundação Leão XIII e da Cruzada São Sebastião pela Igreja Católica, em aliança com o governador do Rio de Janeiro Carlos Lacerda, serão a expressão prática de uma nova concepção das populações faveladas, onde se fomenta uma solução em longo prazo: a Promoção Humana dos favelados, o equivalente carioca da política de Promoção Popular do DESAL. Com esses organismos, se estimulará a "participação comunitária" e as organizações de base, essencialmente para se oporem à "exploração demagógica dos políticos" e para, sobretudo, neutralizarem a influência comunista nas favelas. As palavras de D. Helder Câ- 
mara na inauguração do "Congresso Geral dos Representantes das Favelas Cariocas” ( 6 de janeiro de 1957) são claras a esse respeito:

Não estamos numa sessão política ou religiosa. Não somos iguais aos candidatos que aparecem e prometem antes de cada eleição e somem depois, sem cumprir. Somos homens que querem se unir em torno de um ideal, homens católicos, protestantes, espíritas ou lá o que seja, decididos a melhorar de situação a vida de milhares. Eu só tenho medo dos que não acreditam em Deus, dos comunistas. Cuidado, porque para eles quanto mais miséria existir, haverá mais campo a ser explorado (Tribuna da Imprensa, 7/1/57, citado em LIMA, 1989).

D. Helder Câmara, em uma linguagem que reflete o contexto de Guerra Fria, equiparava a disputa entre Oriente e Ocidente com a do mundo superdesenvolvido versus uma massa subdesenvolvida deixada à margem da vida.

A grande habilidade do comunismo vem sendo levantar a massa subdesenvolvida, que será invencível e assegurará a vitória ao lado para onde pender: bandeira anticolonialista, embora, a seu modo, escravize, a pretexto de implantar suas famosas Repúblicas populares; bandeira de reforma agrária, que surge como esperança para a massa esmagada dos trabalhadores rurais; bandeira de ódio de classes para os trabalhadores industriais, invencíveis quando arrastarem, nas grandes cidades, a massa do subproletariado que se aglomera nas favelas (CÂMARA, s.d., p. 2).

A população favelada é tão inocente em relação a sua situação, como perigosa pelas consequências políticas que sua ação pode ter. Eis a urgência de enfrentar o problema das favelas cariocas: elas ameaçam o progresso social futuro e paralelamente representam a negação do mesmo no presente. Segundo a SAGMACS: 
A favela não é apenas uma mancha na tela esplêndida do Rio de Janeiro; é um documento de incapacidade administrativa e de insensibilidade moral. A presença desses amontoados de casebres, onde se comprimem famílias, às vezes numerosas, atesta, mais que um retardamento técnico, uma imaturidade moral. O aglomerado urbano onde tal situação existe não é uma cidade, mas um espaço onde comprimem grupos em luta. Por isso, a solução do problema, mais que qualquer meta desenvolvimentista, representa um atestado de civilização (RIOS, 1960, p. 45).

O forte apelo político preventivo do estudo da SAGMACS não era casual; aliás, as disputas políticas da época favoreceram fortemente a realização do estudo. Tal como explica o próprio Rios (2012, p. 36) em uma avaliação realizada meio século depois da publicação desta obra:

Vivia-se o período esperançoso do presidente Juscelino Kubitscheck que pretendia encurtar o tempo histórico, fazendo o país avançar 50 anos em 5 e construindo uma nova capital nos páramos desérticos do Planalto Central. A ideia enfrentava resistências ferrenhas e um dos centros dessa oposição era, em São Paulo, o jornal conhecido como $O$ Estadão, folha de alta tradição democrática e porta-voz das oposições paulistas. Seu diretor Julio de Mesquita Filho, o 'seu Julinho', lembrou-se de contrastar as aspirações aventureiras de JK com a brutal realidade da então capital federal, expressa nas favelas cariocas. Pensou em Lebret, em SAGMACS.

Para Machado (2012a), o esquecimento que essa obra sofreu no meio acadêmico, apesar de ter sido a pesquisa mais abrangente já realizada sobre favelas cariocas, se explica principalmente por estes vínculos políticos. O financiamento recebido por SAGMACS de setores conservadores transformaram a pesquisa em um instru- 
mento político do jornal paulista no jogo de dominação, passando a ser uma "categoria de luta" no universo de interesses em disputa no Brasil da época, apesar da autonomia acadêmica e metodológica do estudo. Da mesma maneira, a vinculação de Rios com o governo de Carlos Lacerda, mesmo por um curto prazo, teria sido definitiva para que a pesquisa fosse relegada. Exemplificando,

Basta indicar que o termo 'demagogia' continha uma dimensão crítica enquadrada por uma visão processual que pensava na superação do subdesenvolvimento, pacífica e pelos meios institucionais existentes, através do 'desenvolvimento político'. Acontece que na academia esta perspectiva era minoritária, tida como conservadora e 'reformista', o que ajuda a compreender o desinteresse pelo relatório da SAGMACS (SILVA, 2012a, p. 55).

\section{A marginalidade e o reconhecimento negativo de favelados e pobladores como atores politicos}

Existe na ideia de ameaça um potencial reconhecimento da capacidade política dos marginalizados? O caráter preventivo da "subida ao morro" para evitar que "a vitrine se quebre" pode ser comparável à resposta reflexiva da questão social para enfrentar as demandas dos operários? A ideia de "massa de manobra” presente nos autores da marginalidade antagoniza, por definição, com a noção de reconhecimento de atores políticos subalternos. Porém, pode-se reconhecer a possibilidade de fratura da sociedade sem vislumbrar a possibilidade de construção de um projeto político que viabilize essa ruptura?

A noção de "reconhecimento" é um pouco mais clara no caso do movimento operário e não tanto no movimento favelado ou poblacional, embora na ideia de "temos que subir no morro antes que os comunistas desçam" existe um indício, não apenas de 
prevenção e perigo, mas também de potencial conformação de um ator político "radical". Há um medo à massa amorfa, mas o maior medo é à massa que vira classe oprimida radical (ou massa de manobra comunista para eles). $\mathrm{O}$ medo é que a massa amorfa vire um ator político fora dos parâmetros que as classes dominantes pré-definem para as classes subalternas: um marco baseado na ideia de um "bom favelado" que "aprende" a sair da pobreza com as políticas de "Promoção" (Popular ou Humana). Apesar dos preconceitos políticos em relação aos pobres urbanos, estamos frente a um grupo social (dominante) que está considerando um cenário possível, logo esta situação hipotética ("os comunistas descendo") está tendo consequências concretas na realidade e, seguindo o teorema de Thomas, "se os indivíduos definem as situações como reais, elas são reais em suas consequências" (apud MERTON, 1970, p. 515).

Particularmente no caso brasileiro, considero necessário estabelecer uma diferença em relação ao caráter preventivo do agir estatal. Há uma ação sistemática por parte dos setores dominantes para prevenir uma explosão social (a descida do morro) e para neutralizar a influência comunista nas favelas. Porém, se a questão social (operária) passou de ser uma questão de polícia a uma questão de cidadania regulada pelo Estado (em benefício de um pequeno setor dos trabalhadores brasileiros) (SANTOS, 1998), a questão social urbana, em boa parte, continuou sendo uma questão de polícia, e a regulação estatal da cidadania nas favelas foi muito mais contraditória e repressiva que a da fábrica. Em outras palavras, se nos sindicatos o Estado teve um braço esquerdo (legislação laboral) e um direito (controle) fortes, nas favelas se observa uma hipertrofia da extremidade direita, que encontrará na forma das remoções sua melhor expressão. Vale lembrar que até nos contextos favoráveis às favelas a repressão sempre esteve presente nos espaços da pobreza, sendo o rosto mais visível do Estado brasileiro (SILVA, 2005). 


\section{Marginalidade como polarização: a leitura econômico-estrutural}

As diferentes teorias dualistas da marginalidade foram fortemente criticadas no final dos anos 1960, porém houve um grupo de intelectuais que fizeram o questionamento reivindicando o conceito de marginalidade. Essas versões críticas que se situaram em oposição à versão desaliana e outras - tais como a da "cultura da pobreza" de Lewis (1961), e a teoria da modernização de Germani (1971) - realizaram uma leitura materialista da marginalidade, enfatizando a sua dimensão econômica, dialogando com o marxismo e com a Teoria da Dependência.

Não é de estranhar que no fértil debate sociológico latino-americano de finais dos anos 1960 existissem tentativas de desenvolver enfoques totalizantes nos quais se integrassem diversas categorias como desenvolvimento, subdesenvolvimento, dependência, marginalidade e desigualdades espaciais (SUNKEL, 1970). Dentre eles, um dos autores que mais se destacou, por sua sólida síntese entre Marginalidade e Dependência, foi o peruano Aníbal Quijano. Embora seus trabalhos sobre a emergência de um "polo marginal" sejam muito próximos da categoria de "massa marginal", desenvolvida por José Nun (2001), para caracterizar o setor disfuncional da economia capitalista que não pode ser classificado como "exército de reserva", a originalidade de Quijano residirá na importância que outorgará à variável espaço na sua análise (SABATINI, 1981) e a incorporação da arquitetura teórica da dependência à sua própria agenda de pesquisa.

Os debates em torno à dependência marcaram, em relação às teorias da modernização dualistas, uma passagem de explicações endógenas do subdesenvolvimento para a relação com planos e fatores externos, tendência explicativa já aberta pelas contribuições de Prebisch e da CEPAL (DOMINGUES, 2007; ROVIRA, 2005). Porém, os autores da dependência compreenderão esta relação com o exógeno de uma maneira bastante particular. A depen- 
dência não seria um fenômeno estritamente externo susceptível de ser eliminada com desenvolvimento econômico e com políticas independentes; a situação de dependência condicionaria as estruturas internas dos países latino-americanos. É a dependência que estabelece os limites possíveis do desenvolvimento desses países, sendo a forma específica em que se desenvolve o capitalismo na América Latina. O desenvolvimento capitalista precisaria do subdesenvolvimento de determinados países, condicionados pelo desenvolvimento e expansão das economias centrais. A dependência seria inseparável de uma divisão internacional do trabalho, em que determinados países precisam para seu desenvolvimento industrial da subordinação de outros que limitam sua economia à produção de matérias-primas e produtos agrícolas (DOS SANTOS, 1973).

Embora não seja possível falar de uma Teoria da Dependência, a elaborada por Cardoso e Faletto (2003) é considerada como a mais sólida, balanceada e completa entre elas (LARRAÍN, 1989). Refletindo o pessimismo e o ceticismo que primaram nas ciências sociais, uma vez que as virtudes que prometia o processo de substituição de importações estiveram longe de se realizar, esses autores desestimaram a ideia de subdesenvolvimento como variável explicativa. A relação entre dependência e subdesenvolvimento implicará para Cardoso e Faletto, em termos sociais, uma forma de dominação que se manifesta no modo de atuação e na orientação dos diversos grupos que participam no sistema econômico e onde as decisões que afetam a economia são tomadas em função da dinâmica e dos interesses das economias centrais.

A dependência seria o resultado da posição subalterna das economias periféricas na divisão internacional do trabalho em relação às economias centrais. A situação de dependência não seria apenas funcional à hegemonia internacional, mas também à recepção das classes dominantes locais dessa condição de subordinação. Enfatiza-se assim a natureza política dos processos de transformação econômica: o interesse está tanto nas lutas políticas entre gru- 
pos e classes como na história das estruturas econômico-políticas de dominação internas e externas.

Uma das versões mais radicais da Teoria da Dependência foi a elaborada por André Gunder Frank (1973a), um economista de origem alemã de grande influência teórica e política em finais dos anos 1960, na América Latina, e particularmente no Chile, onde desenvolveu parte importante de sua atividade acadêmica. Para esse autor, é o capitalismo mundial o que produz subdesenvolvimento, não sua ausência. Assim, o subdesenvolvimento da América Latina é o resultado de sua participação no processo de desenvolvimento capitalista mundial. As contradições capitalistas e o seu desenvolvimento histórico geram subdesenvolvimento ou lúmpen-desenvolvimento na periferia, enquanto produzem desenvolvimento nos centros metropolitanos, mediante a apropriação do excedente dos satélites. A fórmula da dependência, nesse caso, implica a ideia de que o desenvolvimento do centro é fruto do subdesenvolvimento da periferia, existindo assim uma apropriação dos excedentes de uns países sobre outros, do mesmo modo que uma determinada classe social se apropria do trabalho de outra. $\mathrm{O}$ capitalismo reproduziria a dialética interna explorador-explorado, mas desta vez entre nações.

O subdesenvolvimento não é consequência da supervivência de instituições arcaicas ou da falta de capital nas regiões que têm se mantido isoladas da torrente da história do mundo. Pelo contrário, o subdesenvolvimento tem sido e é ainda gerado pelo mesmo processo histórico que gera também o desenvolvimento econômico; o desenvolvimento do próprio capitalismo (GUNDER FRANK, 1973b, p. 26).

A polarização expropriação-apropriação na dialética metrópole-satélite ou centro-periferia penetraria o mundo subdesenvolvido criando uma estrutura interna de subdesenvolvimento. Eis a 
importância da burguesia latino-americana, a qual, para Gunder Frank (1978, p. 15), é uma lúmpen-burguesia, ou seja, na definição que ele emprega em base a uma referência a Mariano Otero:

Poderíamos qualificar de 'lúmpen-burguesia' à classe que 'não era mais que o instrumento passivo (eu diria, mais bem, ativo, A.G.F.), da indústria e do comercio estrangeiro, e seus interesses eram naturalmente os dele'. Os integrantes dessa classe 'estão profundamente interessados em nos manter no estado (ou melhor, processo [A.G.F.]) de miserável retraso do qual o comércio estrangeiro tira suas vantagens' e que poderíamos denominar 'lúmpen-desenvolvimento'.

Os dardos de Gunder Frank alvejavam as teorias do dualismo estrutural, a marginalidade e as interpretações dos Partidos Comunistas de que América Latina seria feudal e não capitalista. Não existiria um dualismo estrutural porque o subdesenvolvimento seria parte da lógica do próprio capitalismo; não existiria marginalidade, porque os assim chamados marginalizados estariam integrados sob a forma de "super exploração", pois “até os povos indígenas da América Latina, de cuja suposta economia de subsistência se diz comumente que os margina da vida nacional, se encontram totalmente integrados nessa estrutura, embora mais como vítimas super exploradas do imperialismo capitalista interno" (GUNDER FRANK, 1973b, p. 2).

Segundo o autor citado acima, as políticas reformistas de caráter nacional terminam por fortalecer os laços de dependência econômica, agravando o desenvolvimento do subdesenvolvimento, então é compreensível que conclua que a única saída para América Latina seria uma estratégia revolucionária orientada a um desenvolvimento socialista. Mas, embora reconheça o papel das forças populares na condução desse processo, na sua abordagem não existia expressamente uma atribuição específica às massas 
urbanas. Em outras palavras, se a lúmpen-burguesia é o principal artífice do lúmpen-desenvolvimento, não parece ser o lumpemproletariado o seu algoz.

Esta breve descrição de algumas das ideias básicas da dependência se justificam na medida em que os próximos dois autores a serem revisitados elaboraram suas teorias da marginalidade em diálogo com a dependência. No caso de José Nun, a dependência aparece como o pano de fundo que explica a aparição da "Massa Marginal" e, no caso de Aníbal Quijano, o "Polo Marginal” é um construto que se enquadra dentro das próprias contribuições do autor à dependência.

\section{A massa marginal: a contribuição teórica de José Nun}

O politólogo argentino José Nun (1969) desenvolverá, em um artigo intitulado "Superpoblación Relativa, ejército industrial de reserva y masa marginal", publicado na Revista Latinoamericana de Sociología, o conceito de massa marginal, mediante a discussão crítica dos conceitos marxistas de superpopulação relativa e exército industrial de reserva. Revisitando O Capital (MARX, 1946) e Grundrisse (MARX, 2011) e incorporando um conceito dinâmico de função - elementos funcionais podem virar afuncionais e até disfuncionais dependo das mudanças nas relações de produção -, o autor questionará a tendência dos estudos sobre o capitalismo, que confundem as categorias de superpopulação relativa e exército industrial de reserva, misturando os processos que produzem uma população excedente com os efeitos que ela provoca no sistema. Nun, pelo contrário, afirmará que a superpopulação relativa, ou seja, esse remanescente de população que excede as necessidades médias de exploração do capital, não constitui necessariamente um exército industrial de reserva, pois esse último conceito supõe uma relação de funcionalidade do excedente com respeito ao sistema produtivo em geral. Salientando, desta maneira, a existência de 
uma fração que permanece apenas como fator virtual em relação à organização produtiva dominante, o que sobrepassaria a lógica do exército industrial de reserva.

O exército industrial de reserva é utilizado por Marx para designar os aspectos funcionais da superpopulação relativa na fase capitalista que ele analisou. Esse exército está disponível para satisfazer a demanda por mão de obra nos momentos de expansão do sistema e, ao mesmo tempo, para evitar o aumento dos salários dos operários. A superpopulação relativa se contrai ou expande dependendo dos diversos ciclos industriais no capitalismo. $\mathrm{Na}$ fase competitiva do modo de produção capitalista, a funcionalidade da superpopulação relativa aumenta, tendo como suposto a homogeneização crescente da mão de obra para menores níveis de qualificação. Nesses momentos, corresponderia analisar a superpopulação relativa como exército industrial de reserva. Porém, Nun (1969, p. 87) observará que existe uma parte da população relativa que não produz esses efeitos funcionais. Eis a massa marginal, segundo sua definição:

Chamarei 'massa marginal' a essa parte afuncional ou disfuncional da superpopulação relativa. Portanto, este conceito - o mesmo que o de exército industrial de reserva - se situa no nível das relações que se estabelecem entre a população sobrante e o setor produtivo hegemônico. A categoria implica assim uma dupla referência ao sistema que, por um lado, gera este excedente e, por outro, não precisa dele para continuar funcionado.

Estes elementos conceituais já vinham sendo trabalhados por Nun e sua equipe (NUN et al., 1968) com anterioridade à publicação do artigo citado. Em La Marginalidad em América Latina, texto publicado em 1968 como informe de uma pesquisa patrocinada pelo Instituto Latinoamericano de Planificación (ILPES) - dependente de CEPAL - e pelo DESAL, percebe-se a insatisfação dos 
autores com as explicações dominantes em torno da marginalidade, as quais são caracterizadas como um meio termo entre a generalização empírica e a construção teórica. Como uma maneira de se distanciar destas teorias, segundo os autores, ambíguas e meramente descritivas, buscarão estabelecer as conexões entre marginalidade e relações de produção, dando especial atenção ao mercado de trabalho latino-americano. Nele seria possível detectar diferentes tipos de marginalidade, próprios do desenvolvimento capitalista tardio, dependente e combinado do subcontinente. A massa marginal é um produto do capitalismo dependente, de maneira resumida:

Um desenvolvimento capitalista desigual e dependente que combina diversos processos de acumulação no contexto de um estagnamento crônico gera uma superpopulação relativa à forma de produção hegemônica que atua, em parte, como exército industrial de reserva e, em parte, como uma massa marginal. O que é importante é que a não funcionalidade desta última está indicando um baixo grau virtual de integração do sistema, um desajuste a resolver, cuja solução organiza modos de integração social compativeis com a manutenção da matriz de relações vigentes. (NUN, 1971, p. 247).

A massa marginal aparece aqui não como uma negação do exército industrial de reserva, mas como um conjunto mais amplo que inclui no seu interior o subconjunto do exército industrial de reserva. $\mathrm{O}$ suposto implícito é que não existe apenas um tipo de marginalidade, pelo contrário, o desenvolvimento desigual, combinado e dependente, geraria diversos tipos, embora possa existir algum que resulte dominante em um determinado contexto.

A marginalidade não é simplesmente sinônimo de desocupação, pois a marginalidade se estabeleceria em relação ao setor dominante da organização produtiva que, no caso da América 
Latina, corresponde ao setor das grandes corporações monopolistas. Este contingente marginal estaria composto por: a) uma parte da mão de obra ocupada pelo capital industrial competitivo; b) boa parte dos trabalhadores refugiados nas atividades terciárias de baixa renda; c) a maior parte dos desocupados; e d) a totalidade da força de trabalho ligada ao capital comercial. Ao menos, para o autor: a), b) e c) podem seguir produzindo os efeitos diretos ou indiretos do exército industrial de reserva, porém eventualmente podem perder sua funcionalidade no sistema. A diferença entre a massa marginal e o exército industrial de reserva, segundo Nun (1969, p. 137), pode ser sintetizada da seguinte maneira:

A massa marginal - em contraste com o exército industrial de reserva clássico - indica esse baixo grau de 'integração ao sistema', devido a um desenvolvimento capitalista desigual e dependente que, ao combinar diversos processos de acumulação no contexto de um estagnamento crônico, gera uma superpopulação relativa não funcional em relação às formas produtivas hegemônicas.

A proposta conceitual desenvolvida pelo autor recebeu importantes questionamentos. A polêmica mais célebre foi a que o argentino teve com o sociólogo brasileiro Fernando Henrique Cardoso (1970), que acusará Nun, entre outras coisas, de ler equivocadamente os textos de Marx, de outorgar uma importância excessiva ao Grundrisse em relação a $O$ Capital e de incorporar uma definição de funcionalidade alheia ao próprio marxismo. E, embora Cardoso reconheça o problema da marginalidade como um fenômeno real e visível na superfície da vida social, criticará Nun por reproduzir uma sociologia do "escândalo de uma situação social" já super-representada nas agências internacionais e nos governos latino-americanos. Não é do interesse deste texto aprofundar tal polêmica, pois, para o desenvolvimento do argumento, o grau de literalidade com que Nun trabalha suas referências a Marx são 
irrelevantes. Precisamente sua importância para esta reflexão é o caráter heterodoxo de suas leituras, que derivaram no seu conceito de massa marginal.

Neste sentido, mais significativo para este debate é a Critica à razão dual de Francisco de Oliveira (1972), quem questionará a oposição de um setor "atrasado" versus um setor "moderno" na economia como um atributo apenas do desenvolvimento latino-americano. Para Oliveira, existiria uma simbiose e organicidade entre o moderno que cresce e se alimenta da existência do "atrasado". Sob a mesma lógica, o crescimento do mercado de trabalho informal estaria estreitamente ligado à acumulação urbano-industrial. Os diferentes serviços providos pelo setor informal não são "excrescências" do exército industrial de reserva, mas formas de adequação ao processo de acumulação global e à expansão capitalista. Assim, embora a crítica esteja mais orientada às diversas variações da teoria cepalina, alcança também as formulações sobre marginalidade, incluindo certamente o próprio Nun. A massa marginal seria, para Oliveira, funcional - no caso do seu estudo - à acumulação capitalista primitiva da economia brasileira.

Porém, o viés funcionalista da crítica de Oliveira é precisamente uma das vertentes características das ciências sociais da época, da qual Nun explicitamente pretende se distanciar. Daí sua opção por uma definição dinâmica de função, que pode derivar em afuncionalidade ou disfuncionalidade dependendo do contexto. Ironicamente Nun afirmará que, para o funcionalismo marxista da academia, até o pescador no interior da Amazônia é, em último termo, funcional à acumulação capitalista e vítima de sua exploração. Contudo, a perspectiva de Oliveira oferece um arcabouço analítico bastante interessante para compreender o fenômeno urbano na América Latina, reflexões que terão impacto mais adiante na literatura urbana paulista, que anos mais tarde vai propor um reordenamento do debate (ver capítulo 4). Para Oliveira (1972, p. 31), "o processo de crescimento das cidades brasileiras não pode ser 
entendido senão dentro de um marco teórico onde as necessidades da acumulação impõem um crescimento dos serviços horizontalizado, cuja forma aparente é o caos das cidades".

Agora, qual é o papel da questão urbana na Teoria da Marginalidade de José Nun? Considerando a crítica do autor argentino às teorias da marginalidade que atribuíam determinadas características sociais aos grupos sociais que habitavam as diferentes formas de habitação precária simplesmente por compartilharem uma realidade ecológica, não surpreende o negligente tratamento da questão urbana na sua produção, a qual praticamente desaparece de sua análise em favor do estudo do mercado do trabalho. Para Nun e sua equipe (1968), o slum aparece como uma característica inevitável da industrialização e do desenvolvimento urbano. Não é, portanto, uma forma urbana exclusiva da América Latina, pois na industrialização europeia também esteve presente. O slum se encontra tanto em mercados autônomos como dependentes. Logo, o diferencial não é o slum em si próprio, mas sim as perspectivas reais de mobilidade de quem os habita, as quais estão extremamente limitadas, por razões estruturais, nos mercados dependentes.

O descuido da questão urbana nos textos de Nun não impedirá que o autor argentino desenvolva algumas reflexões em torno do papel político das massas marginais, porém estas cogitações terão um papel notadamente secundário no seu argumento. Não obstante, sua elaboração teórica começa como um esforço reflexivo dedicado à revisão de três tradições clássicas na literatura das ciências sociais: a de exército de reserva, a de pobreza e a das classes sociais (NUN et al., 1968). Nessa análise, orientada a delimitar conceitualmente a noção de marginalidade, o diálogo com a teoria das classes sociais na sua dimensão política será extremamente limitado.

$\mathrm{Na}$ contrarréplica de Nun (1971) aos questionamentos realizados por Fernando Henrique Cardoso (1970), o argentino 
esclarecerá que o propósito de suas explorações conceituais não é meramente exegético, mas sim prático: distinguir formas em aparência distorcidas de integração do sistema social e, ao mesmo tempo, contribuir ao desenvolvimento de estratégias revolucionárias que tomem em consideração a complexa fragmentação das classes subalternas latino-americanas. Declaração de boas intenções ou não, Nun (1971, p. 247) parece convencido da importância da teoria social para a definição de estratégias políticas: "Esta urgente tarefa de unificação reclama elaborações teóricas, ferramentas conceituais e estudos empíricos que fossem para além dos discursos de moda sobre o atraso e sobre a dependência”.

A massa marginal é para o autor, ao mesmo tempo, uma esperança e um risco. É uma esperança pela natureza das contradições potenciais que a constituem e pelos desdobramentos que essas contradições podem ter para a luta de classes. Mas é também um risco, pois na ideia de massa marginal está implícita a permanente desagregação da estrutura social. A inclinação particularista, localista e até corporativista da massa marginal, pela natureza diversa das causas e motivos de eventuais mobilizações, a poderiam levar a formas de luta, segundo o argentino, desviadas, desesperadas, populistas e manipuladas. A massa marginal, nesse ponto, não é diferente da massa de manobra das teorias dualistas da marginalidade. E, embora Nun reconheça que o fenômeno da marginalidade se poderia traduzir em formas originais de luta de classes, na prática, o que primaria seria a incapacidade da massa marginal para transcender objetivos estritamente imediatos, formas de organização instrumentais e lógicas de participação subordinadas (NUN et al., 1968).

\section{Polo marginal e marginalização em Anibal Quijano}

Aníbal Quijano se instalará no Chile entre 1966-71 como pesquisador principal do Programa de Investigaciones sobre Ur- 
banización y Marginalidad, na divisão de Assuntos Sociais da CEPAL, mas construirá uma agenda de pesquisa bastante independente em relação ao organismo internacional. Uma de suas primeiras tarefas intelectuais será a crítica das tendências dualistas de explicação da marginalidade. Essas perspectivas não estabeleceriam uma relação significativa entre a situação social dos indivíduos, chamados "marginais", e as tendências estruturais da sociedade, pelo qual a "marginalidade" apareceria como um atributo dos próprios indivíduos, assumindo, de maneira implícita, que não era necessário problematizar a própria sociedade como tal. Ficaria em evidência com isso, para Quijano (1970), a carga ideológica dessa linha de pesquisa, pois o apelo à "integração dos marginais à sociedade" pressupõe que a marginalidade não é um problema da estrutura da sociedade. Este enfoque empirista e meramente descritivo, segundo o sociólogo peruano, se limitaria à constatação da existência de determinados segmentos da população com determinadas carências e suas pretensões explicativas se esgotariam na descrição das características dessas populações.

No enfoque de Quijano, a "marginalidade" é um conceito que dá conta da inserção indireta, fragmentária e instável de crescentes segmentos da população no modo de produção capitalista dependente. Esses segmentos ocupam o nível mais dominado da ordem social. Logo, a situação de marginalidade é analiticamente independente dos indivíduos que a experimentam, pois é resultado das tendências próprias das relações de produção da periferia dependente. O objetivo de Quijano será, portanto, estabelecer as relações específicas entre o fenômeno da "marginalidade" na América Latina e o caráter dependente, desigual e combinado das formações histórico-sociais próprias do subdesenvolvimento capitalista.

A urbanização na América Latina é um processo dependente, ou seja, suas tendências e características mais destacadas estão marcadas pelas relações de dependência de nossas sociedades. Isto 
se mostraria de duas maneiras: 1) nas mudanças no perfil da rede urbana em cada um dos períodos destacados de modificação do sistema de dependência; e 2) nos câmbios no conteúdo da sociedade urbana que habita essa rede ecológico-demográfica nos mesmos períodos.

Este sistema de relações de dependência, em interação com as singularidades da matriz histórico-social de cada uma de nossas sociedades nacionais, constitui um dos seus núcleos de fatores determinantes das tendências básicas de existência e de mudança. Não é possível, em consequência, explicar adequadamente o processo conjunto de mudança na América Latina, nem nenhuma das suas dimensões significativas, à margem desta situação histórica. O processo de urbanização em particular, não pode ser explicado, validamente, senão como parte da mais ampla problemática da sociologia da dependência latino-americana. (QUIJANO, 1967, pp. 2-3).

A história do fenômeno urbano na América Latina não poderia ser separada do fenômeno da dependência (QUIJANO, 1966). Nessa perspectiva, a história da América Latina é a história de sucessivas dependências, e cada uma delas deixou sua marca no desenvolvimento urbano. $\mathrm{Na}$ fase de capitalismo dependente da primeira metade do século XX, se experimentará um crescimento urbano dado pelo incremento da população nas cidades e pelo aumento do número de cidades. $\mathrm{O}$ processo de modernização, em geral, implicará uma modernização urbana que repercutirá na sociedade e na cultura urbana e tradicional. $\mathrm{O}$ limitado processo de industrialização estimulou não apenas o crescimento urbano, mas também a mudança de motivações e aspirações da população. Essas transformações foram superiores à capacidade da industrialização para satisfazer às aspirações e motivações desencadeadas. 
O que caracteriza todas estas áreas que hoje concentram o processo de urbanização, seja em termos de cidade ou em termos de uma região inteira dentro de um país, é o fato de que todos os casos funcionam como auténticas cabeças de ponte das relações de dependência de seu país com as metrópoles externas, e como focos de concentração dessa relação e de seus grupos de poder correspondentes, em todas as ordens. (QUIJANO, 1967, p. 28).

Esta tendência em concentrar o desenvolvimento urbano nas zonas diretamente articuladas ao sistema de dependência, ou seja, onde se produz a expansão e câmbio da economia urbana, estimula a atração para estas áreas de população de outras cidades e localidades de maior subdesenvolvimento. Produz-se assim um desnível no interior das sociedades em termos de desenvolvimento e modernidade. Com isto, se consolida uma dupla dependência, pois o campo passa a ser dependente da cidade, amplificando e aprofundado o "colonialismo interno".

Nessas condições, grande parte da população das zonas rurais e das próprias localidades semi-urbanas enclavadas nas áreas rurais, é lançada fora das estruturas ocupacionais e de relações econômicas, que tendem a se deteriorar mais rapidamente e a acentuar sua situação de crise já bastante extendida no tempo. Isto acontece precisamente no mesmo momento em que as taxas de crescimento da população dessas zonas tendem a alcançar índices muito elevados. Desse modo, a marginalização da população rural encontra uma saída na migração para as cidades e as áreas onde a economia urbana está em expansão, e nessas áreas só pode achar as condições restritivas do mercado de trabalho e do mercado em geral e é, de novo, marginalizada e, desta vez, definitivamente. (QUIJANO, 1967, p. 40) 
O deslocamento da base agrário-extrativa da estrutura tradicional de produção para uma nova base industrial, com suas consequências no câmbio ecológico, nas relações demográficas entre o urbano e o rural, será entendido por Quijano (1968) como um processo de "urbanização da economia". Esta dependência do urbano sobre o rural terá implicaçôes culturais, já que estará acompanhada de um processo de "urbanização" do campo, entendida como a difusão de elementos culturais urbanos sobre o mundo rural. Essa visão contrasta radicalmente com a defendida pelos estudos associados ao "dualismo estrutural", os quais enfatizavam a influência cultural rural sobre a formação das novas sociedades urbanas como consequências da migração. Confundia-se migração populacional com migração cultural, e salientava-se a "ruralização" de muitos aspectos da vida urbana.

Contudo, Quijano (1968, p. 7) não negará a influência recíproca entre cultura urbana e cultura rural, aliás, conceberá a cultura rural nas cidades como uma alternativa cultural, especialmente quando esta se expressa como afirmação da cultura indígena de certos países. Essa cultura rural permeará preferencialmente os setores populares. Assim, na cidade será possível encontrar:

Uma 'cultura urbana dependente' formada com modelos e elementos procedentes das metrópoles externas dominantes, [a qual] compete com uma 'cultura urbana popular' formada em grande parte com modelos e elementos chegados com a migração rural ou urbana tradicional, menos estruturada e menos influente na sociedade, e que forma a subcultura urbana dominada.

Os marginalizados do campo, ao chegarem à cidade, se encontram com o caráter restritivo do mercado urbano de trabalho dominante, o qual não dá conta das crescentes ondas migratórias nem das novas gerações de populares nascidos nas mesmas cidades. A industrialização dependente é excludente e sua lógica contém a 
inevitabilidade da "marginalização" de amplos setores da população urbana, seja porque os deslocados não encontram um papel no novo sistema industrial, seja pela progressiva declinação de alguns ramos da atividade produtiva frente a outras de maior tecnologia e aos monopólios estrangeiros.

O processo de "revolução tecnológica", operado no desenvolvimento capitalista do século XX, introduz um novo desequilíbrio entre os diversos ramos da produção, acentuando a desigualdade do desenvolvimento de vários setores da estrutura econômica. Essa revolução implicará também uma redução da mão de obra, que na América Latina se expressará especificamente pela existência de uma população excedente que não tem nenhuma possibilidade de ser incorporada ao setor mais moderno da economia ou "polo hegemônico". É uma população que não tem nem a função de reserva, simplesmente sobra, tendo como única saída o refúgio nas áreas de menor produtividade e nas empresas de menor capacidade tecnológica e financeira. Existe um processo de marginalização de um conjunto de papeis e relações econômicas frente aos níveis predominantes de produtividade do sistema paralelo ao processo de marginalização da mão de obra.

Surge assim o "polo marginal" da estrutura econômica, configurado pelas ocupações de mínima produtividade e de baixa qualificação. Em outras palavras, as ocupações marginais cujo mercado é reduzido e instável e seus salários baixos ou limitados (sem prestações sociais).

O conceito de 'polo marginal' da economia permite mostrar que a mão de obra 'marginalizada' não é expulsa do sistema, nem se produz o que alguns economistas, dentro e fora da América Latina, concebem como um novo 'dualismo estrutural': a oposição entre um 'setor integrado' e um 'setor marginal'. Pelo contrário, do que se trata é da acentuação dos desequilíbrios entre os vários níveis do sistema, pelo desenvolvimento ou, melhor, crescimen- 
to de um nível cuja significação para as necessidades de produtividade dos setores nucleares do sistema é quase insignificante e que é, neste preciso sentido, 'marginal', e apesar do qual faz parte integrante do sistema considerado no seu conjunto e obedece à sua lógica histórica de desenvolvimento. (QUIJANO, 1970, p. 20-1).

O processo de "marginalização social" é produto de um conjunto de condições históricas dadas pela implementação de uma industrialização dependente e organizada de forma monopólica dentro de uma estrutura socioeconômica que combina desiguais níveis e relações de produção. A marginalização consiste na diferenciação crescente de segmentos da classe operária que ocupam posições precárias e instáveis no mercado de trabalho, as quais não têm significação para a acumulação capitalista. Quem sofre a marginalização teria uma existência marcada pela pauperização social, econômica e cultural e suas ocupações seriam apenas refúgios destinados à sobrevivência.

A situação de pauperização, como já dito, não é um atributo pessoal ou coletivo. É, sobretudo, uma cristalização da relação básica de dominação-marginalização, imposta na América Latina como condição mesma da existência e desenvolvimento do capitalismo na periferia dependente. Por isso, Quijano (1972b, p. 12), em contraste com a linguagem dualista da marginalidade, preferirá falar de marginalizados e não de marginais. Não se pode culpar aos marginalizados de sua própria condição de marginalidade. Não se pode, por um lado, segregá-los dos bens da cultura hegemônica e, por outro, culpá-los pela ausência de hábitos e disposições para o trabalho organizado, ou para as normas sociais modeladas de acordo com os gostos dos setores médios e burgueses.

Este sistema de instabilidade ocupacional e de refúgio em ocupações marginais constitui não uma condição ou uma característica 
dos próprios indivíduos marginalizados, mas sim uma relação entre estes e a burguesia dominadora da sociedade. Esta relação, por sua vez, é diferente da qual se estabelece entre essa mesma burguesia e os trabalhadores ativos. No primeiro caso se trata de um sistema de exploração indireta, via exclusão dos ingressos e dos bens e serviços e de uma relação que implica a completa subordinação ao poder burguês; no segundo, de uma exploração direta, via extração de mais-valia.

Essa interpretação será chave na conformação do debate que se desenvolverá no Chile com Castells e parte da equipe do Centro Interdisciplinário de Desenvolvimento Urbano (CIDU). A leitura econômica da marginalidade será fonte e, até certo ponto, parte integrante da literatura sobre Movimentos Sociais Urbanos (MSU). Ao mesmo tempo, Quijano incorporará, na sua concepção do processo de marginalização, a experiência do Movimento de Pobladores, estudado pelo CIDU, abrindo espaço na sua interpretação estruturalista para as potencialidades da ação transformadora desse movimento social.

Segundo Quijano, a relação entre o Estado e os marginalizados flutua entre o assistencialismo paternalista (Promoção Popular), para amortecer os conflitos, e a repressão violenta, para submeter os descontentes, reduzindo a participação política dos marginalizados a uma posição subordinada que reforça a situação de marginalidade social. Porém, esta relação não supõe apenas dominação, mas também conflito, o que cresce na mesma medida em que a dominação se acentua. Além do mais, tanto a repressão quanto o assistencialismo implicam uma relação direta com Estado, que politiza automaticamente qualquer tipo de conflito desatado pelos marginalizados. Se os proletários lutam desde o interior mesmo da estrutura produtiva, os marginalizados o fazem desde a demanda de satisfação das necessidades básicas: habitação, alimen- 
tação, serviços urbanos etc. Contudo, segundo o autor peruano (1972a, p. 22),

Esta peculiar situação dificulta o trânsito da consciência social, desde estes interesses de sobrevivência física, ao problema mesmo da dominação. Paradoxalmente, porém, as lutas dos marginalizados pela obtenção dos mínimos recursos indispensáveis, atingem imediata e diretamente certos aspectos importantes do regime de propriedade privada ao se apropriarem de terras urbanas para habitar. Sem afetar, necessariamente, os elementos centrais do sistema imperante de dominação dos recursos de produção, os marginalizados chegam, assim, a questionar, de modo empírico, o regime legal de propriedade em geral.

Ao mesmo tempo, os marginalizados introduzem no cenário das lutas político-sociais o elemento da violência, pelas próprias tomadas de terrenos ou pela constituição embrionária de milícias populares, no caso do Chile. Para Quijano, o movimento de pobladores chileno representa o caso onde o desenvolvimento das lutas dos marginalizados por habitação e serviços urbanos alcançou um nível mais alto de violência e organização, influindo inclusive no restante dos trabalhadores. A constituição destes núcleos de poder relativamente autônomo dos marginalizados evidenciou o papel deste sujeito nas mudanças revolucionárias que prometia o governo da UP de Salvador Allende ou mesmo na defesa armada, junto ao resto dos trabalhadores, do Governo Popular:

$\mathrm{Na}$ hora da revolução chilena, assediada ainda por todos os perigos, desde a capacidade de revanche contrarrevolucionária da burguesia, até os riscos de imposição de um poder burocrático sobre a sociedade revolucionária, o desenvolvimento de tendências de construção de núcleos e de mecanismos de poder popular em alguns dos acampamentos revolucionários dos trabalhadores 
marginalizados, não é de nenhuma maneira um elemento que se deva subestimar. Pela primeira vez neste país, aparecem embriões de poder popular-local, onde os pobladores e trabalhadores marginalizados podem participar efetivamente na decisão de seus problemas e de sua vida cotidiana, e não meramente existir como fator de apoio desde fora dos centros reais de poder político. Ali, estas tendências podem ainda servir como marcos e ponto de apoio para a luta dos dominados por controlar, em todos os níveis e de modo efetivo e não por mediação burocrática, os centros de decisão de seu destino. (QUIJANO, 1972a, p. 26).

\section{Contribuições e limites da marginalidade em sua versão marxista}

Apesar de José Nun e Aníbal Quijano terem percorrido caminhos paralelos de reflexão, no momento de decantar conceitualmente suas propostas analíticas, conseguiram se encontrar nas categorias de massa marginal e polo marginal. Estranha que essa proximidade nas suas categorias centrais não tenha se traduzido em colaboração teórica ao longo de seus trabalhos. Se Quijano vai reconhecer essa cercania conceitual, Nun (1999), em contraste, o fará parcialmente, classificando o conceito do peruano como mais descritivo. Qual conceito é tributário do outro? Em verdade, a resposta pouco importa; para os fins desta reflexão, é apenas relevante o parentesco entre as duas categorias e seu papel na compreensão dos movimentos de pobres urbanos na América Latina, particularmente no Rio de Janeiro e em Santiago do Chile.

A adjacência conceitual entre polo e massa marginal implicará que seus autores compartilhem méritos e limitações na sua abordagem da questão social urbana. Segundo Machado e Ziccardi (1983), a contribuição de Nun e Quijano foi a superação do tratamento a-histórico e estático da questão da marginalidade, introduzindo a ideia de que a própria dinâmica do sistema cria os grupos 
marginais. Estes não seriam, portanto, estritamente "marginais", senão mais propriamente "marginalizados" pelo sistema. Neste ponto, Nun e Quijano abriram caminho para a superação da questão da integração dos grupos marginais, estabelecendo as condições teóricas para dar um passo rumo à transformação da questão da marginalidade em uma problemática dos graus e formas de exploração da força de trabalho, através da introdução da discussão dos processos sociais que geram a "situação marginal".

Apesar do viés econômico de Nun e Quijano na compreensão da problemática da marginalidade, segundo os já citados Machado e Ziccardi, nesta vertente da marginalidade se observa um processo de politização da problemática urbana. Assim, ambos autores podem ser considerados antecedentes da discussão que vai ser inaugurada com a escola dos Movimentos Sociais Urbanos (MSU). Com Nun e Quijano, a marginalidade deixa de ser uma questão transitória suscetível de ser mudada com reformas sociais. Pelo contrário, a marginalidade se explica pela dinâmica própria do capitalismo dependente. Logo, a superação da marginalidade só é possível com a transformação do modo de produção.

Porém, como já dito, o tratamento da questão política da massa marginal é extremamente limitada no caso de Nun. Se, com seu conceito de massa marginal, rompe radicalmente com a explicação dualista da marginalidade, do ponto de vista político, o argentino termina por reproduzir as noções políticas das teorias que ele critica a respeito dos marginalizados, e a massa marginal, nesta dimensão, fica subsumida na ideia de massa de manobra. Em contraste, Aníbal Quijano incorporará à sua explicação do polo marginal a concepção de marginalizados radicais própria dos MSU. Contudo, estes desdobramentos políticos não se depreendem diretamente do corpus teórico central do autor. Aliás, o potencial disruptivo dos marginalizados é discutido por Quijano em um texto secundário como prólogo de um livro pouco conhecido: Vidas Marginales, de Carmen Pimentel (1972). É provável que 
esta integração temática tenha sido possível pela proximidade do autor, por causa de sua residência em Santiago, com a experiência do Movimento de Pobladores chileno durante o governo Allende e com os autores dos MSU, que nesse mesmo período estudavam a ação dos pobladores, tendo como marco teórico, entre outros autores, os aportes do próprio Quijano.

Embora a ênfase de Nun e Quijano esteja mais na estrutura que na agência, para colocar em termos clássicos, as contribuições conceituais destes autores serão fundamentais para as análises que situarão os pobladores e favelados no centro de suas elaborações sociopolíticas e os considerarão atores determinantes para as transformações sociais no continente. 


\section{Capítulo 3}

\section{O MOVIMENTO DE POBLADORES COMO MOVIMENTO SOCIAL URBANO (1970-73)}

O Chile de finais dos anos 1960 e começo dos anos 1970 era o epicentro de múltiplos processos. Se por um lado, a instalação, há quase duas décadas no país, de duas das mais importantes instituições de pesquisa latino-americana, FLACSO e CEPAL, já tinha atraído uma massa intelectual crítica excepcional, por outro, a intensa e acelerada aplicação de reformas sociais, iniciada primeiro com a Revolução em Liberdade do social-cristão Eduardo Frei Montalva (eleito em 1964) e aprofundada mais tarde com a eleição do socialista Salvador Allende (eleito em 1970), com sua "via chilena ao socialismo", tinha convertido o país num foco extremamente atraente para os pesquisadores que queriam compreender as mudanças que experimentava (BEIGEL, 2013; DEVÉS VALDÉS, 2004a).

O Chile, entre 1970 e 1973, experimentou um processo de "hiper-mobilização" da sua sociedade (LANDSBERGER e MCDANIEL, 1976), notadamente das suas classes subalternas: a classe operária, os camponeses e os pobladores. As cidades chilenas foram um verdadeiro laboratório da mudança social, sendo a maior novidade a consolidação do movimento de pobladores.

Dessa maneira, em Santiago do Chile, contagiado pelo clima de efervescência social e política reinante neste país, no começo dos anos 1970, um grupo de pesquisadores se dedicará ao estudo do que parecia ser um novo ator social potencialmente decisivo 
na polarização chilena da época: os pobladores. Estes intelectuais identificaram nos marginados (ou no lumpemproletariado) "uma ponta de lança urbana”, segundo a expressão de Fanon (2007), dos processos de transformação social que experimentava o continente.

Este capítulo visará precisamente mostrar quais foram as principais ideias e contribuições realizadas por este grupo de pesquisadores. Para tanto, mostrarei como um antecedente intelectual indireto a compreensão que Frantz Fanon fez do papel político do lumpemproletariado. Embora a tendência consolidada nas ciências sociais seja considerar o autor martinicano como um teórico da marginalidade radical, neste capítulo apresentarei argumentos que contradizem tal definição. Em contraste, o mostrarei não como um teórico da questão urbana, mas sim como o intelectual anticolonialista que influenciou profundamente uma série de cientistas sociais identificados com a esquerda radical, destacando como sua perspectiva política permite compreender alguns dos principais posicionamentos do grupo que nesse período fez do movimento de pobladores seu principal objeto de pesquisa.

Finalmente, me deterei na trajetória teórica do autor mais destacado deste grupo de pesquisadores, Manuel Castells, tentando mapear as principais transformações que experimentou seu pensamento urbano, com especial atenção no conceito que é mais caro a esta pesquisa: o de movimentos sociais urbanos.

\section{Os marginalizados como ponta de lança da transformação social: Frantz Fanon e a marginalidade}

Sem dúvida, entre os autores da teoria da marginalidade, existia uma tendência a associar o processo de urbanização nos países subdesenvolvidos com a radicalização e a violência política das camadas populares que, ao migrarem à cidade, não tinham satisfeitas as expectativas que a própria economia urbana gerava. Isto levará diferentes autores (SILVA e ZICCARDI, 1983; OLIVEN, 
1980) a considerarem a figura de Frantz Fanon como um dos mais lúcidos expoentes da visão de esquerda dessa teoria. Afirmação que se sustentava com a citação de uma passagem da famosa obra do autor martinicano, Os Condenados da Terra:

É nessa massa, nesse povo dos cordões de miséria, das casas 'de latão', no seio do lumpemproletariado onde a insurreição encontrará sua ponta de lança urbana. O lumpemproletariado, coorte de famintos destribalizados, desclanizados e radicalmente revolucionários de um povo colonizado. (FANON, 2007, p. 119).

Não obstante a frase citada sintetize magistralmente uma concepção do lumpemproletariado que chegará a ser hegemônica entre os intelectuais de esquerda que estudaram o fenômeno urbano durante o começo dos anos 1970, particularmente no Chile, resulta equívoco entender a produção de Fanon como a de um teórico da marginalidade. A preocupação do autor será o processo de descolonização do terceiro mundo, que estava em curso quando publicou Os Condenados da Terra, em 1961, e que transformou sua obra, segundo René Ménil, no "novo evangelho da libertação dos povos" (apud PIERRE-CHARLES, 2011, p. 51). Aliás, será o próprio processo de luta anticolonial que levará Fanon a refletir sobre o papel das diferentes camadas dos indígenas colonizados. Nesta análise, estará incluído o lumpemproletariado, mas não será ele o foco de seu raciocínio, e sim os camponeses.

Para Fanon, a chave da revolução anticolonial está nos camponeses, pois, na sua visão, a dicotomia urbano/rural parece reproduzir a diferenciação colonial/anticolonial. Tal como explica no texto, da perspectiva do mundo rural:

Os habitantes da cidade são 'traidores, vendidos', que parecem se levar bem com o ocupante e tratam de triunfar dentro do marco do sistema colonial... Estamos frente à clássica oposição entre o 
campo e a cidade. É a oposição entre o colonizado, excluído das vantagens do colonialismo e o que consegue tirar benefício da exploração colonial (FANON, 2007, p. 103).

Os camponeses são as principais vítimas do processo de colonização, já que o mundo rural não observa nenhum benefício da situação de colonização, pelo contrário, se vê constantemente ameaçado pela inserção de novas formas de vida que rivalizam com as tradições e os valores locais. Neste cenário, os operários aparecem como a fração do povo melhor acomodada e mais favorecida pelo regime colonial, já que o colonizador estaria ciente do papel estratégico do operariado para a continuidade do regime. Logo, não demoraria em "seduzir" esta camada popular, deixando-a numa situação de relativo privilégio. Os operários, porém, teriam algo a perder numa revolução anticolonial, por isso Fanon (2007, p. 100) chamará a atenção para o fato de que:

O grande erro, o vício congênito da maioria dos partidos políticos nas regiões subdesenvolvidas tem sido se dirigir, segundo o esquema clássico, principalmente às elites mais conscientes: o proletariado das cidades, os artesãos e os funcionários, ou seja, uma ínfima parte da população que não representa muito mais que um por cento.

Esta dessacralização do papel do proletariado na revolução anticolonial implicará uma valorização política de outras camadas populares, destacando os camponeses. Nesse contexto, o lumpemproletariado, esse setor que vive amontoado nos bairros miseráveis da periferia da cidade, será concebido como um grupo constituído principalmente por "camponeses sem terra" que tiveram que abandonar o campo pela sua condição de "bocas excedentes". Boa parte da revalorização política que Fanon faz do lumpemproletariado depreende-se da importância que outorga ao campesinato na luta 
contra a colônia. Essa ideia fica mais clara se citamos novamente a passagem completa do parágrafo referido no começo desta seção.

A insurreição, surgida do campo, penetrará nas cidades pela fração do campesinato bloqueada na periferia urbana, a qual não tem podido encontrar ainda um osso que roer no sistema colonial. Os homens obrigados pela crescente população do campo e a expropriação colonial a abandonar a terra familiar, perambulam incansavelmente pelas diferentes cidades, esperando que um dia ou outro se lhes permita entrar. É nessa massa, nesse povo dos cordões de miséria, das casas 'de latão', no seio do lumpemproletariado onde a insurreição encontrará sua ponta de lança urbana. $\mathrm{O}$ lumpemproletariado, coorte de famintos destribalizados, desclanizados e radicalmente revolucionários de um povo colonizado (FANON, 2007, pp. 118-9).

Esta concepção do lumpemproletariado como uma extensão urbana do campesinato presente em Fanon é próxima da visão da Teoria da Marginalidade, a qual pensava as formas de habitação marginais (favelas, callampas, tugúrios etc.) como um quisto rural na cidade. Mas, apesar desta relação ser um traço fundamental da Teoria da Marginalidade, esta convergência não é suficiente para considerar o autor como um expoente de esquerda da Marginalidade. São outros os debates, outras as bibliografias e outros os protagonistas na sua literatura.

Todavia, resulta interessante destacar que a valorização política do lumpemproletariado sobre a do papel de um proletariado em situação de privilégio, será recebida com particular sensibilidade por setores da esquerda radicalizada latino-americana (no final dos anos 1960), a qual incorporará essa ideia em sua práxis política como uma arma de disputa do mundo popular frente aos partidos de esquerda tradicionais (principalmente os Partidos Comunistas), extremamente influentes no proletariado urbano. 
Sem dúvida, a valoração política do lumpemproletariado realizada por Fanon é meritória, sobretudo se se considera a desconfiança que a esquerda tradicionalmente mostrou frente a esse setor. Porém, esse receio está presente, embora matizado, no próprio Fanon (2007, p. 125):

O colonialismo encontrará igualmente no lumpemproletariado uma massa considerável propícia para a manobra. Todo movimento de libertação nacional deve prestar o máximo de atenção, pois, a esse lumpemproletariado. Este responde sempre à chamada à insurreição, mas se a insurreição acredita que pode se desenvolver o ingnorando, o lumpemproletariado, essa massa de famintos e marginalizados, se lançará à luta armada, participará no conflito, mas do lado do opressor.

O perigo de que o lumpemproletariado vire reserva humana mercenária disponível para lutar do lado das tropas coloniais é o que leva Fanon a ser tão enfático quanto à necessidade de fazer um trabalho político conscientizador, por parte dos partidos nacionalistas, entre os membros desta camada. Aliás, o autor reconhece no lumpemproletariado um ator político que pode ser desequilibrante na luta de libertação nacional. Assim, um setor popular marginalizado, mesmo pela esquerda, cobra centralidade política na sua obra. Esta será só uma das ideias do autor que terão eco na intelectualidade da época.

Antes de ser uma obra sobre a marginalidade, Os Condenados da Terra é um manifesto anticolonial. E a contribuição desta obra para a Sociologia dos Pobres Urbanos parece ser mais um reflexo do clima intelectual da época de sua publicação (processo de descolonização, Revolução Cubana etc.) e, consequentemente, da influência que teve no campo intelectual de esquerda que, posteriormente, iniciou os debates sobre camadas populares urbanas. Já assinalou Karl Mannheim (1963) que a história do pensa- 
mento não é apenas uma história das ideias, mas também deve ser compreendida e analisada segundo os diferentes "estilos de pensamentos" desenvolvidos pelos diversos grupos sociais. Portanto, o desenvolvimento e exercício reflexivo dos intelectuais não pode ser separado do ambiente social e histórico no qual nascem, se desenvolvem, se fundem e desaparecem suas ideias. Frantz Fanon, para seguir utilizando uma metáfora mannheimniana, forma parte da constelação intelectual que deu origem ao pensamento que se desenvolveu no Chile no âmbito popular urbano.

Nesse sentido, a influência de Fanon sobre os intelectuais de esquerda (radical) foi gravitante nos projetos políticos que buscaram dar uma consistência orgânica à potencialidade dos marginais da cidade. Esta marca não estará dada apenas pelo papel do lumpemproletariado, mas também pela importância outorgada à violência no processo de unificação das lutas nacionais e populares: "Apenas a violência exercida pelo povo, violência organizada e aclarada pela direção, permite às massas decifrar a realidade social, lhe dá a chave dela" (FANON, 2007, p. 135). No caso do Chile, isto se apreciará no Movimento de Esquerda Revolucionária (MIR em espanhol), cuja práxis no mundo urbano popular atraiu parte importante da intelectualidade que elaborou a ideia de Movimentos Sociais Urbanos.

\section{Os Pesquisadores do CIDU}

O Centro Interdisciplinario de Desarrollo Urbano (CIDU), nascido como consequência da Reforma Universitária que experimentou a Pontifícia Universidade Católica do Chile em 1968, foi o principal grupo de pesquisa que articulou a produção dos autores que buscaram compreender o papel desempenhado pelos pobladores no processo de mudança social experimentado pelo país. Ante seus olhos se apresentava um movimento com características inéditas por sua massividade, combatividade e politização 
(PASTRANA e THRELFALL, 1974). Mais especificamente, este centro tentou compreender a novidade político-social que representava o movimento organizado a partir do estabelecimento de inúmeros campamentos ${ }^{1}$, originados por tomadas de terrenos dirigidas por militantes dos principais partidos políticos do país desde o centro até a esquerda (Partido Democrata Cristão, Comunista, Socialista e Movimento de Esquerda Revolucionária).

A primeira tarefa que esses pesquisadores tiveram foi demonstrar a falsidade das teses da teoria da marginalidade desaliana. Questionando a ideia de concentração de lúmpen associada às habitações marginais, os diversos estudos empíricos realizados por esses autores demonstraram a "heterogeneidade popular" do universo poblacional, na qual assume um lugar destacado, uma fração específica da classe operária ("operariado em crise"). Isto permitiu, ao mesmo tempo, problematizar a ideia de subcultura marginal (ou "cultura da pobreza", segundo o já mencionado Oscar Lewis) e afirmar a existência de uma cultura nos bairros populares, mas que vive ao ritmo ideológico e político dos processos gerais da luta de classes na sociedade. Nas palavras do mais destacado desses autores:

As poblaciones não são o refúgio da desintegração social nem apresentam uma concentração de lúmpen, senão são a única forma possível de residência para uma fração da classe operária (aquela dos setores 'tradicionais') à qual se agregam uma boa parte do proletariado da grande indústria, e até empregados e pe-

1 Para Santa María (1973), o “campamento” é uma organização social e territorial e uma forma de crescimento não planejado do solo urbano que, nos anos 1970, representava a operação urbana de maior importância na cidade de Santiago, seja na forma de assentamento espontâneo ou na forma de tomada organizada.

2 Castells (1972) distingue entre a "aristocracia operária”, que age de maneira economicista no âmbito poblacional e que é conduzida pelo PC, e o "proletariado em crise", politicamente radicalizado a partir da reivindicação urbana e conduzido pela esquerda revolucionária. 
quenos burgueses, embora os grupos operários sejam claramente hegemônicos. (CASTELLS, 1972, pp. 14-6).

Ao mesmo tempo, Castells criticará a lógica de intervenção da teoria da marginalidade elaborada pelo DESAL, enquanto doutrina orientada a fundamentar a práxis política do Partido Democrata Cristão (DC). A marginalidade se apresenta como uma tentativa de ocultar a relação de exploração, que seria o produto do tipo de integração de um regime capitalista, logo, as causas da marginalidade, que para o autor são econômicas, não podem se encontrar nas características próprias dos marginais (incapacidade organizacional ou subcultura). Ao mesmo tempo, com a doutrina desaliana se visa legitimar uma lógica de Estado paternalista e populista, onde se espera que os marginais virem clientes eleitorais desse projeto político.

Paralelamente, a crítica se estende à práxis dos partidos operários tradicionais (principalmente o Partido Comunista), constituídos majoritariamente por trabalhadores não marginais. Esses partidos desenvolveriam uma penetração no mundo popular de caráter economicista apenas reivindicativa. Assim, e devido à fraca penetração ideológica, existiria uma tendência a fortalecer as Juntas de Vecinos (JJVV) como um instrumento de disputa eleitoral. Ao analisar os diferentes níveis de consciência dos pobladores mediante uma tipologia de Alain Touraine, Vanderschueren (1971b) concluirá que, apesar dos esforços mobilizadores da esquerda tradicional, a evidência indicava que não se conseguiu desenvolver uma "consciência hegemônica" (projeto alternativo de poder) entre os pobladores, prevalecendo uma "consciência dependente" (colaboracionista ou que vê possibilidade de mudança apenas de cima para baixo), já que este setor político desenvolveu antes uma política de negação da influência democrata-cristã que uma afirmação da classe própria do setor poblacional. Assim, observava-se 
uma presença mínima de "consciência constituinte" (ou de caráter submisso).

Segundo esses autores, os campamentos eram, para a direita, o espaço de resguardo do lúmpen; para a esquerda operária (comunistas), o principal meio de pressão das massas para obter habitação; e, para a esquerda revolucionária, o primeiro passo para tomada do poder ("nos tomamos este sitio y luego el poder"). Além das interpretações em disputa, o CIDU reconhecia nos campamentos de pobladores uma experiência única de luta política e de organização urbana. $\mathrm{O}$ traço que dotará de originalidade este movimento é que o processo de tomada de terrenos estava fortemente vinculado à questão do poder, não apenas pela presença de organizações populares das mais variadas no interior dos campamentos, mas também pelo papel diretamente político exercido pelo ato da tomada de terreno e pelo processo político experimentado pelo Chile durante o período em que o movimento de pobladores ganha centralidade (finais dos 1960 e começo dos 1970), o que marcará a intervenção diferencial dos diferentes atores políticos nos campamentos (CIDU, 1972).

Para Castells (1972, p. 82), o que caracterizará o movimento de pobladores é a articulação, no marco da luta de classes, da reivindicação urbana e de uma estratégia política ligada à mobilização de objetivos baseados no governo local, o que permitiu o desenvolvimento de novas formas de organização política. Assim, serão três elementos que se fundirão para estabelecer o movimento de pobladores:

Uma forte reivindicação em torno à habitação e ao consumo coletivo em geral; o pertencimento a uma fração do proletariado inserida, em geral, em setores em crise ou de escassa geração de renda; a intervenção de conjunturas e linhas políticas fundamentalmente distribuídas em três tendências, que para simplificar, 
nomearemos como vinculada à Unidade Popular ${ }^{3}$, à esquerda revolucionária e à Democracia Cristã.

O que explicaria a centralidade, mesmo que por sobre a luta operária nas fábricas, da questão urbana nas lutas sociais, em Santiago, no período prévio à eleição de 1970 (na qual terminaria ganhando o socialista Salvador Allende), seria a coincidência tática de três estratégias políticas opostas que concorreram no específico espaço dos campamentos e poblaciones para dar uma saída à crise estrutural da habitação popular no Chile. A primeira destas estratégias é a representada pela Democracia Cristã (DC) que, inspirada na política de promoção popular, era considerada pelo CIDU apenas como uma tentativa populista de inclusão dos operários na sua clientela potencial, mediante a mobilização em torno de uma contradição secundária: a habitação. A segunda era representada pelos partidos operários, notadamente o Partido Comunista, os quais tentavam levar a batalha política ao terreno proposto pela DC visando à campanha eleitoral de 1970. Finalmente, a esquerda revolucionária liderada pelo Movimiento de Izquierda Revolucionaria (MIR), que achou no caráter explosivo das tomadas uma fonte fecunda para alimentar sua estratégia de luta armada, assim como uma chance para penetrar nos setores operários e populares que no mundo sindical eram hegemonizados pelos comunistas e socialistas. Nessa disputa, o tipo e o nível de vinculação dos campamentos à luta política dependerão das características da organização política dominante no campamento. E, embora nos textos do CIDU se evidencie uma preferência pelas estratégias revolucionárias e extrainstitucionais, eles encontraram nos campamentos uma fonte de transformação social diversificada e com enorme capacidade criativa para intervir em diferentes frentes (justiça, produção, consumo coletivo, cultura etc.).

3 Coligação que apoiava o governo Allende. 
Outros autores que também formavam parte do CIDU destacaram como a mobilização do setor poblacional e suas reivindicações urbanas geraram novas formas de "poder popular", outorgando um novo caráter à luta política chilena (QUEVEDO e SADER, 1973). Os pobladores foram capazes de se organizar de tal maneira que conseguiram, em boa parte, suprir o Estado quando este não era capaz de satisfazer as demandas populares. A base do que seria o "poder popular" é a capacidade de opor às instituições vigentes outras instituições alternativas, sendo o exemplo que mais chama a atenção dos autores a experiência de justiça popular dada por formas de autoadministração de disciplina, ordem e segurança dentro dos campamentos.

Contudo, eles reconheciam nas diversas manifestações de poder popular sentidos políticos diferentes e estavam cientes de que se elas se restringissem ao nível reivindicativo, perderiam capacidade de transformação. Por isso, advertiam que o movimento deveria desenvolver uma visão global que as unificasse. Porém, o caráter inovador dessas práticas sociais, pela forma qualitativamente diferente de enfrentar os problemas e as carências dos setores populares, configurava uma tentativa original dos dominados para mudar a natureza da situação de subordinação na qual se encontravam, visando uma posição hegemônica dentro da sociedade para sua classe.

Coerentemente com o dito até aqui, uma das experiências que mais reflexão gerou, entre os pesquisadores do CIDU, foi a Justiça Popular ensaiada no Campamento Nueva La Habana. O interesse, neste caso, era duplo: a ideia de uma Justiça Popular foi considerada, por uma parte desses pesquisadores, como a principal inovação do movimento e como a expressão mais clara do poder popular em construção; por outra parte, Nueva La Habana foi identificado como o campamento modelo do MIR tanto por seu nível de organização quanto pelo seu grau de consciência política. Este último se pode apreciar em algumas das declarações das 
lideranças do campamento no documento "Organización y lucha poblacional en el proceso de cambios: la experiencia del campamento Nueva Habana", publicado em 1972:

O mais importante de tudo isto é que se crie uma consciência política nos companheiros que lhes permita visualizar seus inimigos fundamentais, e quais devem ser suas metas: basicamente, a tomada do poder junto com os trabalhadores. É por isso que temos a obrigação de que cada um destes comitês sem casa - que logo se transformarão em acampamentos - se tornem um meio de poder, através de suas próprias organizações, tais como: sua própria organização de vigilância, de cultura, de saúde, de construção, etc., para incorporar o poblador ao processo [...] A única solução que têm as massas trabalhadoras para obter suas reivindicações é por meio da tomada do poder total (apud PASTRANA e THRELFALL, 1974, p. 85).

Nueva La Habana nasceu em outubro de 1970 como resultado da transferência, a um terreno cedido na comuna de $\mathrm{La}$ Florida, de famílias que tinham participado de três tomadas de terrenos organizadas pelo MIR, partido que rapidamente apostou em transformar esse campamento na experiência mais avançada de sua política poblacional. Nueva La Habana se destacou pelo seu elevado grau de organização interna e de mobilização nas diversas tarefas designadas pelo MIR na luta política nacional.

Foi em consideração a essa exemplaridade que Jorge Fiori (1973a) realizou seu estudo sobre a experiência de autoadministração de Justiça nesse campamento, onde tentou traçar as potencialidades e limitaçóes do processo de Justiça Popular experimentado pelos pobladores de Nueva La Habana. Nesse bairro popular, para o autor, estariam se estabelecendo as bases de uma sociedade futura, sendo, em particular, a experiência de autoadministração de justiça um embrião de uma nova justiça de caráter popular. 
Uma das primeiras medidas do MIR na frente poblacional foi a criação das "Milícias Populares", como uma forma de estabelecer um vínculo orgânico entre o partido e a frente de massas e, ao mesmo tempo, como o principal instrumento para dirigir os pobladores e para organizar a defesa frente à repressão policial. A conquista de um teto mediante um ato ilegal exigia a contraposição de normas próprias, assim como de disciplina e organização, correspondendo às milícias o papel mais importante no autodisciplinamento dos pobladores. Da necessidade de manter um grupo humano disciplinado e coeso é que surge como efeito secundário, segundo Jorge Fiori, a experiência no plano da justiça. Os pequenos furtos, as brigas entre vizinhos, os conflitos familiares, a existência de pontos clandestinos de venda de álcool, eram condenados não como comportamentos desviados em si próprios, mas como ameaças às perspectivas de sobrevivência do grupo e da continuidade da luta. Assim, esses comportamentos se tornam matéria de conscientização política.

Uma vez diluída a possibilidade de repressão, pelo reconhecimento do governo Allende, adicionando alguns inconvenientes de organização interna e de desorientação política, a existência de milícias perdeu sua razão de ser, e estas desapareceram a começos do ano de 1971 no campamento. Será majoritariamente com ex-integrantes das milícias que se conformará a Comissão de Disciplina restituindo a discussão de uma ideia de justiça popular, desta vez orientada ao caráter reeducativo das medidas tomadas em relação a quem violasse algumas das normas do campamento. Um dos castigos, por exemplo, era a leitura dos clássicos do marxismo como forma de reeducação e conscientização do poblador sancionado. Jorge Fiori (1973a, p. 92) descreve essa Comissão como uma espécie de aparato controlador responsável por reunir antecedentes de cada caso, informar às instâncias correspondentes e assegurar o cumprimento das sanções. Este processo não se fará sem contradições, pois na prática a Comissão virou uma espécie de polí- 
cia local: "Produz-se assim um progressivo distanciamento entre a Comissão de Disciplina e o resto da organização e um crescente vazio entre sua ação concreta e o sentido geral que queria dar à ação da justiça". Contradições que levaram finalmente à extinção desta Comissão e que estarão presentes também na conformação do Frente de Vigilância do campamento, instância diretamente vinculada a tarefas mais repressivas.

O caso que mais tensionou a experiência de justiça popular neste bairro foi o estupro, por parte de um operário, de uma das professoras da escola autogestionada pelos pobladores, pois os deixou na disjuntiva de aplicar justiça (e castigo) pelas próprias mãos ou deixar o caso nas mãos da justiça penal, ou seja, na justiça burguesa. A posição hesitante das lideranças do MIR também contribuiu a que a situação escapasse do controle das autoridades do campamento. Embora finalmente o acordo foi entregar o acusado à Justiça ordinária, no campamento, gerou-se, segundo Fiori, um importante debate sobre as nuances e diferenças entre a justiça popular e a justiça burguesa.

Para Jorge Fiori (1973, p. 99), o mérito desta situação residia no fato de a justiça popular se apresentar como um problema de poder, mas que para se realizar e alcançar suas potencialidades deveria transcender as limitadas fronteiras do campamento, uma vez que "as possibilidades de seu desenvolvimento enquanto embrião de uma nova justiça estão dadas justamente por um professivo vínculo - anunciado na experiência vivida e por sua vez provocada por ela entre a experiência pontual e a luta geral da classe trabalhadora pela tomada do poder".

Pastrana e Threlfall (1974), num livro aparecido pouco tempo depois do golpe de Estado, destacarão a contribuição do Movimento de Pobladores na luta política no marco da cojuntura dada pelo governo Allende. Eles salientarão que as tomadas de terrenos não foram a única forma usada pelo Movimento de Pobladores, 
aprofundando em outras duas: a organização em torno do abastecimento e os comandos comunais.

Se a tomada de terreno foi a principal ação coletiva do movimento entre 1970 e 1971, durante o ano de 1972 começa a crescer a organização do abastecimento por parte das camadas populares ante o aumento da inflação, a aparição do mercado negro e a política de desestabilização e desabastecimento promovida pela oposição. Assim, esta forma de organização terá seu ponto alto na paralização patronal de outubro de 1972, permitindo mobilizar setores mais amplos que os campamentos radicais e transformando-se, durante 1973, na principal expressão da luta de classes no frente poblacional, segundo esses autores.

As organizações populares de abastecimento começam a se reproduzir com a criação, por parte do governo Allende, das Juntas de Abastecimiento y control de precios (JAP). As duas tarefas fundamentais das JAPs eram, primeiro, a vigilância contra a especulação e o açambarcamento e, segundo, a organização do abastecimento e a distribuição dos produtos de consumo básico. As JAPs foram organizadas a nível local, segundo uma pauta estabelecida pelo governo que determinava a inclusão de lideranças territoriais das principais organizações locais. O governo da Unidade Popular identificou nas JAPs a forma politicamente mais adequada para amortecer a política inflacionária e conseguir controlar o preço dos produtos.

Para Pastrana e Threlfall, estas organizações tinham a novidade de trazer para o âmbito territorial a luta econômica da classe operária contra os efeitos da inflação crônica, a qual anteriormente só se realizava através da reivindicação salarial no lugar de trabalho e também mediante a pressão no Congresso. Porém, eles também identificaram como principais limitações desta experiência a incapacidade das JAPs para superar sua origem burocrática e verticalista, com exceção das Organizações de Abastecimento Direto 
e dos Almacenes del Pueblo desenvolvidos nos campamentos mais organizados e radicalizados.

A criação dos Comandos Comunales, desde mais ou menos um ano e meio antes do Golpe de Estado, foi a resposta popular dos partidos de esquerda à política de desestabilização gerada pela oposição ao governo Allende. Pastrana e Threlfall a qualificaram como um salto qualitativo na luta pelo poder político desenvolvido pelos movimentos sociais no contexto de agudização da conflitividade entre o mundo popular, o Estado e a burguesia. Os autores destacaram como traço destes Comandos: a vinculação orgânica e política, mesmo que irregular, entre pobladores e movimento operário; a criação de organismos locais de "poder popular"; a superação dos enquadramentos particulares que levavam cada organização popular à mobilização, pois os Comandos Populares respondiam a objetivos mais gerais, não relacionados diretamente com um problema específico de cada grupo. Concretamente:

A coordenação entre as diferentes frações da classe explorada mediante a centralização de suas reivindicações sob um organismo que assumisse a defesa do conjunto de seus interesses de classe; que aquilo fosse sobre uma base territorial, partindo de limites reduzidos, tais como os da comuna ou um setor dela, a fim de que, mediante a combinação desses dois elementos, se conseguisse exercer um poder local, um poder de massas que se levantaria como paralelo ao poder institucional e começaria a impor seus interesses sobre os da burguesia, criando uma dualidade de poderes, base da destruição do poder estatal burguês (PASTRANA e THRELFALL, 1974, p. 18).

Assim foi como começou a se organizar uma série de assembleias em diferentes frentes e organizações que normalmente agiam de maneira separada, tais como um sindicato ou uma JAP começam a se comunicar, intercambiar experiências e se vincular 
organicamente. As organizações sociais com base territorial começam a se ocupar das principais ameaças que sofria o governo à sua continuidade: na área da produção, os Comandos se asseguram que as fábricas não paralisem mesmo sem técnicos; nos bairros populares, se estende a relação direta com as distribuidoras estatais de alimentos e com as indústrias para conseguir a entrega dos produtos mais básicos para a população. As dificuldades geradas pela inflação, o mercado negro e o desabastecimento geraram coordenações inéditas entre operários, pobladores e mesmo camponeses. Os autores também salientaram a capacidade desses Comandos para pressionar o Estado, não nos termos tradicionais de satisfação de necessidades, mas exigindo sua intervenção no sistema produtivo e distributivo em função dos interesses populares.

Porém, do ponto de vista político, a estratégia social da Unidade Popular se centrava na frente sindical com a nomeação de interventores públicos nas empresas e com a criação da Área Econômica de Propriedade Social, onde se vivenciava a luta mais aguda com a burguesia local. Isto contribuiu para enfraquecer a ligação entre as reivindicações de consumo massivo da frente poblacional com as da frente sindical. As demandas do movimento de pobladores apareciam assim como mais secundárias ainda: o próprio fato da demanda por habitação ser dirigida contra o Estado e não contra o setor privado retirava apoio político entre os aliados da esquerda, por serem consideradas demandas que enfraqueciam o governo.

Ao mesmo tempo, Pastrana e Threlfall reconheceram neste ponto uma capacidade diferenciada dos pobladores para evidenciar o caráter de classe do Estado, mesmo com a Unidade Popular no poder. Assim, a prevalência de uma opção pela Paz Social e não pela agudização das contradições fez com que se desapreciasse este tipo de instâncias de "poder popular", onde os campamentos mais radicalizados conseguiam influenciar com mais força o posicionamento político das forças de esquerda: "essas classes e frações 
de classe principalmente mobilizadas no movimento poblacional, nos Cordones Industriais e Comandos Comunales não se transformaram na ponta de lança de uma estratégia política diferente à que predominou no seio da UP" (PASTRANA e THRELFALL, 1974, p. 152). Efetivamente, como para muitos autores da época, o erro do governo da Unidade Popular nas análises sobre os pobladores era identificado com o fato de não impulsionar ou, ao menos, não optar por uma estratégia de construção de poder popular que fortalecesse e aprofundasse o processo de transformação social em curso.

Na descrição do Movimento de Pobladores realizado pelo CIDU parece existir uma simbiose entre este novo movimento e a estratégia política desenvolvida pelo MIR, que, a finais dos anos 1960, tentou disputar a hegemonia do movimento popular com os partidos operários (PC e PS). Aliás, a tática das tomadas de terrenos (em muitos casos também propiciadas pela $\mathrm{DC}$ ) se veria favorecida pela identificação do MIR com a medida, pelo caráter de ação direta, oferecendo, à disposição dos pobladores, o aparato paramilitar do grupo para enfrentar a repressão. A tomada parecia também justificar a necessidade imediata da luta armada defendida pelo MIR. Paralelamente, também o MIR assegurava sua penetração no movimento popular, injetando doses de massividade à sua estratégia política. Em especial, sua inserção no mundo poblacional lhe permitia disputar parte importante da massa operária num campo não hegemonizado pelos partidos operários, como acontecia nas fábricas e nos sindicatos. Serão os campamentos organizados pelo MIR os que concentrarão a atenção destes pesquisadores, que reconhecerão, na tentativa de criar microcomunidades revolucionárias, um salto qualitativo no movimento poblacional (CASTELLS, 1972).

As diferentes intervenções realizadas por atores externos (partidos) nas poblaciones de Santiago, por outra parte, são vistas por Vanderschueren (1971a) como ações que num extremo têm 
por objetivo neutralizar e controlar a pressão popular (pela política de Promoção Popular) e, no outro extremo, estimular a mobilização popular, visando à liberação "real" destes setores populares. $\mathrm{O}$ autor tomará partido por esta última perspectiva, a via mobilizante, que será entendida da seguinte forma:

A mobilização popular implica essencialmente coesionar os dominados - neste caso os pobladores - em torno de seus verdadeiros interesses de classe os fazendo perceber através de uma práxis adequada o sistema sócio-económico como fonte de exploração. É essencialmente uma tarefa de educação política destinada a fazer tomar consciência de seu próprio poder às forças populares fazendo delas a base de apoio de uma alternativa de poder na qual os dominados de ontem sejam os imperantes. (VANDERSCHUEREN, 1971b, p. 68, grifo nosso)

Embora a produção intelectual do CIDU sobre o movimento de pobladores tenha mostrado regularidades e coincidências, não se deve compreendê-la como um pensamento unificado. A constituição deste centro de pesquisa se caracterizou não apenas pela interdisciplinaridade, como nele também conviveram diversas visões políticas e urbanas. Vale lembrar que o próprio Roger Vekemans foi parte dos diretores/fundadores do centro. Mesmo no departamento que desenvolveu a perspectiva mais coesa sobre os pobladores, o Equipo de Estudios Poblacionales, existiam divergências. Uma interessante polêmica foi iniciada por José Luis Fiori a partir de uma leitura crítica do citado texto de Castells sobre $E l$ Movimiento de Pobladores y La Lucha de Clases. Para ele, as novas Teorías Poblacionales, desenvolvidas principalmente no CIDU, não tinham superado completamente as dívidas teóricas deixadas pelas perspectivas da marginalidade. Os novos autores teriam caído num estagnamento acrítico devido a que experimentavam um 
momento extremamente demandante em termos práticos pela intensa politização das poblaciones periféricas.

Os pesquisadores do Movimento de Pobladores, da mesma maneira que os teóricos da marginalidade, não teriam sido capazes de definir de forma precisa e homogênea o objeto de estudo, pelo qual seria difícil formular uma teoria coerente ou um conceito adequado do fenômeno estudado. José Luis Fiori (1973b, p.2) perguntava:

O que têm em comum a proliferação de poblaciones periféricas, a promoção massiva de organizações locais por parte do Estado, a multiplicação conjuntural das tomadas de terrenos e o nascimento de organizações populares de caráter comunal, para responder a problemas de fornecimento ou de defesa da Área Social da economia? E, se existe, qual é o fato que reúne estes fenômenos sob um mesmo conceito?

A concentração dos esforços reflexivos nas poblaciones periféricas e nas práticas organizativas que crescem no interior delas, para o referido autor, não seriam suficientes para comprovar que estes bairros formariam unidades homogêneas de análise, pois os resultados das próprias pesquisas mostrariam precisamente a heterogeneidade delas. Os objetos de análise não se corresponderiam com os objetos reais nem com discursos teóricos coerentes. Assim, por exemplo, o conceito de "universo poblacional" de Castells seria uma espécie de reencarnação do conceito de "mundo marginal", que teria como finalidade homogeneizar o objeto de estudo. $\mathrm{O}$ movimento de pobladores abarcaria, nessa lógica, todo o relacionado com a organização e a politização do velho mundo marginal.

Além do mais, mesmo o conceito de "proletariado em crise" seria uma ficção sociológica e política, usada para caracterizar os campamentos dirigidos pelo MIR, a partir de uma diferença esta- 
tística pouco significativa entre desempregados e operários qualificados dentro de um campamento modelo:

Esta conclusão se evidencia apenas com uma porcentagem mais elevada de desempregados encontrada no campamento Nueva La Habana, e outro de maiores ingressos encontrado no acampamento Bernardo O'Higgins. Com este instrumento na mão, o autor esboça uma tipologia dos outros acampamentos estudados. Constata-se, então, que o núcleo interpretativo funciona apenas nos casos dos acampamentos MIR e PC e mais precisamente nos casos considerados na construção do próprio núcleo. Isto é, o núcleo interpretativo apenas interpreta a si mesmo e a tipologia é só uma descrição apressada de quatro acampamentos 'modelos' (FIORI, 1973b, p. 21).

Outra crítica importante realizada por José Luis Fiori é que a caracterização do Movimento de Pobladores a partir da contradição secundária relacionada com habitação e equipamentos coletivos, que cumpriria o papel de ser o fator dinamizador do movimento e delimitador do universo poblacional, não é um problema comum a todas as unidades residenciais e organizações locais estudadas. Assinala o autor (1973b, p. 19): "mal poderiamos querer, então, reunir dentro de um mesmo pacote Tribunais Populares, Comitês 'Sem Casa', Centros de Mães, etc. Castells parece esquecer seu Universo e seu Movimento, ao discutir a organização de sua Vanguarda”. O movimento até poderia ter nascido pela reivindicação de habitação, mas na prática não seria essa a variável que explicaria sua existência.

Por outra parte, o que os autores, como Castells, compreendiam como Movimento de Pobladores correspondia apenas a uma fração minoritária do hipotético mundo poblacional, a qual se identificava com uma linha política específica, a do MIR: "Para certos autores marxistas, porém, o desejo de valorização de uma 
frente de massas entendida, os têm levado a transformar incorretamente esta frente partidariamente justificável, num grupo social e político autônomo" (FIORI, 1973b, p. 28).

Efetivamente, por um lado, esse grupo de pesquisadores fez importantes contribuições para superar a concepção do movimento de pobladores apenas como um auxiliar do movimento operário, lhe outorgando um status político diferenciado, enquanto setor potencialmente decisivo na hora de resolver a polarização política experimentada pela sociedade chilena durante o governo Allende. Por outro, a discussão teórica sobre o movimento de pobladores que propunham refletia as disputas políticas da época no próprio campo intelectual. Em um momento de extrema divisão no interior da esquerda, esses autores tomaram posição a favor de uma estratégia e de um sujeito: a esquerda revolucionária e os pobladores. Com isso, se sobredimensionou o alcance e o papel do movimento de pobladores ligado à esquerda radical. A acentuada preocupação pela novidade que o movimento apresentava no marco da conjuntura do governo Allende fará com que esses autores percam de vista o processo de conformação como sujeito do próprio movimento previamente. Isso explicará a ausência de análise de experiências anteriores do movimento de pobladores, como a tomada de terrenos da población La Victoria, de 1957, acontecimento considerado por alguns autores como o fato que inicia o próprio movimento (GARCÉS, 2002). La Victoria, neste caso, ficará fora do interesse desses pesquisadores, em parte por estar associada à estratégia poblacional do Partido Comunista, a qual era identificada como uma práxis eleitoreira e economicista, apesar de que, em La Victoria, se anteciparam repertórios de ação coletiva que serão lidos como novidade nos anos 1970 (CORTÉS, 2014).

Porém, é preciso lembrar que o grupo que pesquisou o movimento de pobladores, no curto período que durou o governo Allende, se deparou com uma situação de mudança constante, grande mobilização e extraordinários níveis de organização e par- 
ticipação popular. Teria sido muito difícil para qualquer grupo de cientistas sociais registrar todos esses fenômenos, teorizá-los e, ao mesmo tempo, fazer as conexões históricas correspondentes. Os movimentos sociais no período da Unidade Popular sempre iam mais rápido nas suas dinâmicas, ações e repertórios que a capacidade dos pesquisadores de processá-los.

Por isso, não deveria estranhar que, apesar de ressaltar a importância das contradições no âmbito urbano, a luta dos pobladores, independentemente de sua valoração como um intento original de transformação da natureza da situação de subordinação na qual estes se encontravam, será conceitualizada em termos de consumo (notadamente habitacional). Não há, entre estes autores, pelo menos nos textos publicados na revista $E U R E$, uma valoração específica da importância do espaço para a configuração das contradições sociais e nos desdobramentos dos movimentos sociais. Será preciso esperar até a publicação, em 1972 (primeira edição em francês), de A Questão Urbana de Castells (2008), para ver um esforço sistemático de teorização da variável espaço no contexto da mobilização urbana.

Porém, é preciso consignar que, se teve um autor que ofereceu uma leitura a contracorrente das interpretações dominantes na época, esse foi o sociólogo cubano-americano Alejandro Portes, a partir de sua pesquisa de doutorado, realizada no Chile, no final da década de 1960. Portes (1972) propôs uma teoria da racionalidade do slum oposta à teoria da marginalidade e às perspectivas que viam no movimento de pobladores uma comprovação do radicalismo associado a este tipo de habitação popular. Ambas as interpretações partiam da definição da população do slum como culturalmente primitiva e, portanto, irracional: os pobres urbanos se debatiam supostamente entre a apatia e a tendência à radicalidade. $\mathrm{O}$ pobre seria radical porque é atrasado culturalmente e porque é governado pelo impulso, sendo incapaz de antecipar uma sequência de comportamentos orientados à obtenção de um deter- 
minado objetivo. Os pobres são dominados pela frustração e pelo primitivismo.

Segundo Portes (1969), as teorias do slum cometiam o erro de transformar condições sociológicas (pobreza) e físicas (moradia popular) em disposições psicológicas, imputando às vítimas características distorcidas dos seus vitimários. Assim, ele se dará a tarefa de desmitificar vários dos princípios dessas teorias com um forte respaldo empírico. Mediante a realização de vários surveys, o autor mostrará que as poblaciones estavam longe de ser o último refúgio frente à miséria de uma população recém-chegada à cidade sem capacidade de adaptação e de abrir caminho por si própria. A grande proporção de moradores não era migrante, tinha nascido em Santiago ou morava já há tempo na cidade, mostrando níveis de ingressos maiores que o esperado. Por outra parte, a habitação popular, mesmo precária, oferecia uma promessa de estabilidade futura e de inserção urbana no presente. Os pobladores se mostravam interessados na sua integração estável à estrutura urbana, para tanto, participavam de organizações de vizinhança e cultivavam aspirações sobre seu futuro e confiança no seu logro.

Outro equívoco, para Portes (1971), é compreender o slum como uma unidade homogênea. Não apenas a população que os habita é heterogênea, como é possível diferenciar tipos de habitação popular. $\mathrm{O}$ cubano-americano vai propor uma tipologia a partir de dois critérios: a origem do agrupamento urbano no passado e a orientação dos seus habitantes em relação ao futuro do agrupamento. Assim, slums criados por iniciativa popular ou governamental, por um lado, e os definidos como transitórios ou permanentes, por outro, geram dinâmicas organizacionais e uma relação entre poblador e espaço totalmente diferentes: o cruzamento entre iniciativa popular e transitoriedade originam os slums degradados; iniciativa governamental e transitoriedade, os projetos habitacionais decaídos; iniciativa popular e permanência, as poblaciones; e as iniciativas governamentais permanentes, as poblaciones urba- 
nizadas. São estas duas últimas as que apresentam maior grau de organização e de compromisso com o bairro, enquanto os tipos transitórios apresentam maior desapego e menor progresso.

Particularmente interessante é a visão sobre as poblaciones originadas por tomadas de terrenos. Portes (1971) reconhece que muitas delas foram originadas por uma bem sucedida agitação de militantes com fins ideológicos, mas para a maior parte dos invasores a tomada, mais que uma ruptura, era a única alternativa disponível para a conquista de um teto e seu primeiro e último confronto com a ordem estabelecida. Assim, uma vez estabelecidos, embora possam manter suas simpatias pela esquerda, o que tende a primar é sua intenção de integração à sociedade urbana através da posse segura de um pedaço de terra. O que Portes (1970) pretende mostrar é que não existe uma relação linear entre status econômico (ingresso-educação) e radicalismo de esquerda. Não é a condição de pobres nem sua precária situação o que faz dos pobladores atores manipuláveis em favor de projetos revolucionários. Embora o autor reconheça que a origem social (classe) é politicamente relevante como grupo de referência, é a identificação subjetiva com a classe que pode levar ao radicalismo. Uma situação de privação econômica pode originar explicações individualistas ou imputações estruturais sobre a origem da mesma. Logo, o esquerdismo radical pode estar presente nas poblaciones, porém mais por uma questão subjetiva que estrutural.

A tomada de terrenos, assim como, em geral, a conduta social dos moradores dos slums, é para Portes (1972) o produto de sequências calculadas de ações que buscam concretizar fins realistas. Tanto a participação como a não-participação se dão em função de considerações racionais utilitárias. As organizações de vizinhos ou comitês de sem-teto podem ser instrumentos válidos para serem empregados quando for necessário. O comportamento dos pobladores, assim como o das pessoas em geral, considera os modos mais eficientes de melhoramento de suas posições em relação aos 
limites e as barreiras presentes na sua sociedade. Particularmente o Chile de finais dos anos 1960 e começos dos 1970 era especialmente propício para que iniciativas como as tomadas e as organizações populares representassem uma das formas mais eficientes de integração dos pobres urbanos à sociedade chilena.

Porém, a mesma situação de polarização política da sociedade chilena, assim como o clima intelectual da época que exigia dos intelectuais posicionamentos em relação às mudanças em curso, eram ambientes pouco propícios para a recepção das ideias deste autor. Para além das suspeitas que devem ter existido no campo frente a sua condição de cubano-americano, sua matriz teórica weberiana, assim como suas conclusões que questionavam a existência de um movimento de pobladores radical, postergaram sua figuração no campo acadêmico chileno (nem tanto nos Estados Unidos), embora muitas das suas advertências tenham sido incorporadas nas análises críticas do movimento de pobladores depois do golpe de Estado.

Aliás, nenhuma crítica foi tão avassalante em relação às perspectivas defendidas pelo CIDU como o próprio desenrolar dos acontecimentos que levaram ao Golpe de Estado do General Pinochet, e que não apenas significaram o fim do processo ascendente de lutas e mobilização dos pobladores, como também o início de uma das repressões mais sistemáticas vistas contra movimentos sociais na América Latina. A Ditadura Militar perseguiu os partidos de esquerda organizados nos diferentes âmbitos da vida social: nos sindicatos, no campo, nas universidades e nas poblaciones e campamentos. O movimento de pobladores identificado com estes partidos sofreu um alto grau de repressão tanto de uma maneira seletiva, com a morte e desaparecimento de suas principais lideranças, quanto coletiva, com as invasões policiais, cercos de poblaciones, detenções massivas, sequestros, destruição e roubo de objetos pessoais e domésticos, segundo assinalou o Comité de Memoria Histórica da Corporación José Domingo Cañas (2005). 
Com o desaparecimento dos partidos e de suas lideranças, ao menos inicialmente, o movimento parecia ter também desaparecido. Algo similar aconteceu com a temática poblacional no âmbito acadêmico: o CIDU foi reestruturado, alguns dos seus pesquisadores tiveram que sair do país e a maior parte terminou por abandonar o estudo deste sujeito social aparentemente em extinção política. A revista EURE foi reorientada a outras temáticas do âmbito urbano e o produtivo ciclo de produção teórica sobre esse movimento chegou ao fim. Porém, Manuel Castells continuou refletindo sobre este e outros temas urbanos, tendo como principal objeto de pesquisa o que ele chamou de Movimentos Sociais Urbanos. Categoria que sofreu uma série de transformações e que teve que ser reformulada depois do final trágico do que seria o modelo por excelência da definição feita por este autor. Isso é o que analisaremos a seguir.

\section{A metamorfose do pensamento urbano de Manuel Castells e os Movimentos Sociais Urbanos}

A trajetória intelectual de Manuel Castells e o Movimento de Pobladores estão estreitamente ligados, não apenas pela influência que esse autor teve entre os pesquisadores do mundo poblacional durante sua passagem pelo CIDU no Chile a começos dos anos 1970, mas principalmente porque o conceito de Movimentos Sociais Urbanos, uma das categorias que mais impacto teve na questão urbana, durante muito tempo, ficou associada à experiência desenvolvida pelos pobladores durante o governo Allende, como realização histórica das potencialidades contidas nessa definição.

É no Chile da Unidade Popular, no seio do 'Movimento de Pobladores' que a ligação entre luta de classe, luta urbana e luta política tem sido estabelecida seguindo uma diversidade de situações e orientações nas quais a riqueza permite formular hipóteses em 
relação às condições sociais de articulação entre estes diferentes campos de contradições. (CASTELLS, 1973a, pp. 21-2).

Mesmo no texto mais importante de Manuel Castells sobre urbanismo, A Questão Urbana (2008), esta associação entre definição teórica e caso histórico pareceu ficar selada com a inclusão na edição em espanhol do artigo, anteriormente publicado na revista EURE, sobre "El Movimiento de Pobladores y Lucha de Clases" (CASTELLS, 1972). Porém, a derrota da experiência da Unidade Popular de Allende e, com ela, do Movimento de Pobladores que o autor e outros descreveram, obrigaram a uma revisão profunda do conceito de Movimentos Sociais Urbanos.

Efetivamente, o pensamento urbano de Manuel Castells e, mais especificamente, a ideia de Movimentos Sociais Urbanos experimentaram uma série de metamorfoses entre o começo dos anos 1970 e os anos 1980. Mais que uma autocrítica, a revisão do autor se aproxima a uma negação dos principais elementos constitutivos do que ele entendia por Movimento Social Urbano. Nesse processo, a obra de Castells foi especialmente elástica e sensível aos debates teóricos e políticos experimentados pela esquerda nas duas décadas mencionadas, influenciada inicialmente pelos debates do marxismo estruturalista de Louis Althusser e Nicos Poulantzas, transitando pela novidade do eurocomunismo até chegar à incorporação na sua definição das concepções sobre movimentos sociais desenvolvidas por Alain Touraine.

Na produção teórica urbana de Manuel Castells, não existe apenas uma definição de Movimentos Sociais Urbanos. Da leitura de suas principais obras podem se depreender três definições distintas: Movimentos Sociais Urbanos como nova forma da luta de classes, MSU como via ao socialismo democrático e MSU como utopias reativas. Não deixa de ser interessante que cada uma delas rivalize e negue a outra. Esse dado deverá ser levado em consideração na hora de compreender como as ciências definiram e se apro- 
ximaram ao Movimento de Pobladores e de Favelados, pois boa parte da produção intelectual sobre esses movimentos desde 1970 em diante se fez aplicando ou contestando a ideia de Movimentos Sociais Urbanos.

\section{Movimentos Sociais Urbanos como nova forma da luta de classes}

Esta fase coincide com o período em que Castells trabalhou no Chile estudando o Movimento de Pobladores e com a publicação de $A$ Questão Urbana, obra na qual este autor desenvolve sua tentativa mais ambiciosa de compreensão do urbano desde uma perspectiva materialista.

A Questão Urbana foi publicado originalmente em francês em 1972, e nele o sociólogo espanhol visava reinterpretar a problemática urbana desde a perspectiva do materialismo dialético, para o qual esperava estudar a produção das formas espaciais a partir da estrutura social de base, ou seja, o modo de produção capitalista e os processos e unidades de reprodução social da força de trabalho. Para tanto, empreendeu uma crítica descarnada contra o que ele considerava como o conjunto de teorias sociológicas idealistas sobre o urbano e a cidade, tanto na sua versão de direita, a Escola de Chicago, quanto na sua versão de esquerda, Henri Lefebvre. N'A Questão Urbana, o urbano, mais que um objeto teórico, é um objeto ideológico; logo, a crítica à sociologia urbana toma a forma de uma crítica à ideologia urbana que está oculta nas práticas das classes dominantes para reproduzir a força de trabalho e as relações sociais de produção.

A ideologia urbana é definida por Castells como aquela visão específica que capta os modos e as formas de organização social, característicos de uma fase da evolução da sociedade ligada às condições técnicas e naturais da existência humana e seu marco de reprodução vital, criando, ao mesmo tempo, a possibilidade e a ilusão de uma "ciência do urbano", teoricamente definida pela es- 
pecificidade do seu objeto. O desenvolvimento dessa ideologia estaria associado à perspectiva culturalista que a desenvolveu, reproduzindo um mito da cultura urbana, ou seja, um sistema específico de relações sociais e atitudes (a cultura urbana) que configura um quadro ecológico dado (a cidade).

Portanto, mesmo reconhecendo a existência de especificidades culturais nos diferentes meios sociais, sua postura urbana será eminentemente anticulturalista. Os diferentes "modos de vida" que podem se encontrar no mundo social são inseparáveis da compreensão da estrutura social que os origina, e não se podem depreender automaticamente de uma correlação entre conteúdos culturais e assentamento espacial, tal como era proposto por alguns dos autores da Escola de Chicago em relação à separação campo/cidade.

Esta postura anticulturalista também é aplicável à sua visão de bairro, ou, melhor dito, à sua crítica à ideologia do bairro, que consistiria em tratar formas de vida social como dados naturais ligados a um marco espacial:

Assim, pois, o debate empirista sobre a existência ou não existência de bairros na sociedade moderna, ou sobre a emergência eventual de novos laços sociais nos conjuntos residenciais suburbanos, simplesmente não tem sentido, formulado nestes termos: não se descobrem 'bairros', como se vê um rio; se lhes constrói, se localizam os processos que levam à estruturação ou à desestruturação dos grupos sociais no seu habitar, ou seja, que se integra a estes processos o papel jogado pelo 'marco espacial', o que vem, portanto, a negar o espaço como 'marco' para o incorporar como elemento de uma determinada prática social. (CASTELLS, 2008, p. 4).

O mesmo é válido para o estudo das "subculturas urbanas", nas quais cada grupo racial ou minoritário produziria um determi- 
nado espaço de acordo com seu tipo de comportamento ou cultura. Para o autor, os meios urbanos só podem ser compreendidos como produtos sociais da estrutura, e a relação entre espaço e sociedade deve ser estudada como problemática e não como eixo explicativo da diversidade da vida social. Na ideologia urbana produzida pela sociologia, confunde-se num mesmo discurso a problemática das formas espaciais ligada à reprodução da força de trabalho e a especificidade cultural da sociedade moderna.

Seguindo essa lógica, Castells argumentará que não tem teoria do espaço separada de uma teoria social geral, pois não existe teoria do espaço como tal, mas sim um desdobramento e especificação da teoria da estrutura social, a partir da qual se podem explicar as características das formas sociais e espaciais. Usando como suas principais fontes teóricas a Althusser e Poulantzas, Castells (2008, p. 154) empreenderá a tarefa de prolongar os conceitos fundamentais do materialismo histórico ao campo urbano, sob o suposto de que "analisar o espaço enquanto expressão da estrutura social equivale a estudar sua elaboração pelos elementos do sistema econômico, do sistema político e do sistema ideológico, assim como por suas combinações e as práticas sociais que derivam disso". A pergunta que está por trás deste esforço é: quais são as leis que relacionam espaço e sociedade? Uma primeira tentativa de resposta pode ser encontrada na definição que ensaia de espaço:

O espaço é um produto material em relação com outros elementos materiais, entre eles os homens, os quais contraem determinadas relações sociais, que outorgam ao espaço (e aos outros elementos da combinação) uma forma, uma função, uma significação social. Não é, portanto, apenas uma ocasião de desdobramento da estrutura social, como a expressão concreta de cada conjunto histórico no qual uma sociedade se especifica. Trata-se, portanto, de estabelecer, ao igual que para qualquer outro objeto real, as leis estruturais e conjunturais que regem sua existência e sua mudan- 
ça, assim como sua específica articulação com outros elementos de uma realidade histórica. (CASTELLS, 2008, p. 142).

Dessa maneira, o processo que estrutura o espaço nas sociedades capitalistas é a reprodução da força de trabalho, sendo que as práticas urbanas conotam a articulação deste processo com o conjunto da estrutura social. O sistema urbano corresponde, portanto, à articulação específica das instâncias de uma estrutura social no interior de uma unidade espacial de reprodução da força de trabalho. Mais especificamente:

A cidade é o lugar geográfico onde se instala a superestrutura político-administrativa de uma sociedade que tem chegado a um grau tal de desenvolvimento técnico e social (natural e cultural) que tem sido possível a diferenciação do produto entre reprodução simples e ampla da força de trabalho, e portanto, originando um sistema de repartição que supõe a existência de: 1) um sistema de classes sociais; 2) um sistema político que assegure ao mesmo tempo o funcionamento do conjunto social e a dominação de uma classe; 3) um sistema institucional de investimento, em particular no referente à cultura e à técnica; 4) um sistema de troca com o exterior. (CASTELLS, 2008, p. 19).

Agora, se a estrutura social, tal como é entendida pelo materialismo histórico, não existe sem contradições, ou seja, sem luta de classes, então resulta lógico que a análise da estrutura do espaço exija o estudo da política urbana, a qual para o autor deveria ser o coração da análise sociológica da questão urbana, pois, embora reconheça a existência de leis estruturais tendenciais do fenômeno urbano, este pode ser sempre influenciado e transformado pela prática social. A análise do processo político permitiria compreender a situação concreta e a transformação da questão urbana. A estrutura urbana sofre transformações tanto pelas intervenções do aparato 
público (planejamento urbano) quanto dos movimentos sociais (urbanos), mas essas intervenções estão incluídas na estrutura das contradições que as constituem, logo, a política urbana só pode ser compreendida à luz da luta de classes.

Já que a economia privada é incapaz de satisfazer as necessidades mínimas de habitação e serviços urbanos, a intervenção do Estado, com seus diferentes organismos a nível local e global, se faz necessária permanentemente. A intervenção do Estado na política urbana ou planejamento urbano é uma forma de reorganização do sistema urbano visando à reprodução estrutural do modo de produção, mediante a regulação das contradições não antagônicas, a repressão das contradições antagônicas e a proteção dos interesses da classe social dominante.

Como contrapartida do planejamento, no campo das lutas políticas, estão os Movimentos Sociais Urbanos (MSU), ou seja, as organizações dos agentes sociais que buscam produzir um efeito qualitativamente novo sobre a estrutura social e urbana. As práticas dos MSU podem chegar a modificar a correlação de forças do sistema urbano, entrando em contradição com a dominação social institucionalizada. Na definição de Castells (2008, p. 208):

O Movimento Social Urbano: sistema de práticas que resultam da articulação de uma conjuntura do sistema de agentes urbanos e das outras práticas sociais, na forma tal que seu desenvolvimento tende objetivamente à transformação estrutural do sistema urbano ou a uma modificação substancial da relação de forças na luta de classes, ou seja, em última instância, no poder do Estado.

Os MSUs são um sistema de práticas sociais contraditórias que questionam a ordem estabelecida a partir de contradições específicas da problemática urbana. Ou seja, ativam novas formas de conflito social ligados à organização coletiva do modo de vida, num contexto onde a influência da vida cotidiana sobre a capaci- 
dade produtiva e sobre a vida de trabalho, em geral, é mais decisiva. Tal como Castells (1973b, p. 16) expressava num texto contemporâneo a $A$ Questão Urbana:

Deparamo-nos assim com a exigência social histórica definida por uma série de direitos à vida (habitação, equipamento, saúde, cultura, etc.) arrancados à burguesia e aos aparelhos do Estado e sobre os quais o tratamento social se torna de mais em mais coletivo e interdependente. Eis o que está na base de uma contradição fundamental, já que este conjunto de 'necessidades coletivas' aumenta paulatinamente com a evolução social (também por causas econômicas e pela luta de classes), apesar de que é, em geral, um setor não rentável para investimento capitalista estendido ao consumo, alveja o consumo individual onde a demanda solvente antecipada é muito mais manipulável. $O$ consumo coletivo (habitação, equipamentos, transportes, etc.) viram assim ao mesmo tempo elementos funcionais indispensáveis, objetos permanentes de reivindicação e setor deficitário na economia capitalista.

Os MSUs se apresentam como as verdadeiras fontes de mudança e inovação da cidade, na medida em que representam um desafio à antiga ordem urbana. Além do mais, eles oferecem a possibilidade de ampliar as alianças do movimento operário, aumentando as forças necessárias para gerar transformações profundas na sociedade. A questão dos MSUs implica, por um lado, a análise dos processos sociais de mudança dos modos de consumo coletivo expressadas na organização urbana e, por outro, a articulação entre novas contradições econômicas e políticas próprias da estrutura social. Cada luta urbana deve ser compreendida no seu conteúdo estrutural.

O que está em jogo com os MSUs é a articulação entre lutas urbanas e lutas políticas, no sentido de que uma determinada reivindicação urbana possa se especificar no campo da luta política, 
criando relações novas entre as classes e se articulando com outros planos das relações sociais. Assim, estamos frente a um movimento social urbano quando existe correspondência entre as contradições estruturais fundamentais do sistema urbano e uma linha "justa" de uma organização que é capaz de relacionar essas contradições com outras que põem em questão a dominação.

Uma simples acumulação de reivindicações urbanas, se se expressa sem objetivos de luta propriamente políticos, se transforma num "tradeunionismo do consumo", uma forma de economicismo de corte quase gremialista que não questiona nem o modo de produção nem sua concreção urbana. A articulação entre reivindicação urbana e luta política não opera por si própria; necessita de um elemento externo, uma intervenção organizada que permita a ligação entre a prática política das massas e a luta política propriamente dita.

É precisamente essa articulação e essa intervenção que Castells observou no Movimento de Pobladores chileno. Nesse caso, a própria definição de pobladores fazia mais referência à questão política que espacial, pois o assentamento espacial do movimento tomava diversas formas: callampas, campamentos, poblaciones etc., sendo que a condição de poblador remetia ao pertencimento a um determinado movimento social.

A aparição do Movimento de Pobladores implicou a incorporação às forças revolucionárias de um contingente significativo de população, caracterizada pela aplicação de uma estratégia de habitação "selvagem" dada por tomadas de terrenos ilegais e cujas reivindicações eram de caráter urbano. Os pobladores se transformaram num eixo fundamental das lutas sociais, assumindo, em determinadas situações, maior importância política que o próprio Movimento Operário. Com sua prática política nos campamentos, segundo Castells, esse movimento inaugurou novas formas de luta e mesmo prefigurou transformações futuras das relações sociais prometidas pelas mudanças que experimentava a sociedade chilena. 
Embora Castells tenha estudado outros exemplos de reivindicação urbana na França, em Quebec e nos Estados Unidos, nesse período, nenhuma das outras experiências satisfazia as exigências de articulação entre a luta urbana e a luta política como o caso dos pobladores chilenos. Estes demonstraram que a mobilização em torno a uma contradição secundária de consumo pode chegar a se transformar numa contradição principal em determinados momentos da luta social.

Nossas análises mostram a extrema dependência das lutas urbanas em relação às outras lutas sociais, e até sua incapacidade de desenvolvimento real sem uma articulação com os conflitos políticos que permanecem essencialmente dominados pelas formas atuais de enfrentamento entre Capital e Trabalho. Mas isto não significa dizer que as lutas urbanas sejam necessariamente relegadas ao mundo do reformismo gestionário. Pelo contrário, conseguimos constatar sua importância decisiva em certas conjunturas políticas, já que uma contradição estruturalmente secundária pode ser conjunturalmente principal. Isto signigica que não se poderá julgar a importância política de um movimento urbano sem considerar os efeitos que produzem sobre as relações de poder entre as classes sociais numa situação concreta (CASTELLS, 1973b, pp. 128-9).

\section{Movimentos Sociais Urbanos como via democrática ao socialismo}

Um dos aspectos mais interessantes da obra urbana de Manuel Castells é a ampla variedade de experiências empíricas de movimentos reivindicatórios urbanos estudados. Nesta fase do autor, o caso analisado é o Movimento Citadino de Madri, articulado mais ou menos desde $1974 \mathrm{em}$ plena ditadura franquista, num texto chamado sugestivamente de Cidade, Democracia e Socialis- 
mo (CASTELLS, 1980), publicado originalmente em 1977 na Espanha.

Depois do amargo e trágico final do Movimento de Pobladores chileno, agora o autor parece empolgado novamente com a revitalização das lutas urbanas como forma de politização dos setores populares, mas desta vez de uma forma completamente diferente da experiência andina.

Um novo espectro ronda o mundo em crise do capitalismo avançado. Associações de vizinhos, comitês de bairro, organizações de usuários de serviços públicos, associações de pais de alunos, sindicatos de consumidores, organismos de participação, clubes culturais, centros sociais, toda uma infinidade de expressões citadinas que lutam, organizam-se e tomam consciência, na tentativa de transformar a base material e a forma social da vida cotidiana (CASTELLS, 1980, p. 19).

Mantendo a ideia da existência de três níveis fundamentais dos MSUs, a saber, a relação diferencial com as contradições da cidade, sua inserção na estrutura de classes sociais e sua articulação com a dinâmica política geral da sociedade, o autor tentará mostrar como a evolução do movimento citadino madrilenho esteve estreitamente ligada ao processo político de luta pela democracia, transformando-se num dos principais componentes que permitiram o retorno democrático.

Para ele, isto não era um fenômeno isolado, pois observava a aparição de movimentos similares ao citadino em quase todas as sociedades capitalistas avançadas, virando um dos elementos característicos dessa etapa da dinâmica social. Porém, o caso espanhol apresentava um mérito distintivo: o fato de se desenvolver no meio de uma ditadura de traços fascistoides.

Efetivamente organizado em base a reivindicações "secundárias” - moradia, transporte, segurança na circulação, sanitárias, 
de ensino, de preservação de espaços verdes, de instalações esportivas e de carestia da vida -, o Movimento Citadino madrilenho proporcionou aos vizinhos que o compunham a possibilidade de participar livremente na resolução de seus problemas mais imediatos, apesar dos momentos de intensa repressão franquista. Eles conseguiam na prática o que o franquismo negava oficialmente, mostrando "seu caráter objetivamente democrático, que os transformou em escola de democracia e fator decisivo na luta pela liberdade" (CASTELLS, 1980, p. 81).

Mas o que origina os Movimentos Sociais Urbanos como o Movimento Citadino madrilenho? A resposta de Castells a esta questão está em continuidade com sua obra anterior: a crise urbana provocada pelo capitalismo e a resposta popular. Por um lado, o capitalismo monopolista possuiria uma tendência à crise, expressada agora como crise urbana cada vez mais profunda; por outro, as classes sociais lutam por defender seus interesses frente ao capital e frente ao Estado (repressivo ou negociador de interesses). A crise urbana se produz pela crescente incapacidade do capital de assegurar a produção, distribuição e gestão dos meios de consumo coletivo necessários à vida cotidiana, desde a moradia até as escolas, passando pelos transportes, saúde, áreas verdes etc., transformando a crise em algo mais que uma simples deficiência do sistema. A crise se apresenta como uma consequência da lógica do desenvolvimento capitalista. A concentração do capital gera sucessivas concentrações: econômica, social e espacial dos meios de produção e das unidades de gestão, assim como da força de trabalho nas cidades, provocando uma maior interdependência dos meios de consumo. $\mathrm{O}$ fenômeno anterior transforma o consumo numa dimensão cada vez mais importante; por sua vez, as massas populares começam a ser mais exigentes com a satisfação de suas necessidades. Dessa maneira, 
Aquilo que é exigido pelo sistema em conjunto, mal pode ser atendido por algum capital privado. E é essa a contradição estrutural que provoca a crise urbana: os serviços coletivos requeridos pelo modo de vida suscitado pelo desenvolvimento capitalista não são suficientemente rentáveis para ser produzidos pelo capital, com vistas à obtenção do lucro. Daí nasce a crise urbana como crise de serviços coletivos necessários à vida das cidades. Da impossibilidade do sistema em produzir aqueles serviços cuja necessidade ele suscitou. (CASTELLS, 1980, p. 23).

Essa incapacidade provoca a necessidade da presença do Estado, politizando de fato a questão do consumo.

Mas a intervenção do Estado não constitui um suposto mecanismo regulador neutro aplicado a um sistema em desequilíbrio. É a resultante de um processo político, amplamente determinado pelas lutas de classe. Nesse sentido, os conflitos políticos serão fatores essenciais na gestão dos meios coletivos de consumo e do sistema urbano por eles determinado [...] o Estado se transforma no patrão dos serviços públicos estruturados da vida cotidiana. $\mathrm{E}$ a partir daí, as contradições que se desenvolvem na esfera do consumo coletivo, os conflitos que nascem da organização urbana, tendem a se relacionar, mais ou menos diretamente, com a gestão do Estado e com as orientações políticas subjacentes. De fato, pois, a intervenção do Estado no setor urbano, em vez de superar a crise habitacional e de equipamentos criada pela contradição inerente à urbanização capitalista, politiza e globaliza os conflitos urbanos, ao articular diretamente as condições materiais de organização da vida cotidiana e do conteúdo de classe das políticas do Estado. (CASTELLS, 1980, p. 24).

Madri experimentava essa crise urbana como uma especificação das contradições gerais do desenvolvimento urbano capi- 
talista, mas com a particularidade outorgada pelas contradiçóes políticas próprias de uma ditadura como a franquista. Sem dúvida, o fato de ter se desenvolvido no meio de uma ditadura dava um mérito adicional ao Movimento Citadino, mais ainda conseguindo mobilizar e organizar de maneira estável os moradores que o compunham, impondo na prática o direito de associação e de reunião proibidos pela ditadura. $\mathrm{O}$ movimento permitiu a defesa das condições de vida da população no contexto da crise urbana, promovendo formas de relações sociais mais solidárias e humanas frente às propostas pelo capitalismo e o franquismo. Ao mesmo tempo, complementou a luta do movimento operário, o qual, para Castells, continuava sendo o verdadeiro motor da luta contra a ditadura, ampliando a base social de apoio do movimento democrático. Sendo que também permitiu a reconstrução de uma trama social e de vida associativa nos bairros que tinham sido exterminados pelo terror político.

No estritamente urbano, o Movimento Citadino foi capaz de modificar profundamente as condições de desenvolvimento urbano nas zonas onde se mobilizou, forçou decisões urbanísticas, permitiu o controle dos moradores de planos, modificou a distribuição de equipamentos, assim como alguns planos de remodelação, tudo em um marco de urbanização autoritária que teoricamente outorgava carta branca às autoridades do regime para desenvolver seu modelo de cidade.

Porém, a principal potencialidade identificada por Castells no Movimento Citadino madrilenho era sua possível contribuição para uma via democrática ao socialismo. Surpreendentemente para quem, no Chile, se posicionou mais próximo da esquerda radical que da esquerda democrática, no caso espanhol, o autor defenderá as concepções levantadas na época pelo eurocomunismo, sendo sua principal referência política no texto Santiago Carrillo, Secretário Geral do Partido Comunista Espanhol e um dos ideólogos do eurocomunismo. Caso se considere a via chilena ao 
socialismo como uma das fontes inspiradoras do eurocomunismo (SANTONI, 2010), então se poderia dizer que Castells sofreu de um allendismo tardio na sua compreensão do socialismo e do papel dos movimentos sociais nele. A via democrática ao socialismo se faz com as massas, pelas massas e para as massas; logo, o que a viabiliza é a conscientização da grande maioria dos trabalhadores manuais e não manuais. Eis a importância dos MSUs, pois estes oferecem a oportunidade de que, mediante a prática coletiva de luta e organização, um número maior de cidadãos compreenda seus interesses e as contradições da dominação capitalista. $\mathrm{O}$ caráter interclassista dos MSUs permitiria uma ampliação da base social das lutas anticapitalistas, outorgando às lutas urbanas a condição de componente essencial da via democrática ao socialismo, pois as práticas do movimento que constrói uma cidade mais democrática fazem parte do espírito desse tipo de socialismo. Nas palavras do autor:

Isto é, de um caminho que trata, por um lado, de desenvolver cotidianamente a luta e a organização das massas populares em defesa de seus interesses e como expressão de suas próprias tendências sociais e culturais; por outro lado, de acrescentar a força política da alternativa socialista e de assegurar sua presença nas instituições representativas do Estado em todos os níveis; enfim, de mudar qualitativamente a política e a estrutura desse Estado, articulando-o cada vez mais estreitamente às organizações populares e apoiando-se na força autônoma dessas organizações para modificar a correlação de forças sociais e defender as conquistas que se vão alcançando no seio do Estado e na relação entre o Estado e a sociedade (CASTELLS, 1980, p. 168).

Castells (1980, p. 167) parece mais preocupado com a construção de uma hegemonia popular em termos gramscianos, do que com um assalto ao Palácio de Inverno, o que fica em evidência no 
fato de renegar o MSU como um mecanismo de construção de poder popular:

O perigo das iniciativas necessárias para avançar na direção assinalada de extensão da democracia, é que o movimento citadino seja instrumentalizado em favor de uma estratégia política radicalmente diversa da descrita, que, para simplificar, chamaremos de duplo poder ou de poder popular. Tratar-se-ia, nesse caso, de opor o movimento citadino às instituições democráticas, a democracia direta à democracia representativa, ou, como diriam seus partidários, a 'democracia popular' à 'democracia burguesa'. Tal posição demonstra uma profunda incompreensão do que seja o Estado democrático e das razões históricas do desenvolvimento da democracia representativa, produto da luta de classes e conquista popular contra a burguesia.

Talvez seja esse traço de negação do "poder popular" o elemento que mais distancia de um primeiro Castells, que identificava na experiência poblacional do Movimento de Esquerda Revolucionária chilena e seus campamentos revolucionários a expressão mais avançada dos MSUs. Porém, o autor ainda reivindicará o papel distintivo dos partidos políticos na construção dos MSUs, principalmente a partir da análise do trabalho de massas do Partido Comunista Espanhol na consolidação e desenvolvimento do Movimento Citadino. A politização que caracteriza um MSU torna quase inevitável a intervenção de um agente externo, porém isso o confronta com a ameaça permanente de perda da autonomia e do raio de alcance de sua própria política.

A subordinação orgânica e política de muitas associações às organizações dos partidos foi uma consequência quase necessária da politização imediata do movimento citadino, pelas condições de repressão em que se desenvolveu, principalmente em Madri, 
assim como pela urgência das tarefas políticas na luta contra a ditadura. Mas o fato de que a utilização política direta das associações de vizinhos fosse explicável e difícil de evitar não diminuiu as consequências produzidas no movimento citadino, no sentido de acentuar seu caráter vanguardista e de frear consideravelmente sua representatividade social. (CASTELLS, 1980, p. 150)

A própria existência do Movimento Citadino representava um desafio à ditadura franquista, e uma das suas primeiras lutas foi por sua própria existência legal. Assim, mesmo tendo uma origem claramente reivindicativa, sua luta nasce politizada e logo fica associada à exigência de liberdades democráticas. $\mathrm{O}$ movimento foi reprimido, perseguido e em mais de uma ocasião teve que se enfrentar com a polícia. Portanto, a conclusão de que era necessário um Estado democrático para o desenvolvimento pleno do movimento associativo se espalhou facilmente entre os membros do movimento. A preocupação do autor com o "tradeunionismo" urbano como um desvio dos MSUs já não está presente, porque a reivindicação urbana num contexto autoritário é inseparável da questão política:

Nesse sentido, o movimento citadino não é mais nem menos reformista que o movimento operário, em princípio e em termos estruturais. Porque tudo depende da maneira como for articulada a luta política [...] $\mathrm{O}$ fator determinante não é a fábrica ou o bairro, são as relações políticas entre as classes, em particular aquelas vinculadas ao processo de ocupação-transformação do Estado. E, desde esse ponto de vista, os movimentos urbanos desempenham hoje, na Europa ocidental, um papel decisivo na construção de um novo bloco histórico das classes populares, que torne possível o desenvolvimento da via democrática para o socialismo. (CASTELLS, 1980, p. 33) 
Da mesma maneira, a anterior postura anticulturalista do autor desaparecerá nesta fase. Observar-se-á assim uma valorização do feminismo como forma de transformação radical das relações sociais que começa desde uma base residencial. Assim como também superará sua visão negativa da crítica ecologista, compreendida n'A Questão Urbana como uma forma de "scoutismo", agora entendida como uma experiência cotidiana que oferece a possibilidade do questionamento da lógica capitalista dominante.

No cotidiano do Movimento Citadino, o valor de uso começa a substituir o valor de troca como norma básica e a cidade começa a ser reivindicada como um modo de vida. E essa "descapitalização da sociedade capitalista a nível cultural pode ser potencialmente um instrumento de subversão e de transformação se for levada a cabo a necessária mediação política considerando a correlação de forças e a estratégia adequada no âmbito do estado" (CASTELLS, 1980, p. 37).

Nesse sentido, a diversidade do Movimento Citadino não é um sinal de fraqueza, mas sim de ampliação de sua esfera de influência como forma de interclassismo que possui uma comum oposição à lógica de um desenvolvimento urbano orientado pelo capital; embora o interclassismo não implique uma pulverização da classe, considerando a existência da segregação urbana, a qual provoca a existência de zonas mais homogêneas dentro da cidade, cuja luta fica marcada diferencialmente pelo setor social majoritário que a caracteriza.

Outra dimensão que aparece reabilitada em relação a sua obra anterior é a do bairro. Castells (1980, p. 80) identificará como fundamental a relação entre a luta reivindicatória e a vida social do bairro para a consolidação do Movimento Citadino.

Lá onde existe uma forte solidariedade entre os vizinhos, o movimento reivindicatório pôde-se desenvolver e organizar rapidamente, sendo particularmente significativo, nesse aspecto, o mo- 
vimento dos favelados, ao mesmo tempo comunidade de base, instrumento de luta e órgão de participação política. É interessante que a relação também funcione em sentido inverso: o desenvolvimento da luta, a criação de associações de reivindicação, cria laços sociais onde antes imperava o individualismo; tende a substituir o anonimato e a impessoalidade por uma trama social e uma série de atividades que modificam, pouco a pouco, a vida cotidiana das pessoas. É assim que a luta por um novo tipo de cidade torna-se cada vez mais inseparável da luta por um novo tipo de vida social.

O Movimento Citadino, por um lado, permite o surgimento de novos valores sociais e de novas formas urbanas e, por outro, se torna decisivo na luta pela democracia, impondo a liberdade de associação na prática, legitimando o protesto e a organização dos moradores dos bairros. Em certa medida, antecipava a forma de democracia exigida nas ruas, pois a aplicava na sua própria organização e na gestão do espaço urbano.

\section{Movimentos Sociais Urbanos como utopias reativas}

A publicação de La Ciudad y Las Masas (CASTELLS, 1986), cuja primeira edição foi publicada em inglês em 1983, representa um dos projetos teóricos mais ambiciosos de Manuel Castells, comparável em certa medida com A Questão Social, mas sem o mesmo impacto e com mudanças significativas em relação às teses propostas na primeira fase do pensamento urbano do sociólogo espanhol. Em La Ciudad y Las Masas, Castells visa a construção de uma teoria da mudança social urbana onde o núcleo central são os MSUs, mantendo sua preocupação sobre a análise da estrutura, mas integrada aos processos de crise e mudança que o modificam. Ao mesmo tempo, manterá bastante continuidade com a fase dos MSUs como via para o socialismo democrático, porém com uma 
visão muito mais restrita do alcance destes tipos de movimentos, que serão entendidos como projetos utópicos de caráter reativo, mas que conservam um potencial transformador.

Longe do marxismo estruturalista que originalmente o inspirou, neste texto, o autor ampliará largamente o leque de autores com os quais dialoga: Tilly, Melucci e Touraine, sendo especialmente este último autor o que mais marcas deixou na nova compreensão que Castells vai propor no texto. Particularmente em relação a Poulantzas, marcará distância do seu conceito de formação social, de que toda sociedade é uma combinação de diferentes modos de produção sob o domínio de um deles, mostrando preferência pela ideia de processo histórico:

Porém, seria errado analisar o problema apenas sob este enfoque [de formações sociais], pois uma vez que uma sociedade dada está estruturada, se admitimos que a combinação que subjaz à sua estrutura é única, também o serão sua evolução, sua dinâmica, suas lutas, sua mudança. Logo, não estamos frente a formações sociais, mas frente a processos históricos. (CASTELLS, 1986, p. 416).

Sua tentativa será não a construção de uma teoria transistórica da sociedade e sua especificação da questão urbana, mas sim uma história teorizada dos fenômenos sociais. Para tanto, mobilizará uma quantidade impressionante de casos de MSU de diferentes partes do mundo.

Conservando a ideia original da crescente importância do consumo coletivo através dos serviços urbanos e da incapacidade do capital privado de responder a essas exigências, e obrigando a intervenção sistemática do Estado nos problemas urbanos, que dá a eles uma centralidade nos conflitos políticos contemporâneos, são algumas de suas proposições básicas: 
- A cidade é um produto social resultante de interesses e valores sociais em disputa.

- As principais inovaçóes da cidade geralmente se originam pela mobilização e exigências das massas populares; quando estas conseguem modificar a estrutura urbana, estamos ante a presença de MSU.

- Porém, a estrutura urbana também é criada pela ação dos interesses dominantes e deve ser considerada para sua compreensão.

- Portanto, a ação dos MSU não é única causa da mudança social urbana; existem outras como a função autônoma do Estado, a relação entre sexos, os movimentos étnicos e nacionais e os movimentos citadinos.

A valorização, neste último ponto, do papel das relações de sexo ou dos grupos étnicos na produção do espaço já permite identificar a influência de Alain Touraine nesta nova fase teórica de Castells. O significado do urbano pode mudar pela primazia da experiência urbana como valor de uso, como é proposto por alguns dos Novos Movimentos Sociais, em contraposição ao valor de troca priorizado pelo capitalismo.

Os MSUs seriam, mais especificamente, ações coletivas conscientemente destinadas a transformar interesses e valores incorporados nas formas e funções de uma cidade dada, sendo sua proposta uma nova relação entre espaço e cidade. As fontes dos MSUs seriam movimentos de protesto urbano, mobilizados: por demandas de consumo coletivos, pela defesa de uma identidade cultural associada a um território específico ou por demandas políticas em relação ao governo local. Nessa constelação, os MSUs seriam agentes da mudança social, mas com restrições:

Nossa principal proposição é que existe uma conexão íntima entre os temas, objetivos e experiências dos movimentos sociais ur- 
banos, e o processo global do conflito histórico e a mudança em nossas sociedades. Não é que os movimentos urbanos sejam os novos atores históricos que criam a mudança social, nem a fonte essencial das formas sociais alternativas. $\mathrm{O}$ que afirmamos, mais bem, é que os movimentos urbanos não são expressões aleatórias de descontento que variam de uma cidade a outra, mas que na sua estrutura e seus objetivos, portam os estigmas e projetos de todos os grandes conflitos históricos de nosso tempo. (CASTELLS, 1986 , p. 429).

Os MSUs já não aparecem com uma nova forma de luta de classes ou de qualquer outro tipo (gênero ou étnica). Possuem uma base não classista, são socialmente diversos. São atores urbanos definidos por seus objetivos e por sua condição urbana, e podem aspirar a: (1) conseguir organizar os residentes de uma cidade em função de seu valor de uso, em contraposição à mercantilização da experiência urbana (como valor de troca), o que Castells denomina "sindicalismo de consumo coletivo"; (2) a busca da identidade cultural ou a defesa de uma cultura local autônoma, o que o autor chama de "comunidade"; (3) enfim, o movimento "citadino" que luta pela conquista do governo local, descentralização dos bairros e autogestão urbana. Os MSU são portadores de um conceito alternativo de cidade. De modo resumido:

Assim, a experiência observada dos movimentos urbanos aponta para um significado urbano que representa a alternativa à cidade que surge dos interesses e valores da classe dominante. A cidade alternativa é, portanto, uma rede de comunidades culturais definida pelo tempo e o espaço, autogestionada politicamente olhando à maximização do valor de uso para seus residentes. Este novo signigicado urbano não é nem a imagem ideal nem o sonho de uma noite de verão: é o conjunto de objetivos que nasce da prática dos movimentos urbanos que temos observado, e seu significado 
e existência não são contraditos pela quantidade de dados secundários conhecidos sobre outros movimentos urbanos de outras cidades e outras sociedades [...] Os movimentos são projetos de cidade, vida social, e funções e formas urbanas (predeterminadas pelo significado urbano) que surgem da capacidade dos pobladores urbanos para produzir e controlar seu entorno, seu espaço e seus serviços urbanos (CASTELLS, 1986, p. 432).

Os MSUs são uma reação à "cidade selvagem" como expressão espacial de uma estrutura não reconhecida que produz exploração, alienação e opressão. A expressão material e espacial das formas de urbanização selvagem experimentada pela sociedade provocam reações que contêm o germe da mudança social. Porém, os MSUs não são agentes da mudança social estrutural, mas se expressam como sintomas de resistência à dominação social mesmo nesse processo, chegando a ter efeitos importantes nas cidades e, por extensão, nas sociedades. Apesar da proposta de cidade alternativa implícita na existência dos MSUs, esta é uma utopia restrita sem capacidade de modificação real da estrutura social. Esses movimentos estariam condenados a cumprir um papel reativo e defensivo pela sua incapacidade de promover um projeto histórico viável de produção econômica e social. A estrutura social está fora do alcance das comunidades locais, e as explosões urbanas carecem de instrumentos e capacidade para propor uma reorganização da produção, do consumo e da circulação. Segundo a explicação de Castells (1986, p. 439):

Como todas estas fontes potenciais de conflitos em nossa sociedade não têm meios autônomos de expressão, organização e mobilização, têm se unido de uma maneira negativa e reativa na forma de movimentos urbanos. Quando são reações unidimensionais primitivas, ganham a forma de protesto urbano. Quando têm desenvolvido uma visão global alternativa, formam uma con- 
tracultura, e se sentem mais cômodas se definem sua alternativa num território: propõem uma organização social alternativa, um espaço alternativo, uma cidade alternativa. Viram um movimento social urbano. Mas esse movimento não pode ser 'proativo', apenas 'reativo', exceto na sua dimensão utópica. Mas não podem ser um movimento social, apenas o sintoma de um limite social, pois a cidade que projeta não está nem pode estar conectada a um modo alternativo de produção e desenvolvimento, nem a um Estado democrático adaptado aos processos mundiais de poder. Os movimentos sociais urbanos estão, pois, orientados a transformar o significado da cidade sem poder transformar a sociedade. Eles são uma reação, não uma alternativa: reclamam uma profundidade de existência, sem ser capazes de criar uma nova cultura. Projetam o perfil do mundo que desejam, sem saber por que, nem como, nem se é possível. Quando as instituições permanecem isoladas ou insensíveis, os bancos mantêm seus altos tipos de juros, a polícia volta a ocupar as ruas, o espaço significativo continua se desintegrando, e os movimentos sociais urbanos não propõem já uma cidade alternativa. Em vez disso, seus elementos fragmentados empreendem a destruição da cidade que os rejeita. Observamos e analisamos sua esperança de uma nova sociedade, tal e como se projetava no espaço que desejavam e na cidade que queriam. Mas se tais apelos não são ouvidos, se as vias políticas permanecem fechadas, se os novos movimentos centrais (feminismo, novo movimento operário, autogestão, comunicação alternativa) não frutificam plenamente, então, os movimentos urbanos - utopias reativas que tentaram iluminar o caminho que não podiam percorrer - voltarão, mas desta vez como fantasmas urbanos, dispostos a incendiar as muralhas hostis de sua cidade cativa.

Embora o marxismo estruturalista já não seja a principal fonte teórica neste texto, a força da estrutura, o peso do modo de 
produção aparece como uma instância inatingível pela agência dos MSUs ou de qualquer outro movimento. $\mathrm{O}$ voluntarismo otimista das fases anteriores dos MSUs desaparece neste ponto; nem o Movimento de Pobladores chilenos fez a revolução, nem o Movimento Citadino madrilenho abriu o caminho para um socialismo democrático. Sem dúvida, Castells apostou muito nos MSUs, que considerou como exemplares, e seu estudo durante seu processo de desenvolvimento, sem conhecer seu desenlace, o levou a exagerar o potencial transformador de suas práticas. Em La Ciudad y Las Masas, o processo é inverso, amplia sua definição, permitindo a classificação de um maior número de experiências como MSU, mas limita o alcance e o potencial deles. Por isso, resulta sumamente ilustrativa a avaliação que o autor faz no texto do próprio Movimento de Pobladores chilenos para mensurar o grau de mudança experimentado na concepção de MSU proposta por Castells nesta etapa.

No extenso capítulo que Manuel Castells dedica à América Latina em La Ciudad y las Masas, os MSUs aparecem como subordinados ao que ele chama de populismo urbano. As diferentes tentativas de superação da condição de dependência dos países latino-americanos tiveram como consequência a criação de uma nova relação entre o Estado e as massas populares, caracterizada pela subordinação das últimas sob a forma do populismo urbano.

Por populismo urbano entendemos o proceso de estabelecimento da legitimidade política baseado numa mobilização popular sustentada pela provisão de terras, habitação e serviços públicos, e encaminhada, por sua vez, a obter-los. Este é um mecanismo muito tradicional que existe em numerosos países desde longo tempo, mas sua importância quantitativa e seu significado qualitativo têm-se visto intensificados nos últimos anos pelo ritmo 
e as formas de urbanização nas sociedades dependentes. (CASTELLS, 1986, pp. 245-6)

Incorporando a literatura em voga na época sobre populismo na América Latina, o autor definirá a existência de uma dialética entre a integração social e a mudança na relação entre Estado e pobladores. Embora salientando a condição de subordinação das massas populares às diferentes formas de clientelismo urbano, reconhecerá, nesta nova relação, a possibilidade de desencadeamento de MSUs autônomos. Sem cair na ideia de "massa de manobra" da literatura sobre populismo, principalmente graças à incorporação das noções de Anthony Leeds sobre este tema, Castells mostrará como algumas das tentativas de controle dos pobladores na América Latina tiveram o efeito contrário de ativar movimentos com força e agenda própria. Nos termos do autor:

A substituição de uma relação de patronazgo clássica - entre classe governante e setores populares - por uma mobilização populista controlada, amplia a hegemonia da classe governante sobre esses setores, que são organizados sob a etiqueta de 'marginais urbanos. Mas a crise de tal hegemonia, se se produz, tem consequências muito mais graves para a ordem social existente que a ruptura dos vínculos de patronazgo tradicionais de uma maquinaria política (CASTELLS, 1986, p. 273).

Na América Latina, a urbanização acelerada e a nova divisão internacional do trabalho [...] propiciaram o surgimento de um populismo urbano no qual os pobladores ofereceram sua adesão política e sua heteronomia cultural em troca de serviços urbanos e do direito de se instalar nas margens do sistema econômico mundial. Os movimentos seguiram uma pauta contraditória de reivindicação, negociação, mobilização e integração, ligada ao 
destino dos atores políticos em que sempre se apoiaram os ocupantes ilegais (CASTELLS, 1986, p. 438).

Precisamente um caso de movimento autônomo é o dos pobladores de Santiago do Chile, experiência da qual o autor fará uma avaliação extremamente crítica. Para começar, a presença de partidos políticos, que anteriormente foi celebrada pelo autor por politizar o movimento e por lhe outorgar uma centralidade conjuntural pela coincidência táctica de estratégias políticas diferentes, agora é compreendida como um dado negativo.

Cada campamento dependia da linha política do dirigente fundador, o que tornava os bairros politicamente homogêneos, sem pluralismo. Da mesma maneira, a participação no processo político de cada campamento dependia da linha política dominante, logo não teria existido um "movimento de pobladores", mas ramas de pobladores de cada partido em disputa. Embora os pobladores tenham sido bem sucedidos na transformação do sistema urbano, a possibilidade de geração de novas práticas locais, de fato, estava limitada pelas instituições políticas ainda dominantes. Os partidos políticos, na verdade, utilizaram os pobladores em função dos seus interesses particulares, reduzindo o nível de participação das bases sociais. Castells (1986, p. 433) manterá a ideia de necessidade da politização, mas descartará o papel dos partidos políticos nesse processo:

Uma condição sine qua non: embora os movimentos sociais urbanos tenham que estar conectados com o sistema político para alcançar, ao menos em parte, seus objetivos, devem ser autônomos, desde o ponto de vista de sua organização e de sua ideologia, em relação a qualquer partido. A razão é que a transformação social e a luta política, a negociação e a gestão, embora estejam intimamente relacionadas e sejam estreitamente interdependentes, não operam no mesmo plano da estrutura social. 
Os MSUs na América Latina, mesmo no caso chileno, aparecem subordinados ao sistema político. Este seria o custo da conquista de serviços urbanos e da oportunidade de construir comunidades culturais de caráter popular. A própria vulnerabilidade dos ocupantes ilegais das tomadas de terreno os fazia dependentes do sistema político: sem apoio político, sem a tolerância do Estado, a presença física dos pobres urbanos na cidade estava em questão. Embora os MSUs tenham conseguido mudar as formas urbanas, ficaram dependentes da sorte das suas lideranças políticas, tal como teria acontecido no Chile: quando os partidos que animaram e dirigiram o movimento foram derrotados, o movimento de pobladores desapareceu junto com eles.

Este teria sido o caso até de Nueva La Habana, o campamento modelo da esquerda radical e outrora a corporização histórica dos MSUs como nova forma da luta de classes. Baseando-se no excelente trabalho de Christine Castelain (1975) sobre este bairro, no qual detectou uma significativa brecha ideológica entre a vanguarda política de militantes do MIR e os pobladores, gerando uma contínua tensão dentro do campamento nos seus três anos de existência, Manuel Castells revisitará boa parte de suas ideias sobre esse tópico.

O elevado nível de politização e consciência não era atributo do campamento, mas apenas das lideranças ligadas ao MIR e, embora fosse possível apreciar uma consciência coletiva e simpatia com a política de esquerda, parte importante dos pobladores cultivava uma atitude individualista e utilitarista em relação à política habitacional do Movimento de Pobladores.

Nueva La Habana não se negou a contribuir à parte que lhe correspondia na mobilização nem cultivou uma atitude hipócrita em relação aos ideais socialistas em troca do patronazgo urbano. Porém, o que estava claro para todos os observadores era que essa luta era um meio, e não um fim, para imensa maioria dos pobla- 
dores, que Nueva La Habana era uma comunidade introspectiva que sonhava com uma barriada pacífica, tranquila e bem equipada, enquanto os dirigentes do MIR, conscientes da agudização do conflito político, desejavam elevar o nível de militância de maneira que todo o acampamento virasse uma força revolucionária. Seus esforços desdobrados nessa direção resultaram inúteis (CASTELLS, 1986, p. 285).

Se os pobladores instrumentalizaram a política do MIR para conseguir habitação, por sua vez o MIR utilizou a massa de pobladores em função de sua política nacional na conjuntura específica da polarização prévia ao golpe militar. Houve uma utilização recíproca, mas com significativas consequências para a organização urbana da cidade de Santiago do Chile.

A mobilização geral de outubro de 1972 contra a ofensiva conservadora no Chile deu um novo papel ao acampamento; primeiro, na batalha pela distribuição, e mais tarde, no apoio à construção de cordões industriais (comitês industriais) e comandos comunais (sindicatos urbanos) como centros de poder popular revolucionário. Num gesto favorável a esta estratégia, os militantes de Nueva La Habana tentaram ocupar, em 3 de abril de 1973, o Organismo Nacional de Distribuição Comercial (CENADI), levantando barricadas na principal avenida de Santiago, Vicuña Maskena, e fazendo frente furiosamente à polícia durante todo um dia. Por causa disso, Nueva La Habana manteve sua função subordinada de ramo de um partido político, adotando diversas táticas, segundo as diferentes orientações tomadas pela atividade política do MIR. E assim, se o 'campamento modelo' foi uma expressão da capacidade militante dos ocupantes ilegais para construir sua cidade e ensaiar novos modos de vida comunais, foi também, acima de tudo, uma arma de organização de um partido. (CASTELLS, 1986, p. 289) 
Todavia, o autor não negará a condição de MSU do Movimento de Pobladores, pela mobilização de massas populares em função de questões urbanas e pela contribuição política ao impulso da mudança social. Efetivamente, com o Movimento de Pobladores, os setores urbanos populares, antes passivos, foram protagonistas da cena política nacional. Até poderia ter sido potencialmente decisivo na transformação revolucionária da sociedade, mas não conseguiu projetar uma aliança estável e hegemônica com o movimento operário e com outras capas sociais subalternas. Embora os partidos políticos de esquerda no Chile tenham compreendido essa potencialidade, combatendo as tendências populistas no seu seio, ao mesmo tempo, sobrepolitizaram-no, socavando a unidade do movimento e a definição autônoma dos seus objetivos. O Movimento de Pobladores virou um amplificador das divisões ideológicas da esquerda chilena. Assim, no momento de maior fragmentação da esquerda prévio ao golpe de Estado, cada campamento se alinhou com a tendência correspondente à sua força hegemônica $\mathrm{e}$ o movimento deixou de ser uma entidade identificável: "a desaparição do movimento de pobladores em 1972-73 foi a consequência da lógica da disciplina de partido, que veio a substituir as tentativas da esquerda de estabelecer a hegemonia política de forma unitária sobre o conjunto do movimento" (CASTELLS, 1986, p. 291).

Quando a esquerda ainda estava unida, no começo do governo Allende, os pobladores participaram massivamente da arena política com bandeiras comuns, multiplicando sua capacidade para produzir um novo sistema urbano. Contrariamente ao que pensava em $A$ Questão Urbana, é esse momento o que expressou a maior potencialidade do Movimento de Pobladores como movimento de massas e movimento social; porém, o Movimento de Pobladores teria sumido na polarização da luta política posterior.

O que caracterizaria os pobladores seria sua heteronomia. Ou seja, a capacidade de agentes externos de definirem a orientação do próprio movimento seria ao mesmo tempo sua principal 
fraqueza, pois os faria extremamente dependentes da particularidade das situações políticas que lhes corresponderia enfrentar como movimento. Tal como sintetizou Castells (1986, p. 296):

A heteronomia social dos pobladores, sua localização, sua ênfase na comunidade e a territorialidade, não são sintomas de um tipo especial de personalidade psicológica. Sua dependência do sistema político se encontra no próprio miolo de sua condição social. Sua falta de identidade como movimento social é a expressão direta de sua experiência, de sua incapacidade de encontrar vias de protesto alheias à proteção das forças políticas existentes. Ao perpetuar sua relação com o Estado e ampliar seus assentamentos a um ritmo crescente, os invasores ilegais vêm a ser a força impulsora na produção social da forma urbana denominada cidade dependente; uma cidade onde a maioria dos trabalhadores devem tomar sob sua responsabilidade uma proporção substancial da reprodução de sua própria força de trabalho; onde, para isso, o Estado tem que obviar suas próprias regras institucionais; onde, para conseguir essa tolerância, os pobladores devem achar protetores poderosos que os acolham, e onde a forma urbana resultante degenera numa constelação inarticulada de funções e lugares, relacionados mediante redes invisíveis com os mecanismos subjacentes dessa dinâmica urbana, desde a tecnologia do transporte imposta pelas multinacionais, até as pautas de invasão de terrenos programadas por urbanizações ilegais. 


\section{Capítulo 4 \\ RiO DE JANEIRO, CETICISMO ACADÊMICO \\ E RACIONALIDADE FAVELADA}

Como foi compreendido o movimento favelado do Rio de Janeiro pelas ciências sociais nas décadas de 1970 e 1980? Essa é a pergunta que guiará o presente capítulo, mas para tentar respondê-la é preciso considerar o contexto geral de discussão da questão urbana no Brasil.

Embora sem apresentar um nível de unidade intelectual como a do CIDU chileno, no Rio de Janeiro elaborou-se uma perspectiva analítica contrária à dos MSUs. Autores como Carlos Nelson Ferreira dos Santos, Lícia Valladares e Renato Boschi afirmaram a existência de uma racionalidade utilitária como traço principal do que se poderia entender como Movimento Favelado. Esse grupo assinalará as limitações da ação coletiva urbana e apresentará o caso do Movimento Favelado carioca como a demonstração empírica de que não existem Movimentos Sociais Urbanos, ao menos na maneira como Manuel Castells os definia.

Porém, para compreender esta perspectiva analítica é preciso traçar uma série de continuidades e rupturas entre esses autores e a tradição de pensamento urbano e social brasileiro desenvolvido desde finais dos anos 1960. Não se pode entender o posicionamento anti-MSU sem considerar seu antecedente direto: a crítica à teoria da marginalidade produzida no Rio de Janeiro por autores como Antonhy Leeds, Janice Perlman e Luiz Antônio Machado. Esses autores indicaram a existência do que se poderia 
entender como uma política pragmática dos favelados, sendo este traço um dos principais sustentos de oposição ao sobredimensionamento do potencial político dos pobres urbanos proposto pela escola dos MSUs.

O que será valorado é a racionalidade política dos favelados para instrumentalizar o sistema político, buscando seja benefícios pessoais ou comunitários, mas sem derivar deste traço uma radicalidade per ser ou um potencial transformador inerente. Aliás, mais bem desconfiando das leituras otimistas que identificavam os novos Movimentos Populares Urbanos e as ações diretas espontâneas nos "quebra-quebras" com uma promessa de mudança social corporificada num novo ator social revolucionário.

$\mathrm{O}$ ceticismo em relação à marginalidade se transferiu para a teoria dos MSUs e sua noção dos pobres urbanos como sujeitos potencialmente transformadores do social. Porém, a crítica carioca aos MSUs não se deu apenas mediante a polêmica direta com os fundadores desta escola de pensamento - me refiro a autores tais como o já citado Castells (ver capítulo 3), Jean Lojkine (1979) ou Jordi Borja (1975). A elaboração desta crítica também foi realizada através de um diálogo fecundo e controverso com os principais receptores deste pensamento no Brasil, a maior parte deles oriundos de centros de pesquisa paulistas.

Assim, para fazer um paralelo com o debate chileno de começo dos anos 1970: enquanto em São Paulo a penetração da noção de MSU foi tal que o próprio Castells (2008) reconhecerá, na edição em espanhol da sua $A$ Questão Urbana, que o grupo de pesquisadores paulistas estava dando continuidade às suas elaborações sobre as experiências populares urbanas em sociedades dependentes que foram interrompidas pelo golpe de Estado no Chile; no Rio de Janeiro, por outro lado, a tendência dominante se identificou na prática muito mais com as contribuições de Alejandro Portes (1979), tanto pela distância que tomou das in- 
terpretações que mostravam a radicalidade popular como pela afirmação de uma racionalidade poblacional (MILLÁN, 2013).

As ciências sociais brasileiras foram testemunhas de um debate denso e enormemente produtivo no âmbito urbano que coincidiu com uma polarização do campo em torno do eixo Rio de Janeiro-São Paulo na década de 1980, sendo os principais lugares e meios deste intercâmbio acadêmico o grupo de "Lutas Urbanas, Estado e Cidadania” da Associação Nacional de Pesquisa em Pós-Graduação em Ciências Sociais - ANPOCS -, criada em 1979, e a revista Espaço e Debates, publicação que cumpriu um papel análogo ao de EURE, no Chile, na consolidação do debate sobre os MSUs (KOWARICK, 1987). Normalmente, as revistas acadêmicas cumprem um papel fundamental na conformação de uma identidade intelectual coletiva, permitindo a definição de posições e a difusão de ideias renovadoras. A projeção de determinados grupos intelectuais não seria possível sem a existência, entre outros elementos, de um veículo editorial que delimite o perfil intelectual destes coletivos (PONTES, 1998).

Tal polêmica significou uma oscilação nas interpretações entre a ênfase no caráter político dos pobres urbanos, enquanto agentes de transformação, e a explicitação das limitações políticas de sua ação coletiva (JACOBI, 1987). Portanto, não se pode ensaiar uma tentativa de reconstrução da produção teórica carioca sobre o movimento favelado sem levar em consideração a produção científica que paralelamente se elaborou em São Paulo. Agora, não se deve compreender esta polarização em torno ao eixo Rio-São Paulo como o posicionamento de escolas de pensamento homogeneamente rivais. A influência de Manuel Castells também marcou presença no Rio de Janeiro (LIMA, 1989), e uma das mais completas e demolidoras críticas ao que Machado e Ribeiro (1985) entenderam como o Paradigma dos MSUs foi elaborada em São Paulo por Ruth Cardoso (1987). Embora a ideia de que existiu uma polarização possa nos levar a perder algumas das nuan- 
ces desta polêmica, o estabelecimento de uma espécie de trincheiras de pesquisadores sediados em centros ligados principalmente à USP e ao IUPERJ não deixa de ser útil descritivamente, apesar do risco de simplificação implícito no exercício.

A primeira parte deste capítulo tratará do processo de demarginalização da questão urbana no Rio de Janeiro, ou seja, a desconstrução crítica dos principais pressupostos da teoria da marginalidade, que, como visto, foi a principal tendência explicativa do fenômeno urbano no mundo acadêmico que estudava os processos de urbanização nos países em desenvolvimento durante os anos 1960. Essa desmitificação será chave, porque nela se delinearam os principais traços da leitura utilitarista elaborada no Rio de Janeiro como alternativa à leitura dos MSUs. Posteriormente, como contraponto à perspectiva elaborada no Rio de Janeiro, mapear-se-á a conformação do Paradigma dos MSUs proposto pelos pesquisadores paulistas, receptores e intérpretes originais do legado teórico de Manuel Castells, inicialmente descrevendo a interpretação do processo de urbanização e marginalização realizado em São Paulo nos anos 1970. Se, nos anos 1970, a ênfase estava na economia ou na infraestrutura, nos anos 1980 estará na política ou na superestrutura do sistema. Finalmente, o capítulo será encerrado com os principais elementos da perspectiva anti-MSU proposta no Rio de Janeiro.

\section{A desmarginalização da questão urbana no Rio de Janeiro}

A partir da segunda metade da década de 1960, as críticas à Teoria da Marginalidade foram se generalizando cada vez mais. No Rio de Janeiro, os principais estudiosos da questão social urbana tinham se dedicado cedo à tarefa de questionar os seus supostos. Porém, se existe um divisor de águas nessa trajetória, será a publicação de um número especial, em 1969, da Revista América Latina do Centro Americano de Pesquisas em Ciências Sociais, dedicado às favelas. Embora a ruptura nesse número não fosse total - na própria 
apresentação do Dossiê Manuel Diégues Júnior assumirá a existência de uma subcultura da pobreza nas favelas cariocas -, nele ficaram bem esboçados os principais traços da crítica, principalmente desenvolvida no Rio de Janeiro, à Teoria da Marginalidade, além de, numa mesma publicação, estar reunida boa parte dos principais nomes do campo de estudos das favelas cariocas.

Estes autores coincidiram em mostrar a favela como um produto da urbanização carioca e, portanto, como parte da cidade, de modo que a ideia da favela enquanto problema dará passo a uma interpretação que a concebe conforme uma solução popular ao desafio da vida na metrópole, como uma fonte de solidariedade, onde as normas não estão ausentes, até nos espaços mais associados à marginalidade, como os lugares de consumo de álcool.

Lucien Parisse (1969, p. 7), por exemplo, afirmará que: “as favelas constituem um dos procesos de expansão do Rio de Janeiro e participam da organização e do dinamismo do espaço urbano”. As favelas não são um corpo anômalo na cidade, mas o resultado das funções da metrópole, e satisfazem parte significativa da demanda por habitação produzida pela explosão populacional provocada no Rio de Janeiro tanto pelo crescimento vegetativo como pela chegada de migrantes. $\mathrm{O}$ crescimento das favelas responde à própria dinâmica urbana, sendo, desde as décadas de 1940 e 1950, parte integrante do fenômeno urbano. Antes disso, e desde finais do século XIX, a favela existiu, mas como uma forma de habitação pobre entre outras; porém, a partir de 1940, a favela conquista a atenção pública, principalmente pela gestão do prefeito Henrique Dodsworth, quem buscou, via construção de "Parques Proletários" (BURGOS, 2004), a eliminação e moralização das populações faveladas, e pelo que se conheceu como "Batalha do Rio" (1948), na qual o jornalista e político conservador Carlos Lacerda (1987) lançará uma série de apelos sobre a "questão das favelas" e a necessidade de sua superação/eliminação. 
Parisse (1969, p. 16) mostra, mediante dados dos censos, como a localização das favelas se relaciona com o grau de urbanização da cidade. Assim, quanto maior a densidade populacional ou a comunicação com o centro da cidade, maior o estímulo para o crescimento de favelas; e, com a presença de indústrias, a proximidade a postos de trabalho compensaria a localização em zonas da cidade menos urbanizadas. Desse modo, "os favelados habitam a área urbana já densamente povoada e integrada na parte mais velha da cidade, onde se encontram um mercado de trabalho e uma rede desenvolvida de transportes intra-urbanos, escolas e hospitais acessível aos pobres". Portanto, a favela não pode ser concebida como um acidente ou uma anomalia, pois existiria uma relação entre a aparição das favelas e a evolução da própria cidade que as alberga (aumento da população e ocupação do espaço). Ao mesmo tempo, a falta de um Plano Diretor da cidade e o forte papel da iniciativa privada e da especulação imobiliária favoreceriam a difusão das favelas na trama urbana. "A favela se inscreve neste contexto de crescimento não organizado. Embora permaneça à margem da especulação imobiliária e da urbanização legal, a favela não escapa à exploração financeira dos 'donos' do terreno ou dos barracos. A busca de lucro condiciona também o desenvolvimento das favelas" (PARISSE, 1969, p. 26). A favela é um componente da urbanização carioca: possui uma função residencial indispensável para a população pobre da cidade; possui uma função laboral, pois nas favelas se concentra uma parcela importante de mão de obra disponível para o mercado de trabalho e, ao mesmo tempo, é um mercado de consumo importante; possui uma função política que, embora subordinada e exposta à manipulação, corresponde a um meio de integração à vida urbana; e, finalmente, possui uma função cultural, uma vez que expressões como o samba e o carnaval encontraram na favela um terreno fértil para seu desenvolvimento como expressões culturais próprias do imaginário do brasileiro. 
A favela constitui um processo de expansão urbana. Ao começar a atual fase de urbanização, a favela carioca se afirmou como uma forma de habitação pobre para uma população sempre crescente. A favela está presente em setores privilegiados, em relação com o aumento de densidade populacional e a integração do bairro na cidade. As favelas se inscrevem na paisagem do Rio de Janeiro, refletem na sua fisonomia as condições e circunstâncias de sua implantação, manifestam os fatores regionais e nacionais que a determinaram. Finalmente, a favela tem se transformado num dos maiores problemas do desenvolvimento planejado e integrado da aglomeração carioca (PARISSE, 1969, p. 42).

Em outra chave interpretativa, mas que nem por isso deixa de mostrar muitas coincidências, Anthony Leeds (1969) mostrará que a origem rural recente dos moradores de favelas não é verdade, assim como não existe um tipo de personalidade específica dada pela condição de ser residentes de favelas, pois os favelados não seriam diferentes de outras porções da classe operária ou de outras populações da cidade. Dessa maneira, ele será enfático ao afirmar que boa parte da literatura especializada generalizou uma série de características como próprias das favelas, ignorando - deliberadamente em muitos casos - não apenas que essas características estão presentes em outras áreas da cidade, como também a existência de uma ampla variedade de formas de habitação popular precárias, das quais as favelas são um exemplo. Os squatments possuem enormes variações de formas, características e estado de desenvolvimento em toda a América Latina e, tal como mostra nas suas pesquisas, empiricamente os moradores de favelas não são idênticos ao que os teóricos da marginalidade identificam como populações “marginalizadas". Ao mesmo tempo, coincidirá com Parisse ao compreender as favelas como um produto da operação de sistemas capitalistas caracterizados por sistemas urbanos em transformação desde economias mercantis a economias industriais generalizadas. 
Seguindo esta tendência de acentuar a funcionalidade social da favela, Casasco (1969) destacará vários elementos positivos que os slums oferecem a seus habitantes. A definição do slum como uma área decadente física e socioeconomicamente, associada à pobreza, a ingressos de subsistência e patologias sociais é, pelo menos, parcial e incompleta. Embora uma favela possa albergar atitudes coincidentes com o que se conheceu como "cultura da pobreza" (Slum of Despair), também pode ser considerada como o ponto de partida de uma trajetória de superação econômica e de integração social (Slum of Hope). De uma maneira similar, numa pesquisa posterior, Schüly (1981) mostrará que, embora do ponto de vista de suas características existam populações factíveis de ser consideradas como marginais, do ponto de vista psicossocial podem ser consideradas como integradas, sobretudo pela autopercepção que estas populações cultivam em relação a seus parâmetros de referência familiares e ao seu próprio passado recente. A favela é, nestes casos principalmente, uma alternativa real e acessível para satisfazer a necessidade de habitação dos pobres urbanos, e, mesmo sendo inadequada, permite diminuir o déficit de habitação e oferece a oportunidade de absorção de uma parcela importante da população na sociedade urbana. Assim, a favela e seus equivalentes funcionais oferecem um primeiro ponto de apoio, mesmo que precário, para os recém-chegados à cidade e para uma eventual transição a outra posição social; também, normalmente, oferece uma geografia de oportunidades de trabalho pela sua localização próxima de setores de maiores ingressos em atividades não qualificadas ou semiqualificadas. As favelas não são uma simples patologia urbana nem unicamente um lugar no qual convergem pobreza, crime e desesperança.

Por sua vez, Carlos Alberto Medina (1969) criticará a exotização da favela carioca, ou seja, sua transformação num objeto isolado do resto da sociedade e, portanto, convertido num microcosmos. O exotismo da favela teria sido estimulado em boa me- 
dida por uma série de americanistas interessados nos problemas do "subdesenvolvimento". A tendência a estudá-la isoladamente e como algo exótico, sem considerar o contexto global no qual se enquadra a realidade da favela, leva a que a atribuição de determinadas características tanto ao espaço como aos seus habitantes termine por se converter numa profecia que se cumpre por si própria:

Assim, a visão do exótico e do 'problemático' se apresenta setorial e qualitativamente demarcada, funcionando como uma cobertura, quando não uma fuga, para a efetivação de uma atitude profissional científica, encobrindo suas deficiências, valorizadas pelo aspecto jornalístico de uma descrição exótica, ou da 'coragem' de mostrar uma situação considerada 'problemática'. Setorializando, aqueles profissionais impedem que se veja a população residente nessas áreas de estudo como gente, em muitos aspectos bem semelhante a outros grupos populacionais, todos participantes da dinâmica toda do processo, isto é, como membros do sistema social global vigente (MEDINA, 1969, p. 114).

A favela não pode ser compreendida como dotada de um caráter específico. Para o autor, não existe, por exemplo, uma "Política na Favela”, daí sua crítica a Machado (1967). A delimitação de um espaço favelado é produto da imposição de limites sociais "de fora" da favela. Setores da sociedade vinculam uma determinada área com determinadas características sociais, outorgando a este espaço a condição de um todo homogêneo e impenetrável, o qual não deve se misturar com o resto da cidade. Seria a proximidade da favela o que exigiria a delimitação social; logo, no subúrbio, a ideia de favela tende a desaparecer. Porém, Medina (1969, p. 118) admite um elemento diferenciador na favela:

Há um aspecto do 'exotismo' na favela que precisamos ressaltar e que torna claro sua situação diferencial de fato. Não um exotismo 
em si, mas a permanência na cidade de condições de vida próprias do meio rural. Este aspecto já foi mencionado em trabalhos anteriores, dando à favela uma característica de permanência do mundo rural, em que muitos comportamentos e atitudes da sua população são mantidos justamente devido ao seu isolamento geográfico e servem como um meio ambiente defensivo ao impacto com o mundo técnico da cidade. É esta permanência de traços rurais que pode diferenciá-la do resto da cidade e fazer sentir no seu visitante citadino a sensação de estar penetrando num mundo ambiente distinto.

Embora a favela já não seja vista como um quisto rural, aparece como um espaço depositário de uma cultura rural que pode até fazer crer erroneamente aos pesquisadores que estão frente a uma realidade diferenciada. Mesmo possuindo uma cultura com bases rurais, a favela não perde a vinculação com a sociedade na qual se insere.

Por outra parte, se a sociedade precisa segmentar e se diferenciar das favelas, os favelados se veem estimulados a gerar um processo de diferenciação social interna para se apresentarem frente à sociedade como dotados de características que permitirão sua melhor inserção na vida social. A favela, portanto, não é uma realidade homogênea, mas um mundo fragmentado e dividido. Os moradores de favelas encontram diversos mecanismos para sobressaírem e se diferenciarem do resto da vizinhança, sendo a vinculação com algum agente externo, mediante algum tipo de atividade social, a forma mais destacada por Medina. Embora habitem uma área homogênea geograficamente, nas favelas convivem uma imensa quantidade de organizações com interesses e alcances diversos sem vinculação necessária entre eles, e cada uma com seu próprio dirigente. Não existe uma estrutura interna que vincule a população dentro das favelas, o que existe são pessoas que moram numa mesma área, mas buscando sua identificação com o mundo 
"de fora", se diferenciando com os "de dentro". Sendo as diversas organizações em seu interior um excelente meio de vinculação com o exterior toda vez que, em geral, essas organizações sejam produto do estímulo de um agente externo (por exemplo, Igreja Católica). A condição de liderança de alguma organização social representa uma fonte disponível de prestígio social e de conexão com o exterior. A instrumentalização dos vínculos externos e das organizações sociais para a conquista de status tem como consequência a inibição ou limitação da ação coletiva.

O que procuramos mostrar aqui é que a tônica desta população é sua dependência às forças externas, exógenas, únicas capazes de permitir a seus moradores saírem de suas posições atuais. Que esta tônica se expressa no plano concreto por uma busca de diferenciação de alguns moradores dos demais, apoiados na iniciativa daqueles que se julgam de nível mais alto e que as atividades realizadas no local servem para, diferenciando-os, dar-lhes o prestígio necessário à elevação de seu status social. Em nenhum momento, a finalidade dessas atividades adquire um sentido construtivo e comum, pelo contrário, servem apenas para criar cargos a serem ocupados e, isto feito, serem mantidos pelos que os ocuparem. A visão inadequada dessa realidade vai se expressar na impossibilidade de ações coletivas indispensáveis para a solução de muitos problemas comuns existentes. A estrutura atomística descrita, com seus elementos de diferenciação e de prestígio, impedirá, se não houver alterações deles, qualquer iniciativa que se apoie e se sustente na ação coletiva e voltada para o bem comum. Esta pressupõe identidade de direitos e deveres, impossíveis de serem aceitos por justamente identificarem pessoas cujo valor maior é tornar-se diferente (MEDINA, 1969, p. 133).

Se, na sua anterior leitura, Medina (1964) via na favela uma erva daninha que poluía o tecido urbano, uma extensão rural na 
cidade que se expressava numa cultura cabocla que fazia dos favelados uma massa de manobra disponível para os demagogos, e, portanto, incapazes de uma ação coletiva organizada; nesta versão, a favela manterá seus traços rurais, mas será a busca de integração na cidade a que levará os favelados a instrumentalizarem as organizações sociais em busca de diferenciação social e status. Embora aqui os favelados não apareçam como os manipulados, pois são eles os que manipulam as organizações locais e os vínculos externos que estas oferecem, a leitura de Medina mantém como fio de continuidade a incapacidade de mobilização coletiva. A orientação a fins individuais das lideranças na busca de prestígio condenaria a favela e suas organizações ao atomismo e ao fracionamento paralisante.

Por outra parte, Jean Pierre Bombart (1969), no seu estudo sobre os cultos protestantes na favela Jacarezinho, mostrará uma imagem totalmente diferente da favela da que foi difundida pela Teoria da Marginalidade. Ao contrário da ideia de um lugar alheio a qualquer norma social, onde primam valores negativos que impedem a integração destes setores à sociedade moderna, nos diferentes cultos estudados existia uma série de signos de distinção dados por normas estritas de comportamento e autocontrole: “o protestante se valoriza aos seus próprios olhos graças ao prestígio do grupo ao qual pertence. Cada grupo tende assim a se diferenciar dos outros conforme a suas normas e valores. As seitas põem o acento sobre a prática da ascese enquanto as igrejas insistem sobre a honestidade, a coragem, e a boa educação, enquanto qualidades que levam ao sucesso social”. (BOMBART, 1969, p. 155). Para ele, esse comportamento não é um fato isolado, já que o sistema de cultos protestantes não pode ser separado da evolução da própria favela na adaptação à moderna sociedade industrial, onde o processo de racionalização do comportamento e a interiorização de normas são eficientes mecanismos de integração a ela. As próprias seitas protestantes são vistas como uma resposta à necessidade de integração, segurança e promoção social dos favelados. 
O texto de Machado (1969), O significado do botequim, não deixa de ser provocador, uma vez que propôs mostrar o papel do botequim na vida social daqueles considerados "marginalizados", etnografando dois botequins frequentados por moradores de favelas e mostrando sua importância na sociabilidade desta parcela da população. Ao contrário do que se poderia esperar a partir da Teoria da Marginalidade, um espaço destinado ao consumo de bebidas alcoólicas não apareceu como um universo anômico e antissocial. Apesar do caráter informal das relações sociais desenvolvidas no seu interior, estas tendiam a ser muito estáveis, com um alto grau de rotinização, o que propiciava a formação de grupos e subgrupos claramente delimitados. O botequim não apenas seria uma forma de inserção no meio urbano, por estar relacionado com o sistema de consumo, como também permitiria a aparição de um "sentimento de comunidade". Assim, o botequim seria uma espécie de refúgio para os trabalhadores urbanos em busca de um espaço de identificação e resguardo frente às pressões da sociedade moderna, permitindo formar uma ótica que contribui para dar sentido àquele mundo. "O freguês sente-se integrado e participante de um todo mais amplo, enquanto parte de um microcosmo que é, ao mesmo tempo, uma defesa contra o macrocosmo 'desconhecido' e 'incompreensivel" (SILVA, 1969, p. 180). O botequim oferece a recuperação de um sentimento perdido de comunidade na moderna metrópole, permitindo estabelecer estreitas relações de cooperação e marcos de resolução de conflitos de forma mais amena.

Paul Silberstein (1969) também propôs uma leitura alternativa à da cultura da pobreza que identificava na desorganização interna uma âncora que mantinha os favelados nessa cultura. Para ele, o baixo nível de participação nas organizaçóes sociais e nas associações formais respondia a uma sofisticada adaptação dos pobres aos estreitos limites e limitações impostas pela pobreza. Antes de uma manifestação de marginalidade, o que está em jogo é uma hábil gestão das relações sociais, onde os moradores de favela cul- 
tivam uma série de relações diádicas em diferentes direções, orientadas à obtenção de recursos materiais e emocionais. Diariamente os favelados mobilizavam contatos locais, jogavam em diversas direções, rompiam compromissos quando necessário, controlando e manipulando estes vínculos sociais. Embora isto possa gerar conflitos e dilemas morais nos favelados, este fenômeno mostrava que eles não estavam socialmente isolados e que apresentavam grande habilidade para administrar os limitados recursos sociais dos quais dispunham para se adaptar a um meio, a maior parte do tempo, totalmente adverso.

Em geral, com variadas ênfases, os autores deste número especial de América Latina mostraram que os favelados desenvolvem uma série de estratégias de adaptação, sobrevivência e eventualmente superação de sua condição de pobreza. A própria favela deixa de ser uma condenação e uma perpetuadora da mesma para virar uma manifestação a mais dessas estratégias. A favela deixa de ser um foco de perdição moral, onde qualquer forma de solidariedade está ausente. Nela, os favelados não apenas geram contatos extrafamiliares como os administram em função da obtenção de recursos (materiais ou simbólicos), participam de organizações para obter status social, criam refúgios frente à ameaçante vida na metrópole, integrando-se com maior ou menor sucesso a ela. Porém, chama atenção a ausência de uma leitura que considere o potencial de ação coletiva dos favelados. Este será um traço bastante marcado da bibliografia que no Rio de Janeiro estudará o fenômeno da favela.

Este número, além do mais, estava totalmente em sintonia com os questionamentos que ao final dos anos 1960 se dirigiam contra a marginalidade, realizados principalmente por pesquisadores estadunidenses que estudavam a urbanização no terceiro mundo. Isso não surpreende, uma vez que, no número, participaram autores como Antonhy Leeds, um dos principais nomes deste processo de revisão, assim como outros cientistas americanos, 
e que o Rio de Janeiro foi um dos lugares que mais concentrou esforços de pesquisa neste tópico. Rio de Janeiro sempre foi uma cidade densa de pesquisadores do urbano. Não é de estranhar, então, que se reunisse uma quantidade de material empírico sobre a cidade suficientemente amplo e consistente para desacreditar boa parte dos pressupostos da teoria de marginalidade.

Dois autores exemplares desta onda de questionamento foram William Mangin e John Turner. Ambos deixaram de ver nas favelas um problema e enfatizaram seu caráter de solução. Para Mangin (1967), a formação de favelas ou equivalentes é uma resposta popular ao acelerado processo de urbanização experimentado por países incapazes de satisfazer as demandas provocadas pelo incremento da população urbana. As favelas são um processo de construção social de iniciativa popular e representam, ao invés de um problema, uma solução aos seus problemas. Esta iniciativa popular significou que milhões de pessoas no mundo resolveram seu problema de habitação em países onde nem o Estado nem o mercado eram capazes de oferecer uma alternativa. Ao mesmo tempo, a criação de favelas permitiu a consolidação de um mercado de trabalho determinante para a evolução econômica e urbana dessas cidades. Outra contribuição é o crescimento de um mercado de consumo que, embora pequeno nas suas unidades (pequenos negócios e empresas), significou uma circulação monetária sumamente importante para a vida da cidade. Por outra parte, a formação de favelas criava comunidades e formas populares de capital social. Estas contribuições serão poderosos antecedentes para questionar o "mito" da marginalidade. Assim, para Mangin, embora nas favelas seja possível achar elementos de uma cultura rural, estas são o resultado de um fenômeno urbano, produto de decisões de residentes urbanos de larga data. A organização política não é a consequência de padrões rurais de comportamento, mas um fenômeno novo. Porém, a existência de organizações internas não confirma a existência de uma inclinação dos favelados à radicalidade: 
Minha própria impressão, a partir dos estudos citados e de minha experiência em Lima, é que uma ideologia paternalista, combinada com um slogan de 'não os deixem tomá-la', poderia ser mais apelativo que uma abordagem revolucionária do tipo 'vamos rebelar-nos e matar a oligarquia'. Provavelmente não muitos habitantes dos assentamentos irregulares lamentariam se alguém levasse a cabo a última ação, mas eles mesmos estão muito ocupados. Das muitas instâncias de confrontos reportadas, e em geral subsequente violência por parte da polícia durante invasões e tentativas de desalojamento de terrenos, apenas uma parece ter envolvido organizações de partidos políticos radicais. Esse caso parece fazer referência a comunistas locais, não ideológicos (MANGIN, 1967, p. 83).

Em uma linha similar, John Turner (1968) argumentará que a aparição das favelas é uma manifestação normal do processo de crescimento urbano sob condições históricas inéditas. $\mathrm{O}$ problema não é a favela em si própria, mas seu crescimento descontrolado e as formas excessivamente precárias que às vezes toma. As favelas não são uma aberração social, mas uma resposta bastante adequada frente a uma situação específica. As favelas e seus equivalentes são, nesse contexto, inevitáveis, mas o que pode resultar trágico é que muitas sejam piores do que precisam ser. A habitação precária é resultado do processo de modernização, e não um sintoma de sua ausência. Porém, muitas vezes o fato de serem assumidas como um lugar provisional de habitação desestimula o investimento em melhoramentos. Embora isso possa deteriorar a qualidade de vida de seus moradores, termina por ser a solução mais racional para quem tem poucos ingressos ou está desempregado. Assim, apesar de para o poder público ou para os urbanistas as favelas possam ser um problema imediato a ser resolvido, para seus moradores é basicamente uma solução. A existência desta forma de habitação 
é produto da diferença entre a demanda popular por moradia e a demanda/oferta institucional da sociedade.

Do ponto de vista político, a contribuição que considero mais original para questionar os pressupostos da teoria da marginalidade será a do já citado Anthony Leeds (1978). Nas suas pesquisas sobre o Brasil urbano, esse autor, junto com Elizabeth Leeds, desenvolverá uma definição da "política" que será fundamental para a consolidação do debate no campo brasileiro. Política será "qualquer ação, articulação de interesses ou tentativa feita por um ator para manobrar órgãos públicos e privados que têm como objetivo a extração de bens e serviços de um dado sistema por outros meios que não as trocas padronizadas de valor, em geral dinheiro" (LEEDS e LEEDS, 1978, p. 266). Nesta visão, a utilização de canais paternalistas e individualistas para obter favores e satisfação de interesses através de troca de benefícios (apoio político em troca de serviços urbanos, por exemplo), provocada pela falta de resposta dos responsáveis governamentais, é compreendida como política. Apesar da restringida definição de política, esta visão o levará a concluir que, ao contrário da literatura de sua época, a relação entre uma população proletária determinada com a comunidade política externa não é necessariamente uma relação de exploração unilateral por parte destes últimos. Daí sua valoração dos favelados como "animais políticos":

Muitos dos moradores da favela não apenas estão interessados, mas valorizam a real participação em problemas políticos de todo tipo. Justamente com os políticos profissionais e administradores da política brasileira, os moradores da favela são os mais sutis e políticos que já encontramos, muito mais políticos em todos os sentidos, do que a população americana como um todo, e dificilmente comparáveis a quaisquer categorias de pessoas equivalentes nela. A política é um jogo, uma recreação, um sistema de recompensas, um gozo do poder, uma estrada para a mobilidade 
econômica, um caminho para a mobilidade social e um compromisso com alguns conjuntos de interesses. O jogo da política é extremamente complexo, movendo-se em muitos níveis, por múltiplos modos de expressão, por múltiplos caminhos de relação interpessoal (LEEDS e LEEDS, 1978, p. 122).

Sem dúvida, influenciado pela concepção de política de Leeds, Machado (1967) desenvolverá umas das reflexões mais sugestivas sobre a política na favela. Em um artigo intitulado A Politica na Favela, ele destacará o fato de a favela apresentar um grau de especificidade distintivo, dado por formas de organização (sociais e econômicas) aparentemente exclusivas, mas sem constituir um sistema autônomo, autossuficiente e independente. Traço particular da política nestes lugares será a existência de uma "burguesia favelada" - revelando que não existe um tipo único de favelado - a qual monopolizaria o acesso e o controle dos recursos econômicos e sociais (contatos políticos). A capacidade de intermediação da "burguesia favelada" posicioná-la-ia em um lugar privilegiado para ter acesso a recursos externos, oferecendo em troca um potencial apoio interno. Seu poder estaria dado, então, pela potência eleitoral (supervalorizada) da favela. Nessa lógica, os outros favelados, notadamente os de estratos mais baixos, aparecem como "massa de manobra" explorada pela "burguesia favelada" através de vínculos pessoais. Nesta situação vantajosa, a "burguesia favelada” se orienta a uma ação política de curto prazo e imediatista, pois, não obstante esteja ciente de suas limitações para influir eficazmente no nível estrutural, sabe que de pequenos acordos políticos pode obter benefícios (muitas vezes pessoais). Em contraste, os favelados de estratos mais baixos estariam condenados a uma posição subordinada, mesmo internamente, não apresentando a menor consciência política, a qual se reduz a meras revoltas difusas e a uma posição de "passividade defensiva". Exemplos disto seriam: 
a baixa percentagem de sócios das Associações de Moradores e a diferença entre eleitorado potencial e real nas eleições de diretoria. Em concordância com os autores mencionados, a favela não é uma comunidade isolada, como defende a Teoria da Marginalidade. Para Machado, a noção de "comunidade marginal" é mais o produto de um julgamento de valor e de uma atitude paternalista e assistencialista que uma visão realista deste espaço. A favela também não é um grupo dentro de um estrato social, como sugere o conceito de lumpemproletariado, pois nela impera uma enorme diversidade social, não existe um tipo único de favelado. Mas, neste espaço, se desenvolvem dinâmicas próprias, e a política é uma delas. Embora Machado não acredite que os traços da política na favela sejam exclusivos, defenderá que é possível identificar empiricamente atitudes e comportamentos nos favelados, os que provavelmente estão condicionados, em parte, pela forma de organização da favela. Ela é um microcosmo, mas que não é independente de macrocosmo social.

Os políticos da favela mostram consciência de que os problemas dela estão além de ser uma mera questão habitacional, sabendo que sua capacidade para incidir politicamente no nível estrutural da sociedade é limitada. Porém, também percebem que determinados acordos políticos trazem benefícios alcançáveis, embora pequenos e às vezes apenas pessoais. Dessa maneira, a ação política tende a ter uma orientação de curto prazo e imediatista. Os políticos da favela praticariam uma política extremamente realista e perspicaz, longe da imagem de inocência e passividade atribuída pelas teorias marginalizantes. Para retratar este ponto, Machado utilizará uma fala de um favelado sobre um chamado que recebeu do diretor de uma agência que agia na favela: "O diretor disse que queria me avisar que eu estava sendo usado pelo deputado... Eu respondi que não, que eu é que estava usando o deputado. Só que eu não disse que quem estava sendo usado pelo deputado era o diretor". 
Falar de "burguesia favelada" é provocador, mas não clarificador. Sendo praticamente um negativo da "aristocracia operária", provoca, porque utilizar uma categoria desprezada pela esquerda como "burguesia" e associá-la a uma figura idealizada pelos intelectuais radicais (os favelados) é, pelo menos, contraintuitivo. Porém, ao mesmo tempo, pode confundir na medida em que transmite a falsa ideia de que na favela se replica a divisão de classes e eventualmente uma luta entre a burguesia favelada e algum grupo equivalente ao proletariado. Um comerciante dentro da favela ou liderança que monopoliza o acesso à água pode ser considerado um "burguês", mesmo tendo um nível de ingresso maior que seus vizinhos? Embora me incline a responder negativamente a esta pergunta, a categoria permite mostrar que no interior da favela existe variedade, que ela não é um todo homogêneo, e que dentro dela podem se criar relações de dominação entre os próprios favelados.

Finalmente, Janice Perlman (1977) consagrará uma das críticas mais conhecidas à marginalidade. Buscando se contrapor ao "constante empenho dos poderosos por culpar os pobres por sua situação", a autora mobilizará uma enorme quantidade de material empírico, principalmente de caráter etnográfico, para desmitificar a marginalidade em cada uma de suas dimensóes: social (desorganização interna e isolamento interno), cultural (tradicionalismo e cultura da pobreza), econômica (parasitismo econômico e paroquialismo econômico) e política (apatia política e radicalismo político).

Pelo protagonismo que tem a política neste texto, nos concentraremos na última dimensão analisada pela autora. Contrária à noção de apatia política que supostamente caracterizaria os favelados, ela mostrará a existência de um sistema político interno, onde os favelados participariam ativamente das organizações locais e procurariam estabelecer vínculos com a sociedade exterior. Destaca também a existência de lideranças com uma aguda percepção do funcionamento político externo, o que permitiria 
uma eficiente seletividade para se concentrar em interesses locais e assim obter resultados. Não sem realismo, ela afirma: "a questão é que, nas condições vigentes em 1968-69, eles não estavam dispostos a assumir riscos extremos ou a acalentar ilusões ideológicas" (PERLMAN, 1977, p. 228), contrariando aqueles que esperavam um levantamento popular que mudasse o curso dos acontecimentos, após o golpe de Estado no Brasil. Nesse sentido, a conclusão é clara: não se pode compreender a política na favela sem considerar o contexto de repressão política próprio de um regime ditatorial, que nela se especificava de diversas maneiras. Sua crítica à marginalidade, por ter sido escrita já na década de 1970, mostra uma sintonia com a visão que se consolidou no Rio de Janeiro por oposição às interpretações ligadas à escola dos MSUs, que encontrou em São Paulo destacados intérpretes.

\section{Marginalidade e Exército de Reserva: a leitura paulista da urbanização}

A recepção da teoria da marginalidade em São Paulo será diferente à do Rio de Janeiro nos anos 1970. Os pesquisadores de São Paulo tentaram compreender o processo de urbanização, reconhecendo a existência do fenômeno da marginalidade, mas rejeitando a noção de "polo marginal” ou "massa marginal”. Nesse sentido, o debate será antes contra Aníbal Quijano do que com a versão culturalista da marginalidade. $\mathrm{O}$ exercício de crítica à marginalidade cultural, defendido pelo DESAL, no Chile, parece não ser necessário para estes autores, por considerarem que já está presente na sua crítica à "razão dual” (OLIVEIRA, 1972) e no quadro geral da teoria da dependência (CARDOSO e FALETTO, 2003). Aliás, às vezes a própria categoria de "cultura da pobreza" parece ser assumida como um fato dado nas condições de urbanização brasileira. Assim, por exemplo, em 1971, um grupo de pesquisadores (CARDOSO et al., 1971), ao analisar a cultura e participa- 
ção urbana em São Paulo, mesmo reconhecendo que a noção de uma cultura rural transplantada no meio urbano pelos migrantes marginalizados não tem respaldo, não estabeleceram uma ruptura com as premissas da marginalidade e da cultura da pobreza. Pelo contrário, elas aparecem como supostos de parte da análise: o desajuste da cultura dos migrantes na cidade e um estilo de vida que resulta de níveis econômicos precários e padrões de comportamento social deficientes para enfrentar os desafios da cidade. A incapacidade do poder público para dirigir o desenvolvimento urbano da metrópole paulista se explica pela força e dinamismo do setor privado e pela ausência política dos setores populares, que em muitos casos aparecem como instrumentalizados pelos próprios interesses privados através das Sociedades de Amigos de Bairro. O morador de São Paulo ainda estaria longe de virar um verdadeiro cidadão ou de guiar o desenvolvimento da cidade de acordo a interesses mais gerais.

A marginalidade para estes pesquisadores é antes uma questão ligada ao mercado de trabalho que uma questão especificamente urbana. $\mathrm{O}$ viés econômico é tão forte e o descuido com o cultural é tal, que até a noção de cultura da pobreza sobrevive nestes estudos. Em boa medida, a concepção paulista sobre marginalidade é uma atualização da polêmica realizada entre José Nun (2001) e Fernando Henrique Cardoso na Revista Lationamericana de Sociologia, onde este último defenderá a pertinência do conceito marxista de Exército de Reserva para dar conta da existência de parcelas da classe operária marginalizadas na urbanização. Se, para Quijano e Nun, a marginalidade é inerente ao capitalismo, mas afuncional, para o grupo de São Paulo a marginalidade é funcional a seu desenvolvimento. $\mathrm{Ou}$ seja, inicialmente não rompe com o conceito de marginalidade, pois

Não se quer dizer que não haja marginalidade social nas cidades, mas essa marginalidade social é, ela mesma, um componente dos 
exércitos industriais de reserva. Não significa, tal como a teorização da marginalidade social tenta dizer, exclusão do mercado de trabalho, nem exclusão da economia urbana. Significa a forma peculiar pela qual a industrialização brasileira trouxe para dentro de si, de uma só vez, de uma pancada, todo esse exército-industrial de reserva, vindo dos campos para dentro das cidades (OLIVEIRA, 1982, pp. 42-3).

Em uma recopilação de artigos originalmente publicada em 1973, Paul Singer (1978, p. 28) elaborará uma teoria da urbanização, de raiz marxista, na qual o desenvolvimento do capitalismo se confunde com o processo de urbanização. Pensar numa revolução urbana é aqui análogo a pensar na revolução industrial.

A problemática urbana só pode ser analisada como parte de um processo mais amplo de mudança estrutural, que afeta tanto cidade como campo, e não se esgota em seus aspectos ecológicos e demográficos. Na verdade, hoje mais do que no passado, estes aspectos não passam de uma primeira aparência de um processo mais profundo de transformação da estrutura de classes e dos modos de produção em presença. É por isso que a análise do processo de urbanização não passa, muitas vezes, de uma abordagem inicial que é obrigada a superar o seu próprio tema se, de fato, deseja elucidá-lo. Portanto, quando se pensa em urbanização numa sociedade que se industrializa, é preciso procurar pelo papel que as classes sociais desempenham nela, pois, em caso contrário, ela tende a ser tomada como um processo autônomo, fruto de mudança de atitudes e valores da população rural, perdendo-se de vista seu significado essencial para o conjunto da sociedade.

Para Singer, é inadmissível que uma parte da força de trabalho não seja aproveitada pelo sistema, para o que apoiará sua tese no clássico conceito marxista de Exército de Reserva. $\mathrm{O}$ capitalis- 
mo precisa dele para seus momentos de expansão e para controlar eventualmente a pressão por maiores salários. $\mathrm{O}$ "sustento" deste exército nos países desenvolvidos normalmente se realiza mediante seguros de desemprego e políticas de bem-estar social; porém, nos países em desenvolvimento, este toma a forma de uma transferência individual, mediante a compra de serviços de trabalhadores autônomos, o que explicaria a hipertrofia do setor informal da economia brasileira (tercerização): empregadas domésticas, biscateiros, ambulantes etc.

Os baixíssimos níveis de consumo destas massas potencialmente disponíveis para expansão da economia explicam a existência de comunidades economicamente fechadas no meio urbano (favelas, villas miseria etc.), cuja economia se limita quase à subsistência, porém nas quais uma extensa rede de trocas de bens e serviços dentro da comunidade permite sua continuidade.

Estes argumentos visavam questionar a ideia de urbanização dependente de Quijano (ver capítulo 3), também recolhida por Castells (1973b), mas, sobretudo, o conceito tematizado é o de polo marginal. A existência de um polo hegemônico e outro marginal deixaria fora de análise um vasto número de posições que não entram nessa definição bipolar; além do mais, como já falado, Singer defenderá o poder explicativo do Exército de Reserva. Ele acusa estes autores de reproduzir a "crítica antiurbana", na qual o problema seria o excesso de urbanização da América Latina. e esta distorção, por sua vez, seria o produto da dependência. $\mathrm{O}$ problema da superconcentração urbana apontado por Quijano e Castells é secundário para Singer: a questão principal é a concentração do capital. Assim como o problema não são as migrações em si. No capitalismo, a liberação de força de trabalho que é obrigada a migrar é produto das mudanças nas relações de produção; a questão é que a mobilidade é insuficiente enquanto Exército de Reserva. Estas massas, por falta de informação e meios, muitas ve- 
zes se mobilizam a cidades que não foram escolhidas pelo capital para dirigir o processo de acumulação.

O desenvolvimento capitalista da economia brasileira foi profundamente marcado por esta ampla mobilização do exército industrial de reserva, que deu lugar a um abundante suprimento de força de trabalho pouco qualificada e não qualificada, limitado apenas pela legislação do trabalho, principalmente pelo salário mínimo. Isso explica o baixo grau de mecanização das atividades agrícolas e de construção civil e o relativo obsoletismo tecnológico dos ramos industriais mais antigos, como o têxtil e o de confecção de vestuário. A persistência de numerosas pequenas empresas artesanais e semiartesanais e do grande volume de força de trabalho e serviços domésticos também se explica pelo baixo custo da mão de obra (SINGER, 1978, p.123).

$\mathrm{Na}$ mesma linha, mas já se distanciando da ideia de marginalidade, a pesquisa de Manoel Berlinck (1975), um dos fundadores do CEBRAP - instituição que congregará pesquisadores chaves para o desenvolvimento da massa intelectual crítica que renovará o campo dos Movimentos Sociais Urbanos no Brasil -, será bastante ilustrativa para entender as nuances que adquirirá a interpretação da questão urbana em São Paulo. Berlinck estudará o problema da marginalidade social, mas na sua relação com a acumulação capitalista no Brasil. Este autor tentará demonstrar que não existe propriamente marginalidade social em São Paulo, mas sim pobreza engendrada e mantida pelo desenvolvimento econômico da região a partir do século XX. A industrialização paulista que acompanhou o crescimento urbano da metrópole gerou um excedente de mão de obra que foi fundamental para a acumulação de capital e indispensável para este desenvolvimento urbano-industrial. O crescimento econômico de São Paulo foi acompanhado de um persistente empobrecimento 
da mão de obra empregada na cidade, manifestado na deterioração das médias ocupacionais de migrantes e nativos e nas baixas expectativas a respeito das oportunidades sociais (educação, principalmente). A existência de mecanismos institucionais de espoliação que retiram do trabalhador parte de seus ganhos, e que acentuam sua presença na mão de obra não qualificada, assim como a própria existência de um exército de reserva disponível, permitiam a obtenção de um lucro marginal na indústria para setores que, de outra maneira, não conseguiriam operar no mercado. Rejeita com isso a tese da disfuncionalidade de um setor marginal da economia, pela importância deste setor para a acumulação. Ao mesmo tempo, Berlinck mostrará a ausência de uma cultura da pobreza, pois ele interpretará a utilização de mecanismos de interação baseados nas relações primárias de parentesco e amizade como um estoque simbólico comum às diversas camadas socioeconômicas presentes em São Paulo.

Similarmente, Maria Célia Paoli (1974) criticará tanto a versão culturalista como estruturalista da marginalidade, mas novamente o alvo principal dos questionamentos será Aníbal Quijano, pois sua preocupação estará muito mais no mercado de trabalho que na cidade. A marginalidade aparece aqui como uma forma acentuada de exploração, não como exclusão de uma fração do proletariado, mas como um tipo de força de trabalho superexplorado em função de uma modalidade específica de capital que opera de modo associado e desigual. Destaca-se, na preocupação da autora, a associação da marginalidade a novos focos dinâmicos dentro da estrutura dependente que possuem um potencial político de transformação do desenvolvimento em autores como Quijano. Mas, perguntar-se-á, "como explicar a aparente contradição entre a "inutilidade" econômica desta mão de obra enquanto produtora de valor e sua necessidade como presença histórica?” (PAOLI, 1974, p.27). O trabalhador dito marginal na verdade não é excluído nem sobrante em relação às necessidades de acumulação ca- 
pitalista, porém sua condição é marginal pelo baixo custo de sua reprodução como força de trabalho, ou seja, pela sua acentuada pauperização e exploração, as quais são formas de transferência de renda para os setores sociais mais acomodados; embora não exista um polo marginal, mas sim operam processos de marginalização de faixas do proletariado, nos quais se consolida uma forma de existência social com um nível de vida que não chega a cobrir os padróes minimamente aceitáveis para a sociedade brasileira.

Kowarick (1975) também se perguntará sobre o papel da marginalidade nas exigências de acumulação do capital e compreenderá os grupos marginais a partir de sua inserção na divisão social do trabalho. Seu objeto de estudo é, portanto, o exército industrial de reserva e o custo de reprodução da força de trabalho. A marginalidade é compreendida aqui como um modo de inserção nas estruturas de produção que faz parte significativa da dinâmica da acumulação capitalista, já que, num contexto de dependência, pode ser considerada como uma forma necessária de articulação estrutural de um modo específico de acumulação capitalista no quadro de uma economia monopolista.

A especificidade da marginalidade se desenvolver em economias dependentes é que possui uma dimensão quantitativamente ponderável no processo de acumulação de riquezas. Se se considera que nos contextos de dependência se combinam formas produtivas desiguais, os setores marginais revelam-se como um elemento importante de sua expansão. A marginalidade não é um desajuste da acumulação capitalista, mas fruto e função de sua própria lógica. A questão, então, não é a disfunção, mas a contradição que a marginalidade expressa, pois a marginalidade, na verdade, barateia o fator trabalho, aumentando a rentabilidade do empreendimento capitalista. A marginalidade possui o caráter de ser superexcludente (crescentes parcelas não conseguem ser integradas à produção moderna), além de estar articulada à criação e manutenção de relações de produção arcaicas. Agora, não é exatamente a dependência que provoca a margi- 
nalidade; especificamente é o capitalismo que cria formas de inserção marginal na divisão social do trabalho, mas a situação de dependência aguça eventualmente as contradições atreladas a esse fenômeno. Por exemplo, nas sociedades dependentes, a industrialização também é acompanhada e estimulada (pelo papel que tem na acumulação) por formas arcaicas de produção, na qual a mais-valia é produzida por um processo extensivo de superexploração. É a forma como se concretiza esta exploração o que dá parte da especificidade à marginalidade. Os setores marginais proporcionam uma economia de custos altamente compensatória para a acumulação capitalista, pelo barateamento dos custos da reprodução da força de trabalho e pela redução dos custos urbanos de sua reprodução (saúde, saneamento, educação, transporte público etc.) a níveis mínimos de subsistência. "Face a carência de recursos produtivos, em que o único fator abundante é o trabalho, e a necessidade da indústria de se apoiar numa infra-estrutura de serviços para escoar e manter o seu fluxo produtivo, os setores 'marginais' aparecem como um dos pontos de apoio para fazer girar a engrenagem da economia" (KOWARICK, 1975, p. 172).

É em base a esta lógica que Kowarick (1979) cunhará o conceito de "espoliação urbana", talvez o termo que melhor sintetize a discussão urbana paulista da década de 1970. Ela será entendida como uma forma de exploração que corre em paralelo à pauperização do trabalho. A espoliação urbana seria "o somatório de extorsões que se opera através da inexistência ou precariedade de serviços de consumo coletivo que se apresentam como socialmente necessários em relação aos níveis de subsistência e que agudizam ainda mais a dilapidação que se realiza no âmbito das relações de trabalho" (KOWARICK, 1979, p. 59). Embora esse autor veja o urbano como um espelho que reflete os processos da sociedade, a cidade na prática aparece como um amplificador da desigualdade e uma fonte de novas explorações. 
Os recursos estatais se canalizam em função da reprodução e acumulação do capital e não da força de trabalho, graças à dilapidação, por abundância, da mão de obra. A autoconstrução de habitação, enquanto solução de subsistência, contribui ao rebaixamento dos custos de reprodução da força de trabalho, situando-se como um complemento da mais-valia do capitalista, pois é uma forma de trabalho não pago. Mas também é um agudizador das desigualdades espaciais, pois a contrapartida da amplificação da autoconstrução é o descaso de um Estado que não realiza os investimentos públicos em infraestrutura urbana básica. A autoconstrução, nesse contexto, é uma forma de aprofundamento das taxas de exploração da classe operária.

O Estado como investidor seletivo em infraestrutura urbana fortalece as lógicas de especulação imobiliária, possibilitando uma produção do espaço com características segregadoras, por meio de um crescimento caótico da cidade e de periferias urbanas que terminam por aumentar a espoliação urbana das camadas populares. O Estado seria o principal artífice de uma "acumulação primitiva" da terra urbana, mediante a expropriação daqueles que carecem de recursos (econômicos e políticos) e sua expulsão para as periferias distantes. Efetivamente, o melhoramento urbano, via investimento público, normalmente é acompanhado da expulsão dos pobres a zonas desprovidas de serviços públicos, cada vez mais longe dos pedaços da cidade melhor servidos, disponíveis apenas para quem pode pagar os custos do progresso urbano.

Porém, embora a condição de morador urbano não implique o acesso a determinados bens mínimos, abre a possibilidade de sua reivindicação. Esse seria o papel dos movimentos populares urbanos. A pressão desses movimentos por mudar a lógica de produção de desigualdades espaciais sustentaria um potencial exercício da cidadania do urbano. A espoliação urbana também se sustentaria no bloqueio estatal dos canais organizativos autônomos da classe operária, principalmente dos sindicatos, graças à herança burocrática populista, e 
das organizações de bairro (sociedades de amigos de bairro). Sem o controle das iniciativas populares, se dificultaria a alimentação estatal da iniciativa empresarial privada, mediante o favorecimento do capital por sobre o trabalho. Dependerá apenas da capacidade das classes trabalhadoras para se reapropriarem de parte do excedente a possibilidade de melhorar as condições de sua reprodução urbana. Porém, a ameaça de controle estatal está sempre presente, e o Estado desenvolveu um amplo aparelho de controle, seja através da cooptação ou da repressão dos possíveis agrupamentos populares para reivindicar seus interesses. Não obstante a ameaça populista, nestas novas organizações de reivindicação urbana está presente a promessa de superação da lógica de manipulação: o Estado deveria renunciar a seu principal mecanismo para assegurar a acumulação do capital, para assim satisfazer a demanda popular. A luta urbana revela uma contradição que atinge a lógica interna do próprio Estado e do sistema capitalista brasileiro.

\section{São Paulo e a promessa dos Movimentos Sociais Urbanos}

A emergência de uma onda de mobilizações na periferia paulista e a criação de uma série de organizações populares demandantes de moradia, serviços urbanos, creches etc., deslocaram a atenção política para a periferia paulista na década de 1980 . A academia acompanhou este processo não apenas revisitando a literatura sobre movimentos urbanos, mas transformando o cotidiano dos moradores da periferia num objeto privilegiado de estudo (CALDEIRA, 1984). Um grupo importante de autores tomou como ponto de partida e princípio metodológico as situações concretas constitutivas do cotidiano das classes populares. Autores como Eder Sader (2010, pp. 26-7) empreenderam a tarefa de compreensão dos novos padrões de ação coletiva que marcavam a emergência de novos sujeitos políticos e, portanto, de um novo período da história das classes trabalhadoras do Brasil. 
A novidade eclodida em 1978 [com a greve do ABC paulista] foi primeiramente enunciada sob a forma de imagens, narrativas e análises referindo-se a grupos populares os mais diversos que irrompiam na cena pública reivindicando seus direitos, a começar pelo primeiro, pelo direito de reivindicar direitos. $\mathrm{O}$ impacto dos movimentos sociais presentes no cotidiano popular, ofuscados pelas modalidades dominantes de sua representação. Foram assim redescobertos movimentos sociais desde sua gestação no curso da década de 1970. Eles foram vistos, então, pelas linguagens, pelos lugares de onde se manifestavam, pelos valores que professavam, como indicadores da emergência de novas identidades coletivas. Tratava-se de uma novidade no real e nas categorias de representação do real.

Esta nova conjuntura política, marcada pela entrada em cena de novos personagens que alteravam os roteiros preestabelecidos (SADER, 2010), marcará também um novo momento acadêmico. Se anteriormente as ciências sociais, em São Paulo, dedicaram-se à explicação da ausência das classes populares urbanas no cenário político, nesse momento a questão a compreender era sua presença (BRANT, 1982). O que se buscava era capturar as condições de desenvolvimento da consciência, expressão e organização das classes trabalhadoras, nas diversas formas que esta tomou na conjuntura prévia ao fim da ditadura militar brasileira.

Uma ruptura com a literatura paulista, que anteriormente buscou compreender e avaliar o potencial político das classes trabalhadoras (ver capítulo 1) que este novo grupo de pesquisadores estabeleceu, foi tentar ir além da interpretação do caráter amorfo que se atribuía à classe operária e buscar, nas maneiras como os grupos sociais subalternos percebem e definem seus interesses e sua relação com a política, a chave de compreensão desse potencial. Teresa Caldeira (1984) mostrará como na periferia surgia uma maneira de interpretar a história política brasileira ancorada 
na condição de trabalhadores e de pobres de seus entrevistados. $\mathrm{O}$ reconhecimento da emergência de uma política popular que vem da periferia será o resultado desta virada acadêmica.

Esse grupo tomará como referência teórica primeiramente a produção de Manuel Castells e sua $A$ Questão Urbana. Pelo qual, se considerará os MSUs como movimentos que emergem da sociedade civil, com uma composição social heterogênea, mas cujas demandas em torno ao consumo urbano terminam por dar certa homogeneidade de conteúdo a eles. O que os mobiliza são as contradições urbanas, que expressam correlações de forças a partir de interesses sociais antagônicos, dados pela própria estrutura urbana. Originadas pelo processo de acumulação e reprodução do capital e pela urbanização, as contradições urbanas, e a consequente demanda por políticas urbanas do mundo popular, opõem estes movimentos ao aparelho estatal, levando a que suas lutas gerem efeitos na estrutura de classes e na estrutura urbana (GOHN, 1982).

Esta produção teórico-urbana, desenvolvida nos anos 1980 em São Paulo, beberá da teoria dos MSUs de Castells, mas também continuará em linha com o pensamento daqueles autores que nos anos 1970 elaboraram uma interpretação marxista do processo de urbanização em São Paulo: Francisco de Oliveira, Paul Singer, Lúcio Kowarick. Assim, se por um lado se tomará a ideia do potencial político dos movimentos urbanos populares, por outro se reconhecerá que essa importância estaria dada pelas contradições do desenvolvimento capitalista local que condenaria grandes parcelas da população a uma superexploração, colocando o Estado no centro das atenções das classes populares (MOISÉS, 1982).

A superconcentração de atividades produtivas no processo de desenvolvimento capitalista gerou enormes massas de população que foram obrigadas a se acomodarem ao processo de urbanização pela expansão de periferias. A divisão social e espacial atrelada a esse processo foi acompanhada da aparição de uma série de contradições e distorções urbanas, marcadas pela emergência de 
novas necessidades sociais e urbanas para a sobrevivência da população: serviços de infraestrutura, transportes coletivos, sistema educacional, serviços de saúde, equipamentos sociais e culturais etc. Contradições que levaram a uma relação antagônica entre o Estado e as massas.

A tradição populista de manipulação das organizações populares, que na cidade de São Paulo se cristalizou com as tentativas de Janio Quadros de controle das Sociedades de Amigos de Bairro (SABs), reforçou a legitimidade das reivindicações urbanas e, ao mesmo tempo, representou um fracasso na tentativa de atenuar essas contradições, pois o Estado só era capaz de atender às necessidades da força de trabalho de maneira parcial e limitada. $O$ populismo paradoxalmente contribuiu para reforçar a crise de legitimidade do Estado brasileiro, na medida em que espalhou o consenso de que cabe a ele prover a solução aos problemas urbanos, e com isso amplificou-se o antagonismo deste com as classes populares. Isto se agravou com o início da Ditadura e a perda de significado do voto das massas urbanas como principal forma de pressão da população pobre frente ao Estado. Esse antagonismo permitia que os Movimentos Urbanos superassem a dimensão estritamente econômico-corporativista de suas demandas e politizassem suas reivindicações, cobrando centralidade na esfera política.

Embora sejam os protagonistas de uma inserção subalterna também ao nível das relações de produção, é ao nível da superposição imediata dos seus interesses, como consumidores da cidade, que esses moradores apareciam na cena urbana. Entretanto, longe de diluir o conteúdo social inerente às contradições urbanas, a sua heterogeneidade social permitia a emergência de uma unidade face ao antagonista que tratavam de golpear com as suas reivindicações: o Estado (MOISÉS, 1982, p.21). 
Ao existir um alvo claro, o Estado, possibilitava-se a unidade de ação de um coletivo heterogêneo e amplo, as classes populares, $o$ que permitia que estes movimentos aumentassem sua importância pelas potencialidades de articulação política de maneira autônoma dos grupos subalternos. Os movimentos populares politizam e mobilizam uma nova problemática urbana e se estabelecem como interlocutores políticos junto aos órgãos do Estado.

Esta promessa não residia apenas nas formas de ação organizada, que, a partir da segunda metade da década de 1970, começavam a florescer em diversas cidades brasileiras (CEBs, novo sindicalismo, Organizações de Bairro etc.). Este embrião político se apresentava também na ação direta de caráter espontâneo dos "quebra-quebras", formas de depredação ou motim social que, sobretudo a partir de 1974, cobraram relevância política pela sua massividade e certa regularidade, particularmente em capitais como Rio de Janeiro e São Paulo. Embora supostamente erradicados da cena política com o fim da política populista pré-64, os populares reaparecem para manifestar sua rejeição à deterioração de suas condições de existência. Em cada ação direta, essas massas experimentavam sua própria potencialidade como força social e política, pela resposta política e repressiva das autoridades. Nos quebra-quebras existia uma dimensão profundamente política que o regime reconhecia, mas que as ciências sociais ainda não.

Moisés (1983) fará o exercício de recuperar a história dos Quebra-Quebras de 1947, em São Paulo, em pleno varguismo, para traçar uma linha de continuidade no movimento popular, mesmo ignorada pelas ciências sociais e pela esquerda, já que este acontecimento foi postergado e esquecido em ambos os registros. Precisamente, a incompreensão desse evento por parte do Estado e dos partidos preservou o marco de espontaneidade que caracterizava o fenômeno. Os quebra-quebras, mesmo em 1947, instalavam demandas populares a partir de sua própria organização e 
direção. Por assim dizer, eram uma expressão puramente popular que teria passado desapercebida no momento.

Nesse sentido, a nossa hipótese reivindica uma dinâmica própria para as 'explosões selvagens' das massas suburbanas que, na aparência, irrompiam espontaneamente - a partir de condições externas a ela, como o agravamento de suas condições de existência - mas que, em realidade, redefine essa espontaneidade no próprio curso de seu desenvolvimento. Por outras palavras, a nossa hipótese toma os acontecimentos que aparentemente surgem como consequência 'irracional' ou 'anárquica', embora inevitável em face das duras condições de vida a que estão submetidas as massas no contexto do regime autoritário vigente, para, a um nível mais analítico, tentar demonstrar que sua eficácia política tem uma lógica, que opera ao nível dos efeitos que provoca diante do Estado e delas próprias. Esta eficácia, no caso, estaria dada na medida em que, assumindo as características de 'protesto selvagem', não apenas elas mobilizam esse Estado para responder à sua ação (mesmo que essa resposta seja a repressão e a força), mas também afirmam diante delas mesmas a sua própria potencialidade como força social capaz de intervir, de alguma forma, na sociedade. (MOISÉS e MARTINEZ-ALIER, 1978, p. 22).

Para usar um conceito ad hoc, a situação de espoliação urbana, a qual estavam submetidas as camadas populares, permitia que qualquer fator que fosse agudizar suas precárias condições de reprodução, servisse como estopim para a ação direta, criando formas de solidariedade espontânea e capacidade de reprodução (efeito demonstração). Mesmo não sendo organizadas nem possuindo uma orgânica estável, elas têm significado e consequência política: as revoltas respondem a anseios coletivos e deslegitimam o regime ditatorial. Em uma linha similar, María da Glória Gohn (1985) argumentará que os MSUs possuem um caráter dinâmico, 
já que mesmo os movimentos em estados menos desenvolvidos, já conteriam os germes de negação do sistema, gestando práticas nas quais está presente um apelo democrático e novas práticas sociais. Outros afirmavam que:

A emergência dos movimentos populares urbanos com um novo caráter pautado pela autonomia tem como eixo determinante das suas lutas o crescente processo de exclusão dos benefícios da urbanização. Nesse contexto o Estado desempenha papel fundamental no processo espoliativo, em decorrência da orientação excludente da política de investimentos públicos, tornando-se gradativamente o principal responsável pela precariedade da população, que cada vez mais é relegada a uma situação de 'moradores subalternos', sem direito ao usufruto das benesses da urbanização (JACOBI, 1983, p. 150).

Um dos problemas teóricos reconhecido pelos próprios intérpretes dos MSUs é a amplitude da definição, podendo ser considerado como MSU praticamente qualquer forma de luta urbana, e faz com que a categoria perca força explicativa ao virar uma somatória de tão variadas manifestações. Para Ana Maria Doimo (1984), um MSU deverá conter germes de transformação, pelo qual precisa ser compreendido na sua relação com outras lutas populares, o que seria a chave do seu alcance político, enfatizando, portanto, a compreensão destes como expressão particular dos conflitos de classe. Um exemplo disto seria a relação entre os movimentos populares urbanos e as greves do ABC paulista (73-74), onde as articulações com o movimento operário alcançaram seu máximo potencial para o sucesso da greve e para a consolidação dos MSUs.

Esses movimentos apareceram numa conjuntura aparentemente desestimulante, pelas condições de repressão contra qualquer forma de manifestação política por parte da Ditadura, oca- 
sionando que os movimentos iniciaram-se defensivamente e de maneira fragmentária. Por outro lado, o bloqueio dos canais institucionais de representação popular estimulou o cultivo de laços primários de solidariedade na sobrevivência diária da população, sendo as organizações uma extensão destas formas sociais e uma sorte de refúgio ante um clima de medo e repressão. Do ponto de vista organizativo, esses movimentos deram-se a tarefa de substituir os canais de representação oficial, que no contexto autoritário tinham virado inúteis; assim, o caminho da autonomia apareceu quase como inevitável. Ao mesmo tempo, o estabelecimento de dinâmicas democráticas no interior dos movimentos, com assembleias resolutivas, valorização dos processos de conscientização e consultas diretas, transformaram os participantes destas organizações já não em massa de manobra, mas numa soma de indivíduos conscientes e responsáveis por si mesmos. A democratização da organização popular de base aparece como o primeiro passo da democratização da sociedade no seu conjunto:

A incorporação dos grupos de base em movimentos mais amplos, quer tenham sido construídos de baixo para cima, quer constituam estruturas antigas transformadas por sua ação, está alternando fundamentalmente a correlação de forças sociais e políticas na Grande São Paulo. Os novos movimentos sociais apresentam-se como a base possível de uma real democratização da sociedade, não só pelo conteúdo popular de suas reivindicações, mas também pelas formas democráticas que conseguiram criar diariamente, a despeito de instituições ditatoriais e de uma repressão sem regras nem freios (BRANT, 1982, p. 20).

Os MSUs desafiavam as lógicas populistas como nunca antes o Movimento Operário conseguiu fazer. A lógica de cooptação ou de intercâmbio de apoio político por benefícios urbanos aparece, ao menos, como imoral ante os olhos desses movimentos. Nes- 
se processo, a Igreja Católica teria funcionado como um espaço privilegiado de rearticulação das classes populares que favoreceu e incentivou sua autonomia (LESBAUPIN, 1980).

Os diferentes autores que estudaram os movimentos sociais brasileiros na década de 1970 e 1980 coincidiram na avaliação do papel central das Comunidades Eclesiais de Base (CEBs) na articulação desses movimentos (GUIMARÃES DE CARVALHO, 1991). As CEBs foram uma das expressões mais avançadas de uma Igreja Católica que, inspirada no Concílio Vaticano II (1965) e na Conferência de Medellín (1968) do episcopado latino-americano, no contexto autoritário, reafirmou a opção preferencial pelos pobres, não apenas emprestando apoio e respaldo aos perseguidos pela Ditadura, mas se envolvendo diretamente na defesa dos direitos humanos, bem como estimulando a organização popular de base.

As CEBs não apenas estavam inspiradas na Teologia da Libertação (ROWLAND, 2000), como foram sua principal plataforma divulgadora e uma de suas expressões mais originais, e tiveram no Brasil um contexto único de desenvolvimento. A Teologia da Libertação estabelecia um diálogo entre a tradição cristãa a análise social e a autoanálise que pobres e marginalizados faziam de sua própria situação, em prol de uma mudança social que melhorasse a situação destes últimos. O ponto de partida desta teologia é a vida cotidiana dos oprimidos, que é interpretada através da Bíblia: o martírio do seu cotidiano revela a presença de Cristo, a experiência popular torna-se caminho de aproximação com Deus, trazendo como consequência a autoconsciência do sujeito popular como tal. Nas palavras de Gustavo Gutiérrez (2000, p. 43): "estamos ante algo desafiante e em muitos aspectos promissor que tem feito que $o$ pobre comece a se olhar como sujeito de sua própria história, como alguém que tem começado a tomar nas suas mãos as rédeas do seu destino". 
No começo da década de 1980 , as CEBs tinham proliferado de tal maneira que seu número estimava-se em 50 mil em todo o Brasil. Alguns dos estudiosos desse fenômeno assinalaram que: "sua importância está no fato de constituírem uma promissora trama de experimentação e de exercícios sistemáticos de formas novas de associação popular para a discussão e busca de soluções dos problemas vitais que, no campo e nas periferias das grandes cidades, afligem as classes trabalhadoras" (CAMARGO et al., 1982, p. 62). As CEBs são consideradas como uma das principais divulgadoras da cultura democrática que se gestava no campo popular naquela conjuntura. $\mathrm{O}$ estímulo de uma consciência crítica frente a uma realidade opressora, o estabelecimento de dinâmicas horizontais e autovalorativas (fraternidade comunitária) e a promoção da constituição de redes de reflexão e ação marcaram a capacidade organizativa e reivindicativa que foi irradiada desde as CEBs para outras formas de organização popular. Essa autovalorização do sujeito popular, mediante a reflexão crítica de sua própria experiência, mudaria a relação que tradicionalmente se deu entre as classes no Brasil, particularmente entre as camadas populares e as mais abastadas. O próprio apoio eclesiástico aparece, para estes autores, mais do que um agente mediador, um aliado que se coloca do lado das bases.

A aparição das CEBs, para Paul Singer (1982a, p. 89), terá o papel de provocar uma ruptura entre o antigo movimento de bairro, ligado às Sociedades de Amigos de Bairro (SABs) controladas pelo janismo (Jânio Quadros) e o novo movimento de bairro nesta cojuntura. Os movimentos nos bairros terão a dupla condição de ser uma forma de coesão e solidariedade popular e um espaço de luta pelo melhoramento das condições de vida através da obtenção de "bens coletivos" para a comunidade urbana. As CEBs em muitos casos foram a organização matriz do Movimento de Bairro de São Paulo, inspiradoras e suportes, em geral, das mais diversas organizações sociais aparecidas nesse período. Assim: 
Os moradores de bairros operários novos tendem a desenvolver formas de solidariedade mútua para suprir, por iniciativa própria, certas carências básicas. A organização para reivindicar benfeitorias e serviços, que não podem ser alcançados pela ação própria dos moradores mas dependem da ação do Estado, deve ser vista como decorrência destas formas elementares de auto-ajuda. É da interação destes dois tipos de atividade - para dentro e para fora - que surgem as contradições de classe no seio do próprio movimento de bairro, que levam à crise de sua primeira forma de organização - a $S A B$ - e a sua superação, mediante a criação de novas modalidades de organização, diretamente inspiradas pelas Comunidades Eclesiais de Base (CEBs) da Igreja Católica, com participação eventual de outras igrejas ou grupos ideológicos motivados.

As classes populares organizam seus interesses a partir das contradições urbanas ou mais especificamente graças ao "viver as contradições urbanas" como experiência de conscientização social.

A Igreja se constituiria assim em um núcleo agregador de interesses de setores populares, propiciando a generalização de um sentimento de solidariedade local, baseado numa identidade de interesses da população do bairro. Esta solidariedade possibilita não só um maior grau de coesão entre os moradores, como também contribui para a formação de uma consciência social, estruturada a partir de uma experiência de vida comum, cujo substrato são as precárias condições enfrentadas na cidade. Isso porque as discussões sobre suas condições urbanas de vida abrem um espaço para a articulação de reivindicações, antes individuais e subjetivas, e que cada vez mais adquirem uma expressão coletiva generalizada (SOUTO, 1983, p. 76). 
As CEBs são para Souto, assim, um movimento de leigos que também democratiza a Igreja, agora nascida das bases. A Igreja não é política, porque não está vinculada a partidos políticos, outorgando uma garantia de independência para a manifestação livre dos problemas do bairro.

A partir da influência das CEBs, as SABs enfrentam a disjuntiva entre continuar perpetuando o status quo ou se deixar permear pelas lógicas autonomistas dos novos movimentos. A influência das CEBs termina por modificar as SABs, mas também a própria prática popular de reivindicar melhoras urbanas termina por questionar sua própria lógica tradicional:

As SABs representam ou implicam um grau de articulação elementar das classes populares. Esta articulação é obtida, não através de solidariedade econômica corporativa, mas de uma solidariedade advinda de interesses urbanos comuns, e da identificação do pólo de luta para obtenção destes interesses comuns, ou seja, o Estado. A mobilização e a articulação que as SABs expressam refletem um processo embrionário de formação de uma vontade coletiva popular, que se manifesta como movimento de antagonismo entre setores populares e o Estado (GOHN, 1982, p. 166).

Considere-se como exemplo disso os movimentos sociais urbanos de mulheres. Consideradas responsáveis pelo cuidado da casa e da família, elas foram impelidas a sair às ruas para reivindicar uma redução no custo de vida (Movimento Contra a Carestia) ou para exigir a construção de creches (Movimento de Creches) para resolver a situação das crianças que ficavam sozinhas em casa. A partir de sua condição como mães e das expectativas que a própria sociedade estabelecia sobre elas (mães protetoras do lar), as mulheres abriram espaços reivindicatórios por vias não correntes, relacionando numa mesma prática polis e oikos (BLAY, 1980). 
O Estado também se vê obrigado a responder à pressão popular com algo mais que tentativas de cooptação, o que termina por reformular e readequar suas ações em matéria urbana, o que é indicador da influência das lutas urbanas nas práticas político administrativas. Ou, ao menos, a mobilização das classes populares, via MSU, termina por substituir o poder público no atendimento de necessidades criadas para a reprodução da força de trabalho no meio urbano (habitação, creches, escolas, mutirões etc.) (GOHN, 1982).

O surgimento de todos estes movimentos mostra que parcelas crescentes da classe trabalhadora de São Paulo estão tomando consciência das contradições entre suas necessidades, como seres humanos e como grupos sociais, e as possibilidades de satisfação que as estruturas sociais vigentes lhes abrem. As lutas destes movimentos têm em comum o objetivo de alterar essas estruturas que travam suas possibilidades de autorrealização, sejam elas a subordinação dos sindicatos ao aparelho do Estado, o funcionamento do mercado imobiliário (que impede o acesso dos mais pobres aos serviços urbanos) ou o funcionamento do mercado de trabalho (que permite a discriminação sexual e racial no mundo do trabalho, sem que sua prática sequer possa ser comprovada de modo a poder ser denunciada e combatida) (SINGER, 1982b, p. 213).

Em relação à autonomia, uma verdadeira obsessão para estes autores, embora não seja sempre vista como uma realidade trazida totalmente à tona pelos movimentos, é entendida como um processo de avanços e recuos na prática cotidiana. Assim, não obstante possam reconhecer que uma autonomia total não existe, efetivamente a estabelecem como uma meta a ser alcançada e da qual depende a continuidade do próprio movimento. 
A autonomia nos movimentos populares não é algo dado, um estado de ser, mas algo a ser conquistado. Trata-se da busca, da conquista do novo, da luta contra o velho (os privilégios, a manipulação, a cooptação). Ela se manifesta na criação de novas formas de ação, organização, consciência; é importante aos movimentos populares porque - uma vez conquistada - tornará os movimentos fortes e dinâmicos, os quais saberão resistir às investidas das classes dominantes no sentido de desarticulá-los (GOHN, 1985, p. 41).

Agora, esta observação de Maria da Glória Gohn será interessante também porque é a base da crítica que a autora faz ao papel da Igreja Católica nos movimentos sociais, pois embora nos setores progressistas do catolicismo se destaque a questão da fala do oprimido e do saber popular, muitas vezes há um controle da fala por parte da Igreja, a qual teria que lidar com sua lógica hierarquizada para contribuir a uma verdadeira autonomia dos movimentos populares.

Em relação ao papel da Igreja nos movimentos populares urbanos, Sergio Lopes (1980) questionará o fato de que mesmo sendo a autonomia uma preocupação dos agentes pastorais, ela nem sempre opera na prática. A pedagogia libertadora presente na dinâmica das CEBs também supõe a presença de "agentes" pastorais que possuem uma prevalência por sobre o movimento. Por outra parte, nas leituras autonomistas e espontaneistas existia uma subestimação do potencial do Movimento Sindical, omitindo o papel de trabalhadores com experiência sindical na pastoral popular e, como contraposição, uma superestimação do caráter pouco institucionalizado do movimento.

"Até que ponto a acentuada defesa da autonomia dos Movimentos Populares - enfatizada pelos agentes pastorais em relação aos partidos políticos e ao Estado - não acaba por isolá-los num espaço limitado controlado pela própria igreja?”, era o que se per- 
guntava Ana Maria Doimo (1984, p. 104) paralelamente. Na sua pesquisa sobre o Movimento de Transporte Coletivo (MTC) de Vila Velha em Espírito Santo, ela salientará que a estrutura organizativa descentralizada do movimento, mas vinculada à estrutura pastoral, não apenas permitia a formação de consenso, como seu controle. A Igreja não somente controlava o movimento e cooptava suas lideranças emergentes para o trabalho pastoral, como a sua sobrevivência dependia da Igreja. Apesar do discurso glorificador da autonomia entre os agentes pastorais e nas lideranças sociais, esta era relativa e limitada pela presença da própria Igreja. Porém, o seu papel nas transformações do cotidiano das relações sociais, dos valores e das posturas políticas do movimento era inegável.

Não há como negar que foi na nova forma ritual de organização da Igreja e no sentido ético-político do seu discurso religioso que residiu o fator básico da capacidade de mobilização popular e de participação continuada dos componentes do MTC, superando a existência de muitos dos entraves à organização popular a nível dos bairros. E não há como deixar de sugerir que é dessa forma que a Igreja continuará a influir nos Movimentos Populares, mesmo defendendo a sua autonomia em relação aos partidos políticos, ao Estado e, principalmente, a ela própria (DOIMO, 1984, p. 111).

Começa a se gestar neste ponto uma série de críticas internas ao "paradigma" dos MSUs. A politização do processo de urbanização efetuada pelos autores, inicialmente se sustentava no diagnóstico estrutural econômico que realizaram da década de 1970. A ampliação das condições de espoliação urbana tenderia, portanto, a pôr em xeque a dinâmica do próprio capitalismo, na medida em que a redução ao mínimo das condições de reprodução da força de trabalho era necessária à acumulação do regime. Como este "otimismo catastrófico" (KOWARICK, 1987) não se 
observou na prática, o interesse dos pesquisadores se deslocou para a novidade cultural dos MSUs. Neste ponto, a noção de Novos Movimentos Sociais de Touraine começa a ganhar força. Porém, isto não significou uma quebra epistemológica dentro do campo de estudos dos MSUs, em parte, porque a essa altura o próprio Manuel Castells (1986) começava a diluir seu conceito de MSU na categoria de Novos Movimentos Sociais. Desta maneira, produzir-se-á uma transição desde a valorização dos MSUs pelo seu potencial revolucionário, para sua valorização pelo potencial democrático que ofereceriam.

Segundo Durham (1984), muitas das dificuldades teóricas encontradas pelos intelectuais na análise destes movimentos correspondiam ao não cumprimento das expectativas de comportamento esperadas pelos próprios analistas em relação a como se dariam as transformações políticas atribuídas aos mesmos movimentos (visão apriorística da história). Para a autora, era preciso superar a visão evolucionista que vê os movimentos sociais como formas embrionárias de estágios superiores de organização social (partidos ou sindicatos), uma vez que os movimentos sociais não são um substituto empobrecido de um movimento verdadeiro ante o fechamento do sistema político. Não é a pobreza ou a "espoliação urbana", mas a consciência da situação de privação relativa, a que opera como fator de mobilização. Os movimentos sociais não são apenas formas defensivas ante a miséria da população, mas um apelo à ampliação da esfera política do país e ao acesso aos benefícios do crescimento econômico. Já que sua importância é cultural, os movimentos não podem se restringir unicamente ao popular e devem buscar a amplitude representada por outros movimentos, como o feminista, o negro ou o ecologista. A heterogeneidade dos movimentos sociais supõe um desafio teórico que categorias como "exército de reserva" ou "classes populares" não permitem dar conta, da mesma maneira que a análise a partir da "reprodução da força de trabalho" não dá conta 
do desafio cultural que estes movimentos representam. Isto é, a capacidade de um movimento heterogêneo reconhecer-se como comunidade na ideia de "igualdade" frente a uma carência. A vivência de comunidade ou coletividade permitiria o reconhecimento da pessoa num plano público e não privado, pelo reconhecimento mútuo dos indivíduos, potenciando sua condição de sujeitos. $\mathrm{O}$ que está em jogo, então, é uma nova forma de cidadania baseada na afirmação de direitos, mais do que carências.

Para Timan Evers (1984) o potencial transformador dos novos movimentos sociais é sóciocultural antes que político, ou seja, sua novidade estribava na criação de pequenos espaços de prática social, onde o poder seria uma questão secundária. Estes movimentos propunham uma renovação sóciocultural do cotidiano através da construção de uma identidade autônoma que desafiava as práticas de tutelagem tradicionais da política, tanto do paternalismo populista como do vanguardismo leninista, onde o papel dos movimentos sociais reduz-se a organizações de massa que devem ser guiados para a revolução. "A capacidade inovadora desses movimentos parece basear-se menos em seu potencial político e mais em seu potencial, para criar e experimentar formas diferentes de relações sociais quotidianas" (EVERS, 1984, p.15). Estes movimentos desenvolveriam dentro de si mesmos os fragmentos de um novo "ser sujeito" que propõe uma cultura popular descentralizada, alternativa e autônoma ao capitalismo. Na definição de Eder Sader (2010), estes sujeitos coletivos se caracterizariam por ser coletividades que elaboram uma identidade originada na prática cotidiana e na experiência de defesa de seus interesses e expressão de suas vontades através das lutas.

Assim, estes movimentos (CEBs, organizações de bairro e o movimento feminista) foram considerados como o marco de aparição de "novos movimentos sociais" na ditadura militar, possuindo um papel significativo na luta pela democracia. Por um lado, teriam contribuído para a erosão do regime militar e, além do mais, teriam sido portadores de uma cultura política democrá- 
tica que marcava uma ruptura com a cultura autoritária presente no sistema político brasileiro historicamente (MAINWARING e VIOLA, 1984). A ruptura seria também com os velhos movimentos sociais, cujas demandas seriam meramente materiais - suas relações instrumentais e verticais - e estariam dirigidos ao Estado. Em contraste, estes novos movimentos se preocupariam pelo afetivo, estabeleceriam relações expressivas e horizontais, sendo suas demandas não apenas materiais, mas identitárias. Embora os movimentos urbanos que demandam infraestrutura conservem algumas das características dos antigos movimentos, sua novidade estará dada por manterem um alto grau de autonomia frente às relações clientelísticas tradicionais e frente ao Estado. Aliás, a crise do populismo causada pela ditadura seria um dos fatores que possibilitariam sua aparição, assim como a crise da esquerda tradicional de matriz leninista. Porém, com a abertura dada pela transição democrática, a influência dos partidos políticos reemergiu, tirando o protagonismo dos movimentos sociais, o que mostrou que, embora fundamentais no processo de democratização, sua influência foi limitada. Paradoxalmente, a ascensão da oposição à ditadura com a qual os movimentos se identificavam significou, em muitos casos, uma desmobilização deles.

Contudo, o principal potencial dos "novos movimentos sociais" estaria dado pela construção e desenvolvimento de uma cultura política de base (SCHERER-WARREN, 1987). A identidade destes movimentos se sustentaria no seu autorreconhecimento como "povo" (e não apenas como classe num sentido restritivo) submetido a diversas formas de opressão por parte do capitalismo e na internalização de uma cultura crítica frente à opressão e às diversas formas de autoritarismo (incluindo o da própria esquerda tradicional). Seria um "fato cultural" o que daria forma à organização e práxis dos movimentos; essa seria especificamente sua novidade. 
Estes novos movimentos se caracterizam por suas lutas para romper com os esquemas populistas do passado, para a criação de formas comunitárias de participação direta das bases ao nível da reflexão, da decisão e da execução, diminuindo ao mínimo a distância entre direção e base do movimento. Defendem sua autonomia frente ao Estado e Partidos, considerando a cidadania um direito do povo, numa situação de um capitalismo particularmente excludente. A defesa da autonomia não significa que o partido não poderá ser utilizado como um canal de encaminhamento das reivindicações dos movimentos sociais. Significa, sim, que esses novos movimentos recorrem aos partidos de forma distinta da habitual aos movimentos tradicionais, nos quais havia um nítido atrelamento do movimento ao partido e, frequentemente, ao Estado. Essa nova prática, contudo, não se encontra isenta de ambiguidade, na medida em que frequentemente o líder do novo movimento social é igualmente um líder partidário. Por outro lado, isso tem trazido para os partidos a consciência sobre a necessidade do respeito à autonomia das instâncias (SCHERER-WARREN, 1987, p.42).

Os novos movimentos sociais aparecem como a contrapartida e, em certo sentido, como a resposta à crise das formas tradicionais de fazer política: a instrumentalização do populismo, as organizações centralizadoras (partidos e sindicatos) e a estratégia da esquerda tradicional (luta armada e eleitoral). A revolução no cotidiano que estes movimentos propunham requeria a criação de uma teoria política que superasse a tradição da esquerda, na qual os sujeitos populares se reencontrassem com sua própria agência, rejeitando as lógicas centralizadoras, representativas e alienantes dos partidos de esquerda tradicional. Os novos movimentos permitiriam o exercício de uma utopia concreta e diária na prática política dos sujeitos populares, segundo Kärner (1987, p. 33): 
Com uma nova concepção política, que não está apenas voltada para a conquista de um futuro melhor distante - mas que levanta como meta a realização de uma existência cotidiana digna de viver, e que se vai obtendo também a cada dia -, começa a luta pela eliminação da alienação cotidiana. Esse processo inclui a possibilidade de ensaio de formas de comportamento a longo prazo - e não apenas num sentido econômico - e de desenvolver níveis da existência, que embora não realizem ainda o ideal de uma sociedade horizontal, não hierarquizada e igualitária, o tornem mais próximo, sob condições específicas [...] Esta luta não representa, para o morador, a conquista do poder (estatal), nem a formação de um partido, a hierarquização dos processos de decisão, ou a guerrilha, o fuzil e a violência heroica do soldado. Mas significa tratar de criar, de viver mais humanamente, não mais se deixar alienar dos outros, realizar diariamente atos de solidariedade, pensar e se comportar como se estivéssemos vivendo uma verdadeira democracia.

Os movimentos sociais urbanos seriam intrinsecamente democráticos, basicamente porque estariam pautados pela autonomia e porque, na sua luta contra a exclusão dos benefícios da urbanização, democratizaria também a cidade, propondo formas de gestão mais inclusivas (NUNES e JACOBI, 1983). Também a questão da autonomia implicaria a admissão da pluralidade partidária no seu seio e um primeiro impulso para que esta fosse aceita na esfera política nacional.

A própria presença destes movimentos implica na exigência de participação e o seu desenvolvimento coloca em questão a democracia. A partir daí, é um caminho sem retorno: ou o sistema político se abre à participação dos movimentos ou não se poderá falar em democracia. Sua supressão implicará em ditadura. O que é novo nos movimentos populares urbanos é que eles não mais se 
submetem à cooptação, a uma participação subordinada (NUNES e JACOBI, 1983, p.57).

Nas avaliações otimistas do fim deste ciclo, os movimentos sociais das décadas de 1970 e 1980 instituíram-se como formas de expressão e passaram a constituir parte da vida política do país. Embora sua promessa inicial não se concretizasse, efetivamente construíram uma memória coletiva que eventualmente poderia reatualizar essa promessa, possibilitando a realização de uma verdadeira democracia (SADER, 2010).

\section{Rio de Janeiro e a perspectiva Anti-Movimentos Sociais Urbanos}

Interessados também na coincidente aparição de movimentos coletivos urbanos e no início do processo de redemocratização, um grupo de pesquisadores do Rio de Janeiro estabelecerá uma perspectiva analítica bastante diferente da que primou na academia paulista. Rejeitando as noções contidas no campo de estudos dos Movimentos Sociais Urbanos, construíram um contraparadigma que, sem ser totalmente pessimista, foi cético em relação ao potencial político dos movimentos urbanos anunciado pelos autores anteriormente revisitados. Uma das críticas aos MSUs é que não consideravam suficientemente a especificidade do caso brasileiro, por estarem inspirados na realidade francesa e espanhola (CASTRO, 1983).

Autores como Renato Boschi, Eli Diniz, Carlos Nelson Ferreira dos Santos e Lícia Valladares desenvolveram uma compreensão alternativa dos movimentos urbanos que privilegiará a análise institucional, as condições que facilitam ou obstaculizam a mobilização social, assim como uma perspectiva utilitarista sustentada na tradicional figura do "jogo político" da favela. Por outra parte, outros autores como Luiz Antônio Machado e Ana Clara Torres 
Ribeiro realizaram uma crítica teórica a partir da lógica interna do que entenderam como o paradigma dos MSUs.

A abordagem desenvolvida por esses autores foi classificada por um dos membros do grupo de São Paulo como perspectiva da "Institucionalização", sendo considerada como um enfoque neoliberal e até ambíguo, por atribuir ao Estado a capacidade de regular conflitos e dinamizar a participação social na sociedade, o que seria contraditório com a prática do Estado, orientada à dissolução de conflitos e a representação de interesses antagônicos às forças populares (GOHN, 1985).

Assim, como nos anos 1970 os estudiosos da questão urbana deram-se a tarefa de desmitificar a Teoria da Marginalidade, reutilizando muitas das noções herdadas dessa crítica, na década de 1980, a tarefa foi desmitificar a teoria dos MSUs. A seguir, serão apresentados alguns dos principais intérpretes desta leitura.

\section{A leitura alternativa: institucionalidade e utilitarismo}

Em uma ampla pesquisa sobre movimentos urbanos de favelas e periferias de áreas metropolitanas de diversas cidades brasileiras, Boschi e Valladares (1983) tentaram decifrar as características que possibilitavam a mobilização popular urbana, o porquê de algumas experiências terem sido mais bem sucedidas que outras e quais eram os fatores que permitiam a durabilidade no tempo de uma organização. Os conflitos que estudaram mostraram que o contexto de estruturação desordenada do espaço, assim como a existência de uma acentuada segregação espacial, formatadora de desigualdades e de identidades, eram parte do contexto possibilitador da mobilização. Nelas, a questão de classe era secundária frente à importância do espaço imediato de moradia como ligação de natureza mais permanente e de onde emergem fatores aglutinadores conducentes à criação de uma identidade coletiva. 
Agora, não é a situação de pobreza absoluta a que os mobiliza, e sim uma situação de privação relativa frente a determinados direitos básicos que podem ser conquistados, pelos quais as transformações revolucionárias não estão na pauta impulsora dos movimentos. $\mathrm{O}$ movimento muitas vezes se define por ameaças externas (remoção) e se consolida pela mediação de agentes de fora, que agem como catalizadores e direcionadores da atuação coletiva para um alvo determinado. Embora os agentes externos possam propulsionar, em determinados casos também podem conter. A questão da autonomia está marcada, por um lado, pela presença e tutela destes agentes externos e, por outro, por um marcado discurso autonomista que contradiz as dependências que estas organizações desenvolvem.

As mobilizações também teriam um ciclo de vida determinado, já que elevados níveis de participação não se sustentam ao longo do tempo. A maior parte dos movimentos que estudaram foram "movimentos bem sucedidos" que conseguiram, embora parcialmente, a satisfação de suas demandas, com o que a motivação para a mobilização esgotava-se com a vitória. A atuação coletiva pode adquirir uma dimensão rotineira que permita sua extensão no tempo, mas a incorporação de lógicas institucionalizantes rivaliza com o discurso das próprias organizações.

Nestas lutas, o Estado nem sempre é identificado como alvo direto da mobilização coletiva, mas é um dos propulsores, pela sua inoperância no fornecimento de serviços coletivos e na garantia de direitos mínimos. E, embora o Estado funcione como um fator de contenção nos processos de negociação que seguem a mobilização, a relação com o Estado está longe de ser polarmente antagônica.

Já uma década antes, Boschi vinha realizando pesquisas nas quais afirmava que o comportamento político do favelado não é nem apático nem radical. Referia-se às formas de integração política dos indivíduos, ou seja, fatores externos e internos que configuram o padrão de comportamento político do favelado. 
Não há razão plausível para se pensar que o favelado, enquanto elemento das camadas baixas da sociedade, deva apresentar certos valores de participação que são próprios das classes médias. Por que pensar que o favelado necessariamente deva interessar-se pela política governamental em aspectos que são distantes de sua experiência de vida? Por que pensar que o favelado necessariamente deva entender do funcionamento do sistema da mesma forma que um indivíduo de classe média e, ao constatar-se as diferenças, atribuir-lhe um baixo grau de participação ou apatia política? (BOSCHI e GOLDSCHMIDT, 1970, p. 5).

O conceito chave era o de integração política, entendida como uma forma de participação adequada às necessidades e demandas dos favelados, onde eles avaliam certas possibilidades de solução que sejam eficazes a curto e longo prazo, como a participação numa Associação de Moradores para defender-se de ameaças externas (remoções). Por que o favelado teria que se preocupar com questões políticas que não estejam diretamente relacionadas com sua luta cotidiana pela sobrevivência? Isso não nega a possibilidade de que o favelado possa ter um interesse mais amplo em relação ao mundo político, mas existe uma questão política anterior, a da sobrevivência.

Dando continuidade a essas pesquisas e mobilizando um marco teórico de matriz norte-americana, Renato Boschi (1983) atualizará o debate sobre utilitarismo e introduzirá Tilly (1995) e a Teoria de Mobilização de Recursos (BRINGEL, 2012) na análise dos movimentos coletivos brasileiros. Assim, o autor compreenderá os movimentos urbanos a partir de duas dimensões: a formação e penetração do Estado e os fatores propulsores da ação coletiva. Sua preocupação central será o impacto político institucional dos MSUs. A despeito da literatura da época que, principalmente em São Paulo, compreendia estes movimentos, estabelecendo uma polarização - "ou se tem uma sociedade altamente mobilizada (de 
baixo para cima), ou manipulada e induzida pela atividade estatal (de cima para baixo)" (BOSCHI, 1983, p.50) -, este autor se centrará nos repertórios de ação coletiva, mas entendidos como respostas à progressiva monopolização de aspectos da vida social por parte do Estado. Nessa interação, existiria uma relação tensa de contraponto, mas não necessariamente de antagonismo.

Para Boschi (1983, p. 6), a literatura dos MSUs sistematicamente ignorou a pergunta pelo impacto da ação coletiva na institucionalidade, transmitindo a ideia de uma sociedade altamente mobilizada (verdade parcial), considerando esta mobilização como indiscriminadamente progressiva, outorgando à participação um caráter de fim em si próprio e reconhecendo na mobilização permanente um antídoto à cooptação estatal.

Os nexos com o aparelho do Estado, a um tempo como gênese dos movimentos e como sua razão de ser no sentido de abertura de espaços de representação política, são sistematicamente descartados como um quadro dentro do qual a transformação política pudesse ser pensada teórica ou praticamente, ainda que a omissão do Estado na área de políticas públicas vitais seja unanimemente apontada nos estudos como alvo direto da atuação dos movimentos, isto é, o Estado visto como 'condensador' das contradições que favorecem a emergência do protesto ou reivindicação, e ainda que o insatisfatório desenvolvimento conceitual neste particular seja apontado em vários trabalhos. Institucionalização, como quer que se a defina, é uma palavra no geral banida do léxico desta literatura como algo suspeitamente identificado como o status quo; em lugar disso prevalece o furtivo namoro com o movimento enquanto tal, como algo a ser preservado em estado puro, destituindo-o, portanto, de seu caráter processual e - diga-se de passagem - dialético. 
Embora o autor reconheça que as novas formas de associativismo urbano estariam expressando a constituição de novos atores políticos e de um estilo de participação que pode rivalizar com os padrões institucionais vigentes, considerou que o impacto institucional seria mais reduzido do que aspiravam seus analistas. A incorporação como atores políticos legítimos e a institucionalização de suas práticas em termos de canais permanentes de acesso ao Estado não parece evidente, pois muitas de suas demandas são particularistas, sua força e peso variável e sua presença descontínua. Porém, os movimentos sociais ampliam o repertório para a manifestação de interesses de parcelas sub-representadas da sociedade, mas não como uma alternativa excludente ao processo eleitoral è̀ estrutura partidária.

No seu estudo sobre associaçóes de moradores de favelas do Rio de Janeiro, Eli Diniz (1983) chegará a várias conclusões significativas para este contraparadigma. Considerando estas associações como o principal instrumento de articulação dos interesses favelados e como a principal instância de mediação frente ao Estado, ela mostrará que o número de associações varia significativamente e é altamente sensível à política estatal sobre as favelas. Aumentando nos momentos de ameaça de remoção, declinará com a crescente legislação restritiva voltada para o controle das associações (196770) e novamente se incrementará com a abertura política e o início de uma orientação favorável à implementação de programas voltados para a urbanização das favelas (1978-79). O ciclo de vida das associações será descontínuo; a maioria delas mostrará ao menos uma interrupção em seu funcionamento. Ao mesmo tempo, as lideranças de associações mostravam um predomínio de orientações menos ideológicas, assim como um padrão menos combativo no seu estilo de ação e capacidade reivindicativa. Predominaria entre as lideranças um baixo grau de socialização com outras formas de participação organizadas fora do contexto da favela (por exemplo, sindicatos), bem como existiria uma baixa interação com outras 
organizações da favela, excetuando as relações com a Igreja Católica. Esta instituição ocuparia uma posição mais central na capacidade para estabelecer vínculos com outras formas de organização coletiva. Se a favela é um espaço de disputa de organizações concorrentes, as associações de moradores mostram muita fraqueza na hora de tentar impor uma liderança sobre as outras instâncias.

Em relação ao discurso das lideranças, Diniz será clara ao afirmar que nenhuma entrevista revelou uma percepção do favelado como pertencente a algo assim como uma "classe popular" ou uma "classe trabalhadora oprimida", embora se reconhecesse a situação de favelado como a mais específica forma de marginalidade social. A política é vista como uma atividade vazia e estéril que não oferece possibilidade de mudança substancial nas condições de vida da população favelada e o papel do político é visto como negativo para a favela. Reconhecem, sim, que é possível aproveitar as brechas abertas pela política, através de relações pessoais de lealdade com um determinado político. Atualiza-se assim a figura do “animal político" favelado à la Leeds que instrumentaliza a política para conseguir ganhos coletivos ou individuais, mas que paralelamente desenvolve uma visão cética das possibilidades oferecidas pela política para mudar sua situação.

Os diferentes autores deste grupo mostraram que, a despeito da leitura paulista, onde o jogo político de dupla manipulação teria sido superado pelos novos movimentos urbanos, este continuava operando nas favelas cariocas, durante um período, substituindo o político pelo burocrata do Estado, mas, posteriormente, com a abertura do regime militar, pelo político que subia novamente o morro. A título de ilustração, é possível citar um trecho de uma entrevista realizada a uma liderança da FAFERJ, Benedito de Macedo:

É um intercâmbio que funciona mais ou menos assim: um político se dirige a mim e pergunta qual a maior carência da minha 
comunidade, no momento. Eu digo que é telha para cobrir o galpão e ele então diz que envia e pede que seja marcado um dia para inauguração, da qual será padrinho. Quer dizer, ele impõe o que quer e como nós estamos necessitados daquilo, aceitamos. Há também um tipo de político, que tem aparecido no Rio ultimamente, que tem uma grande comunidade, por exemplo, do Borel, onde envia todos os domingos um carro de uma empresa de laticínios que distribui Danone e leite concentrado para as crianças [...] É um jogo de barganha porque, como os políticos são inteligentes não devemos esquecer que os presidentes, mesmo de comunidades carentes são brasileiros e também inteligentes como eles e sabem fazer o jogo deles. Às vezes fazem negociata com dois ou três partidos e alertam o povo (apud PFEIFFER, 1983, p. 15).

A maior expressão desse jogo foi, na época, o chaguismo, que, segundo Eli Diniz (1982), foi uma prática política carioca que, durante a ditadura, institucionalizou a troca de apoio (principalmente votos) por vantagens particulares, concedidas por representantes públicos. Em outras palavras, o chaguismo era uma máquina política que gerava um sistema centralizado de prestações de serviços, atendendo diferentes tipos de clientelas eleitorais territorializadas, sendo os estratos populares urbanos, apesar de sua heterogeneidade e fragmentação, os que constituíam o cerne de seu suporte eleitoral.

Com o processo de liberalização política do regime ditatorial, a partir de 1978 , se produz uma reativação do associativismo político, notadamente no meio urbano, proliferando as associações de moradores. Isto tensionará as estruturas de representação controladas pelo governo estadual. A formação de uma Federação paralela à oficial, que reivindicará a autonomia do movimento, visando à conscientização das capas faveladas a partir de uma gramática de exigência de direitos e tendo como principal mecanismo de relação com as autoridades governamentais a pressão dada pela 
mobilização social, marcará uma ruptura com as lógicas chaguistas de organização política das camadas populares. Porém, isso não significará necessariamente a ausência definitiva desse tipo de lógica.

Uma pesquisa realizada no Espírito Santo chegará a conclusões similares (BANCK e DOIMO, 1989). Apesar dos Movimentos Urbanos, ligados à Igreja Católica e ao Partido dos Trabalhadores, terem desenvolvido uma estratégia que se opunha às lógicas clientelistas, estas não foram derrotadas; ao contrário, essas posições fortalecerem-se nas organizações locais em determinadas conjunturas. Mas elas não eram "velhas" forças destruindo o "novo": as relações clientelistas eram um elemento a mais da análise que teria que ser considerado. Por outra parte, o campo popular, apesar do predomínio petista, no caso estudado, transformou-se num campo de disputa das diferentes vertentes políticas de esquerda, fragmentando o potencial político do próprio movimento. A hegemonia do PT e os seus concorrentes de esquerda eram indicadores de que a questão da autonomia era relativa e não um absoluto inerente ao novo movimento.

Carlos Nelson Ferreira dos Santos (1984) é também um dos autores chaves do grupo do Rio de Janeiro. Sua visão, mesmo mantendo uma grande dose do ceticismo característico entre estes pesquisadores, será um pouco mais condescendente com o Movimento de Favelados do Rio de Janeiro. Porém, ele coincidirá com o diagnóstico de que o movimento foi dependente das flutuações políticas nacionais, que, no quesito específico das favelas, oscilou entre dois polos: a remoção e a urbanização; ou seja, entre o autoritarismo despótico e o autoritarismo demagógico. Nesse limitado e subordinado espaço de ação, o Movimento Favelado conseguiu, em algumas conjunturas, inclinar a balança a favor da urbanização, mas na visão do Estado: "Em ambos os casos, nunca se abre mão de qualquer parcela do processo de tomada de decisões. Bom ou mau, o pobre, morador de favelas, não é visto como alguém capaz de decidir sobre o que lhe diz respeito, sobre si mesmo. Precisa ser tute- 
lado. O que varia é o método; com violência ou com compreensão benevolente" (SANTOS, 1984, p. 33).

O autor reconhecerá que, entre 1962 e 1967, o movimento favelado logrou um extraordinário nível de organização e mobilização; porém, no contexto autoritário, o movimento foi esmagado. Não obstante, na sua ação mostraram que "as favelas são uma das muitas portas de entrada e de saída pelas quais, através de ações humildes, os pobres vão refazendo o que lhes dão como pronto e acabado. Aí, rejeitam umas tantas coisas, adotam outras, transformando o recebido e, com generosidade, devolvem-no à cidade" (SANTOS, 1984, p.40).

$\mathrm{Na}$ sua principal obra, Movimentos Urbanos no Rio de Janeiro, de 1981, o autor oferece uma visão contrária à interpretação dos MSUs baseada numa experiência etnográfica riquíssima, sustentada no seu trabalho como arquiteto da FAFEG, durante o processo de urbanização de Favelas cariocas. Para este autor, o conceito de MSU, ao sobredimensionar a novidade de uma nova forma de conflito social, termina por não distinguir capitalismo de cidade, convertendo a demanda dos pobres urbanos em reflexo da luta de classes e transformando sua análise numa moldura externa, comprometida e ideologizada que não é sensível à particularidade das experiências reais da luta urbana. Contrário a essa visão, Santos busca compreender os limites da ação urbana dos pobres da cidade, mas reconhecendo o potencial transformador de sua própria ação. Ele mostrará como nos casos de resistência bem-sucedida às tentativas de remoção, longe das expectativas de alguns militantes, a experiência não representou um protótipo do ideal esperado de uma urbanização socializante, pois observou uma regressão do pretenso sentimento de comunidade em direção a objetivos individualizados, e seus integrantes começaram a agir como qualquer outro proprietário. Detrás de um suposto interesse comum, na verdade estava presente uma porção determinante de interesses particularizados em jogo. 
Por outro lado, será Licia Valladares (2005) a autora que apresentará uma das tentativas mais elaboradas de posicionamento frente à tradição representada por Manuel Castells. Indo além das visões que identificavam na participação popular uma ação passiva ou que entendiam a relação dos favelados com as autoridades públicas como meramente hierárquicas, a autora negou a existência de um MSU à Castells, afirmando preferir como modelo explicativo uma teoria dos free-riders de inspiração olsoniana. A lógica da ação coletiva que está por trás desta reflexão considera que não necessariamente cidadãos que têm um interesse político comum se organizarão e lutarão em favor dele, já que não vale a pena sacrificar tempo e dinheiro para conseguir uma minúscula participação no ganho coletivo que consiga a ação, pois ele será distribuído mesmo entre os que não fizeram o sacrifício; assim sempre será melhor deixar que outros façam esse esforço (OLSON, 2001). Mais individual que coletiva e ideologicamente utilitária, desta maneira, a prática dos favelados se caracterizaria pela capacidade para ativar mecanismos, tais como o "jeitinho brasileiro", para obter benefícios por meios formais e informais.

Um excelente exemplo desta "desmistificação da participação popular" é a própria pesquisa de Valladares intitulada Passa-se uma Casa (1978b). Nesta obra, a autora realiza uma profunda análise do Programa de Remoção de Favelas do Rio de Janeiro, mostrando como a favela reagiu a um dos processos de renovação urbana mais importantes da cidade. A resposta dos favelados foi empregar a astúcia e determinação para criar alternativas e tirar o maior proveito possível do sistema: apareceram "favelados de última hora" (para aceder ao programa), declaram-se rendas maiores para obter melhores terrenos e casas, postergaram-se assinaturas, atrasaram-se pagamentos, parcelaram-se dívidas, ocuparam-se os imóveis sem pagar, venderam-se direitos, passaram-se casas. Todas essas práticas de distorção do sistema habitacional terminaram por provocar um resultado inverso ao que 
o programa aspirava chegar, sendo um propulsor das favelas, pois aumentou o número de favelados: boa parte dos beneficiários do programa terminou voltando a morar na favela, abandonando os conjuntos habitacionais criados. Portanto, a favela persistiu e se afirmou no espaço urbano. Um dado absolutamente relevante é que, na maioria dos casos de remoção analisados por Valladares neste período (1968-73), o despejo se realizou praticamente sem resistência dos moradores, sendo as próprias Associações de Moradores colaboradoras do processo (segundo a autora, para obter privilégios para seus membros). De fato, as derrotadas tentativas de resistência, como no caso do Pasmado e da Ilha das Dragas, são mobilizadas para concluir que "as favelas nunca chegaram a representar núcleos organizados de resistência e luta” (VALLADARES, 1978b, p. 52), pois os moradores teriam comprovado na prática as dificuldades de enfrentar coletivamente o plano governamental de remoção.

A questão é que a favela é uma área dependente, e como tal a mudança nacional produzida com a ditadura provocou transformações dentro da favela, particularmente nas relações com a política. Frente à atualização das políticas de remoções e as tentativas de controle por parte do Estado (Decreto n. 870 de 1967), as Associações de Moradores, já fracas antes disso, foram superadas pelos desafios do momento. Segundo a autora, tiveram que se adaptar à nova situação, particularmente depois da crise da FAFEG provocada pela remoção da Ilha de Dragas. Os moradores perceberam que não podiam fazer nada frente às remoções, pois as tentativas de resistência tinham se mostrado inúteis, e mesmo na alternativa de remoção existia a chance de obter benefícios. Com a ausência da tradicional relação entre político e cabo eleitoral, devido à eliminação das eleições, o papel do político foi substituído pelos integrantes dos escalões médios e baixos da burocracia governamental: 
Este 'novo' tipo de agente externo é que passou a pautar o tipo de relações que a favela e seus residentes mantêm com o 'mundo de fora'. Os moradores locais, seja das favelas, seja dos conjuntos, voltam-se agora para estes intermediários (do mesmo modo que se voltavam antes para os políticos e cabos eleitorais), a fim de obterem vantagens e favores pessoais, pois estes são os que têm hoje alguma coisa a oferecer. Da mesma forma que antes, esta população tenta extrair vantagens do sistema em vigor muito embora os agentes, os favores a ser obtidos e os elementos que possam ser manipulados sejam outros (VALLADARES, 1978a, p. 115).

Tal como explica Schmidt (1982), a ditadura militar desenvolveu uma política urbana caracterizada por uma extrema centralização do poder, própria de um contexto autoritário, dada também pela limitação da participação pública e o predomínio de orientações tecnocráticas que visavam à despolitização dos assuntos públicos. Ao mesmo tempo, a ditadura buscou uma fonte de legitimidade no apoio popular, mediante a criação de um organograma burocrático que investisse em infraestrutura urbana e para que lidasse com a questão habitacional sem renunciar à remoção das favelas como componente de sua política. Daí o papel do Banco Nacional da Habitação, do Sistema Federal de Habitação e de figuras de financiamento, tais como o Fundo de Garantia e a Caderneta de Poupança.

A divisão interna do trabalho no interior do aparelho estatal emergente se caracteriza por um deslocamento de poder dos corpos parlamentares para os centros burocráticos, fato que tende a reforçar a ascensão de ideologias, grupos e instituições tecnocráticas. Consequentemente, a política subordinou-se ao campo da administração pública e sujeitou-se a regras de racionalidade deri- 
vadas de sistemas finalistas, ao invés de se basear em mecanismos para a geração de consenso (SCHMIDT, 1982, p.13).

Desprovidos do voto, o que o favelado oferecia em troca de favores pessoais era a realização de serviços (como empregadas domésticas, pedreiros, eletricistas etc.). Atualiza-se assim a já conhecida lógica da manipulação dupla que anteriormente encontrou na relação político-favelado sua melhor expressão e que foi amplamente descrita pelos autores que desmitificaram a teoria da marginalidade no Rio de Janeiro. Esta lógica da “manipulação” da política seria uma manifestação do comportamento e da ideologia individualista que impera na sociedade brasileira. Valladares sustenta essa afirmação citando os estudos que compreenderam a questão social brasileira a partir de um olhar clientelista, onde as classes trabalhadoras aparecem como "massa de manobra". Resulta chamativo o fato de que a autora amalgame na sua interpretação da política na favela duas tradições até certo ponto contraditórias: a escola paulista de interpretação da questão social, que considerava a classe trabalhadora como massa de manobra passiva da política corporativista, e as leituras, que no Rio de Janeiro valorizaram a capacidade dos favelados para instrumentalizar a política como meio de obtenção de benefícios coletivos e individuais para a favela.

Ao estudar as associações voluntárias na Favela da Rocinha, Licia Valladares (1977) assinalará outros obstáculos para a mobilização política e social das favelas. Recolhendo um argumento de Carlos Alberto Medina (1969), a autora afirmará que as associações voluntárias, apesar de (e por serem) numerosas e variadas, possuem um efeito desmobilizador da população local, por compartimentá-la em torno de interesses diferentes. No campo das associações voluntárias, existiria uma luta por status social, pela capacidade das organizações de intermediarem a relação com o exterior da favela, uma vez que a maior parte das instituições locais são o resultado de iniciativas externas, representando uma ponte 
para maior valoração social. A participação nelas responderia a um interesse por alcançar posições de liderança frente aos seus iguais, por isso as organizações "inventariam” tantos cargos nominais.

As associações da favela que teoricamente deveriam unir seus moradores [...] têm produzido um efeito contrário. Na verdade estas organizações estão compartimentando a favela e reforçando o processo de diferenciação que se desenvolve entre os seus moradores. Elas vinculam seus membros ou entre si ou exclusivamente com os membros das mesmas instituições sediadas em outros locais. Não há consequentemente articulação entre as várias organizações face a objetivos que poderiam ser comuns à população (VALLADARES, 1977, p. 1402).

Resulta interessante constatar que o acentuado ceticismo da autora em relação ao potencial político dos movimentos favelados não é tão intenso em relação a outras manifestações como os Quebra-quebras, que no final da década de 1970 apareceram como uma onda de revoltas (VALLADARES, 1983). A autora mostrará que a ocorrência deste fenômeno não foi nem esporádica nem dispersa, mas obedeceu a uma cadeia de propagação em intervalos curtos, estabelecendo-se como um eficaz instrumento de pressão dos envolvidos (no caso estudado, operários da construção civil), e que existiu uma consciência da eficácia deste tipo de manifestação pública entre os mesmos, pois conseguiam ser ouvidos mais rapidamente. Porém, à diferença dos autores do grupo de São Paulo, ressaltará que o movimento não alcançou um caráter político mais amplo, nem houve participação de qualquer tipo do sindicato da categoria.

Para entender o quão provocadora foi a leitura utilitarista de Valladares, basta considerar que na visão do grupo de São Paulo a afirmação da própria identidade, apoiada nos valores de justiça e de solidariedade entre oprimidos, aparece como um valor 
por sobre qualquer cálculo racional para a obtenção de objetivos concretos (SADER, 2010). Porém, resulta pertinente fazer alguns questionamentos já neste ponto: ao afirmar a inexistência de uma ação coletiva organizada para evitar a remoção, exemplificando-o com as tentativas mal sucedidas da Federação de Associações de Moradores de Favelas do Estado da Guanabara (FAFEG) de confronto e oposição ao programa de remoção, se está confundindo a inexistência de um movimento com um que não deu certo. Aliás, com isso, demonstra, pelo contrário, que existiram resistências à ação do governo nesse tópico particular. Por outro lado, cabe a realização das seguintes perguntas: poderia a favela ter persistido e se afirmado no espaço urbano apenas mobilizando uma gramática particularista, baseada em uma ética individualista e utilitarista? Não existe acaso na demanda de "urbanização sim, remoção nunca" uma noção - embora dispersa - de luta pelo direito à cidade, sustentada na demanda por permanecer num espaço conquistado? É possível atribuir apenas uma motivação utilitarista à lógica do jogo político dos favelados?

Ao menos em relação a esta última pergunta é possível remeter-se novamente à liderança Benedito de Macedo, pois sua fala parece contradizer tanto o moralismo do grupo de São Paulo (o jogo é imoral para os novos movimentos) quanto a redução utilitarista feita por Valladares:

Ninguém está vendendo seu voto. O que está ocorrendo é que as comunidades de base carentes, as favelas, as associações, todas elas têm suas ideias. Ainda mais aqui no Rio de Janeiro, onde o Estado é permanente de oposição ao Governo Federal. Portanto, todos nós, líderes, temos a nossa ideologia.

Agora, a maioria dos presidentes está respondendo aos políticos com a mesma moeda. A bargalha é feita 'malandramente' e isto não quer dizer que uma determinada população ou liderança po- 
lítica, não tenha ideologia. Eles têm e todos estão ansiosos para que haja eleições porque nosso código é boca de urna. Nós dizemos sempre para os membros da comunidade: na boca de urna nós sabemos em quem votar. Nós temos nossa ideologia, nós queremos uma democracia, nos queremos realmente que a oposição ganhe, queremos tirar esse regime totalitário de 18 anos. Mas queremos como eles tiraram a liberdade do povo, na força. Nós queremos tirar na força do voto (PFEIFFER, 1983, p. 16).

\section{A critica teórica aos MSUs}

Luiz Antônio Machado e outros autores tentaram contribuir à superação do paradigma ou campo de estudos dos MSU, para o qual analisaram teoricamente sua consistência interna, suas fraquezas analíticas e as contrastaram com a evidência empírica disponível no Rio de Janeiro. Em uma série de trabalhos apresentados principalmente nas reuniões da ANPOCS do grupo "Lutas Urbanas, Estado e Cidadania”, foi elaborada uma crítica sistemática aos principais pressupostos e princípios dos MSUs, fundamentando parte importante da perspectiva alternativa resenhada anteriormente.

A principal crítica de Silva (1990, p. 8) será que inicialmente o paradigma dos MSUs estabeleceu uma "polarização dicotômica que enrijeceu o paradigma - 'cooptação' ou 'autonomia', concebidas como alternativas únicas e reciprocamente excludentes". Nesta polarização, o popular equivale ao espontâneo, autônomo e, como tal, é sempre virtuoso, enquanto o institucional/estatal é compreendido como o lugar da cooptação, repressão e dominação.

Todo o processo político é concebido como contendo dois campos em oposição: de um lado o 'movimento social', lugar da liberdade (ou da libertação), de afirmação da identidade e de controle 
sobre sua própria existência por parte dos grupos mobilizados; de outro, o 'sistema institucional', lugar da repressão, controle e dominação desses grupos. O processo político - a luta política, ou 'a política' tout court - é o conflito entre estes dois campos cujo resultado não é concebido como uma síntese que transforma ambos, mas como a diluição de um pela interferência vitoriosa do outro (ou o movimento social é engolfado pelo sistema institucional e desaparece nele, ou, ao contrário - e este é o fim almejado -, o sistema é destruído pelo movimento social) (SILVA e RIBEIRO, 1985, p. 327).

Flávio Cunha (1993), tomando como referência Machado, exemplificará a problemática autonomia/cooptação, mostrando o impasse produzido numa favela em Belo Horizonte com a implementação de um programa público de urbanização do assentamento (Prodecom). Esse programa estabeleceu um canal institucional relativamente estável de comunicação entre a população e o Estado, e tanto a população quanto uma parcela importante das lideranças agiram com uma visão pragmática ante o que entendiam como um programa benéfico para a comunidade. Atitude que encontrou a crítica dos "assessores" e analistas dos Movimentos Sociais Urbanos, por considerarem o programa como uma tentativa de controle estatal, que os distraía da luta principal (a regularização da terra e mudança radical da sociedade). As lideranças populares, porém, não pareciam considerar que sua autonomia dependesse da recusa sistemática ao diálogo e aos benefícios providos pelo poder público.

Não seria exagero afirmar que esse tipo de construção teórica acaba por contribuir para a produção da própria realidade no momento seguinte, na medida em que reforça e legitima ações dos novos grupos no poder. A visão quase mítica de um Estado permanentemente disposto a desenvolver mecanismos de cooptação 
e controle das expressões populares organizadas tem impedido essas análises de indagar, por exemplo, se os programas ditos participativos do fim do ciclo autoritário, como o Prodecom, não teriam, paradoxalmente, estabelecido bases mais democráticas de relacionamento com as organizações populares e apresentado resultados materiais superiores àqueles que os sucedem em plena fase de redemocratização do país (CUNHA, 1993, pp.141-2).

Este maniqueísmo analítico não apenas é limitado por esta polarização inicial, como é ela que antecipa as conclusões dos seus próprios estudos: o externo (cooptação e/ou esvaziamento) versus o interno (mobilização e/ou enfrentamento). Um movimento urbano organizado autonomamente é sempre vitorioso, mas um que se relaciona com o Estado está sempre derrotado. Ignora-se que o Estado foi, particularmente no Rio de Janeiro, muitas vezes o fomentador deste tipo de instâncias (Associações de Moradores) e omite-se o papel da Igreja (um agente externo) na conformação e sustento dos mesmos (SILVA e RIBEIRO, 1985). De um lado, se sobre-estimam e celebram as formas de organização espontâneas, como quebra-quebras, e, de outro, se minimizam as experiências de organização mais institucionalizadas. A rotinização da ação coletiva era vista como uma ameaça ao caráter inovador dos movimentos reivindicativos, rejeitadas como formas de cooptação institucional e interpretadas como desvios na prática política popular. Posteriormente, a rotinização será traduzida como um "refluxo" e como uma perda de relevância política.

Por exemplo, Lima (1989) reivindicará a existência de um Movimento Favelado mesmo antes da aparição da onda de mobilizações populares urbanas. Para ela, a formação da União de Trabalhadores Favelados (1954) já no nome indicava uma articulação entre o movimento sindical e a organização dos favelados, marcando-se, ademais, uma dimensão de identificação dos favelados enquanto trabalhadores (que não dispunham de outra forma de mo- 
radia). Neste texto, dar-se-á especial atenção à expressiva presença de lideranças sindicais no movimento de trabalhadores favelados, particularmente entre as categorias mais concentradas nas favelas: sindicato dos têxteis e o da construção civil, junto com a presença de militantes comunistas na organização do movimento.

Machado também marcará o fato das associações terem sido criadas pelo governo de Carlos Lacerda, como uma forma de suporte político de base popular, e, embora existissem mecanismos de controle formal (a aprovação dos estatutos das associações dependiam do Estado), as organizações conseguiram libertar-se da tutela do Estado para criar a FAFERJ e, em 1969, em pleno auge da repressão, organizar um Congresso extremamente progressista (apud PFEIFFER, 1983).

Porém, tal como assinala Ziccardi (1983), se os movimentos urbanos tiveram centralidade política nos anos 1960, foi porque, no contexto de aprofundamento dos processos democráticos dos países da América Latina, muitos dos governos progressistas buscaram na ampliação do espaço político das classes populares a principal fonte de sua legitimidade. Mas, apesar das favelas terem desenvolvido formas de organização cultural sem paralelo na América Latina - tais como a escola de samba (GOLDWASSER, 1975) -, bem como outras formas de organização religiosa (CEBs) e social (Associações de Moradores), elas não foram suficientes para gerar um processo mobilizador o bastante, a fim de frear o processo estatal de redefinição funcional do espaço que encontrou, na remoção forçada de populações faveladas, sua maior expressão. Estas organizações contribuíram sim a definir e reforçar a identidade coletiva da favela e sustentaram também, em parte, a oposição favelada aos processos de remoção. A experiência de remoção esteve longe de ser experimentada passivamente: as organizações faveladas opuseram um projeto de reforma urbana e agrária para resolver os problemas habitacionais do povo, e a demanda por "urbanização" das favelas foi a mais importante bandeira do movimento. Porém, 
a carência de uma estrutura organizativa anterior, apesar dos esforços da FAFEG, além do contexto autoritário, impediram que a favela cobrasse uma centralidade maior no contexto político carioca dos anos 1960 (ZICCARDI, 1983).

Para retomar a reflexão de Machado, vale fazer as seguintes perguntas: Quais são as consequências teóricas da perspectiva dos MSUs? Qual é sua relação com as teorias da questão social e da questão urbana no Brasil? Machado da Silva (1990, pp. 5-6) estabelecerá uma relação de continuidade/ruptura com a tradição teórica do campo dos movimentos sociais no Brasil, definida nos seguintes termos:

Este novo campo temático dava continuidade à conclusão da teoria do populismo, de que partidos e sindicatos estavam 'viciados', funcionando mais como instrumentos de dominação das massas do que como porta-vozes de suas demandas. Ao mesmo tempo, ele representava também uma profunda descontinuidade, na medida em que o paradigma dos movimentos sociais foi um corolário ativo e otimista desta conclusão: movimentos sociais em torno das carências de consumo coletivo representariam canais autônomos de gestação e vocalização daquelas demandas. Ele implicou também uma alteração fundamental da teoria da marginalidade, que a fez mesmo desparecer: onde se via lugares, como acima indicado, passa-se a ver atores e forças sociais. Isto levou a mudanças importantes de integração pelo estudo de processos específicos de trabalho e suas implicações para a formação de consciência e conformação de modos de vida.

Para Ana Clara Torres Ribeiro, a mobilização da sociedade tem uma influência na imposição de questões ao debate acadêmico, porém, o pensamento acadêmico repercute também nas conjunturas políticas. Por que se tornou quase "natural" a compreensão da 
mobilização urbana nos termos dos MSUs? Qual é o significado social deste fato? Existe um duplo movimento de caráter complementário, onde determinados fatos (invasões, mobilizações etc.) tonaram-se relevantes e um determinado marco interpretativo é escolhido para dar conta dos mesmos (RIBEIRO e LIMONAD, 1982). As autoras citadas anteriormente são cuidadosas e não pretendem negar a importância social destes movimentos, mas se interrogar pela forma como são incorporados teórica e empiricamente. Parece existir na construção do objeto científico uma preponderância das interferências de conjuntura por sobre as interferências de estrutura, adquirindo as reivindicações urbanas um caráter quase programático e normativo do futuro. A inclusão da problemática urbana como parte substantiva da conjuntura política tem consequências não apenas sobre o que se entende por novo, mas também sobre como se qualifica o velho. Por exemplo, o declínio do Estado populista a partir da mobilização popular. A ideia de MSU está carregada de conotações políticas e teóricas, o discurso teórico se entrelaça com o discurso político (RIBEIRO, 1982a). Os MSUs, portanto, são um desafio teórico e metodológico que põem em relevo o espaço metropolitano como categoria/objeto de estudo, legitimando a pesquisa urbana, no qual o saber urbano pode contribuir a densificar o significado político da metrópole. Embora manifeste sua insatisfação com a teoria dos MSUs, seu peso na conjuntura e nas ciências sociais abre o caminho para uma compreensão interdisciplinária não apenas da luta no espaço urbano, mas da luta pelo espaço urbano (RIBEIRO, 1982b).

\section{Movimentos Sociais Urbanos no Brasil, promessa descumprida?}

Boa parte da polêmica sobre o papel central que caberia às classes populares na democratização brasileira foi dirimida pelo tempo. Com o início da transição democrática, parte importante das expectativas criadas pela academia se diluíram, dando lugar a 
avaliações mais desiludidas, de uma maneira que até não surpreende se for considerado que em outras latitudes realizavam-se balanços similares. Por que movimentos que conseguiram importantes conquistas durante a ditadura, provocando efeitos urbanos e introduzindo uma cultura política democrática no universo popular, na conjuntura aberta pela transição não foram capazes de mostrar o mesmo vigor de antes?

O que é certo é que os movimentos de reivindicação não tiveram a capacidade de fazer valer, no nível de estruturação de instituições novas e de participação das já existentes, a conquista de 'direito' que chegaram a formar parte da cultura política do país. Em outras palavras, a mobilização popular conseguiu inscrever a questão social no centro dos valores políticos, o que levou a ação estatal, no caso do poder público, a uma intensa regulação institucional, a que não se contrapõe, em consequência, com o caráter de concentrar a riqueza e o poder do Estado. As classes populares compareceram através de uma 'negatividade ativa' que não tem a capacidade de contribuir à formulação de tais políticas. Não houve nenhuma reivindicação no sentido de gerar os canais promédios mediante os quais pudessem comparecer estas classes de maneira ativa no processo que lhe foi negado sistematicamente (NUNES, 1986, pp. 84-5).

Apesar das superexpectativas criadas pelas ciências sociais sobre o potencial democratizador e emancipatório dos movimentos sociais dos anos 1970 e 1980, foi indubitável para alguns autores, tal como assinala Vigevani (1989), que, no plano ideológico, a maior contribuição destes movimentos foi reinstalar no campo da política, mesmo que marginalmente, a questão da igualdade e dos direitos. Esses movimentos deixaram sua marca na Constituição e, indiretamente, no sistema político, na medida em que foram sustento da estratégia eleitoral do PT e de outras agrupações de 
esquerda. Além do mais, é preciso reconhecer que a presença desses movimentos desafiou a ditadura militar, pois sua existência era ilegal e cada uma de suas manifestações (reprimidas) contribuíam para a deslegitimação do regime autoritário (KOWARICK, 1987).

Porém, no exercício de compreensão desses movimentos, uma parte das ciências sociais, principalmente o grupo de São Paulo, minimizou o papel dos agentes externos e sobrevalorizou o caráter espontâneo da mobilização, estabelecendo uma tensão antagônica entre as manifestações populares e os processos de institucionalização do sistema político. Em contraste, outra parte da academia, o grupo do Rio de Janeiro, tendeu a subestimar o potencial político dos movimentos, ressaltando o caráter limitado e precário da sua ação política (JACOBI, 1987). Mas esta polêmica também permitiu a elaboração de sínteses que buscaram superar esta dualidade acadêmica para definir o campo popular:

Trata-se de um campo que, ancorado em instituições de porte como a Igreja Católica, o ecumenismo secular e entidades de cooperação internacional, não sem enraizamento na intelectualidade de grupos de esquerda, constituiu-se à base de extensas redes movimentalistas, predispostas ao incremento de ações-diretas de tipo reivindicativo. Portador de um repertório comum de linguagem, propagado e potencializado por dispositivos de certa 'pedagogia popular', tal como espalhou-se por todo o território nacional entre meados das décadas de 1970 e 1980, dando origem a um grande ciclo reivindicativo, movido por uma socialidade cambiante, que oscilou entre uma face expressivo-disruptiva e uma face integrativo-corporativa. E foi precisamente nas diversas combinações dos termos desta dupla face que as energias sociais e os recursos de poder então gerados foram ganhando expressão política, seja no que se refere à construção partidária e à criação de uma central de movimentos 
populares, seja no que concerne à institucionalização de novos direitos sociais e à interferência no sistema de representação de interesses pela via conselhista (DOIMO, 1995, p. 32).

Porém, quais foram as condições teóricas que fizeram possível esta polarização acadêmica? Para Ruth Cardoso (1987), os Movimentos Sociais da década de 1970 e 1980 são fruto de uma dupla conjuntura intelectual e política. Um dos supostos destes autores é que a ausência de participação popular na esfera pública brasileira é uma tradição, atribuindo aos novos movimentos sociais a capacidade de construir identidades políticas como novos atores e uma autonomia frente ao sistema político por meio da espontaneidade da sua agência. $\mathrm{O}$ fundamento da identidade é a experiência de vida comum num processo de funcionamento democrático dentro dos grupos que outorga autenticidade ao seu acionar. As consequências desta maneira de conceber os movimentos sociais são que esta substancializa a identidade do movimento, ignora as mudanças no próprio Estado (ao qualificá-lo como intrinsecamente antagônico aos movimentos) e identifica o discurso elaborado dos movimentos com a descrição de sua própria ação. Estaríamos frente a uma confusão entre observação participante e opção ideológica paralisadora da capacidade analítica dos intérpretes acadêmicos. Além de importar uma teoria, a dos MSUs, sem as devidas mediações, o que redundará na atribuição de um potencial revolucionário aos movimentos urbanos, como um substituto do proletariado. Agora, já que não se questiona o alcance político dos movimentos, a sua descontinuidade aparece como uma limitação a ser superada e não como um elemento integrante da dinâmica da mobilização social.

A atribuição de uma potencialidade emancipatória dos movimentos (revolucionária ou hiperdemocrática) seria mais a expressão de um desejo utópico dos analistas. "A negação da 'neutralidade' do pesquisador e o entusiasmo pela explicitação de seus 
compromissos com o grupo estudado não produziu uma crítica mais aprofundada sobre a natureza dos dados coletados nestas condições" (CARDOSO, 1987, p. 35). A participação nos movimentos é justificada por razões políticas e não pensada como instrumento do conhecimento, e a transformação do pesquisador numa espécie de porta-voz do movimento dificulta o necessário processo de estranhamento na realização da pesquisa.

Os novos movimentos sociais se instalam assim no ambiente acadêmico como uma retomada das faculdades políticas populares perdidas desde o Estado Novo. A cidade é vista como uma metáfora espacial da falta de representação pública do popular num contexto de cidadania regulada e restritiva, onde os trabalhadores são semipárias do sistema político e, ao mesmo tempo, ela é considerada como uma oportunidade de reversão deste processo que permitiu o desenvolvimento de um espaço público carente de presença popular (PAOLI, 1989).

Segundo a interpretação de Véra Telles (1987, p. 58, grifos nossos):

Essa 'descoberta' dos trabalhadores me parece ser o ponto central pelo qual se elaborou a certeza de uma novidade histórica nos movimentos populares recentes. E é uma 'descoberta' construída junto com (ou através da) a elaboração de uma nova percepção da assim chamada sociedade civil. Contra a imagem que nos foi legada pela tradição do pensamento político brasileiro que pontificava o seu amorfismo e dependência em relação ao Estado, a nova produção construía a imagem de uma sociedade cheia de virtualidades porque palco de práticas associativas e de luta e, sobretudo, porque lugar onde se dava a auto-organização dos trabalhadores, apesar das condições opressivas impostas e do fechamento de sindicatos e partidos como espaços possíveis para sua articulação. Em outras palavras, foi fora do Estado (e das instituições) e contra o Estado que esses autores perceberam a existência de uma classe 
atuante. Esse me parece ser o significado da ênfase tão grande dada às 'novas formas de participação' coladas no cotidiano da moradia. Não se tratava, portanto, de uma simples descrição muda de características objetivamente encontradas.

Daí a compreensão dos novos movimentos como sinais de um novo tempo onde talvez fosse possível a realização do que os trabalhadores se viram impossibilitados de concretizar. A novidade estava dada não por uma constatação empírica das práticas dos trabalhadores, mas nos significados que esses movimentos assumiram para o mundo da esquerda e para o campo intelectual. As leituras dos MSUs trazem as marcas do tempo de uma época na qual se buscava estabelecer uma ruptura com uma história passada. Existia, portanto, um duplo otimismo: o do intelecto e o da vontade.

Se hoje, munidos das questões que os anos 1980 propõem para a reflexão, podemos dizer com segurança que a novidade dos movimentos sociais em relação ao passado não pode ser reduzida à dicotomia cooptação-autonomia - que eles não são tão virtuosos como se acreditou, que as relações entre Estado e Sociedade são bem mais complexas do que os primeiros textos sugeriam e que é inviável postular a separação tal como foi posta por diversos autores -, nada disso porém desfaz aquilo que foi vivido e tomado como real. Esses movimentos populares foram muitas vezes pensados no interior de uma representação da sociedade como exterioridade frente ao Estado, como um contrapoder em gestação, como sinais de uma sociedade contra o Estado. Se foi assim que as coisas apareceram, então isso é algo que exige um deciframento. Pois nessa representação há algo mais que uma 'ilusão ótica' que, com o 'recurso da análise', poderíamos denunciar (TELLES, 1987, p. 75). 
Há no grupo de autores de São Paulo também um senso de urgência análogo ao que foi encontrado no grupo de Santiago que fundou a Escola dos MSUs. A questão não é a história do velho, mas o desborde do novo na cojuntura política, a aparição de atores, práticas e dinâmicas não reconhecidas anteriormente. As ciências sociais tornam-se uma ciência do presente peremptório e estão sempre correndo atrás de acontecimentos que desafiam sua compreensão. Parece preciso, nesse contexto, elaborar uma nova epistemologia sem perder o bonde histórico das mudanças sociais. Mas os pesquisadores podem influenciar nestes acontecimentos através da elaboração de construtos teóricos que clarifiquem cenários ou legitimem posições dentro dos próprios movimentos. Boa parte do otimismo destes autores se explica por este senso de urgência que os inclina a leituras ineditistas. $\mathrm{O}$ entusiasmo acadêmico não apenas respondia às possibilidades políticas abertas pelos novos movimentos sociais. Também a aparição de partidos de esquerda não leninistas, como o Partido dos Trabalhadores, representava uma esperançosa novidade para muitos destes autores, num contexto em que a Guerra Fria se aproximava de seu fim, pela implosão da União Soviética, e novas alternativas precisavam ser descobertas ou inventadas. As leituras ineditistas dos movimentos sociais foram, apesar do seu discurso autonomista, simbióticas com estas alternativas políticas em construção.

Quem não cumpriu sua promessa: o novo sujeito social urbano ou as teorias que tentaram descrever sua aparição? Sem dúvida, o movimento social existiu, criaram-se novas dinâmicas sociais, formaram-se novos quadros populares e fortalecerem-se projetos políticos a partir deste novo cenário. Porém, os novos movimentos sociais não fizeram a revolução, também não criaram uma nova democracia, mas deixaram sua marca na sociedade e na política do período.

Qual foi o papel da teoria social nesse fenômeno? Por um lado, as ciências sociais, mesmo que exagerando seu potencial, 
contribuíram para a legitimação destes movimentos, validaram-no teoricamente como ator e criaram uma conjuntura intelectualmente favorável ao reconhecimento destas manifestações como novas formas de protagonismo social. Porém, em que medida a sobre-estimação de sua promessa repercutiu negativamente nas avaliações que finalmente se consolidaram? Pelo menos, do ponto de vista acadêmico, a leitura ineditista gerou como reação imediata uma contraleitura que enfatizou as fraquezas e limitações destes movimentos sociais. Se as ciências sociais podem fazer da conversão de um movimento em desenvolvimento num ator que desafia a ordem estabelecida uma profecia que se cumpre por si própria, em que medida também a avaliação cética ou pessimista que se realiza a partir da superestimação acadêmica e não a partir das potencialidades reais de qualquer ator social não contribui para a perda desse protagonismo? 


\section{Capítulo 5 \\ Novidade E negação do Movimento de Pobladores na Ditadura Militar Chilena}

Com o golpe militar de 1973 que derrubou o governo do presidente Salvador Allende, terminou-se um processo ascendente de lutas populares que encontrou nos pobladores um dos atores principais. $\mathrm{O}$ que aconteceu com aquele movimento social que chegou a representar, para parte importante das ciências sociais, uma nova forma da luta de classes e um agente decisivo no processo revolucionário chileno?

Uma parcela significativa do aparelho repressivo da ditadura militar dedicou-se à desmontagem dos partidos populares e das organizações sociais que sustentaram as mudanças executadas no período anterior. Alguns dos principais dirigentes do Movimento de Pobladores foram presos, executados ou feitos desaparecer. Acompanhou esta política seletiva de repressão, uma série de ações coercitivas de caráter massivo contra os pobladores: invasões policiais, cercos de bairros populares, detenções massivas, sequestros, destruição e roubo de objetos pessoais e domésticos dos pobladores em cada intervenção repressiva (COMITÉ DE MEMORIA HISTÓRICA, 2005). Ante este cenário desolador, as ciências sociais se abriram a interpretações mais céticas que questionaram o potencial político dos pobladores. As seguintes palavras poderiam sintetizar de boa maneira o clima intelectual de começos da década de 1980 no Chile em relação a este ator popular: "Olhando o presente do setor, resulta difícil acreditar que mobilizações de tal 
magnitude tivessem lugar. As expectativas de uma reativação parecem se desmanchar frente à dura realidade do momento presente... Os pobladores parecem optar por soluções individuais" (ESPINOZA, 1982, p. 42).

Porém, com o primeiro protesto social convocado pela oposição, via um sindicato de mineração, em 1983, os atores populares entraram em cena novamente. A convocatória foi ampla e massiva. Participaram os sindicatos, a classe média, os estudantes, mas, para surpresa de muitos, o foco onde estas manifestações encontraram mais eco foi nos bairros populares, nas poblaciones. Com isso, o Movimiento de Pobladores recuperou protagonismo e as ciências sociais se reencontraram massivamente com este velho conhecido.

No 11 de maio de 1983 se realizou o Primeiro Protesto Nacional com ampla participação dos setores poblacionales. Nele explode a força contida por anos e se faz visível a capacidade de mobilização social urbana. Trata-se de um fato urbano de proporções, que modifica as condições gerais em que vive a sociedade. Até então, os pobladores organizados eram uma pequena minoria, enquanto a grande maioria se mantinha marginalizada. A rua volta a ser um lugar privilegiado de expressão dos conflitos sociais (VALDÉS, 1986, p. 299).

Embora houvesse estudos sistemáticos sobre as poblaciones chilenas desde finais da década de 1970, com a conjuntura aberta em 1983 pelos protestos, o interesse da academia pelos pobladores ganhava status estratégico. Não seria totalmente justo afirmar que as ciências sociais redescobriram o movimento de pobladores, pois, como dito, houve importantes pesquisas que se ocuparam de descrever a situação socioeconômica dos moradores de poblaciones, assim como de compreender as incipientes, mas significativas, organizações de sobrevivência sustentadas com auxílio mútuo que os setores populares estavam desenvolvendo, principalmente com 
incentivo da Igreja Católica, para enfrentar a crise econômica provocada pelo ajuste estrutural realizado pela ditadura para instalar o neoliberalismo no Chile (MARSHALL, 1982). Porém, a diferença foi que, com o protagonismo político recuperado pelos protestos, agora as ciências sociais se reencontravam com o movimento de pobladores para discutir e qualificar o possível papel que lhe caberia na eventual recuperação da democracia.

Assim, ante a recomposição do movimento deixada em evidência pelos protestos, os estudiosos da questão poblacional se debateram entre leituras ineditistas e negacionistas do Movimento de Pobladores, ou seja, interpretaram a ação coletiva dos pobladores como uma nova promessa potencialmente democratizadora ou, num tom mais cético, questionaram a capacidade dos pobladores de estabelecerem uma crítica global e articulada contra a ditadura, ou seja, duvidaram de sua capacidade de expressar um projeto político. O autor de referência de ambas as perspectivas foi Alain Touraine, e o ponto de início destes novos esforços analíticos foi o questionamento da anterior escola que hegemonizou a compreensão dos pobladores, a leitura dos Movimentos Sociais Urbanos. Segundo Touraine (1987, p. 219), “é falso - como se pensou nos anos 1960 - que existam movimentos urbanos de pobladores hiper-radicalizados. Este exército de reserva da revolução, em efeito, não se mobilizou nem no ano 64 no Brasil, nem no 66 ou 67 na Argentina, nem no ano 73 no Uruguai ou Chile".

Em relação às elaborações sobre o Movimento Favelado feitas no Brasil, existirá uma continuidade de tópicos: promessa democrática, autonomia, força da periferia, Educação Popular, cultura popular, democracia de base etc. Porém, uma grande diferença entre o Chile e o Brasil será que, neste último país, boa parte das discussões se realizarão a partir ou contra Manuel Castells, enquanto no Chile este autor perderá centralidade nas referências e será assumido como uma leitura superada. 
Por que Castells não é retomado nas discussões sobre o Movimento de Pobladores durante a ditadura chilena? O peso da sua análise sobre os pobladores durante a Unidade Popular é possível que tenha dificultado a recepção de suas reflexões posteriores, mais próximas das teorias da transição democrática com protagonismo popular, onde o potencial revolucionário está muito mais atenuado e matizado que no período de sua produção chilena. Depois de tudo, a existência da ditadura e a incapacidade do movimento popular para deter ou resistir ao Golpe de Estado representou uma prova empírica do exagero de algumas das principais teses de Castells. Porém, é possível que sua perda de influência obedeça também a uma estratégia de legitimação de uma leitura ineditista do Movimento de Pobladores, que exigia uma ruptura com a tradição intelectual pré-73. Por outro lado, o fato da própria teoria dos Movimentos Sociais Urbanos ter sido permeada crescentemente pela teoria dos Novos Movimentos Sociais de Touraine, contribuiu para ampliar a hegemonia quase monopólica, em termos teóricos, de Alain Touraine. Referindo-se precisamente a essa mudança na proposta de Castells, o autor de Palavra e Sangue afirmará que:

M. Castells - cujos importantes trabalhos foram com frequência invocados pelos defensores da tese da orientação revolucionária dos pobladores -, na realidade, sempre apresentou suas conclusões de forma mais prudente, observando que os movimentos só exerciam influência sobre as poblaciones se eram capazes de resolver os problemas quotidianos da comunidade e negociar com o Estado. Mas, além desta prudência, deve-se observar que as lutas dospobladores nunca são fortemente articuladas com lutas políticas, e M. Castells, mais recentemente, reconheceu, com uma admirável honestidade intelectual, os erros daqueles que acreditavam na capacidade revolucionária dos excluídos (TOURAINE, 1989, p. 272). 
A influência de Touraine marcou em boa medida o tom das interpretações que se desenvolveram na academia chilena durante a década de 1980, e foi a partir dos parámetros definidos na sua teoria que se definiu a condição ou inexistência do Movimento Social dos pobladores. Nesse marco, a renovação do campo de estudos do poblacional foi ampla e rica. Instituições como FLACSO, SUR, ECO, ILET e PET transformaram as poblaciones num locus prioritário do estudo do popular. A maior parte destas instituições possuíam um financiamento internacional, o que as protegeu das intervenções que a ditadura militar fez nas universidades chilenas. Muitos dos acadêmicos exonerados e perseguidos encontraram um refúgio intelectual nestes centros de pensamento independente. Isto permitiu uma produção acadêmica relativamente autônoma e, em certa medida, resguardada dos vaivéns políticos autoritários de uma ditadura que por esses anos empreendia o desmantelamento da institucionalidade acadêmica que outorgou ao Chile uma posição de liderança na produção de pensamento crítico na América Latina no passado.

Em traços muito gerais, o campo de estudos dos pobladores se dividiu em três grandes blocos interpretativos: a leitura comunitarista, a do antimovimento social e a espacialista. Todas elas destacaram a importância alcançada pelos pobladores no contexto ditatorial, porém a ponderação sobre as capacidades de sua ação coletiva para definir as condições de recuperação da democracia será o que as diferenciará. Poderia se afirmar que o principal (não o único) veículo de divulgação destas interpretações foi a revista Proposiciones de SUR, onde publicaram os resultados de pesquisa e seus artigos, os principais autores do campo dos estudos poblacionales. A revista Proposiciones preencheu o vazio deixado na área pela revista EURE, agora dependente do Instituto de Estudos Urbanos e Regionais da PUC-Chile, a qual redefiniu sua política editorial depois do Golpe de Estado (JAJAMOVICH, 2015). Particularmente exemplar, neste sentido, foi a polêmica ao interior de 
SUR entre o grupo de sociólogos que aplicou a teoria e os métodos de estudo de Touraine para analisar o movimento de pobladores (TIRONI et al., 1986) e o historiador Gabriel Salazar ([1990] 2006), pois esta controvérsia mostrará com mais claridade como a construção teórica do movimento de pobladores foi permeada pela conjuntura política da transição democrática.

Neste capítulo, serão revisitados os principais autores destas três grandes tendências, assim como as principais convergências e disputas deste reencontro das ciências sociais com o sujeito poblador.

\section{O Movimento de Pobladores como movimento comunitário}

O reencontro das ciências sociais chilenas com o Movimento de Pobladores está marcado pelo surgimento das leituras comunitaristas, ou seja, interpretações que destacavam a conformação de uma rede de relações sociais no interior das poblaciones sustentadas em valores, tais como: a solidariedade, a autoajuda e a organização. Esta reativação das solidariedades sociais no mundo popular é vista como potencialmente criadora de uma nova forma de fazer política. Sua novidade estaria dada pela capacidade de construir uma força autônoma da tutela dos partidos, pois as organizaçóes surgem ante o agravamento das condições econômicas da crise e do fechamento dos canais tradicionais de intermediação (no caso, os partidos). A leitura comunitarista valorizava também as experiências locais e as trajetórias biográficas dos seus protagonistas (QUINTANILLA, 1990). A recuperação da história local forma parte do esforço comunitário de construção de um "nós", (MOULIAN e DE WOLF, 1990; PAIVA, 1989) e a sistematização do saber e da experiência popular alimenta a noção do comunitário.

$\mathrm{O}$ que estava em curso, para estes novos intérpretes do poblacional, era "uma transição invisível” (GARRETÓN, 1987), ou seja, um fenômeno de redemocratização da sociedade através 
da reorganização dos sujeitos e atores sociais na base. O início dos protestos populares em 1983, com destacado protagonismo do mundo poblacional, determinou uma conjuntura onde a oposição parecia recuperar a iniciativa e onde se fortaleciam projetos políticos democratizadores sustentados na mobilização popular. A irrupção de uma força acumulada nas poblaciones visibilizou as organizações que estavam sendo criadas desde a década de 1970 para enfrentar a tarefa de sobrevivência econômica ante a instauração de um Estado antissocial que marginalizava um importante setor da sociedade. Principalmente articuladas em torno da Igreja, uma série de instituições de apoio vinham estimulando a organização popular desde o início da ditadura.

Os protestos populares de 1983 mudaram a conjuntura política e visibilizaram novamente os pobladores, porém a recomposição do tecido popular começou desde cedo. Sobretudo a Igreja Católica, já em 1973, iniciou o processo de estímulo da reorganização do mundo popular. Daniela Sánchez (1987) distinguirá três etapas da relação entre instituições externas e a ação poblacional entre 1973 e 1981. A primeira (1973-76), é um período de emergência frente ao Golpe dominado por uma dinâmica reativa e de denúncia, destacando-se as organizações de defesa dos direitos humanos. A Igreja funda o Comitê de Cooperação pela paz no Chile como uma resposta ante a repressão e ante as necessidades urgentes de assistência: fome, desemprego e saúde. A segunda etapa (1976-78), está marcada pela aplicação de um novo modelo de desenvolvimento por parte da ditadura: a implementação de uma política de choque neoliberal que atinge os pobladores, que recebem uma maior recepção, por parte das instituições externas, frente a suas problemáticas. Há um maior apoio à organização popular, observa-se o surgimento de um conjunto de iniciativas de subsistência e ajuda recíproca e de uma rede de organizações populares com apoio institucional externo: refeitórios populares, bolsas de desempregados, oficinas produtivas, centros de apoio escolar, 
bibliotecas e grupos juvenis, grupos de familiares de Detenidos Desaparecidos, comissões de moradia etc. Em 1976, a Igreja Católica cria a Vicaria da Solidaridade, organismo fundamental de defesa dos direitos humanos e de apoio ao mundo popular. O poblador é valorado pelas instituições eclesiais como sujeito, sendo outorgada importância ao seu testemunho e sua experiência transformada na principal forma de conhecimento frente à orfandade de análises das ciências sociais. A terceira etapa (1978-81) foi caracterizada pela resposta à institucionalização da ditadura e seu regime econômico, onde fenômenos como o desemprego adquiriram traços permanentes. Assim, aparecem novas dinâmicas organizativas: comitês de fornecimento, oficinas poblacionales, equipes de saúde, assim como organizações mais revindicativas (habitação), e até se produzem tentativas de tomadas de terrenos, que são fortemente reprimidas. Começam a aparecer mais instituições externas não confessionais, cuja ênfase está dada na capacitação de acordo às demandas das organizações populares, valora-se a pedagogia da ação, a educação e o desenvolvimento de capacidades próprias.

A proscrição da atividade política levou a que a Igreja Católica assumisse papéis e funções políticas de primeira linha (CANCINO, 1997), primeiro mediante a defesa dos Direitos Humanos, mas também servindo como uma espécie de "escudo protetor" do mundo poblacional e como principal fonte de apoio logístico e humano para a reconstrução do tecido social popular das poblaciones (OXHORN, 2004). A recomposição do Movimento de Pobladores durante a ditadura não teria sido possível sem o papel de uma série de sacerdotes e freiras operárias, assim como de ativistas e educadores populares ligados à Igreja que fizeram da opção preferencial pelos pobres a principal guia do seu evangelho (JORDÁ SUREDA, 2001; SANTAPAU, 2005; VEIT STRASSNER, 2006).

Segundo Pozo (1983), houve uma constelação de valores comuns ao conjunto de instituições voltadas para o mundo po- 
pular, que consideravam a ordem sociopolítica imperante como ruim, injusta, autoritária e opressora. Ao mesmo tempo, com esse ponto de partida, afirmava-se outra ordem: justa, democrática e boa. Nesse quadro, a pesquisa e trabalho nas poblaciones se tornava um gesto de esperança, uma tentativa de "buscar-entregar" sentido. Em outras palavras, nas instituições se afirmava a vontade de redemocratização da sociedade chilena, e trabalhava-se com pobladores, porque eram considerados como agentes de mudança social e da redemocratização desejada. Portanto, uma das características das leituras comunitaristas será seu otimismo sobre o papel que poderia hipoteticamente jogar o mundo popular no término da ditadura militar. Porém, com o fortalecimento da via negociadora de transição à democracia sobre a via mobilizante, após o fracasso de uma série de ações chaves para esta última (atentado a Pinochet, internação de armas, redução dos protestos), as leituras sobre o movimento de pobladores ficarão mais céticas, mesmo no interior das interpretações comunitaristas.

Nas suas versões mais otimistas, para alguns autores (KRIÉS, 1983), o movimento social na ditadura estabelecia uma nova relação com o mundo da política, abrindo novas possibilidades para um projeto socialista, uma vez que ele seria uma resposta da base. Um movimento molecular no qual o povo teve que aprender a confiar em suas próprias forças ante a ausência dos partidos populares, rejeitando as relações de dependência com os partidos, não tolerando manipulações ou organizações rígidas. Particularmente, o Movimento de Pobladores mostrava com sua prática a busca de um projeto histórico-social alternativo de caráter participativo e libertário, surgido das organizações e, a partir da base, sustentado em práticas democráticas e na valoração das relações interpessoais diretas, estabelecendo como objetivo também o desenvolvimento pessoal, a rotatividade de funções e a autonomia frente às instituições de apoio. Porém, a diminuição da influência dos trabalhadores sindicalizados e dos partidos de esquerda trazia também inter- 
rogantes sobre a construção de uma visão totalizadora do projeto alternativo para criar uma nova hegemonia social.

Estaríamos diante de um novo tipo de rebeldia, da expressão de um conflito social de nova espécie, onde os protagonistas não seriam apenas os operários, mas os marginalizados, e onde o palco já não seria a indústria, mas a rua e a población (BASTÍAS e BENAVIDES, 1986). Frente a uma nova modalidade de acumulação capitalista que não assegurava o mínimo de reprodução da mão de obra, os marginalizados respondiam com "rebeldia primitiva”, com brotos espontâneos de cólera. O pobre ficava sem mecanismos civilizados de inserção, tendo que apelar a atividades expropriativas para sua subsistência: saques, tomadas, conexão ilegal a serviços (eletricidade, água etc.). Também se desenvolvia uma economia popular de subsistência e se consolidavam mecanismos informais de inserção baseados na solidariedade individual e familiar típicos das classes populares. $\mathrm{O}$ viés negativo é também o aumento de fenômenos como a prostituição, o vício em drogas e a delinquência juvenil.

O ponto de partida destas interpretações será duplo. Por um lado, se realizou uma série de pesquisas para compreender, diagnosticar e quantificar o que se entendia como uma nova forma de pobreza, baseada na exclusão e marginalização de setores específicos da população que se concentravam nas poblaciones e campamentos, processo que seria o resultado do ajuste estrutural propiciado pelo regime através da aplicação das receitas neoliberais como novo modelo econômico. Por outro, realizavam-se estudos sistemáticos que examinavam as estratégias de sobrevivência dos setores populares para enfrentar os ajustes neoliberais que fizeram dos pobladores o setor mais atingido negativamente por essas medidas. Começam a ser estudadas as Organizações Econômicas Populares (OEP) como átomo base do novo movimento de pobladores e como eixo central das novas leituras sobre este ator social. 
A pesquisa da equipe de Razeto (1990) sobre as OEPs, publicada pela primeira vez em 1983, será pioneira nesse sentido.

A aplicação do modelo neoliberal teria introduzido novas dimensões ao debate da marginalidade, redefinindo o conteúdo de variáveis estruturais, particularmente na constituição dos mercados de trabalho que configuravam os setores urbano-marginais (MORALES, 1982). O processo de desindustrialização e tercerização da economia, promovida pela ditadura, teria alterado a estrutura do emprego, incrementando o subemprego e as taxas de desemprego. A criação de programas de emprego mínimo ou de emergência por parte do governo são um bom reflexo disso: neles os trabalhadores (a maior parte moradores de poblaciones) recebiam um salário menor que o mínimo legal para a realização de trabalhos nas municipalidades (limpezas de praças, manutenção de infraestrutura etc.). A instabilidade passou a ser um traço típico da estrutura de emprego, o que, adicionado à focalização das políticas públicas direcionadas à extrema pobreza, com forte ênfase assistencial, e à desarticulação das organizações sociais, configuraram um deterioramento sistemático e acelerado das condições de vida da população em geral: níveis de renda, consumo etc. Deterioramento que se acentuava entre os habitantes de campamentos e poblaciones populares. Os processos de radicação e erradicação de campamentos agravaram esta situação, pois a criação de zonas de pobreza urbana delimitadas deteriorava paulatinamente as comunas receptoras de pobres e desarticulava as redes locais dos pobladores. Seus lugares de moradia abrigavam uma população majoritariamente jovem com acesso deficiente ao mercado de trabalho, com grupos familiares com escassos direitos previdenciários e altos níveis de desempregos (maiores que a média nacional) e, pelo déficit habitacional, com uma população crescentemente allegada (agregada), ou seja, famílias que moram na casa de outra, compartilhando ou não a cozinha. A existência dos agregados virou um indicador a mais da situação de pobreza, pois contribuía à deterio- 
ração das condições físicas e sociais dos já precários assentamentos e, ao mesmo tempo, transformava-se na força motora de novas tomadas de terrenos (MORALES, 1983).

Nesta situação de condicionamento econômico marginalizante, o mundo popular se organiza com estratégias de sobrevivência e participação, na busca de soluções aos seus problemas imediatos. Excluídos do mercado, desarticuladas suas organizações e eliminados os canais tradicionais de reivindicação e demanda, os setores populares desenvolvem as Organizações Econômicas Populares (OEP) (RAZETO et al., 1990). As OEPs são organizações de subsistência centradas no econômico e buscam satisfazer necessidades básicas, através da coordenação de grupos pequenos que enfrentam problemas comuns e imediatos. As OEPs, portanto, eram uma estratégia de sobrevivência dos setores populares. Eram consideradas diferentes formas de associação para enfrentar o problema da subsistência ou a satisfação de necessidades que os setores populares constituíram, contando muitas vezes com apoio de uma instituição externa. A partir de uma atividade econômica (produção ou fornecimento de bens ou serviços) como objetivo principal, enfrentaram-se problemas econômicos imediatos, através da utilização dos escassos recursos obtidos pelos setores populares. A cultura organizacional estimulada pelas OEPs destacava valores coletivos: a autogestão, a solidariedade e a ajuda mútua; e consideravam-se a si próprias, às vezes, como alternativas de transformação socioeconômicas e político-cultural.

Em geral, eram iniciativas que se desenvolviam nos setores populares, especialmente nas poblaciones marginais das grandes cidades, constituindo experiências associativas de grupos de pessoas ou famílias, enquanto instâncias que originavam organizações (possuíam objetivos, estrutura e procedimentos). Sua função era enfrentar coletivamente carências e necessidades concretas: alimentação, moradia, trabalho, saúde, ingressos, poupança etc. Portanto, eram organizações econômicas baseadas no próprio esforço 
e na busca de soluções imediatas, por meio da autoajuda e do desenvolvimento de capacidades próprias. Constituíam iniciativas que implicavam relações e valores solidários próprios do modo como se buscava satisfazer as necessidades do grupo: eram organizações que aspiravam a ser participativas, democráticas, autogeridas e autônomas. Essas organizações tendiam a ser integrais, não se limitavam a um tipo de atividade, havendo também ação política e pastoral. Elas propunham, na prática, alternativas solidárias e coletivas ao sistema imperante (capitalista, individualista, consumista e autoritário). Embora nascidas nos setores populares, contavam com o apoio das atividades de promoção de organismos externos: organizações religiosas ou ONGs interessadas no desenvolvimento local, espiritual e humano dos setores populares.

Existiram cinco tipos de OEP: 1) as oficinas produtoras de bens ou serviços (ou mistos); 2) as organizações de desempregados: bolsa de desempregados, sindicatos de trabalhadores eventuais, comitês de desempregados; 3) as organizações para o consumo básico: refeitórios infantis, refeitórios populares, "panelas comuns", comitês de abastecimento, "comprando juntos", bodegas populares de alimentos, hortas, grupos de autoajuda; 4) as organizações de problemas habitacionais: comitês de moradia, comitês de pobladores sem casa, grupos pré-cooperativos, comitês de serviços (água, luz, prestações da casa); 5) outras organizações poblacionales de serviços: educação, saúde, recreação, cultura, mulheres, aposentados, jovens etc. A equipe de Razeto cadastrou 494 OEPs em Santiago, em 1982, 702, em 1984, e 1.103, em 1985. $\mathrm{E}$, independentemente do peso quantitativo, destacaram que este processo organizativo poderia significar um germe de uma nova estrutura de ação popular transformadora, com capacidade de projeção com autonomia. As OEPs contribuiriam à construção da democracia desde baixo: eram ideias democráticas, comportamentos democráticos e organizações democráticas arraigadas na vida cotidiana do povo. Ainda mais se se considerava a relação 
entre organizações populares e desenvolvimento local (VAN HEMELRYCK et al., 1987). Não obstante suas limitações, as OEPs possuíam as condições elementares para a elaboração e a formação de uma nova forma de entendimento da participação, baseada nos princípios de localidade, pois tinham funções residenciais, laborais e administrativas-políticas. O local virava um centro de poder, o que, adicionado ao processo de municipalização, impulsionado pelo Estado, transformava o território num espaço disputável, onde potencialmente as organizações poderiam cumprir um papel central, e o local teria a possibilidade de se inserir num debate mais amplo de concepção do Estado.

A concepção desenvolvida a partir da OEP supunha a existência de uma economia subterrânea, submersa, oculta, invisível e paralela, constituída por uma série de atividades que a economia clássica não podia quantificar, pois não eram declaradas ( $\mathrm{SCH}$ KOLNIK e TEITELBOIM, 1988). A economia de subsistência utilizava recursos invisíveis e reservas que vêm da própria atividade social que permitiam atenuar os custos da aplicação de um modelo neoliberal radical. Desenvolveu-se uma economia de subsistência paralela para enfrentar os efeitos da crise: trabalho informal, OEPs, organizações locais para o consumo, produção doméstica de bens e serviços de autoconsumo, doações, empréstimos, permutas entre familiares e vizinhos, condutas desviantes (roubos, prostituição, assaltos) etc.

Para explicar a sobrevivência popular, é necessário apelar a outro tipo de realidades, tais como o apoio familiar, as doações e presentes, os canais de ajuda vicinal, a readequação da vida doméstica em condições de desemprego do chefe de família, a solidariedade de instituições não governamentais, o aporte de crianças e jovens ao sustento familiar, o recrudescimento da mendicidade, o roubo, etc. (SCHKOLNIK e TEITELBOIM, 1988, p. 22). 
A questão é, para essas autoras, a compreensão das estratégias de sobrevivência popular, ou seja, aquelas práticas destinadas a melhorar ou superar condições de carência extrema na qual vivia um setor importante da população, num contexto de pobreza heterogênea (há uma nova pobreza), onde o único comum é a expulsão do aparelho produtivo.

Uma das referências mais notáveis destas leituras foram as pesquisas realizadas por Larissa Lomnitz (1983) sobre barriadas na Cidade do México, que originalmente foram publicadas em 1975. A antropóloga chilena vai se perguntar: como sobrevivem os marginalizados? Ela mostrará que é a reciprocidade o que assegura a sobrevivência nos ambientes de marginalidade. São a redes de intercâmbio de ajuda mútua (entre parentes e vizinhos), baseadas na reciprocidade, que constituem o mecanismo socioeconômico que substitui a falta de segurança social destas populações. A segurança vem das relações sociais (um dos poucos recursos que possui o marginalizado), onde o que importa é a confiança, a proximidade física e os vínculos afetivos. Estas redes de assistência mútua conformam um sistema econômico informal e paralelo à economia de mercado, baseado no aproveitamento dos recursos sociais, que opera sobre o intercâmbio recíproco entre iguais.

Ao chegar à cidade, os migrantes não encontram lugar no sistema laboral industrial e viram marginalizados. Porém, o subsistema não rejeita totalmente os migrantes, mas somente nega o acesso às fontes de trabalho incorporadas ao sistema econômico industrial. Os migrantes rurais sobrevivem, se multiplicam e seus bairros proliferam em torno às grandes metrópoles da América Latina, o qual significa que os marginalizados encontram um novo nicho ecológico em simbiose com o meio urbano. Para se sobrepor à insegurança inerente a este nicho, os marginalizados geram uma organização social evolutiva característica (as redes de intercâmbio) (LOMNITZ, 1983, p. 30). 
A visão da autora permitiu renovar a discussão sobre marginalidade, tópico retomado pelos autores chilenos para compreender as consequências perversas do ajuste estrutural do modelo econômico durante a ditadura. Porém, o seu ponto de vista não é precisamente comunitarista. A barriada não é uma comunidade, mas um conglomerado de redes de intercâmbio recíproco, produto da falta de integração ao sistema econômico urbano-industrial. O bairro não é uma unidade social, mas geográfica. Porém, sua discussão vai ser incorporada nos debates chilenos como um complemento do desenvolvimento das OEPs, mantendo a ênfase na capacidade para responder e contestar as situações de marginalidade.

A ação dos pobladores teria transformado domínios da vida social, tradicionalmente considerados como privados, em objetos de definição de posições políticas, sendo incorporados ao debate público (VALDÉS e WEINSTEIN, 1989). Os pobladores introduziram novas formas de fazer política, ampliando a definição deste conceito. A exclusão social teve, como efeito inesperado, o fortalecimento dos laços internos dos pobladores, porém isso não teria se expressado numa melhor formulação de demandas frente ao Estado. Embora não expressem um projeto de mudança de sociedade muito claro, os pobladores teriam criado uma realidade dinâmica que anunciava transformações na sociedade, uma sociedade democrática por construir.

A recomposição do tecido de organizações de base é a forma que assume a resposta dos pobladores à ditadura, tendo como antecedentes os seguintes elementos: a experiência de participação acumulada no período anterior à ditadura, o deterioramento das suas condições de vida, o fechamento dos canais de demanda e benefícios sociais, o desemprego de trabalhadores com trajetória sindical, o desenvolvimento de uma rede de instituições de apoio ao setor poblacional e a formação de um significativo contingente de "educadores populares”. Para Valdés (1986), o momento de ascensão e consolidação do novo ator poblacional (81-84) coincide com um 
aumento da ação revindicativa e com a reconstituição do tecido social para satisfazer as necessidades imediatas da população.

A visibilização dos pobladores com os protestos associou externamente sua imagem com a ruptura da ordem e a violência, mas isso encobria a capacidade cotidiana da gestão popular iniciada desde cedo através das OEPs (HARDY, 1987). Essas organizações eram uma resposta popular à nova pobreza produzida pelo regime, a qual assume a forma de exclusão social com dimensões múltiplas de carência. A pobreza muda, mas também o fazem as percepções e os modos de viver a pobreza (práticas sociais). Frente à territorialização da pobreza, homogeneização das condições de pobreza num habitat deteriorado (segregação) e polarização da cidade (erradicações), territorializam-se também as estratégias de sobrevivência e surgem estratégias coletivas de subsistência com base territorial, com uma lógica que as autonomiza das lógicas familiares de sobrevivência típicas do mundo popular.

Essas novas organizações complementam e convivem com as tradicionais redes de vizinhos e de parentesco baseadas em trocas (LOMNITZ, 1983). Mas, para Hardy, se essas estratégias clássicas são defensivas e representam uma reação adaptativa a condições externas sem pretensão de questionamento da realidade, as novas organizações são propositivas, pois valoram a organização, a participação e a apropriação das condições de existência com certa visão de futuro.

Estas estratégias organizadas de subsistência são núcleos de relações sociais fora do espaço privado doméstico-familiar e que socializam problemas e necessidades individuais, lhes outorgando presença coletiva. É assim que, através destas novas práticas associativas, as necessidades básicas familiares (vividas e percebidas como problemas individuais e de resolução privada), adquirem o caráter de necessidades sociais, abordáveis, então, por comportomanentos sociais de orientação coletiva (HARDY, 1987, p. 38). 
Estas organizações mobilizavam setores que tradicionalmente não eram estimulados (os setores mais pobres e as mulheres), e seu fundamento era a necessidade, ou seja, as exigências da reprodução física e material dos lares populares. Elas estavam praticamente obrigadas a "funcionar", pois delas dependia a satisfação de boa parte das necessidades vitais dos seus membros. As OEPs, por serem desenvolvidas num espaço específico - a población -, também contribuíam a criar territorialidade, a estabelecer redes e conexões horizontais, substituindo as antigas organizações mais hierárquicas, apesar da dependência de apoios externos, além de empoderar as mulheres, que possuíam uma presença majoritária nelas. As OEPs eram, assim, espaços de práticas e exercícios democráticos.

Sem pretender lhes atribuir representatividade nem lhes outorgar virtudes éticas, sem a intenção de lhes assignar um papel de mobilização social ampla nem de supor um lugar central nas respostas econômicas dos setores populares, os grupos de subsistência ativos na atualidade constituem parte de uma realidade que oferece lições para o porvir de uma sociedade democrática que terá de ser, se efetivamente pretende alterar as atuais condições de iniquidade, necessariamente participativa (HARDY, 1987, pp. 220-1).

Porém, as OEPs também apresentavam limitações. Elas cultivavam uma concepção da ajuda como uma opção excludente à reivindicação, tanto quanto uma autoexclusão frente ao Estado, pela sustentação de uma noção de autonomia que opunha Estado e sociedade. Eram iniciativas que não conseguiam transcender o estreito âmbito das necessidades imediatas nem o limitado espaço no qual funcionavam cotidianamente. Por outra parte, o peso dos apoios solidários externos deixava dúvidas sobre a real autonomia do funcionamento dessas organizações. Além do mais, elas possuíam uma baixa projeção quantitativa dentro do mundo popular. Todos esses elementos levaram Hardy a questionar em que 
medida as OEPs poderiam atualizar seu potencial propositivo se continuavam sujeitas ao estreito mundo das necessidades imediatas do espaço local.

Dentro das OEPs, a Olla Común (Panela Comum) foi uma das instâncias mais estudadas pelos pesquisadores chilenos. $\mathrm{Na}$ prática e nas interpretações, a Panela Comum foi tratada como uma organização exemplar. Ela foi uma organização popular urbana para enfrentar diretamente o problema da fome, representando, para alguns autores (GALLARDO, 1985), uma prática popular coletiva peculiar e inédita. Frente à situação de desemprego, à crise da agricultura, à aplicação do livre mercado e à diminuição do gasto social, os pobladores se veem forçados a assumir a responsabilidade de garantir a vida das suas famílias e a compreender o caráter social da fome como produto da aplicação das políticas neoliberais. Alguns fenômenos naturais, como as grandes chuvas de 1982 e o terremoto de 1985, estimularam o surgimento destas panelas como resposta inicialmente de emergência. Mas o que se considerou transitório começou a virar permanente, e a panela comum deixou de ser uma alternativa frente aos desastres ecológicos para ser uma via prioritária para enfrentar as consequências de um modelo econômico excludente. A fome deixa de ser uma "culpa" individual por não conseguir alimentar a família; logo, é preciso o apoio e a solidariedade dos outros para encarar um problema que é comum. Começar a cozinhar juntos já é um grande passo, embora se mantenha a tradição de cada família comer na sua própria casa: "as panelas comuns são valoradas porque permitem atenuar a fome das famílias, mas tendem a ser consideradas como uma alternativa 'anormal', num duplo sentido: porque são sinônimos de uma situação de fome e miséria e porque tiram do interior das famílias em particular a tarefa da alimentação" (GALLARDO, 1987, p. 191). Porém, as panelas comuns possibilitam a constituição de uma consciência de exclusão política e social e geram outro tipo de transformação cultural: em relação ao papel tradicional atribuído 
à mulher popular destinada ao âmbito privado. As panelas comuns poderiam eventualmente contribuir à conciliação do social e do político e à formação de um sujeito popular fundamental para o projeto de transição.

Surgidas durante o atual regime e no contexto da crise econômica, as panelas comuns, enquanto crítica à definição privada do problema da fome, adquirem uma importância que não é conjuntural. Em efeito, se consolidada sua atual orientação e prática, contribuirão de maneira importante a facilitar a difícil articulação da luta social e política ao fortalecer o sujeito popular capaz de pôr suas próprias demandas e anelos na cena nacional (GALLARDO, 1987, p. 200).

Clarisa Hardy (1986) desenvolverá uma interpretação similar em relação às panelas comuns. Elas são organizações que agrupam um número variável de famílias numa mesma área (caráter territorial) que, pelos baixos ou irregulares ingressos, decidem colaborar com recursos, principalmente trabalho, para cozinhar em conjunto para satisfazer parcialmente suas necessidades alimentícias. Os participantes estabelecem relações regulares, objetivos explícitos e normas claras, além de se identificarem como iguais frente a uma necessidade e na busca de soluções coletivas. A panela comum promove o desenvolvimento de novas condutas: atitudes solidárias, sentido de reciprocidade, trabalho grupal.

A incorporação e o trabalho nas panelas comuns mostram que, junto à necessidade de comer, há também outras necessidades igualmente vitais. Necessidades de convivência, sociabilidade, participação e apropriação das próprias condições de vida, emergem diariamente nas práticas dos membros das panelas (certamente, não em todos eles, mas sim nos que permanecem e colaboram mais ativamente) (HARDY, 1986). 
As consequências das panelas comuns se observam mais no desenvolvimento pessoal e humano que no plano da alimentação propriamente tal, pela experiência de organização que implica. Até o participante menos consciente deve superar o medo à organização e a vergonha da fome para posteriormente compreender que a fome não é um problema individual.

A panela comum, para a autora, era uma prática anteriormente existente no repertório popular, que se realizava nas greves dos sindicatos e nas tomadas de terrenos, porém na ditadura foi readaptada como organização popular de consumo, o que lhe outorga sua condição de novidade. As panelas comuns mostravam a capacidade do povo para solucionar de fato suas necessidades, e, junto com a vontade de exigir direitos, vinculavam, na prática, as necessidades básicas e a democracia. Representavam também um espaço para aprender e exercitar normas de convivência democráticas, em face da ausência de formas institucionalizadas de exercício democrático. Essas organizações eram uma escola da democracia, ao mostrarem a capacidade da comunidade organizada para otimizar a distribuição de recursos. "A panela comum, na medida em que permite romper estas barreiras da fome, está começando a contribuir com um mundo desejável de liberdades. Por isso, ninguém aspira à continuidade das panelas, mas sim à permanência das relações que a fizeram possível: a organização popular como veículo de exercício democrático" (HARDY, 1986, p. 216).

Outro mérito das organizações populares desenvolvidas na década de 1980, em geral, e da Panela Comum, em particular, foi que questionavam os espaços que a cultura dominante outorgava à mulher: mãe, esposa e dona de casa (VALDÉS, 1987). A situação econômico-social em que viviam as mulheres bloqueavam as possibilidades de realização destes projetos pré-definidos. $\mathrm{O}$ déficit habitacional, por exemplo, impedia que a mulher virasse dona de casa. Sua participação, por outro lado, se dava através dos comitês de moradia ou tomadas de terreno, bem como de outras organi- 
zações de subsistência, o que representava uma saída da mulher para o âmbito público, contradizendo o papel pré-definido, para ela, de confinamento ao âmbito privado. No meio da crise econômica, a mulher pobladora virava o sustento moral e material do grupo familiar. Sua condição de mãe a obrigava a romper com as normas que o próprio sistema criava, fazendo das mulheres as primeiras a vencer o medo e se organizar. Nesse percurso de busca de respostas coletivas, as mulheres tomam consciência de uma dupla opressão: política e de gênero. Muitas organizações de subsistência derivaram em organizações de gênero. Estas são o primeiro passo para sair do limitado espaço doméstico, pois “tiram as mulheres de casa" (VALDÉS et al., 1988). Assim, a proposta cultural dominante se vê tensionada pela incapacidade de dar soluções concretas aos problemas que as mulheres devem enfrentar de acordo aos ditados da cultura hegemônica, uma vez que as condições de opressão da mulher se mantêm. Em muitos casos, a participação em organizações sociais deve passar pela aprovação do marido, e muitas vezes a participação se expressa em lugares que asseguram uma continuidade da ideia de esposa fiel e mulher decente, daí que a participação com maior legitimidade social seja quando se dá na Igreja.

Outro tipo de organização que vai concentrar atenção privilegiada dos pesquisadores são as Organizações Populares de Moradia (SCHERMAN, 1990), espécie de motor histórico do Movimento de Pobladores. Scherman distinguirá dois tipos de organizações: as reivindicativas, nas que se incluiriam os devedores habitacionais (hipotecários e de serviços) e os Comitês de Agregados ou Sem Casa; e as de Autoajuda, incluindo os Comitês de Autoconstrução e Reconstrução (por causa de desastres naturais), os Grupos de Poupança e os Comitês de Adelanto. O surgimento e desenvolvimento dessas organizações teria se visto facilitado pela conjuntura dada pelas mobilizações de 1983-85 e pelo terremoto de 1985, o que teria aumentado a legitimidade de suas demandas. Aliás, em 1983 reaparecerá como estratégia exito- 
sa de moradia a tomada de terrenos com os Campamentos Fresno e Silva Henríquez, os que se transformaram rapidamente em tomadas emblemáticas. Anteriormente se ensaiaram uma dezena de tentativas de tomadas, todas duramente reprimidas e abortadas. Esta conjuntura abriu novas possibilidades de relação com a institucionalidade e melhorou as possibilidades de levantamento de demandas reivindicativas por parte dos pobladores.

Ainda quando se apresentam exceções, comprovamos que, em geral, entre as lideranças das OPV está muito presente a noção de que na atualidade se devem estabelecer relações e negociações com o Estado, apesar de que este seja visualizado como antagônico, e a política econômica impulsionada pelo regime militar como a principal causa dos problemas que atingem a maior parte da população. Esta relação com o aparelho público é vista claramente como confrontacional, mas também existe a certeza de que é ineludível (SCHERMAN, 1990, p. 168).

A preocupação dos pesquisadores com a capacidade do movimento de pobladores de traduzir o desenvolvimento comunitário em estratégias reivindicativas eficientes e com a elaboração de um projeto político mais representativo os levará a estudar os esforços de coordenação metropolitana. Porém, apesar da importância que atribuíam a este tipo de instâncias, começarão a preponderar leituras mais pessimistas sobre o potencial político dos pobladores, sendo as Coordenadoras Metropolitanas as principais evidências das limitações de sua ação.

Embora existissem esforços desde 1977 (via Igreja Católica) para gerar instâncias de coordenação metropolitana dos pobladores, foi com o início dos protestos, em 1983, que apareceram as Coordenadoras, cada uma associada a uma tendência da oposição (comunista, democrata-cristã, esquerda cristã e esquerda revolucionária). A tendência a criar Coordenadoras foi lida por Valdés 
e Weinstein (1989) como uma herança do antigo movimento popular pré-ditadura, mas ao mesmo tempo como uma criação do saber-fazer do movimento popular sob a ditadura.

Com diferentes modalidades, a rede de organizaçóes populares forma parte do processo de ativação da vida poblacional, e os protestos, além da sua possível eficácia política, têm um efeito importante nelas. Constituem o impulso mais importante para o desenvolvimento de coordenadoras intermediárias, zonais, ou territorias de organizações de pobladores. Encontram-se múltiplas organizações, transcendendo os níveis alcançados até então. Surgem, sobretudo, como estruturas definidas pela luta contra o regime militar. Isto as coloca numa permanente tensão com aquelas organizações opositoras, e tendo emergido desde o campo das demandas sociais, tendem a manter sua ação principal nessa esfera. Entretanto, no nível local se produzem experiências importantes de unidade social com ações reivindicativas frente ao município (POJH [emprego de emergência], saúde, também convênios de pagamento de luz e água). (VALDÉS et al., 1988, p. 7).

Embora o estímulo de instâncias de coordenação fosse promovido por partidos e pela Igreja, o processo não era nada harmônico nem linear, uma vez que elas reproduziam e amplificavam as tensões entre o social e o político, ainda mais depois da crise de condução da oposição, quando a quebra entre a tendência institucional (Aliança Democrática - DC) e a rupturista (Movimento Democrático Popular - PC) se fez mais evidente depois do fracasso do atentado a Pinochet e da internação de armas por parte do braço armado do PC (o Frente Patriótico Manuel Rodríguez). Mesmo assim, Valdés e Weinstein atribuíram às coordenadoras um papel fundamental nas projeções do movimento, apesar da sua vulnerabilidade interna e da dependência externa aos partidos. 
Hernán Pozo (1987), já imbuído deste espírito mais cético, definiu o poblador como um ser que vive acossado pela insatisfação das necessidades mais elementares, e que boa parte do seu tempo estava dedicado a atividades que permitissem sua sobrevivência. Os pobladores são, na época, o setor social mais atingido pelo déficit de habitação, pelos índices de desemprego (30\% em 1982-83) e em geral pelos custos da crise econômica. Os pobladores são um conjunto de trabalhadores mal remunerados, desempregados ou subempregados que habitam a periferia de Santiago ou seus setores mais deteriorados, carecendo dos serviços mais elementares. A escassez e a fome adquiriam condição de problema político, enquanto a ditadura os definia como "excedentários" (sobram), marginando-os do acesso a uma série de elementos mínimos de sobrevivência e, além do mais, definindo-os politicamente como inimigos. São "objetos" perigosos e eventualmente manipuláveis. Daí as tentativas de relocalização socioespacial da pobreza feitas pela ditadura (MORALES e ROJAS, 1987), por meio da transferência massiva de moradores de campamentos para novos espaços dentro da cidade, provocando uma diferenciação entre comunas ricas e pobres, além de aumentar a polarização urbana, a marginalização e homogeneização social. Consolida-se a imagem de uma cidade dividida, caracterizada por uma distribuição espacial desigual dos acessos aos benefícios sociais, na medida em que a pobreza tende a se localizar em áreas residenciais específicas da cidade, frente ao que os setores populares reagem com organização e respostas coletivas aos seus problemas (HARDY, 1989).

O poblador é alguém que atua e coloca a población em movimento, mas o desenvolvimento de práticas coletivas o transforma em inimigo real do regime. Embora este os defina como manipuláveis, os pobladores viram atores, agentes das possíveis mudanças (POZO, 1987). Já em 1973, principalmente a Igreja Católica contribui à organização dos setores populares frente a uma situação que se considerava transitória, porém que dava sinais de institucio- 
nalização, aumentando as exigências organizativas. Essas organizações constituíam instâncias de participação inéditas, à margem do aparelho estatal e dos partidos políticos e onde novos atores, como as mulheres, adquiriam protagonismo. Porém, essas organizações possuíam um nível de heterogeneidade que atualizava o perigo de atomização, além de serem instáveis no tempo e carentes de recursos humanos e materiais suficientes. Por outra parte, os esforços de coordenação metropolitana não eram satisfatórios para lidar com a separação do social e do político. A questão era que não existia uma real consciência coletiva entre os pobladores, mas uma consciência individual comprometida na ação (tomada de terrenos, protestos, panelas comuns etc.). Assim, para o autor, "há movimentos poblacionales, lutas organizadas que protagonizam os pobladores. Estimamos, em contraste, que não existe um movimento poblacional propriamente tal. Os movimentos que se observam representam os pobladores marginais urbanos que reivindicam o reconhecimento de direitos essenciais e a satisfação de necessidades urgentes e impostergáveis" (POZO, 1987, p. 67). Ainda que ele não reconheça um movimento propriamente tal, aceita que a situação e ação dos pobladores deslegitimam o regime, pois evidenciavam a profunda injustiça que ele promovia. Aliás, qualquer projeto político que buscasse superar a situação desse momento teria que considerar os pobladores com políticas públicas que promovessem espaços de participação e que aspirassem a solucionar os problemas que os atingiam.

Rodrigo Baño (1985, pp. 25-6), influenciado por Touraine, nas suas pesquisas se perguntará em que medida o movimento popular é portador de uma real alternativa para a sociedade, ou seja, uma nova cultura e uma nova ética marcada pela ascensão de uma nova classe. A criação de um projeto popular alternativo é uma mudança histórica de classe, associada a uma nova ética, um novo espírito, e não apenas um programa que relaciona determinados meios frente a determinados fins. 
Insistimos, é o caráter da alternativa o que define os setores sociais relevantes e não o contrário. Esta alternativa, ao enfrentar a cultura dominante, lhe outorga significação a determinados setores sociais, e são estes os que podem produzir uma transformação social enquanto sejam capazes (e potencialmente o são) de imprimir um novo ethos cultural ao devir histórico.

O problema é justamente esse, de se o movimento popular tem chegado a apresentar um projeto alternativo que seja capaz de propor, ainda que como pura possibilidade histórica, valores e objetivos que orientem a sociedade de maneira distinta à imperante.

Com a introdução desta definição culturalista do projeto popular, o autor busca se distanciar das leituras estruturalistas do movimento de pobladores. Nelas, esse movimento corresponderia a categorias sociais determinadas: trabalhadores informais, pré-capitalistas, lúmpen, desempregados etc. A redução dos pobladores a uma destas categorias seria insuficiente para dar conta da complexidade do movimento. A questão é: a qual conflito social corresponde o movimento de pobladores? A inclinação do campo tem sido identificá-lo com o problema da habitação, ou seja, a exclusão do acesso ao espaço urbano de alguns setores. Porém, embora seja a demanda por habitação o que permitiu o reconhecimento do movimento de pobladores como tal, suas demandas têm sido mais amplas e heterogêneas. $\mathrm{O}$ que define o poblacional é o comunitário; a vida interna na población constitui uma comunidade de sujeitos que se inter-relacionam estreitamente e que criam e constroem sentimentos e metas comuns. A población parece mais uma espécie de sociedade de socorros mútuos, pois apresenta uma cooperação solidária em diferentes âmbitos (cuidado de crianças, empréstimos, ajuda frente a tragédias, festas etc.). A población é basicamente uma forma de comunidade. 
Então, se o movimento poblacional é expressivo de uma forma de comunidade, a comunidade de población, caberia se perguntar qual é o tipo de conflito ao qual corresponde. E a resposta parte precisamente dessa caracterização. O movimento poblacional é uma resposta popular à exclusão, segregação e atomicidade imposta pelo sistema de dominação que nega o sentimento de totalidade social (BAÑO, 1983b, p. 57).

A proposta do autor implica também redefinir o "popular" para além das concepções ortodoxas que estabelecem classificações sociais centradas no eixo proletariado-burguesia. Os setores sociais não estão pré-definidos; o que os define é o tipo de conflito que os desenvolve. O “popular” é entendido, assim, como uma forma de expressividade dos setores dominados que contém uma conotação política. O popular não é apenas a pobreza nem o proletário.

$\mathrm{O}$ projeto popular alternativo, do qual os pobladores fazem parte, se estabeleceu a partir de um conflito centrado na distribuição do produto social que não encontrava canais de participação institucional. Por isso, era captado geralmente apenas indiretamente por meio das explosões irracionais: as irrupções urbanas, tomadas de terreno e quebra-quebras. As revoltas urbanas exporiam conteúdos e demandas que já não são expressos no processo político; seriam o lado escuro da lua, um rosto do social que ao momento da eclosão estaria oculto, pelo qual seria ignorado. A realização do projeto político popular passará também pela confrontação criativa de duas dimensões: a da continuidade (organização) e a da quebra (momentos de crise) (BAÑO et al., 1981). Porém, a compreensão dos pobladores como os protagonistas destas explosões enquanto não-operários é insuficiente. A história passada do movimento popular e sua ideologia é uma forma de criação de futuro, e os realizadores do Projeto Popular Alternativo estão inseridos na cotidianidade da vida. $\mathrm{O}$ movimento poblacional corresponde à ação dos dominados defi- 
nidos em termos de exclusão social e de negação do sentimento de comunidade social. O que impulsiona o movimento de pobladores é a demanda por igualdade num sentido comunitário, daí a força do discurso da Igreja popular nas poblaciones. Nesse sentido, a mobilização do poblacional é mais antiditadura que pró-democracia formal: rejeita-se a ditadura pela ameaça que representa para a comunidade. Por isso, os partidos tendem a ser rejeitados também. Para serem aceitos, devem apresentar-se como partidos de base e antissistêmicos.

O movimento de pobladores substitui a relação direta com um oponente pela intermediação do Estado, porém a ditadura produz politização e ao mesmo tempo fecha os canais para a política. O regime provoca um processo de "politização objetiva”, mas ao mesmo tempo um processo de "despolitização subjetiva". As condições e consequências do movimento social são políticas, mas existe um baixo nível de consciência disso, pelo qual a capacidade para orientar estrategicamente o comportamento dos movimentos é baixa, em boa medida pela dificuldade dos partidos de serem os agentes clássicos da politização. $\mathrm{O}$ movimento social não consegue expressar suas reivindicações, pois o Estado nega essa possibilidade. Assim, o interesse do movimento se orienta a uma mudança da situação política como condição do seu desenvolvimento. O movimento social por existir é uma negação do autoritarismo. Porém, isso não coincide com níveis de consciência capazes de articular a politização em termos de projetos concretos. A ação dos partidos políticos, enquanto ato ilegal, os separa do movimento social, pelo medo à contaminação repressiva, o que é reforçado por um profundo desnível de consciência política entre a base e as lideranças dos movimentos sociais.

Por outra parte, existia uma enorme heterogeneidade na organização poblacional: cada instância obedecia a uma função diferente, era criada para enfrentar problemas específicos e não pre- 
tendia assumir uma representação geral dos pobladores. É preciso lembrar que

A política seguida pelo atual regime... foi a de desmontar as organizações; deslegitimar suas demandas como algo socialmente significativo, as reduzindo a problemas individuais, como o da incapacidade de poupança, o controle por amedrontamento policial dos moradores das poblaciones, e a tentativa de cooptação de organizações e lideranças através de diversos mecanismos e organizações estatais. É assim como toda a rede organizacional das Juntas de Vecinos e Centros de Madres estão hoje sob o controle absoluto do Estado e operam a miúde como instrumento de denúncia de atividades catalogadas como 'subversivas'. É frequente o amedrontamento de todo um bairro ou acampamento, como tem sido no caso dos 'operativos' dos primeiros tempos do regime, no qual se retinha a todos os moradores adultos em algum espaço aberto enquanto eram fichados e se checava com os prontuários dos aparelhos de inteligência; a arbitrariedade nas detenções por motivos ínfimos, as grandes batidas que ainda se continuam realizando, etc.

Em suma, tem resultado que apenas se promove e tolera aquelas organizações mais facilmente manipuláveis através dos recursos do Estado, e se dificulta e reprimem os brotos de organização autônoma que podem representar o perigo de algum tipo de ação reivindicativa. Por outra parte, a solução a certos problemas básicos, como o da habitação, se organiza sobre a base de sistemas individuais aos quais, em definitivo, muito poucos têm acesso à causa das exigências econômicas que implicam. Os problemas reais não apenas seguem existindo, como se agravam, e a solução governamental pareceria ser a de 'tampar' sua expressão organizada (CHATEAU, 1981, p. 36). 
No mundo poblacional, portanto, não existiria uma organização natural equivalente ao sindicato no mundo do trabalho. As Juntas de Vecinos, que poderiam cumprir esse papel, por terem sido intervindas pelo regime, não faziam parte do movimento. Ao mesmo tempo, as organizações poblacionales existentes, ao se funcionalizarem por problemas específicos, careciam de possibilidades teóricas de transcender, embora as organizações comunitárias desenvolvessem um tipo de solidariedade que ia para além da demanda imediata e existissem tentativas de conformação de instâncias coordenadoras (os referentes) que aspiravam a representar os interesses mais gerais dos pobladores. Mas, enquanto esses referentes eram a expressão partidária no mundo poblacional, reproduziam o problema de distanciamento do social e do político. Os partidos eram um dos grandes organizadores do movimento, porém não conseguiam dirigi-lo. Este fenômeno alimentava as especulações sobre a autonomia do movimento, mas ela seria mais o produto da fraqueza dos partidos que de seu fortalecimento.

Porém, na medida em que os partidos sobrevivem e começam a se rearticular, se faz cada vez mais necessário para eles aumentar sua presença no movimento social. No fim, sob um regime autoritário como o chileno, o movimento social é a forma de fazer política. Por esta razão se produz a situação de que, ainda num processo de despolitização subjetiva, se mantêm a representação de partido no nível das mais altas lideranças do movimento poblacional e sindical [...] Isto não significa que se tenham desenvolvido fortes organizações autônomas capazes de conformar um grande movimento social. Pelo contrário, a reorganização do movimento social, desarticulado pelo regime militar, se consegue numa colaboração muito estreita com os partidos políticos, os quais, na falta de um espaço político, voltam toda sua ação para o movimento social (BAÑO, 1983a, p. 41). 
O problema é que o social e o político apareciam divorciados na prática. Com a eliminação dos partidos políticos, a participação em movimentos sociais virou a principal forma de fazer política concreta, porém os partidos buscaram ser mediadores entre o particular e o geral frente aos movimentos. Mas, embora os movimentos pudessem reconhecer a identidade e o papel do partido na política, a diferenciação é tal que eles não se comprometiam com essa política. O Movimento de Pobladores estabelecia uma diferenciação entre o caráter nacional abstrato da política de partido e o caráter do "concreto vivido" do próprio movimento. Isto foi produto da sociabilidade comunitária que dominava a lógica poblacional. A especialização do político que os partidos representam negava o sentido de totalidade concreta do Movimento de Pobladores. Por isso, a desconfiança com a política partidária e com o poblador transformado em político, ceticismo que ia além do temor à repressão pelo contato com eles.

Outra limitação para a consolidação do projeto popular alternativo foi que a definição do poblacional e do sindical pareciam não ser complementárias. Enquanto os pobladores se guiavam para uma sociabilidade comunitária, os trabalhadores o faziam por uma societal. Ou seja, se entre os pobladores predominava uma solidariedade mecânica, nos sindicatos primava uma de caráter orgânico. Comunidade poblacional, por um lado, e sociedade sindical, por outro, caminhavam por trilhas que não necessariamente se encontravam na prática. A conclusão é clara: não existem experiências significativas de relação entre o sindical e o poblacional (BAÑO, 1983a). Mas a possibilidade de articular um movimento popular poderoso depende, em boa medida, de que os partidos possam complementar o elemento comunitário e o elemento societal, superando a divisão do social e do político.

Neste ponto, embora o que defina o movimento seja o comunitário, a prática organizativa não seria suficientemente consistente como para configurar um movimento social portador de um 
projeto alternativo. Os pobladores se movimentam, mas não constituem um movimento social como tal, e já começa a se desenhar a discussão sobre o estatuto do movimento. Precisamente o tópico da próxima seção.

\section{O Movimento de Pobladores como anti-movimento social}

Apesar das diversas formas de protesto e organizações que os pobladores opuseram contra a ditadura, para Alain Touraine, a mobilização dos pobres urbanos de Santiago não tinha os elementos suficientes para constituir um movimento social, segundo os parâmetros que o próprio autor fez célebres: "Se me permitem, no meu vocabulário diria que não constituem propriamente um movimento social, mas um movimento histórico, onde o tema não é manejar os recursos de uma sociedade, de um tipo societal, mas manejar o processo de transformação social cujo agente central não é uma classe dirigente, mas o Estado" (TOURAINE, 1987, p. 221).

Este diagnóstico não foi menor, pois a conceitualização dos movimentos sociais feita pelo sociólogo francês influenciou praticamente todos os autores da década de 1980 que estudaram os movimentos populares e seu possível papel na transição democrática. Com uma trajetória intelectual e pessoal fortemente ligada à América Latina e notadamente ao Chile, Alain Touraine (1973) exerceu uma influência direta sobre muitos intelectuais latino-americanos, orientando muitas das teses de pós-graduação de autores preocupados com a questão dos movimentos sociais e indiretamente mediante a penetração de sua teoria da modernização e seus métodos de pesquisa (intervenção sociológica).

Para Touraine (1994), a modernidade não é apenas o processo de racionalização de todos os âmbitos da vida; também é a formação de um sujeito no mundo que se responsabiliza por si próprio e pela sociedade. $\mathrm{O}$ sujeito estabelece uma relação de com- 
plementaridade e oposição à racionalização. $\mathrm{O}$ mundo moderno está penetrado pela referência a um sujeito que é liberdade e que se autoconcebe como ator, o sujeito é essa vontade de agir e de ser reconhecido como ator. Este é quem modifica o ambiente material e social no qual está inserido: a divisão do trabalho, as relações de dominação, as orientações culturais, a reprodução da sociedade. O sujeito é, portanto, a autotransformação de si próprio em ator. Subjetivação é o processo de penetração do sujeito no indivíduo ou a transformação parcial do indivíduo em sujeito. Logo, a subjetivação não pode ser confundida com o individualismo, aliás, uma das principais formas que pode tomar o sujeito é a de movimento social. Na constituição do sujeito não se pode separar o indivíduo de sua situação social. A subjetivação pode ser compreendida como um movimento cultural, no qual o sujeito só existe como oposição à lógica da ordem, ou seja, como movimento social. Um movimento social é simultaneamente um conflito social e um projeto cultural, pois sempre aspira à realização de valores culturais na sua vitória frente a um adversário social; não é apenas uma luta reivindicativa, tem que ser portador de valores, propor orientações culturais novas. A centralidade dos movimentos sociais é tal para Touraine que chegará a propor substituir o conceito de classe social pelo de movimento social, assim como a análise de situações pela análise da ação.

É neste ponto que emerge com força a ideia de novos movimentos sociais, nos quais estaria presente uma consciência moral ligada à defesa da identidade e da dignidade de quem luta contra uma opressão extrema. Esses movimentos falam mais de autogestão do que de sentido da história, de democracia mais do que de tomada do poder, propondo uma nova maneira de conceber o conflito social.

Enquanto os antigos movimentos sociais, sobretudo o sindicalismo operário, se degradam e se transformam em grupos de 
pressão política ou em agentes de defesa corporativa de setores da nova classe média assalariada antes do que defensores das categorias menos favorecidas, esses novos movimentos sociais, mesmo quando carecem de uma organização e uma capacidade de ação permanente, fazem surgir já uma nova geração de problemas e conflitos sociais e culturais. Já não se trata de se enfrentar para obter a direção dos meios de produção, mas agora se trata das finalidades dessas produções culturais que são a educação, os cuidados médicos e a informação das massas (TOURAINE, 1994, p.243).

Embora Touraine (1989) se assuma como responsável pela introdução do conceito de novos movimentos sociais, não reconhece nos estudos sobre estes, na América Latina, o "sujeito" que substitui a antiga classe operária na criação de um projeto de novas normas e valores sociais na sociedade programada. Os movimentos estudados na verdade mostram os limites ou as crises do sistema político, e não a presença de atores coletivos capazes de opor outra forma de organização social. São movimentos que negociam mais facilmente com o Estado do que mobilizam a população para uma luta de alcance geral.

Na América Latina (TOURAINE, 1976), estaria presente uma interdependência mais acentuada das três formas de conduta coletiva por ele definidas: a defesa de interesses coletivos, a pressão extrainstitucional e os movimentos sociais. $\mathrm{Na}$ defesa de interesses coletivos podem se enquadrar as lutas salariais ou a ação dos grupos de pressão. A pressão extrainstitucional seria reações à incapacidade das instituições políticas de fazerem os ajustes necessários para a reprodução do sistema. E os movimentos sociais, como já dito, seriam um tipo de conflito social que opõe formas sociais contrárias de utilização dos recursos e dos valores culturais. Porém, na América Latina, os movimentos sociais sempre permanecem subordinados às intervenções políticas e, sobretudo, à ação do Estado, pelo qual a formação de um movimento social autônomo fica comprometida. 
$\mathrm{O}$ que em outros lugares seriam movimentos sociais, na América Latina aparecem como respostas positivas ou negativas às intervenções do Estado (TOURAINE, 1989).

Muito do que é tomado, na América Latina, por novos movimentos sociais, na verdade, segundo o autor francês, não possuem uma concepção da sociedade ou da democracia e, em realidade, buscam a afirmação de direitos fundamentais como pessoas e a denúncia da situação injusta na qual se encontram por causa do regime político ou econômico. Neles, e notadamente no Movimento de Pobladores, o que está em questão é uma vontade de cidadania, o que prima é uma consciência de pertencimento a uma comunidade que aspira mais à integração social e política e menos à construção de um conflito que oponha uma categoria social sobre outra. Isso explicaria os vieses que esses movimentos adquirem quando expressam um radicalismo conservador ou quando misturam os discursos mais extremos com o clientelismo mais autoritário.

É falso representar a América Latina como sublevada por movimentos de base que reinventariam a sociedade e a vida política; inversamente, não se pode afirmar que todas as formas de ação coletiva são demandas sociais à procura de uma oferta política que encontrarão cedo ou tarde, ou que são sinais de uma recusa global da sociedade. O conceito de movimento social é de uma importância central não porque descreve realidades maciças, mas porque ele indica o lugar onde tendem a se formar os conflitos mais centrais, onde a capacidade dos homens de fazerem a sua história atinge o nível mais elevado. A América Latina não é um continente épico e é raro que nela se formem movimentos sociais poderosos. Ainda mais raro hoje do que ontem, porque o crescimento é mais favorável às mobilizações do que à crise. Porém, mesmo se esse lugar central é fracamente ocupado, é preciso reconhecer sua centralidade e identificar as forças favoráveis ou 
desfavoráveis à formação de novos atores sociais centrais, sem a existência dos quais não há saída para a dependência, nem para o desenvolvimento (TOURAINE, 1989, pp. 283-4).

Particularmente em relação ao Movimento de Pobladores chileno, o autor é descrente de que condutas ligadas à pobreza necessariamente possam levar a um nível elevado de ação coletiva. $\mathrm{Na}$ ação coletiva dos pobres urbanos, misturam-se, às vezes incoerentemente, a ajuda mútua, a negociação com autoridades, os protestos “exemplares” e a violência. A mistura constante de todos esses aspectos, assim como a presença simultânea da experiência da pobreza e da exclusão, dificilmente poderiam levar a que estas situações derivem em embriões de uma ação revolucionária, como alguns autores e intelectuais de esquerda viam, ou que sejam simplesmente expressão de condutas de desorganização social ou delinquência.

Portanto, não se deve falar de movimentos sociais urbanos como se, a partir dos bairros mais carentes, se desenvolvessem lutas sociais capazes de elevar-se ao nível político. Em vez disto, observa-se que, em alguns bairros, surgem reivindicações que não chegam a encontrar expressão política autônoma, mas que podem ser utilizadas por intermediários como meio de pressão sobre a prefeitura, os serviços públicos e até sobre o Estado. Estes, que são diretamente responsáveis pelas más condições de vida dos moradores, transformam ou procuram transformar em clientela política os grupos que apresentam as reivindicações. O que está longe da ideia de um movimento autogestionário que associe, à sua ação, reivindicações que se referem a todos os aspectos da vida, do trabalho à moradia, da educação à saúde. É por isto que é tão fácil para demagogos ligados à oligarquia ou procurando constituir um poder pessoal, criar uma clientela e pontos de apoio nos bairros populares (TOURAINE, 1989, p. 275). 
Os pobres urbanos afirmam seu direito à existência contra uma ordem social que os marginaliza, e sua ação toma a forma de um protesto moral, sendo mais expressiva que instrumental. Sem conseguir definir um adversário com precisão, os pobladores fazem um apelo à reconstituição da sociedade ou à recriação da comunidade (abrir a sociedade mais que mudá-la). O movimento de pobladores, mais do que um movimento na disputa do político, estava voltado para dentro, na defesa da comunidade e dos seus direitos; era um movimento mais de implosão do que de explosão. Embora possam transformar sua ação em violência política, dificilmente podem se expressar institucionalmente, pois são mais um movimento de resistência. Por isso a promessa que alguns viam nos pobladores, como o fator que terminaria por derrubar a ditadura, não se cumpriu. O que em realidade estava acontecendo era a reconstrução do sistema político e, nesse quadro, os movimentos de base testemunharam como pouco a pouco perdiam sua autonomia. Não eram um movimento social, mas "os intelectuais, insatisfeitos com as formas anteriores de ação política e principais agentes do protesto moral contra a ditadura, apoiam esses movimentos e os apresentam como fatores de rejuvenescimento e de extensão da democracia" (TOURAINE, 1989, p. 278). Embora não seja possível falar de movimentos sociais na América Latina, isso não é sinônimo de obviar sua importância nas sociedades em questão, mas é preciso definir com precisão o status teórico dessas expressões para não criar falsas expectativas:

Mas será que se deve considerar esta diversidade das condutas coletivas como consequência direta de uma situação de exclusão e de impotência? Ou, ao contrário, não se poderá ver aí a fragmentação, a desintegração de um movimento social impossivel e que só se manifestaria à custa da alteração de temas sociais em temas morais ou religiosos? Aqueles que são definidos e situados apenas negativamente, só podem criar um desejo de movimento 
social, com o risco até de produzir o que chamo de um antimovimento social, isto é, uma comunidade integrada e homogênea que traz em si exatamente o inverso do conflito aberto que define um movimento social (TOURAINE, 1989, p. 285).

Esta noção do Movimento de Pobladores será recepcionada praticamente sem questionamentos por um grupo de pesquisadores chilenos (DUBET et al., 1989), os quais, encabeçados por um dos colaboradores mais próximos de Touraine, François Dubet, utilizaram o método de intervenção sociológica (TIRONI et al., 1986) para analisar os pobladores. A intervenção sociológica (TOURAINE, 1986) é uma análise da autoanálise de um movimento coletivo mediante o estudo das condutas coletivas, das formas de organização social, da compreensão que os atores fazem do conflito do qual participam e da apropriação dos padrões culturais com os quais uma coletividade constrói normativamente sua relação com o meio ambiente. $\mathrm{O}$ método da intervenção sociológica permite determinar se um movimento é social (uma ação coletiva conflitiva pelo controle social dos modelos culturais) ou histórico (seu objetivo não é controlar ou transformar o sistema de dominação social, mas passar de um tipo de sociedade a outro). $\mathrm{Na}$ intervenção sociológica, o grupo de atores, que compartem o fato de terem participado num mesmo tipo de ação coletiva, em determinado momento é confrontado com as hipóteses dos analistas, com a expectativa de que os atores incorporem esta visão à sua autoanálise e modifiquem sua conduta, produzindo-se o processo de conversão.

Estes autores (DUBET et al., 1989) mostraram que os pobladores possuem uma consciência de exclusão (do consumo) e uma consciência de exploração (como operários), encontrando-se entre dois polos de tensão identitária. Há neles, portanto, uma inconsistência estatutária, mais que uma anomia. Esta dupla 
identidade é a expressão da dualidade de relações sociais típica de sociedades dependentes.

A exclusão e exploração, assim como as opostas tendências à ruptura e à participação determinam o sistema de ação dos pobladores, definidos por quatro orientações básicas: (A) Reivindicação, lógica de relação entre a definição do ator como explorado e inclinação à participação, sendo uma espécie de colonização da ação sindical nas poblaciones; (B) Participação Populista, interação entre o polo da exclusão e o da participação, sendo uma afirmação da necessidade de reconstituição do espaço político pré-golpe, que permitia a participação dos pobladores como cidadãos; (C) Defesa Comunitária, dada pela relação Exclusão/Ruptura, lógica que se identifica com uma defesa da vida contra uma ordem considerada como injusta, aspira-se à integração do grupo como povo, sendo a expressão mais presente nas poblaciones, o sustento das redes de organizações locais e dos protestos morais que afirmam a dignidade e solidariedade do povo, sendo o principal articulador desta lógica a Igreja Popular; (D) Ruptura Revolucionária, dada pela Exploração/Ruptura, que se afirma a partir da revolta do povo explorado ou privado de trabalho frente ao Estado, no qual se reivindica a violência política como instrumento para construir uma nova ordem social.

A ação reivindicativa dos pobladores, cuja manifestação mais clássica é a tomada de terrenos, é a que marcou a aparição do movimento na sociedade chilena. Nela, os pobladores não aparecem como portadores de um projeto, uma utopia ou uma organização política autônoma, mas o fazem como uma força que reivindica frente ao Estado sua integração, o qual coopta parcialmente os grupos marginais. É o que se conheceu como Estado de Compromisso chileno. Porém, a ditadura desmontou este sistema que outorgava centralidade aos partidos no processo de mediação frente ao Estado. Com isso, os pobladores começam a acentuar sua desorganização e atomização, mal têm tempo para sobreviver, organizam-se 
para obter ajudas urgentes, sem uma noção de um futuro comum, e viram uma massa dispersa e dependente.

A Participação Populista, que busca reconstruir um vínculo de pressão e dependência frente ao Estado, estabelece uma autodefinição do mundo poblacional como comunidade excluída e privada de mecanismos de expressão, assim como de meios de integração no sistema político. Nessa ação, o ideal democrático é fraco, e o ódio à ditadura não se traduz necessariamente em aspirações democráticas. O que prima é mais uma nostalgia do modelo populista que permitia canalizar as demandas poblacionales, que foi erradicado pela ditadura militar.

A Defesa da Comunidade seria uma forma de recuo protetor, um apelo à resistência interna. Para resistir às consequências econômicas e sociais do regime é preciso afirmar e se apoiar na comunidade, ou seja, na experiência local dada por compartilhar uma marginalidade comum. Apoiada no cristianismo popular, a ação comunitária busca se contrapor à tendência "natural" à anomia e à desorganização social próprias de setores excluídos. A representação das relações sociais é feita em termos morais: a ditadura é um novo episódio de martírio do povo. Porém, não representa um projeto de futuro, é mais uma reação defensiva contra a miséria e a anomia, embora seja a ação com mais presença no mundo poblacional.

A Ruptura Revolucionária que promove a mudança do sistema social como um todo é vista pelos autores como uma forma extrema de voluntarismo. Em nome de um projeto político superior, ultrapassam-se os interesses imediatos, as definições reivindicativas e a ação comunitária dos pobladores. Estes nem são os principais protagonistas dessa mudança, esse papel é dos trabalhadores. A questão democrática fica também num segundo plano frente à questão do socialismo. A violência social espontânea trata de ser traduzida numa linguagem política pelos militantes, outorgando a ela uma posição central na mudança possível. 
Embora as quatro lógicas formem um sistema, elas estão desarticuladas, e cada tipo de ação se identifica com uma estratégia política opositora que tende a ampliar a desunião da ação dos pobladores, distanciando o social e o político. Cada lógica se separa na teoria e na prática definindo a um ator, apesar do seu poder de mobilização, incapaz de se constituir como um movimento social articulado. Ao mesmo tempo, o Movimento de Pobladores é incapaz de hierarquizar suas ações e reivindicações, suas estratégias, assim como constituir um projeto geral.

Nem 'pura' classe social, nem 'pura' comunidade, nem totalmente integrados à nação, nem totalmente em ruptura, os pobladores estão situados em sistemas de referências múltiplos, circulam entre um e outro e, apesar de uma situação insuportável, apesar do seu peso demográfico, apesar de suas capacidades de mobilização que não faz deles uma massa alienada e apática, eles não se constituem um movimento social construído por um modelo de relações sociais, uma identidade relativamente homogênea e um projeto. Mas eles não formam tampouco uma dessas massas anômicas e mobilizáveis por uma contra-elite ou por um Estado, como essas que descrevia Germani. Eles são ao mesmo tempo mais e menos que isso, eles são um ator desarticulado (DUBET et al., 1989, p. 55)

Ator desarticulado, o Movimento de Pobladores é incapaz de constituir um movimento social, ou seja, de pôr em questão o sistema cultural imperante oferecendo uma alternativa com normas novas. Embora os pesquisadores de SUR insistissem em afirmar que isso não significava subestimar a importância dos pobladores para a sociedade chilena, sua limitação para constituir um "verdadeiro" movimento social foi a principal conclusão do estudo.

Se nós aceitamos definir um movimento social como uma ação de classe confrontando uma dominação social a fim de garantir um 
controle e uma participação aberta à produção e à organização da sociedade, os pobladores não são um movimento social. Mas este julgamento analítico não é nem um julgamento de valor, nem um julgamento histórico. Ele não implica que a ação dos pobladores não seja importante e que ela não possa desempenhar um papel considerável na sociedade chilena (DUBET et al., 1989, p. 57).

Todo movimento social possui lógicas diferentes na sua ação, mas o que define sua força é sua capacidade de articulação. Isso é o que faz do Movimento de Pobladores um movimento paradoxal: embora possua uma forte experiência de vida em comum e apresente uma grande rejeição ao regime ditatorial, suas orientações são extremamente diversas. Por um lado, são expressivas demais; por outro, instrumentais demais. Os pobladores não possuem um princípio de ação central que outorgue estabilidade ao movimento, ou seja, há mobilizações sem movimento, são uma soma de reivindicações de diferentes tipos, não possuem um projeto de organização da sociedade, se balançam entre a dependência e a autonomia, e o social e o político estão divorciados na prática.

Por causa de sua exclusão e de sua marginalidade, nunca os pobladores têm podido constituir um movimento social real, e é só de maneira metafórica e ideológica que alguns têm chegado a analisar as lutas dos marginais nos mesmos termos que uma ação de classes ou o movimento operário. Da mesma maneira, nunca a luta dos pobladores pôde ser identificada como uma luta revolucionária capaz de impulsionar uma mudança de tipo de sociedade (DUBET, 1987, p. 98).

No caso dos protestos, mais que manifestações políticas, eram resistências comunitárias fronteiriças com ações desviantes. Em certa medida, eram manifestação da anomia e do desespero provocado pela exclusão, tendo o efeito de isolar as poblaciones do 
resto da sociedade e de alimentar ainda mais o mito das classes perigosas.

Mais profundamente, os pobladores, enquanto tais, não possuem consciência de classe, não se definindo por sua oposição à um adversário social e não possuindo um projeto de sociedade autônoma. Suas representações das relações sociais são muito mais organizadas em termos de distância social e de exclusão que de conflito; seu interlocutor não é uma classe, mas um Estado do qual podemos nos distanciar pela revolução ou pelo isolamento comunitário, mas que resta sempre interpretado como o único agente possível da integração (DUBET et al., 1989, pp. 176-7).

Para Eugenio Tironi (1987a, 1987b) o Movimento de Pobladores era incapaz de gerar uma identidade coletiva duradoura, pois suas formas de ação eram defensivas e, mais que um movimento social, era um movimento de militantes que não encontravam os caminhos para construir uma prática de representação num Estado autoritário. Embora adaptados à modernidade, sua inclusão não era total, pois experimentavam formas de marginalidade econômica, social e política. A marginalidade cobra centralidade até nas discussões sobre democracia, e não como se compreendeu anteriormente com DESAL, ou seja, como um mundo marginal totalmente excluído da sociedade moderna. Para Tironi, os marginalizados estão parcial e diversamente integrados/ excluídos à sociedade. A principal ameaça para a sociedade chilena é a desintegração social encarnada nos pobladores. A "revolta dos pobladores" é a expressão desse sentimento de exclusão frente a uma ordem social na qual não podem participar legitimamente. Porém, os pobladores não têm condições de transformar sua revolta numa ação social organizada, nem numa demanda de mudança consistente, daí as formas violentas com as que se expressa seu protesto. O movimento de pobladores é um movimento antissocial: 
No caso que estamos estudando dos pobladores nos encontramos primeiramente com a desarticulação entre as orientações ofensiva (a ação reivindicativa) e defensiva (a ação comunitária); e, em segundo lugar, com uma situação onde um e outro tipo de ação encontram obstáculos que levam ambas a um ponto crítico. Nestas circunstâncias parece difícil, por exemplo, se referir aos pobladores como um 'movimento social'. Em efeito, a crise da ação reivindicativa e os limites do comunitarismo desembocam num fenômeno que corresponde bastante aproximadamente ao que Touraine denomina, às vezes genericamente, como um 'anti-movimento social', cuja expressão mais patente é a violência (TIRONI, 1986, p. 30).

Embora, com os protestos, os pobladores conseguiram visibilidade, ela era espectral, pois sua ação carecia de articulação suficiente para que pudessem deixar sua marca na edificação de uma nova ordem democrática. Essa falta de articulação os transformava em incontroláveis, o que não impedia que pudessem estar "em disponibilidade" para passar da apatia a um tipo de mobilização até milenarista. Por isso, a classe política precisava contribuir para que a "agitação nas poblaciones" virasse ação estruturada, e para isso tinham que deixar de compreender os pobladores apenas como ameaça à ordem democrática e incorporar a questão da integração social à nova arquitetura democrática por construir.

$\mathrm{O}$ estrato poblacional onde com maior força se expressaria esta tendência à desarticulação seria a juventude (VALENZUELA, 1984, 1986). Sendo o setor que mais participou dos protestos populares, a rebelião na qual os jovens participaram poderia ser vista como o sintoma mais claro da frustração frente à modernização, a qual ameaçava com introduzir uma situação de desintegração cultural e da vida coletiva e, ao mesmo tempo, de atomização das relações sociais, produzindo anomia. Com a introdução do conceito clássico de anomia, Eduardo Valenzuela buscava expressar a 
ausência normativa produzida pelo império das relações de mercado no Chile neoliberal. Os jovens teriam concentrado os efeitos da crise industrial e do ajuste estrutural da economia: desarticulação do mundo laboral, frustração educacional, desequilíbrios familiares e exclusão política. Com o bloqueio dos principais mecanismos de integração à sociedade para os jovens do mundo popular, prevaleciam espaços de sociabilidade pouco estruturados: o mundo das ruas. Os jovens possuíam relações privadas e de trabalho pouco duradouras, fugiam do entorno familiar, viviam um ócio forçoso etc. A anomia seria o resultado da própria modernização neoliberal e não o produto da decomposição de estados tradicionais, provocando uma crise de identidade. Assim,

A rebelião dos jovens é o fruto destas condições: seu substrato será a crítica, mais ou menos consciente, da modernização e se expressará de muitas e diferentes formas, seja na generalização do uso de drogas e busca de evasão através do prazer imediato, seja na restituição dos nexos comunitários (as comunidades cristãs de base), seja como recuperação de princípios de identidade coletiva (o allendismo) ou simplesmente como revolta anômica, ou seja, como agressão desestruturada contra a ordem social (VALENZUELA, 1984, p. 51).

A visão do autor será em boa parte coincidente com a de outros que tomaram como objeto os jovens populares. José Weinstein (1988b), por exemplo, destacou o papel do que ele entendia como a juventude subproletária nos protestos populares.

Durante os anos 1983 e 1984 se produziu, nas grandes cidades chilenas, um fato social e político significativo: frente às sucessivas convocatórias a protestar contra o regime militar, formuladas pela oposição política, a juventude subproletária respondeu massiva e vigorosamente. Seu protesto consistiu numa série de ações 
netamente ilegais e de caráter violento: barricadas, assaltos ao comércio estabelecido, enfrentamentos com a polícia, manifestações nas ruas, destruição de certos símbolos da ordem, incêndio de locais do governo, apedrejamentos contra os ônibus... Estes jovens se apropriaram do espaço de suas poblaciones marginais e desenvolveram um conjunto de ações de desobediência que foram para além das intenções e as orientações dos dirigentes políticos da oposição. O balanço dos Protestos Nacionais, desde o ponto de vista das atividades de oposição, como do número de vítimas da repressão, deixou em evidência o papel que jogou a juventude subproletária nesta conjuntura política (WEINSTEIN, 1988a, p. 5).

A novidade proposta por este protagonismo juvenil estabelecia como desafio a caracterização deste grupo geracional. A juventude popular teria vivido um processo de desproletarização, não pertencendo ao setor formal do emprego e não recebendo nenhum tipo de assistência do Estado, oscilando entre o desemprego e o subemprego. Os jovens seriam vítimas e beneficiários da modernização, pois se por um lado eram os mais atingidos pela crise de habitação e de emprego, foram uma geração significativamente mais escolarizada e com acesso a meios massivos de comunicação, o que aumentou a brecha em relação a seus pais, mas consolidou nexos simbólicos com os membros da sua própria geração (WEINSTEIN, 1991). Porém, ao mesmo tempo foi uma geração que se socializou no medo ao Estado, com um sentimento de indefensibilidade frente às ameaças e sem resguardos institucionais, desconfiando das escassas instâncias de participação oferecidas pelo Estado (WEINSTEIN, 1988b). Esses jovens tinham uma inclinação às soluções individuais mais que coletivas, primando uma adaptação atomizada, apesar da existência de uma minoria politizada nos bairros populares. Nesse contexto, era difícil a elaboração de uma plataforma reivindicativa frente a um Estado ausente 
e acossador, e o descontentamento contra ele se expressava como rebeldia militante ou desviada (droga, delinquência) na ruptura, mas sem meios cotidianos para expressá-lo. Daí a importância do protesto para esses jovens: eles eram manifestações massivas, territorializadas, violentas, geracionais, inorgânicas e viscerais. Esses protestos expressariam os efeitos da marginalidade sobre a ação coletiva: em face ao bloqueio dos mecanismos de participação como grupo, a tendência é a ação extrainstitucional. Sua situação de exclusão e menor responsabilidade social os inclinaria a uma maior aventura e risco, e, ficando fora do jogo reivindicativo, suas ações eram globais (rebelião frente ao regime) e imediatadas. Eles não podiam esperar, e seu principal grito era: "morir luchando, de hambre ni cagando". O protesto não expressava um projeto; antes, era a manifestação de descontentamento frente a uma situação geral de múltiplas privações. Assim, os protestos eram:

Violência visceral, mas também inorgânica. A participação massiva tem lugar com espontaneidade e não é canalisada por grupos mais organizados e permanentes. A participação se apoia, antes de tudo, sobre o 'tecido' informal no qual o jovem subproletário se move coditianamente: seu grupo, constituído por seus pares. Embora haja, na base da mobilização dos jovens, uma 'organização' anterior, se trata em realidade de grupos naturais, formados por amizade, fundamentalmente masculinos, nos quais passam o tempo vazio do dia. Os diferentes pequenos grupos que agem não estão estruturados em função de suas atividades nem estão relacionados entre eles (WEINSTEIN, 1988b, pp. 49-50).

Segundo Valenzuela, as orientações dos jovens populares estariam dadas entre os não organizados pelo retraimento (drogas) e a rebelião (revolta) e entre os organizados pelo refúgio comunitário (comunidades cristãs) e a mobilização (radicalismo). Como consequência, a mobilização dos jovens careceria de princípios po- 
sitivos de ação, seria essencialmente negativa, com pouca identidade e sem projeto histórico de sociedade. A maior parte dos jovens que participavam dos protestos não estavam organizados, incluindo viciados em drogas e delinquentes, por isso o protesto tomava mais a forma de uma revolta contra a sociedade organizada, de caráter radical e em oposição à institucionalidade. Basicamente, a rebelião dos jovens era uma revolta anômica, uma mobilização inorgânica de agressão contra as instituições sociais.

Resulta interessante ressaltar que, embora absolutamente coerente com as leituras de inspiração tourainianas, a interpretação de Valenzuela ressuscita também com mais força a teoria da marginalidade. $\mathrm{O}$ termo anomia em particular figurava frequentemente nas análises dos grupos "marginais" urbanos na América Latina (MORSE, 1971). Sem dúvida, no diagnóstico de incapacidade de articulação de uma ação estruturada, existe uma proximidade entre os autores aqui revisitados e os teóricos de marginalidade, embora mais sofisticada, pois nesta última se negava a capacidade de organização popular; porém, com isso aparece também uma ruptura com o teórico inspirador destas interpretações. Alain Touraine (1989) sempre se negou a compreender as poblaciones como o lugar da desorganização ou da anomia, rejeitando as leituras da marginalidade (TOURAINE, 1976), mas valorando o conceito de Cultura da Pobreza de Lewis como uma das manifestações possíveis a ser encontradas nos bairros populares da América Latina.

Um seminário organizado pela CLACSO e pela Universidade das Nações Unidas, em 1985, em Santiago do Chile, sobre os movimentos sociais e a luta democrática, do qual participaram, entre outros, Guillermo Campero, Vicente Espinoza e Eduardo Valenzuela, teve como principal conclusão o seguinte:

As mobilizações e lutas em que se involucraram os grupos sociais mencionados [trabalhadores, pobladores, mapuches, jovens, etc.], embora os perfile como agentes ou sujeitos dotados de certa ca- 
pacidade de intervir coletivamente na vida social - o que permite se referir a eles como atores - não parecem ainda ter dado constituição consistentemente a movimentos sociais propriamente tais. Em efeito, quase todos eles possuem uma definição de identidade mais ou menos distinguível, mas ela está marcada amiúde por um sentido defensivo, o que os limita para jogar um papel mais dinâmico.

Portanto, não se manifestam ainda como portadores de uma imagem alternativa de sociedade suficientemente nítida e compartilhada, capaz de ser proposta e percebida como convocante para o resto da sociedade. Em consequência, todos eles são atores com uma orientação antiautoritária definida, mas seu sistema de oposições e de alianças não está claramente comandado por uma estratégia de transformação e por uma lógica persistente de jogar um papel central na sociedade.

O anterior não sugere que, no quadro de condições geradas pela situação de relativa inorganicidade estrutural e política e de obstáculos à legitimação da ação coletiva, as mobilizações sociais que surgem com a politização se definem ainda - sobretudo - como lutas antiautoritárias, mais do que como anticapitalistas ou pró-socialistas, por considerar apenas um exemplo indicativo.

Esta hipótese geral indica que as mobilizações são principalmente lutas para enfrentar a exclusão, seja esta econômica, sócio-política ou cultural. Naturalmente, cada setor social específico manifesta distintas potencialidades de superação desta condição mais bem defensiva (CAMPERO, 1986, p. 15).

Para o autor referido acima, a ditadura fracassou no seu intento de fundar uma sociedade sem atores sociais, e os protestos foram prova da reemergência de dinâmicas de luta coletiva, apesar 
de todos os esforços do regime para neutralizá-las. O alto grau de espontaneismo que primou nos protestos permitiu a convergência dos setores que conservavam mais organicidade (sindicatos) com os mais dispersos e atomizados (jovens e pobladores). Na base deste processo de reconstituição dos atores sociais, estava a crise econômica (1981) que levou também a uma crise do projeto social do regime. Com a reestruturação econômica, desenvolvia-se uma massa marginal urbana excluída e empobrecida que, porém, não dava origem a um novo ator social concreto. As mudanças na estrutura social não teriam dado procedência a novos atores, pelo contrário, teriam enfraquecido os já existentes (trabalhadores). Com a crise, teriam perdido centralidade os movimentos propriamente classistas e se massificaria um segmento social informalizado e, como tal, altamente inorgânico, heterogêneo e apenas subsistente. As poblaciones chilenas seriam o lugar onde se expressariam mais fortemente estas formas de exclusão, porém os pobladores não desenvolveriam uma consciência coletiva enquanto expulsados da sociedade. Embora existissem traços de identidade territorial e política, ela não seria suficiente para gerar uma matriz cultural e política internalizada ao modo de uma identidade comunitária (CAMPERO, 1987a). Os pobladores se consideravam vítimas da crise econômica e não de um apartheid social, por isso sua oposição à ditadura não se expressava como uma ruptura com a sociedade. Eles estavam tensionados pelos estímulos à ruptura e sua vontade de integração social, debatiam-se entre sua identificação com a población e sua aspiração social de sair dela. Os pobladores às vezes agiam dentro do sistema e outras vezes fora: se a exclusão estimula formas de rupturismo, as organizações de autoajuda promovem a integração.

Para Campero (1987b), também o Movimento de Pobladores se debatia entre duas lógicas globais de ação: a sobrevivência e a ação política. A primeira não consegue transcender o defensivo e a segunda não consegue superar a separação entre o ativo políti- 
co (os militantes) e as bases sociais. Nenhuma delas consegue uma ação representativa nem articuladora das outras práticas, aliás, são formas de particularismo. Apenas uma oferta política que formule um exercício de integração e participação terá possibilidades de que a demanda dos pobladores se encontre com ela. Se isso não se concretizar, é possível que os pobladores continuem no isolamento.

Este 'tecido social' poblacional parece ser então uma coluna vertebral que insiste em persistir como energia da sociedade frente à força centrífuga do militarismo e do mercado 'selvagem'. Mas esta energia, como veremos no estudo, não é apenas de resistência, de refúgio no 'apartheid', mas também de luta pela reintegração, de luta por vencer a segregação; assim, em nossa hipótese, desde a luta pela sobrevivência até aquela definidamente política, a ação social dos pobladores está atravessada e tensionada por essas duas dimensões: a de recuo a um comunitarismo defensivo, que pode também se manifestar na violência ativa, e a de se rearticular a um processo de coesão social global, ao qual sua memória histórica e a persistência de um sentido político de cidadania lhes impede renunciar (CAMPERO, 1987a, p. 36).

O mundo poblacional e sua ação não são homogêneos. A ação de sobrevivência e a ação de mobilização social e política são duas dimensões que não mostram uma articulação estável entre elas, embora possam existir momentos conjunturais e parciais de integração, também graças aos esforços da Educação Popular por mediar estas duas orientações globais de ação.

A ação de sobrevivência comunitária está na base da ação poblacional, é uma ação coletiva de ajuda mais que reivindicativa e não se define por objetivos de pressão ante a autoridade pública. Os grupos são mais espaços de refúgio e de defesa diante dos efeitos desintegradores da exclusão social, tomando a forma de núcleos de 
sobrevivência moral frente à exclusão. A ação de sobrevivência é menos político-revindicativa e mais simbólico-expressiva.

A ação política está sempre presente no movimento, mas como tensão. $\mathrm{O}$ exemplo mais patente disso são os intentos de Coordenação Metropolitana, que buscavam dar organicidade a partir de uma condução política, mas que nunca conseguiram a representatividade do movimento. Existia uma distância entre lideranças e bases; os primeiros, embora fossem a dimensão permanente do movimento, muitas vezes sobredimensionaram as oportunidades políticas abertas em 1983 e foram incapazes de conciliar as diferentes tendências presentes no movimento.

Por outra parte, os pobladores seriam um ator marcado pela heteronomia, ou seja, sua situação e ação apareceriam como objetos construídos a partir de fora por agentes externos. Quanto menos constituídos como categoria social estável, mais dificuldades teriam os pobladores para construírem por si próprios elementos precisos de autodefinição. Quando a base de autorreferência de qualquer movimento é fraca, mais vulnerável é a intervenção de agentes externos. Precisamente porque na ação dos pobladores não surge com clareza um princípio que os unifique, daí mais peso adquirem as racionalizações externas. A heteronomia é vista por Campero como um aspecto negativo, pois pode chegar a obstaculizar a conversão do Movimento de Pobladores num movimento social, ou seja, um movimento com autonomia e capacidade de transformação das relações sociais. A condição de heteronomia do movimento gera novas tensões, particularmente com os agentes organizadores externos que afirmam uma ideologia da independência dos grupos, ao mesmo tempo que se amplificam as dependências do movimento em relação à sua própria ação e aos recursos que estes agentes representam. Porém, para o autor, os agentes externos tiveram o mérito de servir de pontes entre a experiência pré-73 e o movimento durante a ditadura. $\mathrm{O}$ apoio externo teria sido mais acumulativo que inédito, pois teria dado continuidade 
ao investimento de promoção social anterior. Mesmo com enfoques e concepções diferentes, esses agentes beberiam da expertise institucional acumulada do período dos governos democrata-cristão e da Unidade Popular, continuidade que foi assegurada pela experiência militante de esquerda ou eclesiástica.

Estes antecedentes permitem que surjam rapidamente conexões e redes de relações entre a Igreja Católica, as instituições de promoção, os ativos políticos subsistentes e grupos de pobladores para enfrentar as consequências desorganizadoras da intervenção militar. Entre uns e outros existem experiências prévias, linguagens e metodologias mais ou menos compartilhadas que não obrigam a começar do zero. Tendo em conta o anterior se pode dizer que há um fio comunicante entre as tradições participativas que se desenvolveram na democracia e a situação posterior ao quebro de 1973, o que permitiu fazer uma ponte fundamental para recuperar uma capacidade básica de ação organizada entre os pobladores. Na construção desta ponte, o papel principal foi jogado pela Igreja Católica, em particular através da Vicaria da Solidariedade criada em 1976 e de suas outras agências de ação social. É muito provável que, por não ter mediado esta inversão, desde pelo menos uma década antes da queda do regime democrático, os efeitos desestruturadores sobre a organização poblacional tivessem sido maiores. Tem que se destacar o fato de que uma proporção importante (perto dos dois terços) das lideranças de organizações de base provinha de experiências de formação originadas antes de 1973, tinham vinculação com agências estatais ou privadas de promoção nessa mesma época ou excerceram responsabilidades nas Juntas de Vecinos, nos Centros de Madres e em outras instituições de participação social. Da mesma maneira, não poucos deles tiveram alguma militância política (CAMPERO, 1987a, pp. 56-7). 
Apesar do destaque que fez Campero deste âmbito de continuidade do Movimento de Pobladores, um dos tópicos mais trabalhados entre os cientistas sociais da época foi a tendência à descontinuidade. Os pobladores se visibilizavam por irrupções que não pareciam ter relação umas com outras (ESPINOZA, 1984). Aliás, essa foi uma das principais preocupações deste sociólogo, que, embora ao longo de sua trajetória buscasse encontrar nesses fragmentos uma tipologia da ação coletiva (ESPINOZA, 1998), foi também um dos autores que compartilhou o marco teórico que negava a condição teórica de movimento social aos pobladores. Porém, na prática, suas interpretações, inicialmente coincidentes com o grupo tourainiano - ele foi um dos pesquisadores de SUR que aplicou a metodologia de intervenção sociológica aos pobladores - se distanciarão da leitura do "antimovimento", e o autor se transformará em um dos referentes da leitura espacial que será revisitada na próxima seção.

Qual é a relação entre a política e os pobladores? - é uma das perguntas que move a reflexão do autor. Os protestos redefiniram a questão política nas poblaciones. Nos bairros populares, estava se fazendo política, o que se queria era derrubar a ditadura e seu sistema. De fato, "o impacto político da ação poblacional é notável, nem mais nem menos que uma mudança nas relações de forças em favor da oposição e contra o governo" (ESPINOZA, 1986, p. 36). Mas o desafio era passar do descontentamento à articulação com o sistema de representação política, dos gestos aos discursos e da condição de vítimas a de atores. Ou seja, como fazer para que sua ação política fosse mais instrumental, pois a agregação de reivindicações não constitui por si só uma proposta ou uma visão de totalidade. Porém, "ainda não é possível falar de 'movimento popular urbano' já que, embora tenha mostrado uma alta capacidade de questionamento à dominação, não é claro que isso desemboque numa mudança efetiva da situação presente" (ESPINOZA, 1986, p. 32). 
Contudo, os protestos são um fato urbano: as manifestações e a repressão concentram-se nas poblaciones. Elas são territórios tomados, delimitados com barricadas, fogatas, valas ou qualquer outro mecanismo para impedir o ingresso da repressão. Nos protestos, o que prima é antes a expressividade que a discursividade; há uma percepção da política como demonstração de força. A política se encontra em estado primário de confrontação de forças, a linguagem é a ação (as barricadas, as pedradas, os comícios etc.), o que prevalece é a espontaneidade, embora a convocatória seja centralizada. Porém, os protestos ao mesmo tempo produzem o efeito de isolar as poblaciones do resto da cidadania. Os pobladores não figuravam como atores para os outros movimentos (sindical), por isso, com o esforço de construção de coordenadoras metropolitanas, o que se buscava era sua validação e reconhecimento como atores.

Entretanto, para o sociólogo chileno, se trata de expressões mais ideológicas que de estruturas representativas, já que enquanto não adquirem representatividade será difícil falar de movimento de pobladores como tal. Por um lado, embora os partidos recrutem militantes nas poblaciones, os militantes, mais que pobladores politizados, são transmissores da política dos partidos nas poblaciones. Por outra parte, as organizações de subsistência, embora congreguem o maior número de pobladores organizados, são iniciativas geralmente atomizadas. A maior riqueza da atividade poblacional é ao mesmo tempo sua principal fraqueza: a enorme diversidade e heterogeneidade de organizações. Há praticamente uma organização para cada problema, o que dificulta a constituição de convocatórias comuns. Mas o que é interessante neste autor é que se, por um lado, adere à definição teórica dominante na época de movimento social, ele considerará que todos estes elementos mostram sua existência factual.

Definitivamente, é arriscado se referir aos pobladores como movimento nestas condições. Mas estão aí, se expressam e são um fato. 
Um ator em processo de constituição, com muitas limitações tanto de sua própria estrutura como das condições sociais nas que se desenvolvem. Mas se expressam e agem avassaladoramente, embora não saibam muito bem onde sua ação pode desembocar. Os elementos que temos entregado, contribuem a precisar um pouco mais o sentido das dinâmicas de politização e mostram que além da heterogeneidade que as caracteriza ou da dispersão que os acompanha, há uma quantidade de elementos que tendem a adquirir coerência e a conformar os pobladores não apenas como um ator legítimo, mas também como um movimento com capacidade de criação histórica (ESPINOZA, 1986, p. 51).

Embora a visão do antimovimento social à la Touraine tenha sido hegemônica entre sociólogos e cientistas políticos, não foi unânime nas ciências sociais. Particularmente desde a história, se levantaram vozes críticas a esta perspectiva. Nesse sentido, foi particularmente exemplar o debate produzido ao interior de SUR entre o historiador Gabriel Salazar e o grupo de autores tourainianos com a publicação, em 1990, do texto Violencia Política Popular en Las Grandes Alamedas, onde Salazar (2006) tentou desenvolver uma perspectiva histórico-popular a partir da violência do povo, ou seja, uma epistemologia histórica do "baixo povo", recuperando sua particularidade criativa enquanto ator. A pergunta do historiador chileno basicamente foi: como compreender as 22 jornadas de protesto popular organizadas contra Pinochet? Neles parecia evidente a emergência de um saber social que se relacionava com os brotos de violência popular anteriores na história social chilena, ou seja, uma constelação de "estouros" historicistas, uma explosão de raiva historicista eminentemente política, a qual foi entendida da seguinte maneira:

A política dos alienados ou marginalizados nasce ou renasce no momento preciso no qual eles iniciam por si e em si próprios a 
desalienação ou a desmarginalização. A desalienação e a libertação constituem, sem dúvida, o elemento central do 'poder histórico' de todos os tempos. A política popular, enquanto construção de poder social, não pode senão se iniciar nos sujeitos e nas associações de sujeitos, para, uma vez consolidado isso como 'movimento', ir à construção do Estado popular. A política como esfera autocontida e situada fora e por cima dos sujeitos sociais é um conceito modernista que, usualmente, faz referência ao sistema de dominação capitalista (hoje, neoliberal). A História Social e o trabalho de todas as ciências sociais afins, no sentido de estudar a realidade dos sujeitos e a potencialidade de suas redes associativas e culturais, não tem como alvo 'escapar da política' para ficar no mundo dos 'bárbaros', mas não escapar da realidade concreta dos sujeitos populares para construir desde essa realidade seu poder concreto e a verdadeira política (que é aquela onde efetivamente se exerce a soberania popular e cidadã) (SALAZAR, 2006, p. 22).

$\mathrm{O}$ autor define como sua principal tarefa intelectual a contribuição para a formação de uma "ciência popular" ou "paradigma cognitivo popular", baseado na memória coletiva, nas redes comunicacionais alternativas e na cultura derivada da autoconstrução de identidades marginais, como contraponto da "ciência oficial" (engajada com o neoliberalismo) e como resposta à crise do marxismo. Esta ciência popular partiria da experiência do povo e de formas orgânicas, como a Educação Popular e a atividade dos intelectuais das ONGs, e que encontra no movimento popular mobilizado contra a ditadura uma das suas principais expressões. Estamos frente a uma politização de baixo com possibilidades e capacidades para gerar um projeto alternativo de sociedade a partir de bases escassamente institucionalizadas, mas em movimento. Nos gérmens da democracia local, no jornalismo popular, nos teatros populares, paulatinamente foi se criando uma ciência e uma política popular autônoma. Essa ciência popular teria dois contrapontos obstaculi- 
zadores. Primeiro, a epistemologia dominante, a qual teria criado condições concretas para que o movimento popular chileno não pudesse formalizar adequadamente seu projeto social, ao defini-lo como um ator massivo e territorialmente inundante, mas estagnado, pré-moderno e sem estatura nacional. Segundo, a suplantação da esquerda, ou seja, as formas de intermediação do conflito social por projetos esquerdistas, dadas pelo profetismo popular criador de mitos propagandísticos (MIR) e o profetismo parlamentário de esquerda ou nacional-popular (PC e PS). Estas suplantações que pretendem tomar o lugar do verdadeiro ator popular transformariam sua epistemologia numa ciência reclusa que precisa ser libertada.

O movimento popular precisa de uma ciência que ilumine a cela estrutural, a ruptura do encerro e o caminho às 'grandes alamedas'. Que ordene lógica e eficientemente a raiva popular. Que planeje a longitudinal dos instintos. Que se centre, de um lado, na valorização categorial e metodológica das particularidades (ou diversidades ou fragmentações); e, de outro, na valorização das rupturas, projeções e processos. Uma ciência da dinâmica social de humanização, não apenas das normas de funcionamento de um sistema estabelecido de equilíbrio social (SALAZAR, 2006, p. 52).

A ditadura teria destruído as formas mais visíveis de protagonismo histórico do movimento popular (partidos, sindicatos, intelectualidade), porém não conseguiu fazer o mesmo com as condiçóes concretas sobre as que afloravam a classe popular e sua vocação historicista. O movimento popular, segundo o historiador, tinha um tecido com capacidade de autorregeneração, sua força latente estava intacta. Cada elemento da nova cultura popular criada em ditadura virava uma arma de luta e um elemento de ação subversiva contra o Estado. Cultivava-se uma predisposição ao protesto e à ação direta no mundo popular, especialmente en- 
tre os jovens. Foi com os pobladores que os protestos ganharam mais força, nas poblaciones os protestos receberam massividade e expressividade social. Existiria um subsolo vulcânico na paisagem política popular no qual se acumulam as condições para sua eruptividade, e a ciência estaria chamada a cumprir um papel central na racionalização dessas condições de irrupção.

Esta visão do popular radicalmente autônoma e instintiva chocava diretamente com as concepções defendidas pelo grupo tourainiano, pelo qual a confrontação intelectual foi inevitável. Em relação às críticas que seu livro recebeu deste grupo, o autor chileno assinalou que o trabalho crítico dos intelectuais que defenderam a transição pactuada à democracia, do qual seus detratores formavam parte, foi demonstrar que o ajuste estrutural realizado pela ditadura se correspondia com os processos de modernização globais, ou seja, eram quase inevitáveis. Com as mudanças na estrutura social, que descentralizavam o papel da classe operária, seria impossível a repetição das condições que levaram à formação de um movimento revolucionário, como o que existiu até 1973, e mostraram que toda forma de violência popular era inútil ou uma involução anômica, assim como inúteis também eram as interpretações do neocomunitarismo.

Esta crítica teve um contexto, implicou uma leitura, uma argumentação e um tom. O contexto era a transição pactuada à democracia (ano 1991), processo liderado então por intelectuais 'renovados' de FLACSO (era o caso de Tomás Moulian de então), de ILET (onde trabalhava Guillermo Campero) e SUR (onde operavam Eugenio Tironi, Javier Martínez e Carlos Vergara, artífices da transição, e este autor, crítico daquela), ao que se adicionava o interesse da Fundação Ford (que financiou o projeto) em saber até qual ponto o movimento popular chileno poderia optar pela violência e por um projeto socialista na conjuntura da transição (1987-91). Era evidente que os involucrados no processo da 
transição pactuada necessitavam destruir o que implicava o livro sobre a violência política popular (VPP em diante): seguir um caminho diferente a essa transição. Tratava-se da primeira colisão teórica e política entre o paradigma cognitivo 'renovado' e o do 'humanismo crítico' (SALAZAR, 2006, p. 17).

O papel intelectual de Alain Touraine e do grupo que aplicou suas teses aos movimentos chilenos não teria sido neutro na transição chilena. Segundo o historiador, as teses de Touraine permitiram à intelligentsia chilena pactuar a transição democrática prescindindo do movimento popular. Frente à crise vivida pela ditadura existiam duas saídas para o intelectual francês: o caos (jornadas de protesto irracionais) ou a ordem (adotando o modelo de modernização ocidental). Este último caminho foi o escolhido por esse grupo, mas ele implicava um acordo entre elites, tendo como custo a exclusão política da maior parte da sociedade. Logo, a crítica destes intelectuais contra o autor chileno era, para este último, uma crítica conservadora, pois buscava, em último termo, dar legitimidade teórica ao legado neoliberal de Pinochet. Numa publicação recente, Salazar (2013) traçará um paralelo entre o papel dos Chicago Boys, o grupo de economistas formados por Milton Friedman que aplicou a revolução neoliberal no Chile, com o destes intelectuais, os “Touraine boys", por seu papel na teorização legitimadora da transição pactuada à democracia, que implicou a conservação do legado econômico da ditadura.

O retorno de Durkheim e Parsons [via Touraine] era, pois, absolutamente necessário, lógico e inevitável para os que queriam assumir a constituição neoliberal (ilegítima) de 1980 como ponto de partida de uma nova 'ordem sistêmica', desta vez absolutamente congruente com o modelo neoliberal vigente no mercado globalizado desde começos da década de oitenta. A legitimação tardia do sistema imposto pelo terrorismo requeria que as 'elites diri- 
gentes' do país (ditadura militar e políticos-intelectuais dispostos a 'negociar') se associassem duramente ao empresariado transnacional para se alinhar à corrente da modernização post-fordista. Sem essa associação estratégica, existiria caos, não apenas para o movimento popular (essencialista), mas para o mesmo golpismo militar (pragmatista). Apenas a modernização externa poderia salvar a um e outro (e aos sociólogos sitêmicos). E isso deveria ser assim mesmo ao preço de que a 'salvação' incluísse apenas a 'um setor social' (minoritário), deixando fora, 'em empobrecimento massivo', os setores maioritários da população. É impossível não ver aqui a continuidade e funcionalidade da sociologia chilena neo-sistêmica (inspirada em Durkheim e Touraine) com a necessidade de perpetuação e legitimação das 'criações' impostas pelo terrorismo militar no Chile e, por sua vez, com o mercantilismo exacerbado do reluzente e hegemônico capital financeiro internacional. Deste modo, para uma perspectiva histórica já decantada, a ditadura de Pinochet foi solicitamente assessorada, na etapa de construção, pelos Friedman's Boys, e na etapa de transição e democratização pelos Touraine’s Boys. Os primeiros para consolidar o novo sistema como mercado interno e externo; os segundos, para legitimá-lo tardia, teórica e politicamente como 'sistema' neoliberal (aliás, 'a nova democracia') (SALAZAR, 2013, p. 57).

A contracrítica de Salazar tem o mérito de introduzir uma discussão fundamental para a compreensão de como as ciências sociais constroem teoricamente um objeto como os movimentos sociais. O debate intelectual que enfrentou o grupo de autores tourainianos e os "comunitaristas", sendo o próprio Salazar o autor mais radical desta última, está fortemente mediado pela conjuntura política da época. A polêmica sobre os pobladores continha de maneira embrionária as discussões sobre as condições nas quais se daria a transição democrática. É pertinente se perguntar, deste modo, se as perspectivas que negavam a condição de movimen- 
to social não eram acaso uma negação do papel potencialmente inconveniente dos pobladores na transição democrática. Efetivamente, a leitura dos movimentos sociais em chave democrática nos anos 1980 continha também a preocupação com que os movimentos sociais não fossem obstáculos à democratização que eles próprios teriam possibilitado (CALDERÓN, 1986). Por outra parte, não cabem dúvidas de que existia uma simbiose entre a leitura destes intelectuais com a tendência política que se identificou com a transição pactuada à democracia e que se impôs sobre as vertentes mobilizantes (principalmente representada pelo PC) que sobredimensionavam o papel político a ser jogado por esses movimentos. Porém, este processo, na visão de Salazar, aparece mais como uma conspiração intelectual de negação da historicidade popular do que como resultado das interações entre determinadas conjunturas políticas e acadêmicas.

É claro que a negação da condição de movimento social ao Movimento de Pobladores tem consequências políticas e sociais, sobretudo para o próprio movimento. Se as ciências sociais coproduzem os movimentos sociais, também podem contribuir a desconstruí-los. Porém, a perspectiva do historiador peca por um construtivismo extremo, sobredimensionando o papel das ciências sociais na derrota dos movimentos sociais na transição chilena. No prólogo da segunda edição de Violencia Politica Popular en Las Grandes Alamedas, dá a impressão de que a sorte da transição e dos movimentos sociais foi selada no lançamento do seu livro, quando foi foco das críticas dos intelectuais de FLACSO e de SUR. Salazar é um construtivista extremo ao atribuir também aos intelectuais um papel tão significativo na elaboração da "epistemologia popular", já que o potencial transformador não se ativa porque ainda não se consolidou uma ciência popular, devido a esta quase traição da intelectualidade.

Ao afirmar que o papel intelectual dos Touraine's boys foi a legitimação teórica do modelo de transição defendido pela Concer- 
tación de Partidos pela Democracia, coligação de centro esquerda que governou o país com o fim da ditadura, Salazar também confunde a trajetória político-intelectual de Eugenio Tironi com a de todo o grupo de pesquisadores que aplicaram as noções tourainianas de modernidade e de movimentos sociais. Efetivamente, Tironi foi um dos intelectuais mais destacados do grupo de antigos militantes do MAPU - partido de cristãos de esquerda que apoiou o governo Allende - que determinaram o signo da transição chilena, seja assumindo responsabilidades no executivo, seja como intelectuais orgânicos da Concertación ou como nexo entre o mundo privado e o público como lobbysta e assessor comunicacional de grandes corporações até hoje.

Por outra parte, Salazar também omite o que se definiu como "Renovação Socialista" no Chile - ou seja, a crítica moral à política, propondo uma renovação da política, fomentando os protagonismos populares sobre as vanguardas, privilegiando o movimento sobre o partido -, que foi um dos eixos fundamentais de sustento da Concertación, junto com ser uma das posturas políticas em simbiose com o movimentalismo dos anos 1980, assim como da Educação Popular (BAÑO, 1983b). Dessa maneira, uma das principais vertentes políticas que reconheceram a importância do protagonismo popular, ao mesmo tempo, foi indispensável para validar a transição democrática chilena.

Finalmente, Salazar atribui ao sujeito popular uma condição de dopados culturais pelo avesso, ou seja, eles são uma espécie de "emancipadores inconscientes". A capacidade emancipatória está presente como um magma vulcânico no mundo popular, prestes à erupção historicista. Com isso, concebe uma construção instintiva do poder popular distanciada de partidos e instituições. $\mathrm{O}$ território popular estaria adubado por moléculas dispersas de soberania do povo prestes a germinar, de modo a criar um movimento popular que se reencontra com sua historicidade autônoma na ação direta sem intermediadores. Com isso, o autor constrói uma 
versão idealizadora e essencialista do popular, que vem sendo criticada sistematicamente nos últimos anos dentro da historiografia (GREZ, 2005; LOYOLA, 2012), mas que nos anos 1980 já gerava questionamentos. Para Carlos Piña (1987), as interpretações sobre a identidade cultural das classes subalternas variavam entre a negação e a idealização. No caso desta última, o popular é definido como o potencial ou realmente oposto ou contestatório ao oficial, aquilo que contribui a criar um verdadeiro sujeito popular, e o que não entra nessa definição é visto como simples alienação. Porém, ele adverte que "será inútil se ilusionar com o resgate de alguma identidade cultural 'pura', sobrevivente nas catacumbas da resistência cultural, continuidade da solidez simbólica pré-hispânica e pré-capitalista: reedição de olhares saudosos do 'bom selvagem"” (PIÑA, 1987, p. 281). Para o autor (1987, p. 289), não existe uma essência cultural do povo, o popular é definível só por relação, já que "não existem apenas dois blocos culturais, um dominante e outro dominado, correspondente cada um deles às duas classes que estão constantemente em aberto confronto. Como tem se afirmado, as diferentes identidades culturais, mais ou menos diferenciadas, se constituem sobre as bases materiais de uma divisão de classes que não correspondem necessiamente a uma expressão delas”. O problema que provoca o essencialismo é que se transforma em normativo, ou seja, interpreta o presente e pretende orientar o futuro sobre a base de um olhar externo. Assim, o estudo do social e a análise política derivam numa crítica moral ou numa desilusão fatual.

É possível construir uma crítica à leitura negacionista dos movimentos sociais sem cair numa idealização do popular?

\section{O Movimento de Pobladores como construtor do espaço popular}

Como alternativa às leituras comunitarista e do anti-movimento social, paulatinamente vai se consolidar uma interpretação 
que outorgará à variável espaço um papel central na compreensão do Movimento de Pobladores. Sem dúvida, esta leitura respondia a uma insatisfação intelectual com as visões anteriores, mas não chegou a ser uma polêmica com confrontação direta, pois não se propunha a uma definição alternativa de movimento social, uma vez que tomava como um fato a existência do Movimento de Pobladores, destacando seu papel na construção de uma cidade democrática. A ação dos pobladores territorializaria a política, constituiria formas de poder local e permitiria contra-arrestar a tendência à segregação social das políticas urbanas da ditadura.

Alfredo Rodríguez (1983), arquiteto e urbanista ligado a SUR, será um dos pioneiros na recuperação da dimensão espacial e cotidiana da política da cidade. Para ele, existiria um desdobramento da democracia na vida diária e na apropriação do espaço urbano, não apenas como uma questão de carências, mas como tentativas de superação da dominação. Ainda mais se considerar que a ditadura tentou construir uma cidade da disciplina contra o caos, sob o princípio de que para conquistar uma cidade que conheceu a liberdade é preciso destruí-la. Para tanto, dispersaram e separaram a população, através da repressão e o mercado. A população foi segregada como forma de controle e modelação de uma cidade contrária ao que significou o auge do Movimento de Pobladores e do Estado desenvolvimentista anterior. Nesse contexto, a política urbana, o processo de regionalização e o de municipalização promovidos pelo regime respondiam a uma geopolítica militar que aparentemente aspirava à descentralização, mas que na prática fortalecia o poder central, fazendo mais eficientes os mecanismos de poder e de administração verticais. "Reordenando o espaço social da cidade, estabelecendo uma ordem vertical e, por outra parte, dispersando a população através do castigo e da repressão, se tentou reordenar o espaço social da cidade de maneira tal que fosse possível a apropriação individual, privada dos bens públicos". Almejava-se, pois, à criação de "um novo espaço urbano que elimi- 
nasse os sobressaltos, que revertesse o passado próximo de começos dos anos 1970" (RODRÍGUEZ, 1983, p. 26). Assim, os atores do “caos", principalmente os pobladores, deveriam ser desarticulados, dispersados e suprimidos. Há uma política sistemática de castigo a estes, sendo apenas uma de suas expressões a erradicação dos campamentos que se localizavam nas zonas mais abastadas da cidade. $\mathrm{O}$ espaço urbano é mercantilizado e se suprimem os espaços políticos de reivindicação (desaparece, entre outros, o papel político do $\mathrm{Mi}$ nistério da Habitação). Com uma cidade do mercado, o regime declara que não quer mais proletários, mas proprietários (SILVA, 2012) e termina por converter a habitação não mais num direito, mas numa mercadoria.

Como contrapartida, a cidade vira um campo de luta, um lugar e objeto de disputas, onde o Movimento de Pobladores joga um papel central. Ao habitar a cidade, ele se reproduz, mas ao mesmo tempo se transforma. Para Rodríguez (1989), a própria trajetória do Movimento de Pobladores mostrará que sua principal bandeira de luta, a habitação, foi muito mais que construir uma casa, foi construir parte da cidade: "isto supõe que o objeto de preocupação do movimento popular urbano não é apenas o acampamento, a población, mas a cidade como uma totalidade concreta. Supõe desenvolver não apenas respostas parciais, conjunturais, mas um projeto de futuro, do que queremos: novas formas de construir a cidade; de objetivá-la e significá-la; de produzi-la e apropriá-la; de fazê-la e vivê-la” (RODRÍGUEZ, 1983, p. 54).

Paralelamente, esta questão implica que o Movimento de Pobladores precisa de um enfoque global que abranja também as formas como se organiza o poder na cidade, tanto na sua dimensão política enquanto governo como na sua dimensão social como vida cotidiana. O Movimento de Pobladores deve, portanto, incorporar a perspectiva do poder local. O trabalho social nas poblaciones e a educação popular tiveram o mérito de valorizar o cotidiano, as relações pessoais, as pequenas redes, as capacidades próprias, em 
resumo, a criação de movimentos no espaço cotidiano. Assim, o movimento deixa de ser apenas a organização dos "sem casa", ganhando amplitude. Por outro lado, os protestos populares implicaram uma reconquista do espaço público, as diferentes formas do movimento confluíam e tomavam lugar na cidade, fomentando o sentido de territorialidade, e o espaço público é inundado de espaço cotidiano: "o que está na base das jornadas de protesto é um certo sentido da história como construção coletiva a partir de uma multiplicidade de pequenos atos simultâneos, quase anônimos, e que têm uma dimensão espacial". Sendo que "isto muda qualitativamente as formas de fazer política, outorgando a ela uma dimensão espacial, territorial e um caráter concreto" (RODRÍGUEZ, 1983, p. 70).

Com a democratização, a questão territorial poderia ganhar mais força ainda, na medida em que o desenvolvimento de governos locais democráticos poderia permitir a inserção das organizações poblacionales nas estruturas de representação institucional (ESPINOZA et al., 1986). Embora não seria garantido que o problema da exclusão fosse resolvido com a democracia, os governos locais ofereceriam uma possibilidade de representação e integração democrática em escala territorial. $\mathrm{O}$ município é visto potencialmente como um espaço de representação eventualmente adequado para o setor poblacional. A construção de institucionalidade desde a base não seria sinônimo de cooptação nesta perspectiva, sob a condição de que o governo municipal estabeleça critérios de desenvolvimento democrático e os pobladores assumam sua capacidade de gestão e negociação de maneira autônoma.

A experiência sob a ditadura tem levado a fortalecer, entre os pobladores, dinâmicas de defesa comunitária e de busca insurrecional. O elemento comum de ambas opções é sua desconfiança na institucionalidade representativa. Isto poderia se constituir como um obstáculo à conformação dos pobladores como atores 
sociais. Uma das possibilidades das organizações de pobladores de se constituir como atores sociais é o desenvolvimento de formas de representação institucional no nível de seus próprios territórios (ESPINOZA et al., 1986, p. 65).

Apesar de possuir uma tendência aparente à descontinuidade e à irrupção desconectada, a trajetória histórica dos pobladores permite defini-los como produtores do espaço urbano. Assim é como os compreende Vicente Espinoza num dos textos mais influentes sobre pobladores: Para una historia de los pobres de la ciu$\mathrm{dad}$, de 1988. Nesse texto, a despeito das tendências teóricas que negavam a condição de movimento social, o autor rastreará o movimento de pobladores no começo do século XX, vinculando manifestações tão díspares como as organizações de locatários, suas greves e as tomadas de terrenos etc. Dessa maneira, define a constituição do grupo social a partir de sua própria ação histórica, pela análise de conjunturas de eventos específicos de produção do espaço urbano que alteravam as pautas tradicionais de ordenamento institucional e territorial. Um elemento privilegiado nesta análise é a relação entre os pobladores e a institucionalidade política desde seu questionamento mais radical até sua incorporação a ela. Com efeito, mesmo nas manifestações mais radicais de ruptura, como as tomadas de terrenos, estava presente o papel intermediador de agentes institucionais: partidos, Igreja Católica, autoridades etc. Em suas palavras:

Nesta história, apesar da aparência anti-institucional das ações dos pobres urbanos, elas sempre expressaram a reclamação de integração ao sistema de decisões. Por isso a política esteve presente desde sempre na história dos pobladores. Certamente a motivação imediata era a resolução dos problemas de habitação; mas ao reconstruir a história fica em evidência que, para além de motivações individuais, há pautas recorrentes na ação coletiva. A 
principal delas, aliás, é a busca de participação institucional (ESPINOZA, 1988, p. 355).

É interessante destacar que a perspectiva defendida pelo autor está marcada por uma dupla ruptura; por um lado, com o grupo tourainiano do qual formou parte e, por outro, com a visão radicalmente autonomista de Gabriel Salazar. Espinoza não é negacionista, o movimento existe nos fatos históricos; nem é autonomista, o Movimento de Pobladores é influenciado pelo papel intermediador de agentes institucionais. Neste ponto, vale a pena destacar uma pesquisa que sem ser classificável como espacialista, enfatiza o papel dos partidos políticos de esquerda na construção do Movimento de Pobladores também numa chave de continuidade histórica. Trata-se do trabalho de Cathy Schneider (1995).

O movimento de protesto chileno de 1983-86, se não foi o precursor de um novo ator social, ou uma resposta imediata à crise econômica de 1982, foi mais que o produto de militantes políticos isolados que operavam fora das poblaciones marginais. Mais bem, a capacidade destes bairros urbanos para mobilizar uma resistência política massiva trás anos de severa repressão militar, radicava na herança política de décadas de trabalho na cultura popular e na formação de uma geração de militantes de base talentosos (SCHNEIDER, 1990, pp. 224-5).

Esta autora observará que os protestos não se distribuíram homogeneamente nos bairros pobres nem se concentraram nos setores mais atingidos pela crise econômica. Pelo contrário, o protesto ganhou mais força nos mesmos "bairros vermelhos" onde a esquerda tinha consolidado uma presença de longa data. Nesses bairros, a coesão social e a existência de uma disseminada rede de militantes permitiram que se mobilizasse uma resistência a grande escala, quando se produz a crise econômica de 1982. Porém, 
Os militantes políticos não tiveram iguais resultados. Aquelas poblaciones que tinham sido organizadas 'desde cima', ou seja, por militantes externos ao bairro, encontraram mais dificuldades para manter a resistência depois de 73 , em relação àquelas dirigidas 'desde baixo', onde os partidos políticos tinham estabelecido uma base orgânica. Esta diferença se pode ver claramente ao comparar as poblaciones que surgiram à raiz de tomadas de terreno ilegais dirigidas pelo MIR, e aquelas conduzidas pelo Partido Comunista (SCHNEIDER, 1990, p. 226).

Contrariamente ao que outros pesquisadores definiam como um "novo ator social", que se diferenciava da experiência dos anos 1970, pela sua constituição autônoma por sobre a influência partidária (OXHORN, 2004), para a autora a sobrevivência do Partido Comunista em algumas poblaciones foi consequência de um enfoque conducente à aparição de "intelectuais orgânicos" de base, a qual permitiu a renovação dos dirigentes presos ou assassinados. A base do sucesso desse partido teria sido a geração de uma cultura popular nos anos anteriores ao Golpe de Estado.

Bernarda Gallardo (1986), autora ligada institucionalmente à FLACSO e que compartilhou vários elementos da leitura comunitarista, também desenvolverá uma interpretação que atribui ao espaço-población a condição de lugar de pugna em relação à definição do ser social do poblador, ou seja, é a población que cria o poblador. Este espaço condiciona o comportamento e as consciências dos seus moradores no princípio da organização da cidade: ao mesmo tempo em que os pobladores não são objetos inertes da dominação, eles resistem e projetam sua alternativa, o que os define como sujeitos coletivos. Isso é o que permitiria descobrir a inteligibilidade do processo histórico que fez das poblaciones uma entidade socialmente significativa. Eis também o desafio teórico que representam os pobladores para as ciências sociais: 
O poblacional oferece um problema teórico-conceitual ainda pouco trabalhado. Socialmente aparece como possuindo uma realidade empírica indesmentível: existe uma materialidade poblacional (as poblaciones, os acampamentos), uma 'vida poblacional' (o conjunto de práticas e relações sociais que se desenvolvem na población e os sentidos culturais que as organizam); existe, por último, um grupo humano que socialmente é definido como 'pobladores' e que se reconhece como tal, que historicamente se transformou em sujeito de mobilização social e política (GALLARDO, 1986, p. 2).

Para ela, são as contradições que instala a atual cidade (moderna, industrial ou capitalista) com uma concepção do espaço como lugar e objeto de pugna social, o que outorga importância ao fenômeno poblacional e o que permite avançar na compreensão do conflito social que ele expressa. É a apropriação do espaço urbano o que compromete a definição mesma da identidade do poblador. Recuperando a tradição teórica representada por Henri Lefebvre (2010), Gallardo entenderá a especificidade do poblacional a partir da significação espacial que este fenômeno tem. A población é o primeiro elo de conexão com os problemas da cidade e da relação do espaço urbano com a dinâmica social. Com a ditadura, vai mudar o perfil do fenômeno poblacional, e este ganhará peso quantitativo (aumentará o número de pessoas morando em habitações precárias). As poblaciones começam a concentrar desempregados, a se deteriorar; por outra parte, o mecanismo da tomada de terrenos perde centralidade por causa da repressão, e os bairros populares começam a se fechar sobre si próprios - deixam de ser o espaço apenas de habitação e começam a ser um lugar de trabalho e sobrevivência. Politicamente, os pobladores ganham importância dentro da esquerda pela diminuição da classe operária e pela busca de novos sujeitos populares de transformação - a difusão da experiência do sandinismo nicaraguense é exemplo disso. 
Porém, as ciências sociais continuam com as análises estruturais do fenômeno poblacional, ou seja, o compreendem a partir da sua inserção no aparelho produtivo, mostrando resistência ao incorporar o territorial como variável explicativa do conflito que sustentam os pobladores. Nessas leituras, o espacial é rejeitado por esconder o caráter de classe do fenômeno, sem compreender a relação entre espaço e dominação. Segundo Gallardo, os bairros populares exemplificam a estruturação do espaço da cidade por parte do regime, os pobladores são definidos como inimigos internos e são segregados para distanciá-los dos centros de poder e para controlá-los, para o qual se promove sua atomização e a perda de sua identidade coletiva (via remoções). Porém, isso gera diferentes formas de resistência, pois o espaço é suscetível de contrapoder, mediante a apropriação e o estabelecimento de "territórios libertados" (como nos protestos). A questão chave para a autora é que o desmonte dos mecanismos que produzem a cidade segregadora é também o desmonte dos processos de reprodução do sistema socioeconômico da ditadura.

É assim como podem chegar a ser compreendidas teoricamente como lugar de pugna social. Lugar de uma pugna social em relação aos princípios de organização da convivência social e em relação à definição da identidade poblacional. Em termos genéricos, nos referimos à disputa pela definição do ser social dos pobladores, a qual pode ser entendida como oposição à ordem, na sua estratégia de reproduzi-los enquanto massa subordinada, e aos pobladores, na sua tentativa de superar essa situação de massa segregada, se constituindo em sujeito coletivo, ator de relações sociais alternativas (GALLARDO, 1986, p. 73).

A segregação promovida pelo regime gera o efeito inesperado de estimular a constituição de uma organicidade baseada no territorial, aparecem formas de solidariedade que cimentam o 
processo de constituição de uma identidade poblacional de caráter comunitário. A cidade segregada cria o germe de sua própria transformação.

O caráter segregativo da cidade é paradoxal, porque ao constituir as poblaciones como espaços urbanos homogêneos em termos de sua função e de suas funções, facilita a constituição de um sujeito poblacional coletivo. Neles os pobladores se encontram como iguais e como pertencendo a um mesmo todo; se descobrem como sujeito coletivo que comparte um mesmo presente de escassez e um destino comum. Referência territorial de sua identidade que é reforçada ou que se cimenta também no fato de que são controlados e vigiados pelo poder enquanto pobladores, enquanto moradores de um espaço urbano particular: as poblaciones e acampamentos populares. Referência territorial que também aparece no conceito de pobladores que nossa particular cultura nacional tem criado (GALLARDO, 1986, pp. 78-9).

Francisco Sabatini (1981) será particularmente enfático para criticar a tradição de estudos sobre a questão poblacional por não considerar a variável espaço. Nas suas pesquisas, em 1989, mostrará a existência de uma consciência fragmentada dos que participam das organizações poblacionales, assim como uma série de obstáculos à participação: as longas jornadas de trabalho, elementos da própria cultura popular (contraditória com uma consciência crítica), a preferência por relações com indivíduos (reciprocidade), problemas de liderança, a insegurança física etc. Mas, ao mesmo tempo, considerará indispensável a compreensão do movimento de pobladores não apenas pelo que é como também pelo que pode chegar a ser, tomando distância do que ele considera leituras excessivamente realistas que terminam por atribuir aos pobladores uma inclinação conformista. 
Valeria a pena perguntar pelo efeito concreto das publicações inspiradas por este 'realismo'. Estarão verdadeiramente ajudando aos que dedicam sua energia à ação orientada por objetivos de mudança? Não afirmo que a resposta seja necessariamente 'não'; mas valeria que se tivesse em conta esta inquietude. É preciso cuidar que os 'realismos', por excessivos e unilaterais, não virem uma profecia que se cumpre por si própria. Não me parece que encontremos saída à crise com 'realismo' demais (SABATINI, 1989, p. 65).

Para Sabatini (1990), é preciso ter cuidado também com as leituras "aprioristas" e "mecanicistas". As primeiras partem do suposto do caráter conservador, apático e desorganizado ou revolucionário, transformador e destruidor dos pobladores. $\mathrm{O}$ "mecanicismo", por sua vez, estabelece um vínculo direto e linear entre pobreza e mobilização social, descuidando o fato de que a constituição do movimento é também uma questão hermenêutica e subjetiva. A participação em organizações de sobrevivência, por exemplo, não se dá exclusivamente por razões econômicas. Os participantes delas não encontram formas que em realidade lhes permitam sua manutenção, o que explica que seu compromisso com elas sejam fatores extraeconômicos: estas organizações forneceriam uma "segurança ontológica" frente às condições de deterioração provocadas pela crise. Desta maneria,

Parece, em definitivo, inadequado discutir a priori se os pobladores são apáticos ou agentes propulsores de mudança, fazendo abstração da dinâmica que possa produzir, entre outros fatores, a busca de segurança. Em definitivo, talvez influenciados pelo positivismo (estudo sobre as coisas são separados do que deveriam ser) ou pela velha prática de transpor conclusões desde as ciências naturais [...], muitas análises tendem a reduzir os pobladores à natureza animal que todos temos. Os impulsaria à fome, à falta 
de habitação e outras necessidades fisiológicas cuja insatisfação acentuam determinados processos e contradições sociais. Seus comportamentos sociais e políticos poderiam se deduzir mecanicamente dessas realidades objetivas (SABATINI, 1990, p. 129).

Em geral, as diversas leituras que incorporaram a questão espacial ao fenômeno poblacional permitiram recuperar importantes elementos da trajetória do movimento, valorando positivamente sua contribuição à construção de uma cidade democrática e, ao mesmo tempo, outorgando um sustento teórico à importância política do Movimento de Pobladores para além da específica conjuntura da transição democrática. Embora não enfrentaram diretamente os desafios teóricos impostos pelas leituras tourainianas dominantes na época, permitiram uma renovação das temáticas e das referências em torno do Movimento de Pobladores. Questóes como a territorialidade, o poder local, a segregação, são temáticas que irão ganhando força e centralidade nos debates urbanos das duas décadas seguintes, outorgando a este grupo de autores a condição de pioneiros de uma temática que virará dominante posteriormente.

\section{Movimento de Pobladores, entre a novidade e a negação}

A produção acadêmica sobre o Movimento de Pobladores durante a década de 1980 foi ampla e extensa, marcando uma renovação significativa do campo de estudos da questão dos atores urbanos, incorporando novos autores e referências, sendo o mais destacado Alain Touraine. O desenvolvimento dos diferentes estudos sobre esse ator social foi importante também, porque, nas diferentes polêmicas e divergências, expressaram-se algumas tendências marcantes na construção teórica dos movimentos sociais. As diferentes leituras se debateram num vaivém entre o pessimismo e o otimismo em relação ao ator social estudado. Dependendo 
da conjuntura, passou-se de ênfases na novidade ou protagonismo do mundo poblacional a diagnósticos que mostravam sua ausência ou elaboraram laudos cadavéricos de um movimento que nem foi tão poderoso como se acreditava. Realmente existiram movimentos sociais de caráter urbano? Foram uma ilusão ou uma realidade transitória?

Mesmo na produção que negou a condição de movimento social ao Movimento de Pobladores, podem se encontrar elementos para afirmar sua existência. Embora o Movimento de Pobladores efetivamente não tenha definido os termos da transição democrática nem elaborado um projeto unificado de sociedade com normas novas, ele não apenas se mobilizou na ruptura contra a ditadura, contribuindo enormemente para sua desestabilização e para a aceleração dos processos de negociação para uma própria saída institucional, como também se mobilizou para votar massivamente contra Pinochet no plebiscito que pôs fim aos 17 anos de ditadura militar (a média de votação pelo "Não" a Pinochet foi maior nas poblaciones que no resto do país). Nesse percurso, os pobladores desenvolveram um riquíssimo repertório de ação coletiva, seja com as organizações de sobrevivência local, seja com as formas de resistência direta à repressão. Por que não considerar o que foi compreendido como diferentes lógicas de ação coletiva (comunitarismo, ação política etc.) ou diferentes projetos que disputaram a condução do movimento como elementos que enriqueceram o estoque de alternativas organizacionais do movimento, ao invés de eixos desarticuladores?

O que explica a oscilação entre o otimismo e o pessimismo acadêmico? O próprio Touraine considerava que parte importante das interpretações que exageravam o potencial político dos movimentos de pobres urbanos se explicava pela insatisfação de alguns intelectuais com as estratégias e formas de organização da esquerda tradicional. Os pobladores ofereciam um sujeito alternativo à classe operária para a realização das mudanças e, ao mesmo tempo, suas 
organizações pareciam mostrar lógicas radicalmente democráticas em relação aos antigos vanguardismos e verticalismos da esquerda. Nos bairros populares, construía-se e antecipava-se localmente a democracia que se esperava conquistar para o país. Resultaria lógico que em face às leituras tão iludidas se consolidassem visões desmistificadoras, mas empiricamente não é difícil demonstrar que as mudanças prometidas não estão sendo cumpridas na prática. Porém, qual é o sentido de negar teoricamente a condição de movimento social aos pobladores?

Sem dúvida, a conjuntura política permeou as análises das ciências sociais sobre os movimentos sociais. A derrota da opção mobilizante frente à alternativa de negociação institucional na oposição à ditadura teve influência nos posicionamentos que os intelectuais e cientistas fizeram sobre o fenômeno que estudavam. Porém, resulta difícil aceitar a explicação de Gabriel Salazar que identifica neste processo quase que uma confabulação intelectual para negar o Movimento de Pobladores para assim legitimar a transição democrática nos termos do pacto realizado pelas elites. A conjuntura política atinge as conjunturas intelectuais, ainda mais quando o que está em questão é o estudo de um sujeito potencialmente determinante na primeira. Contudo, na consolidação de determinadas hegemonias intelectuais, estão presentes elementos próprios da lógica científica que ajudam a explicar o papel preponderante do pensamento de Alain Touraine.

Segundo Geoffrey Pleyers (2006), Alain Touraine sempre se caracterizou por um compromisso com as trajetórias de ação coletiva na América Latina, mas, ao mesmo tempo, se negou a cumprir um papel de intelectual orgânico dos movimentos. Suas intervenções marcavam uma distância crítica frente aos atores sociais e políticos, sendo seu método de intervenção sociológica a prova disso. Porém, a rigidez dos seus pressupostos de compreensão do que é um movimento social impediu que ele encontrasse um sujeito que fosse capaz de ocupar o lugar do movimento operário na so- 
ciedade industrial, agora na sociedade programada. Alain Touraine é um cético das expressóes reais dos movimentos coletivos, mas porque cultiva uma definição idealizada de um sujeito social (ou movimento social) capaz de lidar com a historicidade de um modo tal que transforme as orientações fundamentais da sociedade.

Poderia se afirmar que tanto nas versões ineditistas (comunitaristas) como nas leituras negacionistas (o Movimento de Pobladores como anti-movimento social) o que está em jogo é uma idealização do sujeito de estudo. Os ineditistas, porque, a partir do comportamento do sujeito, atribuem uma série de potencialidades otimistas sobre seu papel na sociedade, e os negacionistas, porque partem de uma definição idealizada do que deveria ser um movimento social. Nos primeiros, há uma idealização indutiva, onde a prática é idealizada; nos segundos, uma idealização dedutiva, onde a idealizada é a definição teórica.

Agora, por que os pesquisadores que aplicaram ideias tourainianas ao estudo dos pobladores nunca questionaram uma definição teórica que não correspondia à realidade estudada? Até que ponto nas ciências sociais uma interpretação pode ser tão hegemônica que, mesmo quando empiricamente os fatos estão mostrando a existência de um movimento social, se persiste numa definição rígida e ambiciosa que desqualifica a expressão real do movimento?

As autoridades da ditadura militar não tiveram esses problemas teóricos; eles consideraram o Movimento de Pobladores como um movimento social extremamente perigoso para seus planos de aplicação e consolidação da revolução neoliberal em curso. Consequentemente, desenvolveram uma série de dispositivos repressivos elaborados especificamente para neutralizar os pobladores. Tal como mostra a pesquisa do Comité de Memoria Histórica José Domingo Cañas (2005), a ditadura transformou a población num campo de torturas e prisão política em si própria. Em cada protesto, os bairros populares sofriam intervenção militar, eram cercados, os homens eram retirados e obrigados a permanecerem duran- 
te horas de pé, seus pertences eram quebrados ou roubados e suas lideranças sequestradas ou presas. Mas, mesmo assim, a ditadura fracassou no seu intento de desarticular a organização poblacional. Os pobladores conseguiram se transformar num ator fundamental de oposição à ditadura, desafiando seu domínio e desafiando as definições de parte importante das ciências sociais. 


\section{Capítulo 6 \\ AnOS 1990, A DESCONTINUIDADE OU QUANDO \\ ANTIGOS ATORES SAEM DE CENA}

A década de 1990 marca um clima intelectual bastante diferente das décadas anteriores. Segundo Eduardo Devés (2004b), a questão da "identidade" será o centro do pensamento latino-americano dos anos 1990. Os movimentos sociais, embora não desapareçam como tópico de reflexão das agendas de pesquisa, agora aparecem transmutados como movimentos identitários. Se, por um lado, a resistência identitária frente à globalização será o grande eixo do pensamento continental, por outro, ganham centralidade temáticas, tais como: a democracia, a transição, a sociedade civil, a cidadania, a reforma do Estado, a governabilidade. Conhecidos atores sociais saem de cena e novas prioridades aparecem nas ciências sociais.

Nos anos oitenta e profundizada nos noventa, se produz uma diáspora no pensamento crítico latino-americano. A visão organicista e funcional sobre o caráter dos conflitos e crises societais é assumida como um referente válido. Novamente ordem e progresso. Governabilidade e paz social. Os apelos a manter as reformas neoliberais do Estado, os procesos de privatização, assim como os programas econômicos sobre pactos de exclusão fundamentados no mito do progresso nos fazem pensar na refundação do poder. Uma refundação totalitária e neo-oligárquica, na qual oferecer um projeto alternativo pode ser considerado subversivo e desarticulador do corpo social (ROITMAN ROSENMANN, 2000, p. 170). 


\section{Os pobladores nas margens da transição democrática}

No caso do Chile, o retorno à democracia não significou a abertura de novos canais de participação e de protagonismo para o movimento de pobladores. Com o fim da Ditadura Militar, se estabeleceu um pacto que tinha como condição de estabilidade a paulatina desmobilização das forças sociais que contribuíram para o fim do regime. Com isso, o Movimento de Pobladores praticamente desapareceu da cena política e da agenda de pesquisa de boa parte das ciências sociais, notadamente da sociologia e da ciência política.

Se, depois de realizado o golpe, as ciências sociais se perguntavam amargamente por onde estavam os pobladores radicalizados, de começos dos anos 1970, que tinham concentrado as esperaças de protagonizar uma mudança estrutural e eventualmente resistir às tentativas contra-revolucionárias da burguesia chilena, no início dos anos 1990, alguns pesquisadores reatualizavam o questionamento: aonde foram os pobres urbanos que se mobilizaram durante os anos 1980 contra a ditadura militar (OXHORN, 1994)?

Segundo Manuel Antonio Garretón (1987), apesar de que, com os protestos populares de 1983, a mobilização social tenha chegado a ocupar um lugar central na relação regime-oposição e nas definições estratégicas desta última, elas não foram suficientes para constituir atores sociais autônomos, nem para conseguir satisfazer as expectativas criadas em relação ao seu papel na transição. A "transição invisível”, o fenômeno de redemocratização da sociedade via reorganização dos atores sociais, não se traduziu numa "transição formal", pela manifesta incapacidade da mobilização popular de passar à ação política como sujeito coletivo autônomo. No final, a transição ficou em mãos de atores políticos enfrentados aos seus próprios problemas constitutivos. $\mathrm{O}$ regime militar não foi capaz de eliminar os atores sociais, mas estes também não foram capazes de derrubá-lo, deixando a transição "invisível” in- 
completa. Com a transição democrática se cumpria a profecia que negava a condição de movimento social aos pobladores?

Já a começos da década de 1990, o historiador Gonzalo Cáceres (1993) advertia sobre a dificuldade de que o "renascido" Movimento de Pobladores dos anos 1980 mantivesse o protagonismo alcançado durante a ditadura. Por um lado, porque as lógicas transicionais que privilegiaram a estabilidade se sustentavam numa baixa pressão setorial, sendo que as instâncias de coordenação metropolitana do movimento de pobladores eram incapazes de manter a convocatória e a unidade de outros momentos; por outro, porque a dinâmica do mercado imobiliário limitava o principal repertório de ação coletiva dos pobladores: a tomada de terrenos. Com a privatização do espaço urbano, escasseavam terrenos potenciais para serem ocupados. Por outra parte, uma vez instalada no governo, a Concertación iniciou uma das políticas habitacionais mais bem sucedidas em termos quantitativos na América Latina. Embora reduzisse significativamente o déficit habitacional, ao mesmo tempo, privilegiava uma solução institucional baseada na poupança familiar, que se apoiou em soluções de baixa qualidade, que descontinuaram as redes sociais dos pobladores, estimularam novas formas de marginalidade (gangues, drogas e violência) e terminaram por constituir bairros degradados (DUCCI, 1997). Em outras palavras, resolveu em grande medida o problema dos "sem teto" para criar um novo problema, desta vez dos "com teto" (RODRÍGUEZ e SUNGRAYES, 2006).

Vicente Espinoza (1993) salientará que este cenário adverso à ação coletiva dos pobladores poderia seduzir os cientistas sociais para um diagnóstico apressado que estabelecesse o definitivo fim do movimento. A descontinuidade da ação coletiva dos pobladores é, para ele, uma constante histórica que, portanto, deve ser considerada na própria definição do ator, assim como se deve considerar a posição do conflito urbano no contexto da ação coletiva, ao invés de reduzir os movimentos sociais à presença/ausência de 
conflitos. O Movimento de Pobladores não é apenas um agregado de mobilizações descontínuas. Para compreendê-lo, é preciso distinguir entre o "tempo curto" (conjunturas de irrupção ou ausência) e o "tempo longo" de caráter histórico. Se o analista fica com o "tempo curto" da conjuntura, tenderá a cair em leituras descontinuistas. Em contraposição, o "tempo longo" permitirá apreciar os elementos de continuidade do movimento social.

É precisamente com esse intuito que Espinoza (1998) retomará alguns dos elementos do seu trabalho de colaboração na equipe dirigida por François Dubet, propondo uma releitura do Movimento de Pobladores a partir de quatro eixos de ação coletiva: ação reivindicativa, participação institucional, ação comunitária e lógica de ruptura. Embora esta caracterização mostre alguns problemas ao misturar tipos ideais com tipos históricos (cada eixo de ação é característica de um período diferente do movimento), será útil para sustentar um ponto vital na concepção deste autor sobre os pobladores: a história dos pobladores indica que a ausência de conflito direto (irrupção) não é sinônimo de desaparição permanente do movimento. Aliás, o grande desafio do movimento com o retorno da democracia é sua integração política. Embora na figura da municipalidad exista um potencial de institucionalização das demandas, a eleição de militantes do movimento no aparelho municipal não resolve a questão, pelos riscos de burocratização implícitos. Porém, Espinoza (1993) não vê necessariamente o fim do Movimento de Pobladores, mas uma nova página na relação entre movimento e Estado, dada pela capacidade deste último de absorver de maneira mais eficiente e mais ampla as demandas dos pobres e pelo melhoramento da capacidade de negociação dos pobladores frente a este Estado mais responsivo. Espinoza (1994) chamará a atenção também para o fato de que grande parte do tecido social popular corresponde a processos microssociais de sobrevivência, introduzindo um novo fator de compreensão dos pobladores: as redes sociais. El pasaje, rua típica das poblaciones chilenas, será o 
espaço territorial privilegiado de compreensão dos processos de adaptação e integração social das famílias populares chilenas para enfrentar os desafios da sobrevivência cotidiana. Se as lideranças do movimento ignoram esse fato, aumentarão as chances de que continue se ampliando a distância com suas próprias bases. A principal tarefa do movimento, nesse sentido, é a passagem desde as ruas da población às "grandes Alamedas".

Ton Salman (1998) utilizará outra estratégia para superar as leituras desiludidas do Movimento de Pobladores, reconhecendo que as organizações populares não originaram massas de sujeitos críticos portadores de uma democratização renovadora. Ele enfatizará o caráter acumulativo e demorado da mudança social, incorporando algumas noções bourdieusianas a sua análise. Os atores são lentos e as mudanças reversíveis; aqueles não são corpos facilmente manipuláveis pelos processos sociais. Mais do que "homens novos", estamos frente a "homens lentos", determinados por seu habitus cultural. Uma sociologia da mudança deve incorporar uma dimensão de "continuidade" daquilo que resiste à mudança. A razão prática é estável e, por outro lado, muitas mudanças aparentemente rápidas e profundas carecem de durabilidade. Para o autor, é possível entender melhor os efeitos das mudanças que acontecem no contexto das mobilizações para ação coletiva com o habitus e com uma noção de cultura como possível freio, na medida em que nem sempre são atingidas pela intervenção política. Com isso, se evitariam o determinismo (desiludido) e a leitura de disposição à mudança (romanticismo). A mudança não se expressa de maneira imediata. Agora, embora deslocadas a um lugar secundário da democracia, as organizações do mundo popular não desapareceram. Um ator lento não é um ator inerte.

A década de 1990, do ponto de vista do campo de estudos do Movimento de Pobladores, ante a aparente ausência destes, estimulou a elaboração de revisões históricas da trajetória do movimento. O teólogo Maximiliano Salinas (1996) foi um dos autores 
que propôs uma das mais originais reinterpretações da trajetória dos pobladores, a partir de uma perspectiva religioso-popular. Para ele, os pobladores constituem uma sociedade particularmente religiosa que compreende sua própria história como uma passagem do profano ao sagrado, da morte à vida, do não ser ao ser. A partir dessa perspectiva, a luta dos pobladores adquire uma carga mística e pode ser concebida como uma luta pela preservação da sacralidade popular, na qual defendem seu mundo frente à discriminação econômica, social e cultural. Os pobladores afirmam e defendem seu modo de vida valorando a terra, conquistada com um evento ritual fundador, a tomada de terrenos. A terra é vista como um lugar sagrado, apesar de todas as profanações possíveis. Ela possuiria o peso simbólico da madre-terra como imagem magnânima que remete à origem rural dos pobladores, e que se encarna na figura da Virgem. Valores políticos e míticos se misturam nesta trajetória:

Os pobladores formam um mundo próprio composto de crenças, de costumes sociais e religiosos, de 'misturas' impraticáveis pela cultura dominante. Suas conviç̧ões religiosas de origem rural a respeito da Virgem, símbolo da 'Mãe Terra', foram colocados em relação com a adesão política ao Partido Comunista chileno, formando assim uma cosmogonia popular comum. Em 1965, o XIII Congresso deste partido reconheceu que os pobladores de Santiago, ao celebrarem as ocupações de terrenos, afirmavam que eles deviam esta vitória ao mesmo tempo ao Partido e à Virgem (SALINAS, 1996, p. 356).

Porém, será a história a disciplina que com maior determinação acolherá o Movimento de Pobladores entre seus tópicos prediletos. $\mathrm{O}$ relativo abandono da sociologia e da ciência política, com exceções (DÁVILA, 1994; SEPÚLVEDA, 1998), vai ser compensado por uma série de estudos historiográficos que, frente à ausência do sujeito no presente, buscarão no passado as evidências 
do seu protagonismo. Nesse sentido, a tese de doutorado de Mario Garcés (1999), posteriormente publicada sob o título de Tomando su sitio: el movimento de pobladores de Santiago, 1957-70 (2002), será o texto acadêmico mais importante deste período, exercendo uma influência determinante na formação de novos pesquisadores da área e na conformação de um campo de estudos específico. Para ele, o Movimento de Pobladores ocupa o mesmo patamar de importância que o movimento operário na história social chilena. Eles são os dois grandes atores sociais protagonistas do século XX. Este autor tinha realizado uma importante contribuição à sistematização da memória popular e à promoção da educação popular da direção da ONG Educación y Comunicación (ECO) (GARCÉS, 2010). Mas, já com anterioridade, outros historiadores tinham se dedicado sistematicamente ao estudo deste sujeito social, analisando seja sua trajetória geral (CÁCERES, 1993), seja sua fase de incorporação à vida política nacional (LOYOLA, 2006) ou estudando experiências específicas de organização popular (DE RAMÓN, 1990; FARÍAS, 1992; GÓMEZ LEYTON, 1994; PÉREZ, 1995). Nesse sentido, não se pode deixar de reconhecer a centralidade da figura do historiador Armando de Ramón (2007), quem, no Instituto de História da PUC-Chile, estimulou e orientou intelectualmente a maior parte desta nova geração de historiadores da questão poblacional.

O grande mérito da história foi servir como antídoto às leituras descontinuistas. Porém, embora crescessem as descrições de diferentes episódios da trajetória do Movimento de Pobladores, a discussão conceitual sobre movimentos sociais e sobre o estatuto dos pobladores ficou em dívida. Estes diferentes aportes permitiram superar o "provincianismo histórico" (MILLS, 1995) que apresentavam as leituras conjunturais baseadas, segundo a categoria de Espinoza, no "tempo curto" do Movimento de Pobladores, mas não se responsabilizaram pelos desafios teóricos deixados pelos autores de décadas anteriores. 
Embora a consolidação da história como principal disciplina de estudos dos pobladores nos anos 1990 possa ser considerada uma resposta à saída de cena destes da conjuntura política pós-ditadura, houve alguns acontecimentos que tematizaram esta ausência: a tomada de Peñalolén de 1992 e uma nova tomada realizada na mesma comuna em 1999 (SALAZAR, 2013). Ambas as experiências foram emblemáticas e tiveram marcada presença na mídia nacional, estimularam debates sobre a segregação residencial, sobre o problema habitacional e terminaram por se transformar no marco de inspiração de um "retorno dos pobladores" no Movimento de Pobladores en Lucha (MPL, 2011) como expressão de novas formas de subjetivação político-popular (ANGELCOS, 2010). Porém, sua repercussão na produção de textualidade acadêmica vai ser tardia, ganhando presença só na década seguinte, particularmente quando o conflito assume novos contornos pela proposta de realocação dos pobladores perto de uma Comunidade Ecológica de classe alta, enfrentando duas concepções de cidade e modos de vida (ALVAREZ ROJAS, 2008; CÁCERES, 2003; MARDONES, 2009; ROJAS, 2006). Obviamente este efeito tardio se deve a que a segunda tomada se realiza no final da década de 1990, mas o fato de que a primeira não tenha gerado uma produção mais significativa indica a ausência de uma conjuntura acadêmica favorável à recepção deste acontecimento, desaparecendo o sentido de urgência que outras vezes primou no campo no intuito de registrar e ponderar com rapidez uma determinada irrupção dos pobladores. Contudo, a realização dessas tomadas desmentiu a supostamente definitiva desaparição do Movimento de Pobladores, apesar de sua perda de protagonismo na década.

\section{Do movimento favelado à violência urbana}

No caso do Rio de Janeiro, as favelas não saíram da agenda de pesquisa das ciências sociais durante os anos 1990. Pelo con- 
trário, e tal como mostra a pesquisa de Lícia Valladares e Lidia Medeiros (2003), na qual fizeram uma quantificação analítica de todas as publicações sobre favelas cariocas entre 1906-2000, nesta década se produz uma explosão bibliográfica do tópico. Porém, a favela será protagonista nas ciências sociais não como um lócus de um potencial movimento social, e sim como espaço de intervenção pública (Programa Favela-Bairro) e como principal cenário da violência urbana. Nesse contexto, a ideia de uma "cidade partida" (VENTURA, 1995), sustentada na divisão favela-asfalto, ganhará força explicativa para compreender as dinâmicas urbanas cariocas (CARVALHO, 1993).

As favelas cariocas voltam a ser tema de reflexão sociológica nos anos 1990 na medida em que expressam fenômenos novos, para além da mera 'pobreza' em termos de renda. Sua nova dinâmica aponta para uma sociedade 'fraturada', na qual as leis universais não são efetivamente para todos e a identidade do pobre enquanto 'trabalhador' confunde-se com a do 'bandido'. Nesse contexto a autoridade do crime organizado ganha espaço e legitimidade nas favelas, ao mesmo tempo em que decresce a experiência histórica de luta das associações de moradores e seus ideais políticos. As políticas do Estado para as favelas, voltadas quase que exclusivamente para a repressão e controle do narcotráfico parecem conduzir a um obscurecimento das verdadeiras questões subjacentes à nova dinâmica social das favelas: as da exclusão social moderna e da globalização e suas consequências sociais e políticas (FAUSTO NETO, 1995, p. 417).

A emergência da "violência urbana" como um novo entendimento das ameaças à estabilidade das rotinas cotidianas, com novos significados associados ao crime comum e a novas expectativas e temores em torno da atividade policial rotineira (SILVA, 2012 b), configuraram uma força de gravidade ineludível para as 
ciências sociais, na medida em que ganhou centralidade nas preocupações da sociedade carioca (PAIXÃO, 1990). A consolidação de gangues de traficantes de drogas pesadas, a utilização das favelas como centros de operações dessa atividade e como espaços de disputa entre traficantes, segundo Machado, configuraram um cenário paradoxal, pois, se por um lado, com o início da transição democrática, se reduziram os níveis de violência política como nunca antes na história brasileira, por outro, ocorreu uma escalada da violência na vida diária, que desafiava o processo de democratização e punha o controle social rotineiro no centro da agenda pública.

Já na década de 1980, pesquisas que tinham por objetivo a compreensão das organizações populares ou os significados da pobreza, comprovavam que esse exercício não se podia realizar sem, ao mesmo tempo, incorporar à análise a violência, seja do tráfico armado, seja da polícia, sobre a população favelada (ZALUAR, 1985). Não deixa de ser sintomático que numa das suas análises críticas sobre movimentos sociais no grupo de trabalho da ANPOCS consagrado a este tópico, Machado da Silva (1990, p. 18) tenha afirmado que "seria possível dizer que a violência urbana corresponde, para o campo temático dos movimentos sociais, ao 'outro lado da Lua' - aquele que não pode ser visto, mas existe e é parte do que se vê".

Seja para estudar os processos de urbanização em curso nas favelas (BASTOS e GOMES, 1993) ou para analisar as dinâmicas de lazer (DECCACHE-MAIA, 1999) os pesquisadores se encontrarão com a robusta presença da violência urbana e do tráfico de drogas como um poder paralelo na favela (LEEDS, 1998). Será preciso, portanto, compreender como o crime atinge as dinâmicas da favela, assim como a cultura da violência e as consequências da presença do tráfico armado para a organização social (ZALUAR, 1990, 1998). A violência urbana nas favelas ganha autonomia como campo de estudos e começa a ser compreendida como dota- 
da de uma lógica própria com independência de outros problemas sociais ou como uma forma de sociabilidade específica (SILVA, 1999).

"Pasárgada", nome com o qual Boaventura Santos (1989) batizou a favela na qual realizou o campo de sua tese de doutorado numa alusão utopista a um poema de Manuel Bandeira, deixava de ser um lugar quase mítico, onde as classes oprimidas criavam um direito "informal" como estratégia de sobrevivência perante a legalidade formal hostil através das Associações de Moradores. Agora, passa a ser o lócus de uma judicialidade fundamentada na violência exercida pelo crime organizado do tráfico de drogas, acentuando os processos de atomização social das favelas: "Pasárgada é mais o fruto do imaginário sobre a América Latina construído durante a década de sessenta nos países centrais, do que a situação típica das nossas favelas, que se caracterizam não por laços comunitários, mas pela atomização que reflecte a lógica de cada ator normativo" (JUNQUEIRA e RODRIGUES, 1992, p. 16).

Este pessimismo acadêmico terá sustento no fato de que a emergência da violência urbana deixou a população favelada entre o fogo cruzado de traficantes e policiais, transformando-se no principal obstáculo para a organização popular. Segundo diferentes depoimentos de militantes de favelas (PANDOLFI e GRYNSZPAN, 2003), as associações de moradores sofreram intervenções, em muitos casos, de traficantes, designando chapas favoráveis aos seus interesses, e até algumas lideranças foram executadas por traficantes ou policiais sob a acusação de colaboração com uns ou com outros; as facções do tráfico impediram a livre circulação entre favelas, assim como limitaram a liberdade de expressão dentro das comunidades. Ante este cenário que dificultava as possibilidades de representação das favelas, a ausência de antigos aliados (Igreja) e frente ao esvaziamento da base social e legitimidade das Associações de Moradores (LEITE, 2008), muitos militantes tiveram que buscar novas formas de participação. Nesse momento, a figura das ONGs será funda- 
mental para oferecer a esses militantes um espaço de participação e práxis política. As ONGs permitiram que muitos militantes não abandonassem o território e continuassem o disputando, através de uma reinvenção do papel da liderança comunitária, mas restringindo sua ação a um âmbito mais restrito e sem vocação de representatividade.

A reinvenção dos militantes de favelas e a aparição de novas organizações de familiares de vítimas da violência urbana são indícios de que a organicidade favelada, mesmo muito golpeada, não desapareceu nesta década. Aliás, a relação entre movimentos sociais e institucionalidade mostrará que, apesar de tudo, os "novos" atores da década de 1980 deixaram sua marca na jovem democracia brasileira. Segundo Ana Amélia da Silva (1994), os movimentos sociais fizeram uma importante contribuição para a formação de uma nova contratualidade urbana, baseada numa política habitacional que privilegiava a população de baixa renda, enunciando novos direitos e participando na gestão da coisa pública (Câmaras Setoriais, Políticas Públicas Participativas etc.) para além dos conflitos ligados ao trabalho. Os movimentos sociais, em geral, conseguiram institucionalizar a representação dos seus interesses, assim como participar em diferentes canais de negociação. Mas, mesmo tendo deixado sua marca em novas políticas urbanas, no Rio de Janeiro se experimentará um ocaso da principal instância de organização das favelas, as Associações de Moradores. Porém, isso não será sinônimo do fim das organizações com base territorial nas favelas.

A favela, apesar da constante atualização do mito das "classes perigosas”, das tentativas de remoção (MAGALHÃES, 2013) e das mais variadas estigmatizações, conseguiu se afirmar no espaço urbano carioca como uma fonte enormemente criativa de expressões culturais e formas de organização (CECCHETTO, 1998; OLIVEIRA e MARCIER, 1998; SANTOS, 1998a). Ao avaliar o século de existência de favelas no Rio de Janeiro, Alba Zaluar e 
Marcos Alvito chegaram à conclusão de que "a favela venceu", mas foi um triunfo precário e constantemente ameaçado:

Não se pode deixar de sublinhar também a capacidade de luta dos favelados na defesa do seu local e estilo de moradia. Após 100 anos de luta, empregando diferentes formas de organização e demanda política, inclusive o carnaval, a favela venceu. Há menos de duas décadas, mudou a legislação, e hoje a favela é feita de habitações de alvenaria [...]. Ninguém fala mais de remoção. Mais recentemente, os projetos de urbanização e saneamento, fruto de pequenas vitórias acumuladas do movimento de favelados, fazem surgir ruas e praças... [Porém] hoje a favela enfrenta novos e terríveis problemas, em face do terror imposto tanto pela polícia, na repressão ao tráfico, quanto pelos próprios traficantes, cada vez mais afastados da população local. Além disso, novos conflitos surgiram e ameaçam aquilo que fez da favela um espaço propício à organização e à criação cultural, livre dos constrangimentos da crença incontestada, do maniqueísmo e da intolerância religiosos. Irá a favela desparecer? (ZALUAR e ALVITO, 1998, p. 21).

A favela venceu, mas o que aconteceu com os favelados e suas organizações? Segundo Machado (2002), a vitória da favela ocorreu à custa da constituição de uma categoria social subalterna que não mudou sua posição nem na sociabilidade urbana, nem na estratificação, assim como não mudou seu papel como força social. Sua expressão política se deu sob um "controle negociado", os agentes externos (Estado, classes dominantes) desistiram da imposição de uma solução unilateral de cima para baixo e os favelados e suas associações utilizaram cada fissura política em proveito dos seus interesses. Nesse percurso, os favelados conseguiram, com muitas dificuldades, se constituir como um ator político, muito mais modestamente do que as ciências sociais esperavam, mas deixando sua marca na vida urbana carioca. 


\section{Capítulo 7}

CONSIDERAÇÕES FINAIS: REPENSAR OS MOVIMENTOS PARA REPENSAR AS CIÊNCIAS SOCIAIS

Durante o século XX, tanto o Movimento de Pobladores quanto o Movimento de Favelados representaram um permanente desafio compreensivo para as ciências sociais. Se, por um lado, estas últimas contribuíram para o reconhecimento da importância política da mobilização popular urbana, por outro, os movimentos urbanos constantemente desbordaram os moldes analíticos nos quais os tentaram enquadrar. Contudo, as compreensões dos movimentos de pobladores e favelados oscilaram entre a novidade e o réquiem dos mesmos, enquanto ambos experimentavam processos de adaptação e metamorfose frente às novas situações sociais que deviam enfrentar.

A revisão crítica da literatura do século $\mathrm{XX}$ sobre movimentos urbanos, que foi aqui apresentada, mostra a necessidade de pensar a ação coletiva dos pobres das cidades da América Latina superando algumas das tensões e dicotomias cultivadas pelas diferentes escolas de interpretação da questão social urbana na América Latina. Repensar os movimentos para além da oposição entre free-riders e os marginalizados radicais parece ser uma das primeiras leituras a serem superadas. As diversas formas de construir demandas urbanas por parte dos setores populares respondem mais à possibilidade de utilizarem uma determinada forma de pressão ou de organização dependendo da situação social na qual se encontrem, as quais estarão sujeitas ao desenvolvimento 
de um determinado processo político-social. A reivindicação privatista ou a radicalidade não são atributos (essências) dos atores, nem os elementos constitutivos de uma determinada identidade social apriorística, mas variações de um repertório estratégico que se ativará dependendo de conjunturas favoráveis ou restritivas a um determinado tipo de ação coletiva. E, nesse processo, os pobres das cidades vêm mostrando bastante habilidade para saber quando usar uma forma ou outra.

Os elementos expostos também justificam a necessidade de repensar o Movimento de Pobladores e de favelados para além das oscilações teóricas das ciências sociais sobre movimentos sociais que reproduziram um ciclo analítico de redescobrimento, réquiem e negação. Embora seja impossível mapear a trajetória de ambos os movimentos sem a revisão ampla (e ao mesmo tempo crítica) da literatura que tentou compreender este movimento social (ou justificar sua inexistência), a tarefa parece ser sua superação.

Particularmente no Chile, apesar da riqueza da produção bibliográfica sobre o tema, a tendência foi acompanhar as descontinuidades dos próprios ciclos de mobilização dos movimentos de pobres urbanos. As elaborações teóricas e as pesquisas foram mais profusas nos momentos de alça ou de irrupção dos movimentos, enquanto nos períodos de recolhimento dos mesmos o tópico do urbano-popular tendeu a sair das agendas de pesquisa dos cientistas sociais. Como repensar a questão da descontinuidade dos movimentos urbanos?

Por outra parte, existem tensões que atravessaram os diferentes debates aqui revisados que podem iluminar novos caminhos de compreensão de pobladores e favelados como atores sociais e do papel das ciências sociais nesse exercício. A questão da autonomia/heteronomia dos movimentos, a espontaneidade/institucionalização, a expressividade-ruptura/estabilidade-negociação e a ameaça/promessa são dicotomias que devem ser repensadas para também reconsiderar o papel das ciências 
sociais na coprodução dos movimentos estudados. A segunda parte deste apartado pretende entregar algumas luzes sobre estes desafios.

\section{Temporalidade e espaço nos movimentos urbanos}

Do ponto de vista da compreensão conceitual da questão continuidade/descontinuidade dos movimentos populares urbanos, um exercício que pode ser frutífero é a incorporação ao debate de algumas noções da Teoria dos Processos Políticos, ou melhor dito, da sua versão mais recente, o programa do Contentious Politics (MCADAM et al., 2009). Não no sentido de substituir uma determinada teoria por outra, pois umas das reservas necessárias frente a estes autores, particularmente nos trabalhos mais atuais, é a amplitude de sua definição de movimento social, o que os têm levado a expandir seus interesses de pesquisa a toda forma de contestação política descuidando os próprios movimentos sociais. É notável constatar que enquanto a definição de Alain Touraine restringia de sobremaneira as experiências que poderiam entrar na sua definição de movimento social, no caso de Tarrow, Tilly e companhia, os movimentos sociais se diluem nas ações coletivas de confrontação política. Não tem muito sentido o que alguns autores (GARCÉS, 2012) vêm realizando ao reduzir o debate teórico dos movimentos sociais ao cumprimento dos critérios que esses autores definem como sendo parte de um movimento tal, pois quase tudo pode entrar na definição. A questão é a incorporação crítica e seletiva de algumas categorias que podem ser úteis para superar a leitura da descontinuidade desses movimentos.

Sob esta lógica, o movimento social é uma forma de ação complexa, não um ator nem um grupo, pelo qual não experimentam histórias naturais como os indivíduos (formação, florescimento, mudança e desaparição) (TILLY, 1995). A contestação política acontece quando oportunidades e restrições políticas criam 
incentivos para que atores sociais, que não possuem mais recursos que a ação coletiva, atuem desafiando com um repertório determinado às autoridades e a grupos poderosos (TARROW, 2009). Apesar do viés estrutural da sua proposta (GOODWIN e JASPER, 1999), eles chegam a uma categoria especialmente útil para compreender a trajetória dos movimentos sociais, a saber, o conceito de ciclos de mobilização:

Entendo 'ciclo de confronto' como uma fase de conflito acentuado que atravessa um sistema social: com uma rápida difusão de ação coletiva de setores mais mobilizados para outros menos mobilizados; com um ritmo rápido de inovação nas formas de confronto; com a criação de quadros interpretativos de ação coletiva, novos ou transformados; com uma combinação de participação organizada e não organizada: e com sequências de fluxos intensificados de informação e de interação entre os desafiantes e as autoridades. Esse confronto tão disseminado produz externalidades que dão aos desafiantes ao menos uma vantagem temporária e permite que superem a fraqueza na sua base de recursos. Ele exige que o Estado monte amplas estratégias de reação que são ou repressivas ou facilitadoras, ou uma combinação de ambas. E ele produz resultados gerais que são mais do que a soma dos resultados de um agregado de eventos desconectado (TARROW, 2009, p. 182).

A categoria de ciclos de mobilização enfatiza a condição processual da mobilização, e não pode ser vista como eventos isolados uns dos outros. Assim, momentos de auge (ondas de mobilização) e momentos de crise (fim repressivo de um movimento) formam parte de uma mesma trajetória que deve ser compreendida integralmente. Em particular, esta categoria resulta útil para superar as leituras deprimentes que surgem quando um ciclo de mobilização culmina em repressão e o que foram ondas de contestação derivam 
numa desilusão. Como diria Aristide Zolberg "Post coitum omnia animal triste" (apud TARROW, 2009, p. 183).

Porém, se esta perspectiva tem o mérito de transformar a história e o tempo em mais que simples contextos para os movimentos sociais, apesar de alguns esforços tardios (TILLY, 2000), a questão da espacialização dos movimentos sociais continua sendo um grande desafio para esta teoria (BRINGEL, 2011, 2012). Mas a questão do espaço vem sendo incorporada sistematicamente pela geografia crítica (HARVEY, 2008; SANTOS, 2008) nos debates mais recentes dos movimentos sociais, principalmente pela recuperação do legado de Henri Lefebvre (2010) e pelo protagonismo que vem adquirindo o conceito de "direito à cidade" nos movimentos urbanos (BURGOS, 2012; SABATINI e WORMALD, 2004). Nesse sentido, na definição do movimento social como uma categoria geográfica, está presente um grande potencial de enriquecimento conceitual e ampliação do diálogo interdisciplinário para a compreensão desses movimentos.

A expressão movimento social ganha, assim, para a nossa compreensão das identidades coletivas um sentido geográfico muito preciso: é que o vemos como aquele processo através do qual um determinado segmento social recusa o lugar que, numa determinada circunstância espaço-temporal, outros segmentos sociais melhor situados no espaço social pelos capitais (Bourdieu) que já dispõem tentam lhe impor e, rompendo a inércia relativa em que se encontravam, se mobilizam movimentando-se em busca de afirmação das qualidades que acreditam justificarem sua existência [...] Assim o movimento (social) é, rigorosamente, mudança de lugar (social) sempre indicando que aqueles que se movimentam estão recusando o lugar que lhes estava reservado numa determinada ordem de significações (PORTO-GONÇALVES, 1999, p. 69). 
Tanto o Movimento de Pobladores quanto o de Favelados têm sido e podem continuar sendo compreendidos como lutas territoriais eminentemente políticas, embora não seja uma política das grandes avenidas, mas sim uma dos becos dos bairros populares. Afirmar isto vai contra aqueles autores que reduzem a luta dos pobres urbanos à conquista de uma casa. A história desses movimentos, tal como afirmavam os pobladores chilenos nos anos 1970, mostra que é "uma luta maior que uma casa", pois as formas de territorialidade que promovem suas diferentes organizações, a saber, a conformação de espaços populares empoderados no contexto de cidades excludentes, implicam uma disputa direta com o mercado ou com o Estado pela capacidade de decidir sobre o urbano. A luta desses movimentos é, portanto, um exercício de soberania. Por isso, é possível definir os pobladores e favelados como construtores populares da cidade, que é outra forma de chamar o fato de decidir sobre suas próprias vidas: por exemplo, quando os pobres urbanos resolvem permanecer num lugar, enquanto o mercado, aliado ao poder público, já definiram sua expulsão para as margens da cidade.

\section{Velhos/novos desafios para a compreensão dos movimentos de pobladores e favelados}

Enquanto o Movimento de Pobladores santiaguino se organizou em torno da conquista da casa, sendo a Tomada de Terrenos a principal forma de ação coletiva, o Movimento de Favelados se constituiu em torno à defesa do direito de permanecer num território já conquistado em base à invasão "espontânea" dos morros cariocas, sendo suas principais bandeiras a "urbanização" e a luta contra as "remoções" desses territórios.

Uma leitura superficial desse dado poderia levar a justificar erroneamente que esta diferença de origem determinaria uma trajetória autônoma e radical entre os pobladores de Santiago e uma 
subordinada e clientelista entre as associações de favelados cariocas. Porém, tais trajetórias não existiram na prática e seria equivocado considerá-las como tipos ideais de ação coletiva. Assim como muitas das associaçóes cariocas de favelados foram criadas por iniciativa do governo do Estado, o que teria limitado seu potencial de resistência, em Santiago, muitas Juntas de Vecinos de pobladores nasceram no marco da lei homônima aprovada pelo governo democrata-cristão de Eduardo Frei Montalva. Aliás, boa parte das tomadas de terrenos do período de maior mobilização foram dirigidas ou incentivadas por partidos políticos incluindo a Democracia Cristã. Este paralelo não é menor, pois exemplifica um elemento que ganha ou perde peso dependendo das interpretações que dominam o campo de estudos da questão urbana num determinado período.

Não existe um antagonismo insuperável entre o movimento social e o Estado. Embora sua relação estivesse cheia de tensões e contradições e o Estado sempre tenha sido o principal alvo das demandas da ação coletiva urbana, na prática, na sua obrigatória interação, mudou o Estado e mudaram os movimentos sociais. Não se deve compreender este tipo de movimento social como uma instância alheia à questão institucional, como espaços de pura espontaneidade, onde qualquer tipo de negociação necessariamente descaracterizará a condição autônoma do movimento, embora possam existir tentativas públicas de intervenção ou controle estatal. Uma negociação entre movimentos e Estado não é sinônimo de abdicação do popular. Essa interação não precisa ser entendida sempre como uma colonização burocrática do social, pois em muitos casos também pode significar uma colonização do social no institucional. A expressividade da ruptura/espontaneidade e a estabilidade dada pelas diferentes formas de institucionalização e negociação dos movimentos são dimensões presentes nos seus diferentes ciclos, independentemente do peso que cada uma dessas dimensões possa adquirir nas diversas conjunturas políticas. 
A leitura de pobladores e favelados como um novo sujeito revolucionário ou como uma massa de manobra à disposição de projetos populistas responde em boa medida às próprias conjunturas acadêmicas que determinam que uma interpretação seja dominante ou não. As versões otimistas que atribuíam aos pobres urbanos um papel quase emancipatório estavam em simbiose com determinados posicionamentos políticos que buscavam substituir outras visões dentro do campo da esquerda e dos movimentos sociais. Na leitura da passividade, também esse fenômeno está presente, mas de outra maneira, por meio da interpretação de que os pobres urbanos reproduzem os vícios de uma classe operária que não possui "consciência para si" e prefere ser ator passivo de projetos populistas.

Por outro lado, o otimismo interpretativo está relacionado com o que poderia ser entendido como a urgência do presente. Quando a consecução de fatos sociais desafia não apenas as ciências sociais, mas também a ordem social, ou pelo menos quando atores e cientistas acreditam que determinadas ações fazem de uma potencial mudança algo possível, os cientistas sociais se jogam no campo em busca do registro e compreensão do fenômeno com um sentido de urgência tal que pode chegar a comprometer as conclusões de suas pesquisas. Quando um ciclo de mobilização se inicia, é alto o risco de que os pesquisadores superestimem os efeitos da ação coletiva de determinados atores. Este aumento de expectativas transformadoras, por sua vez, pode levar, posteriormente, quando o ciclo inicia sua fase descendente, a que os cientistas subestimem os resultados que ele trouxe. No primeiro caso, o cientista social parece se conceber a si próprio como o profeta do novo e, no segundo, como o coveiro dessa falsa promessa.

Agora, se a urgência por compreender uma sociedade e um ator que parecem experimentar ou propiciar grandes mudanças num intervalo muito curto de tempo pode explicar parte do modo de agir ou pensar dos cientistas sobre um ator social, não se deve 
desconhecer o fato de que o estudo de um determinado movimento social, mesmo com distanciamento temporal, também pode ser marcado por mistificações. Assim como quando a recuperação da memória de um movimento é usada para legitimar um grupo que se sente herdeiro desse passado ou quando uma determinada leitura consagra uma interpretação negativista da ação social de um movimento no passado para fortalecer uma alternativa ou uma crítica a um descendente direto desse movimento social.

Mas, em que medida a mudança social deve ser o parâmetro de avaliação de um movimento social? Como no caso das análises de Alain Touraine e seus intérpretes latino-americanos, se medimos o êxito ou mesmo a existência de um movimento social por sua capacidade de mudar a sociedade, seja sob a forma de uma revolução política ou cultural, estaremos condenando à intranscendência a maior parte das ações coletivas que podem ser incluídas dentro dessa categoria. A mudança social evidentemente é uma dimensão da vida dos movimentos sociais, porém sua concreção é altamente improvável, pelo qual não se pode julgar um movimento por um objetivo que, embora possa estar inscrito nas motivações de sua ação, dificilmente se concretizará. Um movimento social derrotado não deixa de ser um movimento social por isso. Porém, embora não se deva medi-lo por sua capacidade de fazer ou não a revolução, não se pode deixar de concebê-lo também na sua virtualidade, ou seja, no seu potencial para atualizar mudanças sociais, políticas ou culturais. É um equilíbrio complicado, mas não por isso deve deixar de ser um componente da pesquisa dos movimentos sociais.

Mesmo na definição de Touraine, o que parece estar em jogo é uma propensão das ciências sociais à idealização dos movimentos de pobres urbanos. A definição dos movimentos sociais realizadas pelo intelectual francês estabelece um critério de pertencimento tão restritivo que dificulta enormemente a tarefa de inclusão de alguma experiência de ação coletiva nessa categoria. Estabelece-se assim uma idealização teórica do que deve ser um movimento social 
que termina por desqualificar as expressões reais dos movimentos. $\mathrm{O}$ conceito começa a ser mais importante que a própria realidade.

A definição dos movimentos sociais como movimentos autônomos também é uma forma de idealização muitas vezes defendida pelos cientistas sociais. Porém, acadêmicos e intelectuais estão longe de ser os guardiões da autonomia, apesar de suas declarações de boas intenções. Primeiro, porque não existem movimentos sociais puramente autônomos. Pelo menos no âmbito urbano aqui estudado, favelados e pobladores construíram seus movimentos com a colaboração, e às vezes o obstáculo, de partidos, igrejas, intelectuais e outros movimentos. Segundo, porque muitas vezes a prédica da autonomia esconde um projeto político, geralmente não declarado, dos próprios cientistas. A relação intelectual/movimento já supõe uma forma de heteronomia. Mas isto não quer dizer que necessariamente esta relação esteja determinada por uma forma de manipulação. $\mathrm{O}$ intelectual pode não apenas ser visto como um aliado, mas também como um instrumento. Sua presença pode servir para legitimar determinadas lideranças, pode mediar o acesso a recursos de difícil acesso (imprensa, projetos, financiamentos etc.), e também o acadêmico pode virar um "intelectual orgânico" do movimento, contribuindo à complexificação discursiva na mesma medida que o movimento se complexifica.

É possível destacar o papel intermediador de agentes externos sem tirar protagonismo do movimento social? A afirmação da heteronomia dos movimentos sociais não implica supor que estes sejam o instrumento passivo de uma manipulação externa. Os movimentos sociais se produzem a si próprios, mas em interação com outros atores. Mesmo a presença de agentes externos nas barriadas pode ser considerada como um indicador da centralidade política do conflito popular urbano e até como uma forma de amplificação de sua repercussão. Os partidos podem contribuir à politização, à passagem do particular ao geral, mas também à dispersão 
e fragmentação desse conflito. A Igreja contribuiu com diversas ênfases a respaldar a organicidade dos movimentos populares, mas também criou formas de controle. As ciências sociais, dependendo das conjunturas político-acadêmicas, têm (des)legitimado teoricamente o estatuto dos movimentos sociais enquanto tais.

Sem dúvida, a concepção dos diferentes movimentos como ameaça ou promessa teve uma importante contribuição para o reconhecimento político, positivo ou negativo, do Movimento de Pobladores e de Favelados. Porém, o intelectual pode ser um obstáculo também, suas posições não necessariamente vão se alinhar com os interesses imediatos do movimento, suas omissões seletivas podem criar uma ideia distorcida do movimento ou até ele pode ser visto como o representante de interesses opostos. Isto leva a que muitas vezes o intelectual seja visto com desconfiança, como um aliado dos poderosos ou como um oportunista que busca tirar proveito das experiências populares para progredir no mundo acadêmico e depois abandonar o grupo.

Porém, os intelectuais contribuem à construção de uma memória histórica dos movimentos sociais. Sistematizando suas experiências, discursos e manifestações, sem dúvida aportam para que os movimentos sociais tenham maior consciência sobre sua própria trajetória. Parte importante da formação política das novas gerações de lideranças comunitárias se sustenta, quando a distância geracional dissolve a influência da experiência direta, em parte da produção acadêmica, sobretudo a historiográfica. Muitas vezes a história se incorpora a uma luta atual como um aliado. Por exemplo, o Movimento de Pobladores chileno, apesar de suas metamorfoses, seguirá reivindicando a memória da Tomada de Terrenos de La Población La Victoria ou do acampamento Nueva La Habana (COFRÉ, 2007). E os novos militantes das organizações de favelas eventualmente poderão recuperar a experiência de resistência do Borel para remarcar que existe uma história de lutas que se estende até hoje (FIELL, 2011). Porém, o ineditismo que 
em alguns períodos prima nas ciências sociais pode levar a deformar a imagem que eles têm de si próprios, no sentido de que "todo passado foi melhor", o que, no pior dos casos, pode redundar num imobilismo ou pode levar a uma concepção descontínua da trajetória do movimento que omite períodos significativos, mas menos visíveis, de sua conformação histórica (momentos de refluxo).

Contudo, parece evidente que as ciências sociais contribuem significativamente à autorreflexibilidade do campo popular, embora não necessariamente no sentido proposto por Touraine que aspira a uma "conversão" do movimento a partir do diagnóstico acadêmico. Mas, para o argumento aqui defendido, a questão também é em que medida a experiência do Movimento de Pobladores e de Favelados pode contribuir à autorreflexibilidade das próprias ciências sociais.

Tal como foi visto, nas leituras ineditistas ou em chave de novidade dos movimentos estudados está presente uma estratégia de legitimação acadêmica e, ao mesmo tempo, uma resonância do entrecruzamento de conjunturas políticas e intelectuais. Além do mais, as mistificações das ciências sociais que saem ao encontro de um movimento social puro e autêntico, terminam por virar a principal matéria-prima das teorias negacionistas do potencial político dos atores populares. Agora, o reconhecimento das continuidades nos movimentos, como forma de resposta ao ineditismo, não deve ser sinônimo de desconhecimento da criatividade dos atores sociais em cada período histórico. A superestimação realizada por uma interpretação cria o risco de uma subestimação como réplica, como aconteceu com a crítica carioca aos Movimentos Sociais Urbanos. No fim, a ciência social sobrerreage nas duas direções (otimismo-pessimismo) ante o desafio dos movimentos sociais de base territorial e caráter popular. Ambas são formas de miopia intelectual. Os otimistas olham tão longe que terminam por visualizar uma realidade que não existe e os céticos olham à distância, mas através dos óculos dos otimistas, 
distorcendo também o real e negando o potencial presente nesses movimentos. A avaliação se faz sobre a expectativa criada pelas próprias ciências sociais e não sobre a realidade mesma.

Uma matéria pendente neste sentido é um aprofundamento da reflexão sobre o papel do intelectual no estudo dos movimentos sociais. Com isto não me refiro a, uma vez mais, polemizar em torno do binômio compromisso/neutralidade do pesquisador. A questão, neste caso, não é redefinir as noções de pesquisa-ação ou pesquisa-militante para a mudança social e como forma de descolonização das ciências sociais (STAVENHAGEN, 1971), nem separar águas entre autores e instituições comprometidas e aquelas que têm por finalidade desmobilizar politicamente os setores urbano-populares e transmitir a ideologia dos setores dominantes (RODRÍGUEZ et al., 1972). O assunto é problematizar o papel do pesquisador no desenvolvimento dos movimentos sociais, especificamente como coprodutores deles. O intelectual comprometido nem sempre está alinhado com os posicionamentos dos atores estudados, nem aqueles que poderiam ser classificados como não comprometidos com um projeto de transformação social necessariamente deixam de estar identificados com o destino dos sujeitos de sua pesquisa. O ponto é ter maior claridade sobre as consequências que as disputas do campo intelectual podem ter para os movimentos sociais, ainda mais se considerar que ambas as esferas não são alheias ao sistema político e, sobretudo, às disputas da esquerda. Como as ciências sociais podem melhorar sua autoconsciência da performatividade do seu fazer científico?

A afirmação de que não existe neutralidade nas ciências sociais, embora pareça banal, precisa ser constantemente lembrada. $\mathrm{Na}$ seleção dos problemas de pesquisa e em alguns dos conceitos nela empregados estão implícitos valores que afetam o curso do razoamento e que precisam ser explicitados. Tal como assinalava o sociólogo norte-americano C. Wright Mills (1995, pp. 95-6), no seu clássico $A$ imaginação Sociológica: "Queira ou não, ou saiba ou 
não, todo aquele que emprega sua vida no estudo da sociedade e em publicar seus resultados, está atuando moralmente e, em geral, politicamente também. A questão está em que ou se encara esta situação e acomoda sua mentalidade a ela, ou se a oculta a si próprio e aos outros e vai moralmente à deriva". Daí a consciência que o pesquisador deve ter da importância ideológica de sua condição de cientista social, não apenas porque seus estudos podem ser empregados de diversas maneiras, como pela carga ideológica que o pesquisar em si porta. Wright Mills emprega o notável exemplo dos teóricos que na primeira metade do século XX divulgaram uma série de noções de "atraso cultural", das quais as teorias da marginalidade são herdeiras. Esse atraso se estabelecia em relação a uma ideia de progresso que continha boa parte do universo normativo e cultural da classe média norte-americana da qual os pesquisadores eram membros, valores que também faziam parte da ideologia liberal sustentada por essa mesma classe.

Da mesma maneira, é preciso fazer prevenções frente àqueles cientistas que pretendem se consolidar como os intérpretes autorizados de um movimento social autenticamente autônomo ou espontâneo. Obviamente um pesquisador-militante pode chegar a se situar como porta-voz oficial de um movimento popular, mas a questão é se perguntar se realmente existe algo assim como um "intérprete verdadeiro" ou um "movimento social autêntico" ou se são formas de mistificação estratégicas que pretendem consolidar a hegemonia de uma visão por sobre outras dentro do próprio campo popular e intelectual. Os movimentos sociais podem precisar das ciências sociais como forma sistemática de compreensão da realidade social e não como uma nova profecia ou como um espaço de celebração apologética de tudo aquilo que provenha da ação popular.

$\mathrm{O}$ auge, durante o século $\mathrm{XX}$, de movimentos como o de pobladores ou o de favelados está relacionado com o processo de expansão urbana na América Latina. Cidades que nascem e cres- 
cem a um ritmo acelerado, que atraem migrantes que ocupam e disputam os espaços disponíveis. Era de se esperar que, passado esse processo e iniciada a maduração urbana, as lutas, tal como se expressaram anteriormente, perdessem centralidade e magnitude ou ganhassem novos contornos. Esses tipos de lutas não voltarão, mas isso não significa que atores populares como os pobladores e os favelados saiam definitivamente do mapa político e acadêmico: a cidade continua sendo um espaço de disputa, e as lutas destes atores continuam mudando e assumindo novas formas. No Rio de Janeiro, a realização de megaeventos esportivos e a implementação das Unidades de Polícia Pacificadora nas favelas vêm criando uma nova conjuntura urbana, na qual se pretende impor uma visão de cidade excludente e privatista, mas que teve como efeito inesperado a consolidação de um grande número de formas de contestação que vêm revitalizando lógicas de organizações populares e outorgando nova centralidade à questão urbana (MAGALHĀES, 2013; MARICATO et al., 2013). No Chile, a aparição do que se entende na prática como um "novo" Movimento de Pobladores vem concentrando a atenção de um grupo significativo de jovens pesquisadores, ativando um processo de incipiente renovação do campo de estudos do poblacional pela aparição de novos movimentos, como o Movimento de Pobladores em Luta (MPL), o que vem marcando um retorno do poblacional pelo ressurgimento de formas de resistência e afirmação do direito à cidade pelos atores populares.

Em que medida os novos esforços de compreensão da questão social urbana na América Latina reproduzirão as virtudes e defeitos de um campo de estudos que ao longo do século XX se mostrou extremamente produtivo e controvertido? Ou em que medida as novas leituras superarão as disjunções otimistas/pessimistas sem cair em mistificações, réquiens ou ineditismos? Sem dúvida, parece cada vez mais necessário repensar o Movimento de Pobladores e de Favelados à luz das novas experiências de ação co- 
letiva e dos novos debates intelectuais que estas trazem. Mas este exercício não se poderá fazer sem, ao mesmo tempo, repensar as próprias ciências sociais e seu papel na (co)produção teórica desses movimentos sociais. 


\section{REFERÊNCIAS}

ALVAREZ ROJAS, A. M. "La segmentación socioeconómica del espacio: la comunidad ecológica y la toma de Peñalolén”. EURE (Santiago), v. 34, n. 101, pp. 121-36, 2008.

ANGELCOS, N. "La estructuración de la subjetividad popular y el problema de la política”. Revista de Psicología, v. 19, n. 2, p. 55-78, ago. 2010.

BANCK, G. e DOIMO, A. M. "Between utopia and strategy: a case study of a Brazilian urban social movement". In SCHURMAN, F. e VAN NAERSSEN, T. (eds.). Urban Social Movements in the Third World. London: Routledge, 1989, pp. 125-50.

BAÑO, R. "La relación poblacional sindical (si acaso) en la situación actual (régimen autoritario 1982)”. Programa FLACSO, n. 175, pp. 1-83, abr. $1983 \mathrm{a}$.

. "El Movimiento Popular Urbano en la perspectiva de las tendencias políticas”. Programa FLACSO, n. 196, pp. 1-75, nov. 1983 b.

. Lo social y lo politico, un dilema clave del movimiento popular. Santiago: FLACSO, 1985.

et al. "Dominación urbana y proyecto alternativo en América Latina”. Programa FLACSO, n. 114, pp. 1-138, jun. 1981.

BARRÍA, J. Historia de la CUT. Santiago de Chile: Prensa Latinoamericana, 1971a.

. El movimiento obrero en Chile: sintesis histórico-social. Santiago de Chile: Ediciones Universidad Técnica del Estado, 1971b.

BASTÍAS, A. e BENAVIDES, L. "La rebeldía primitiva de los hambrientos”. Nueva Sociedad, n. 82, pp. 1-13, mar. 1986. 
BASTOS, M. D. F. e GOMES, M. de F. C. M. "Impasse na urbanização de favelas - um estudo de caso". Cadernos IPPUR, v. 7, n. 3, pp. 45-58, 1993.

BEIGEL, F. Misión Santiago: el mundo académico jesuita y los inicios de la cooperación internacional católica. Santiago: LOM, 2011.

- “Centros y periferias en la circulación internacional del conocimiento”. Nueva Sociedad, n. 245, pp. 110-23, 2013.

BERLINCK, M. Marginalidade social e relações de classes em São Paulo. Rio de Janeiro: Vozes, 1975.

BLANCO, A. "Política, modernización y desarrollo: una revisión de la recepción de Talcott Parsons en la obra de Gino Germani”. Estudios Sociológicos, v. XXI, n. 003, pp. 667-99, 2003.

BLAY, E. A. "Mulheres e Movimentos Sociais Urbanos no Brasil: anistia, custo de vida e creches". Encontros com a civilização brasileira, v. 26, pp. 63-70, 1980.

BOMBART, J. P. "Les cultes protestants dans une favela de Rio de Janeiro. América Latina, v. 12, n. 3, pp. 137-59, jul. 1969.

BORJA, J. Movimientos Sociales Urbanos. Buenos Aires: SIAP-Planteos, 1975.

BOSCHI, R. Movimentos Coletivo Urbanos. Rio de Janeiro: Zahar, 1983.

e GOLDSCHMIDT, R. Participação e integração: um estudo sobre o comportamento politico do favelado. IUPERJ, 1970, pp. 1-25.

e VALLADARES, L. do P. "Movimentos associativos de camadas populares urbanas: análise comparativa de seis casos”. In (ed.).

Movimentos coletivos no Brasil urbano. Rio de Janeiro: Zahar, 1983, pp. 103-43.

BOSI, A. "Economia e humanismo". Estudos Avançados, v. 26, n. 75, pp. 249-66, 2012.

BOURDIEU, P. Intelectuales, politica y poder. Buenos Aires: Eudeba, 1999.

. "A ilusão biográfica". In FERREIRA, M. de M. e AMADO, J. (eds.). Usos \& abusos da história oral. Rio de Janeiro: FGV, 2006, pp. 183-91. 
BRANT, V. C. "Da resistência aos movimentos sociais: a emergência das classes populares em São Paulo”. In SINGER, P. e (eds.). São Paulo: o povo em movimento. Rio de Janeiro: Vozes-CEBRAP, 1982, pp. 9-27.

BRINGEL, B. "A busca de uma nova agenda de pesquisa sobre os movimentos sociais e o confronto político: diálogos com Sidney Tarrow”. Política \& Sociedade, v. 10, n. 18, pp. 51-73, 2011.

- “Com, contra e para além de Charles Tilly: mudanças teóricas no estudo das ações coletivas e dos movimentos sociais". Sociologia \& Antropologia, v. 02, n. 03, pp. 43-67, jun. 2012.

BURGOS, M. B. "Dos parques proletários ao Favela-Bairro: as políticas públicas nas favelas do Rio de Janeiro”. In ZALUAR, A. e ALVITO, M. (eds.). Um século de favelas. Rio de Janeiro: FGV, 2004, pp. 25-60.

. "Favela: uma forma de luta pelo direito à cidade". In MELLO, M. A. da S. et al. (eds.). Favelas cariocas: ontem e hoje. Rio de Janeiro: Garamond, 2012, pp. 373-91.

CÁCERES, G. "El Movimiento de Pobladores de Santiago, 1930-90”. El mensajero: boletin del Programa de Educación Popular - CIDE, n. 55, pp. 1-16, 1993.

. "La resolución de la toma de Peñalolén, ¿un ejemplo de cambio en las políticas habitacionales-urbanas?”. Revista CIS, v. 2, n. 3, pp. 9-13, 2003.

CALDEIRA, T. A Política dos outros: o cotidiano dos moradores da periferia e o que pensam do poder e dos poderosos. São Paulo: Brasiliense, 1984.

CALDERÓN, F. (ed.). Los movimientos sociales ante la crisis. Buenos Aires: UNU-CLACSO-IISUNAM, 1986.

CÂMARA, D. H. Esclarecimentos prestados por D. Helder Camara à Exma. Câmara dos Deputados a propósito do projeto 749/A. Rio de Janeiro.

CAMARGO, C. F. de et al. "Comunidades eclesiais de base”. In SINGER, P. e BRANT, V. C. (eds.). São Paulo: o povo em movimento. Rio de Janeiro: Vozes-CEBRAP, 1982, pp. 59-81. 
CAMPERO, G. "Luchas y movilizaciones sociales en la crisis: ¿se constituyen movimientos sociales en Chile?: una introducción al debate". In: (ed.). Los movimientos sociales y la lucha democrática en Chile. Santiago: ILET, 1986, pp. 9-19.

. "Organizaciones de Pobladores bajo el régimen militar". Proposiciones, v. 14, pp. 85-93, 1987a.

. Entre la sobrevivencia y la acción politica: las organizaciones de pobladores en Santiago. Santiago: ILET, 1987b.

CANCINO, H. Chile: Iglesia y Dictadura 1973-89. Un estudio sobre el rol politico de la Iglesia Católica con el régimen militar. Denmark: Odense University Press, 1997.

CARDOSO, A. A Construção da sociedade do trabalho no Brasil: uma investigação sobre a persistência secular das desigualdades. Rio de Janeiro: FGV, 2010a.

. "Uma utopia brasileira: Vargas e a construção do estado de bemestar numa sociedade estruturalmente desigual". Dados, v. 53, n. 4, pp. 775-819, $2010 \mathrm{~b}$.

CARDOSO, F. H. "Proletariado no Brasil: situação e comportamento social”. Revista Brasiliense, n. 41, pp. 98-122, maio 1962.

- "Comentarios sobre los conceptos de sobrepoblación relativa y marginalidad”. In NUN, J. (ed.). Marginalidad y Exclusión Social. Buenos Aires: FCE, 1970, pp. 141-83.

et al. "Consideraciones sobre el desarrollo de Sao Paulo: cultura y participación”. EURE, v. 1, n. 3, pp. 34-68, 1971.

e FALETTO, E. Dependencia y Desarrollo en América Latina: Ensayo de Interpretación Sociológica. Buenos Aires: Siglo XXI, 2003.

CARDOSO, R. C. L. "Movimentos sociais na América Latina”. Revista Brasileira de Ciências Sociais, v. 1, n. 3, pp. 27-37, 1987.

CARVALHO, C. P. de (ed.). Favelas e as organizaçôes comunitárias. Petrópolis: Vozes, 1993. 
CARVALHO, E. G. O negócio da Terra: a questão fundiária e a Justiça. Rio de Janeiro: UFRJ Editora, 1991.

CASASCO, J. "The social function of the slum in Latin America: some positive aspects". América Latina, v. 12, n. 3, pp. 87-111, jul. 1969.

CASTEL, R. Las metamorfosis de la cuestión social: una crónica del salariado. Buenos Aires: Paidós, 2004.

CASTELAIN, C. «Histoire du Campamento Nueva Habana: Chili 197173». Espaces et Société, n. 15, pp. 117-131, 1975.

CASTELLS, M. "Chile: movimiento de pobladores y lucha de clases". VIEXPO. Santiago, 1972.

. Luttes urbaines et pouvoir politique. Paris: Maspero, 1973a.

- Imperialismo y urbanización en América Latina. Barcelona: Gustavo Gili, 1973b.

. Cidade, democracia e socialismo: a experiência das associações de vizinhos de Madri. Rio de Janeiro: Paz e Terra, 1980.

. La ciudad y las masas: sociología de los movimientos sociales urbanos. Madrid: Alianza Editorial, 1986.

. La questión urbana. México: Siglo Veintiuno Editores, 2008.

CASTRO, P. "Indício na teia da mobilização popular urbana: o caso de Acari”. In BOSCHI, R. (ed.). Movimentos coletivos no Brasil urbano. Rio de Janeiro: Zahar, 1983, pp. 75-102.

CECCHETTO, F. R. "Galeras funk cariocas: os bailes e a constituição do ethos guerreiro”. In ZALUAR, A. e ALVITO, M. (eds.). Um século de favela. Rio de Janeiro: FGV, 1998, pp. 145-66.

CEPAL. El Desarrollo Social de América Latina en la Postguerra. Buenos Aires: CEPAL, 1963.

CHATEAU, J. “Algunos antecedentes sobre la situación de los pobladores en el Gran Santiago". Programa FLACSO, n. 115, pp. 1-42, jun. 1981.

CIDU. "Reivindicación urbana y lucha política: los campamentos de pobladores en Santiago de Chile”. EURE, v. 2, n. 6, pp. 55-82, nov. 1972. 
COFRÉ, B. Campamento Nueva La Habana. Concepción: Ediciones Escaparate, 2007.

COLliER, R. e COLLIER, D. Shaping the political arena. Princeton: Princeton University Press, 1991.

COMITÉ DE MEMORIA HISTÓRICA. Tortura en poblaciones del Gran Santiago (1973-1990). Santiago: Corporación José Domingo Cañas, 2005.

CORTÉS, A. "Los comunistas y la toma de terrenos de La Victoria: a 50 años de una de las tomas más grandes de Latinoamérica”. Alternativa, n. 25, pp. 92-101, maio 2008.

"Modernización, dependencia y marginalidad: itinerario conceptual de la sociología latinoamericana”. Sociologias, v. 14, n. 29, pp. 214-38, jan. 2012.

. "El movimiento de pobladores chilenos y la población La Victoria: ejemplaridad, movimientos sociales y el derecho a la ciudad". EURE (Santiago), v. 40, n. 119, pp. 239-60, jan. 2014.

CUNHA, F. S. "Movimentos Sociais Urbanos e a democratização: a experiência do movimento favelado de Belo Horizonte". Novos Estudos CEBRAP, n. 35, pp. 133-43, 1993.

DAS, V. e POOLE, D. "El estado y sus márgenes. Etnografías comparadas". Cuadernos de Antropología Social, n. 27, pp. 19-52, jul. 2008.

DÁVILA, O. "Acción colectiva y asociatividad poblacional". Última Década, n. 2, 1994.

DE RAMÓN, A. "La población informal. Poblamiento de la periferia de Santiago de Chile. 1920-1970”. EURE, v. XVI, n. 50, pp. 5-17, 1990. . Santiago de Chile (1541-1991): historia de una sociedad urbana. Santiago: Catalonia, 2007.

DECCACHE-MAIA, E. "Esporte e juventude no Borel". Estudos Históricos, v. 13, n. 23, pp. 192-206, 1999. 
DEVÉS VALDÉS, E. “La cultura obrera ilustrada chilena y algunas ideas en torno al sentido de nuestro quehacer historiográfico”. Mapocho: revista de humanidades y ciencias sociales, n. 30, pp. 127-33, 1991.

- "La circulación de las ideas y la inserción de los cientistas económico-sociales chilenos en las redes conosureñas durante los largos 1960”. Historia (Santiago), v. 37, pp. 337-66, $2004 a$.

- El pensamiento latinoamericano en el siglo XX: Entre la modernización y la identidad. Buenos Aires: Biblos - Centro de Investigaciones Barros Arana, 2004b, v. 3.

DIAS, E. História das lutas sociais no Brasil. São Paulo: Editora Edaglit, 1962. DÍAZ, F. "La reducción naturalista de lo popular en la Nueva Historia Social. Renovación historiográfica en tiempos de dictadura”. Revista Izquierdas, n. 21, pp. 152-77, 2014.

DINIZ, E. Voto e máquina politica: patronagem e clientelismo no Rio de Janeiro. Rio de Janeiro: Paz e Terra, 1982.

. "Favela: associativismo e participação social. In BOSCHI, R. (ed.). Movimentos coletivos no Brasil urbano. Rio de Janeiro: Zahar, 1983, pp. 27-74.

DOIMO, A. M. Movimento Social Urbano, Igreja e participação popular. Petrópolis: Vozes, 1984.

- A vez e a voz do popular: movimentos sociais e participação política no Brasilpós-70. Rio de Janeiro: Rellume-Dumará/ANPOCS, 1995.

DOMINGUES, J. M. Aproximaçoes à América Latina: desafios contemporâneos. Rio de Janeiro: Civilização Brasileira, 2007.

e MANEIRO, M. "Revisitando Germani: a interpretação da modernidade e a teoria da ação”. DADOS, v. 47, n. 4, pp. 643-68, 2004.

DOS SANTOS, T. “O Movimento Operário no Brasil”. Revista Brasiliense, n. 39, pp. 100-18, jan. 1962.

. Dependencia y cambio social. Buenos Aires: Amorrotu, 1973. 
DUBET, F. "Las Conductas marginales de los jóvenes pobladores". Proposiciones, v. 14, pp. 94-100, 1987. et al. Pobladores: luttes sociales et démocratie au Chile. Paris: L'Harmattan, 1989.

DUCCI, M. E. "Chile: el lado oscuro de una política de vivienda exitosa". EURE, v. XXIII, n. 69, pp. 99-115, jul. 1997.

DURHAM, E. R. "Movimentos sociais: a construção da cidadania”. Novos Estudos CEBRAP, n. 10, pp. 24-30, out. 1984.

ENGELS, F. A questão da habitação. Belo Horizonte: Aldeia Global Editora, 1979.

ESPINOZA, V. "El Movimiento de Pobladores: una evaluación crítica". Proposiciones, v. 5, pp. 41-52, 1982.

- "Movimiento popular urbano y procesos de institucionalización política”. Proposiciones, v. 11, pp. 57-65, 1984.

. "Los pobladores y la política". In CAMPERO, G. (ed.). Los movimientos sociales y la lucha democrática en Chile. Santiago: ILET, 1986, pp. 31-52.

. Para una Historia de los Pobres de la Ciudad. Santiago: Ediciones SUR, 1988.

. "Pobladores, participación social y ciudadanía: Entre los pasajes y las anchas alamedas". Proposiciones, v. 22, pp. 21-53, 1993.

- "Tiempos cortos y largos en el movimiento poblacional". Proposiciones, v. 24, pp. 246-50, 1994.

. "Historia social de la acción colectiva urbana: los pobladores de Santiago, 1957-1987”. EURE, v. 24, n. 72, pp. 71-84, set. 1998.

et al. "Poder local, pobladores y democracia". Proposiciones, v. 12, pp. 55-65, 1986.

EVERS, T. "Identidade: a face oculta dos novos movimentos sociais". Novos Estudos CEBRAP, v. 2, n. 4, pp. 11-23, abr. 1984. 
FANON, F. Los Condenados de la Tierra. México: Fondo de Cultura Económica, 2007.

FARÍAS, A. M. Urbanización, politica de vivienda y pobladores organizados en Las Barrancas: el caso de la población Neptuno, 1959-1968. Santiago: Pontificia Universidad Católica de Chile, 1992.

FAUSTO, B. Trabalho urbano e conflito social (1890-1920). São Paulo: Difel, 1977.

FAUSTO NETO, A. M. Q. "Violência e dominação: as favelas voltam à cena”. Revista Sociedade e Estado, v. X, n. 2, pp. 417-38, 1995.

FERNÁNDEZ, E. Estado y sociedad en Chile 1891-1931: el Estado excluyente, la lógica estatal oligárquica y la formación de la sociedad. Santiago: LOM, 2003.

FIELL, R. Da favela para as favelas. Rio de Janeiro: Visao da Favela Brasil, 2011.

FIORI, J. "Campamento Nueva La Habana: estudio de una experiencia de autoadministración de justicia”. EURE, v. 3, n. 7, pp. 83-101, 1973a. . A propósito del movimiento poblacional. Santiago: CIDU, $1973 \mathrm{~b}$.

FISCHER, B. A poverty of rights: citizenship and inequality in twentiethcentury Rio de Janeiro. Stanford: Stanford University Press, 2010.

FRANK, A. G. América Latina: subdesarrollo o revolución. Ciudad de México: Era, 1973a.

. Capitalismo y subdesarrollo en América Latina. Buenos Aires: Siglo Veintiuno Editores, 1973b.

. Lumpenburguesia: lumpendesarrollo. 3 ed. Ciudad de México: Era, 1978.

FRENCH, J. Afogados em leis: a CLT e cultura politica dos trabalhadores brasileiros. São Paulo: Editora Fundação Perseu Abramo, 2001.

GABAY, R. E. “Revisitando a Raúl Prebisch y al papel de la CEPAL en las Ciencias Sociales de América Latina”. Iconos, n. 031, pp. 103-13, maio 2008. 
GALLARDO, B. El redescubrimiento del carácter social del problema de hambre: las ollas comunes. Santiago: FLACSO, 1985. . "Espacio urbano y mundo poblacional". Programa FLACSO. n. 88, pp. 1-101, ago. 1986.

- "El redescubrimiento del carácter social del hambre: las ollas comunes". In POZO, H. (ed.). Espacio y poder: los pobladores. Santiago: FLACSO, 1987, pp. 174-201.

GARCÉS, M. Tomando su sitio. Santiago: LOM, 2002.

- "ECO, las ONGs y la lucha contra la dictadura militar en Chile. Entre lo académico y lo militante”. Revista Izquierdas, v. 3, n. 7, pp. 1-8, 2010.

- El despertar de la sociedad: los movimientos sociales en América Latina y Chile. Santiago: LOM, 2012.

GARRETÓN, M. A. "Las complejidades de la transición invisible. Movilizaciones populares y régimen militar en Chile". Proposiciones, v. 14, pp. 113-31, 1987.

GERMANI, G. Sociologia de la modernización: estudios teóricos, metodológicosy aplicados a América Latina. Buenos Aires: Paidós, 1971.

. El concepto de marginalidad: significado, raices históricas y cuestiones teóricas, con particular referencia a la marginalidad urbana. Buenos Aires: Nueva Visión, 1973a.

. Politica e sociedade numa época de transiçao: da sociedade tradicional à sociedade de massas. Sao Paulo: Mestre Jou, 1973b.

GIDDENS, A. Novas regras do método sociológico: uma crítica positiva das sociologias compreensivas. Rio de Janeiro: Zahar, 1978.

GIUSTI, J. Organización y participación popular en Chile: el mito del "hombre marginal". Santiago de Chile - Buenos Aires: FLACSO, 1973.

GOHN, M. da G. Reivindicações populares urbanas: um estudo sobre as Associações de Moradores em São Paulo. São Paulo: Cortez, 1982. - A força da periferia: a luta das mulheres por creches em São Paulo. Petrópolis: Vozes, 1985. 
GOLDWASSER, M. J. O Palácio do Samba: estudo antropológico da Escola de Samba Estação Primeira de Mangueira. Rio de Janeiro: Zahar, 1975.

GOMES, Â. de C. A invenção do trabalhismo. Rio de Janeiro: IUPERJ/ Vértice, 1988.

GOMES, M. As lutas do povo do Borel. Rio de Janeiro: Muro, 1980.

GÓMEZ LEYTON, J. C. "Las poblaciones callampas: una expresión de la lucha social de los pobres, Santiago, 1930-1960”. Estudios Sociales, n. 60, pp. 1-72, 1994.

GONÇALVES, C. W. P. “A territorialidade seringueira. Geografia e movimento social”. GEOgraphia, n. 2, pp. 6--88, 1999.

GÓNGORA, M. Ensayo histórico sobre la noción de Estado en Chile en los siglos XIX y XX. Santiago: La Ciudad, 1981.

GOODWIN, J. e JASPER, J. "Caught in a winding, snarling vine: the structural bias of political process theory". Sociological Forum, v. 14, n. 1, pp. 27-54, 1999.

GORELIK, A. "Laaldea en la ciudad.Ecos urbanos deun debate antropológico". Revista del Museo de Antropología, v. 1, n. 1, pp. 73-96, 2008.

GREZ, S. "Escribir la historia de los sectores populares ¿Con o sin la política incluida? A propósito de dos miradas a la historia social (Chile, siglo XIX)”. Política, v. 44, pp. 17-31, out. 2005.

GUTIÉRREZ, G. "Labor y contenido de la teología de la liberación”. In ROWLAND, C. (ed.). La teología de la liberación. Madrid: Cambridge University Press, 2000, pp. 41-63.

HARDY, C. Hambre + diginidad = ollas comunes. Santiago: PET, 1986.

. Organizarse para vivir: pobreza urbana y organización popular. Santiago: PET, 1987.

. La ciudad escindida. Santiago: PET, 1989.

HARVEY, D. "El derecho a la ciudad". New Left Review, n. 53, pp. 23-39, nov. 2008. 
HAUSER, P. (ed.). L'urbanisation en Amérique Latine. Liège: UNESCO, 1962.

JACOBI, P. "Movimentos populares urbanos e resposta do Estado: autonomia e controle vs. cooptação e clientelismo". In BOSCHI, R. (ed.). Movimentos Coletivos no Brasil Urbano. Rio de Janeiro: Zahar, 1983, pp. 145-79.

. "Movimentos Sociais Urbanos no Brasil: reflexões sobre a literatura nos anos 70 e 80". BIB, n. 23, pp. 18-34, 1987.

JAJAMOVICH, G. "Itinerarios de la Comisión de Desarrollo urbano y regional de CLACSO entre 1967 y 1973”. Revista de Estudios Sociales Contemporáneos, n. 12, pp. 162-77, 2015.

JOBET, J. C. Ensayo crítico del desarrollo económico-social de Chile. Santiago de Chile: Editorial Universitaria, 1951.

. Luis Emilio Recabarren: los origenes del movimiento obrero y del socialismo chilenos. Santiago de Chile: Prensa Latinoamericana, 1955.

JORDÁ SUREDA, M. Martirologio de la Iglesia Chilena: Juan Alsina y sacerdotes víctimas del terrorismo de Estado. Santiago: LOM, 2001.

JUNQUEIRA, E. B. e RODRIGUES, J. A. de S. "Pasárgada revisitada”. Sociologia - Problemas e Práticas, n. 12, pp. 9-17, 1992.

KÄRNER, H. "Movimentos sociais: revolução no cotidiano". In SCHERER-WARREN, I. e KRISCHKE, P. (eds.). Uma revolução no cotidiano? Os novos movimentos sociais na América do Sul. São Paulo: Brasiliense, 1987, pp. 19-34.

KOWARICK, L. Capitalismo e Marginalidade na América Latina. Rio de Janeiro: Paz e Terra, 1975. . A espoliação urbana. Rio de Janeiro: Paz e Terra, 1979. . "Movimentos urbanos no Brasil contemporâneo: uma análise da literatura”. Revista Brasileira de Ciências Sociais, v. 1, n. 3, pp. 38-50, fev. 1987. 
KRIÉS, R. "Confiar en sí mismos. Las organizaciones de Base en Chile”. Nueva Sociedad, n. 64, pp. 39-46, jan. 1983.

LABARCA, E. Chile invadido: reportaje de la intromisión extranjera. Santiago: Editora Austral, 1969.

LACERDA, C. Depoimento. Rio de Janeiro: Nova Fronteira, 1987.

LANDSBERGER, H. e MCDANIEL, T. "Hypermobilization in Chile, 1970-1973”. World Politics, v. 28, n. 4, pp. 502-41, 1976.

LANZARA, A. P. A construçao histórica do Estado Social no Brasil e no Chile: do mutualismo ao seguro (tese). UERJ, 2012.

LARRAÍN, J. Theories of development: capitalism, colonialism and dependency. Cambridge: Polity Press, 1989.

LEEDS, A. "The significant variables determining the character of squatter settlements". América Latina, v. 12, n. 3, pp. 44-86, jul. 1969.

e LEEDS, E. A sociologia do Brasil urbano. Rio de Janeiro: Zahar Editores, 1978.

LEEDS, E. "Cocaína e poderes paralelos na periferia urbana brasileira: ameaças a democratização em nível local”. In ZALUAR, A. e ALVITO, M. (eds.). Um século de favela. Rio de Janeiro: FGV, 1998, pp. 233-76.

LEFEBVRE, H. $O$ direito à cidade. 5 ed. São Paulo: Centauro, 2010.

LEITE, M. P. "Violência, risco e sociabilidade nas margens da cidade: percepções e formas de ação de moradores de favelas cariocas". In SILVA, L. A. M. da (ed.). Vida sob cerco: violência e rotina nas favelas do Rio de Janeiro. Rio de Janeiro: Nova Fronteira, 2008, pp. 115-41.

LESBAUPIN, I. “A Igreja e movimentos populares urbanos”. Religião e Sociedade, n. 5, 1980.

LEWIS, O. Antropología de la pobreza: cinco familias. México: Fondo de Cultura Económica, 1961.

. Los Hijos de Sánchez. México: Grijalbo, 1982.

LEZAMA, J. L. Teoria social, espacio y ciudad. México: Colegio de México, 2002. 
LIMA, N. V. T. O movimento dos favelados do Rio de Janeiro (dissertação). IUPERJ, 1989.

LOJKINE, J. El marxismo, el Estado y la cuestión urbana. México: Siglo Veintiuno, 1979.

LOMNITZ, L. Cómo sobreviven los marginados. 6 ed. México: Siglo Veintiuno Editores, 1983.

LOPES, J. S. L. "Igreja e movimentos populares urbanos: Comentários ao artigo de Ivo Lesbaupin”. Religião e Sociedade, n. 5, pp. 199-204, 1980.

et al. "Esboço de uma história social da primeira geração de sociólogos do trabalho e dos trabalhadores no Brasil". Educação \& Sociedade, v. 33, n. 118, pp. 115-29, mar. 2012.

LOYOLA, M.Lospobladores de Santiago, 1952-1964: su fase de incorporación a la vida nacional. Santiago: Ediciones Universidad Católica Raúl Silva Henríquez, 2006.

- "Gabriel Salazar en el nombre del poder popular constituyente (Chile, siglo XXI)". Cuadernos de historia (Santiago), n. 36, pp. 183-5, 2012.

MAGALHÃES, A. A. de. Transformações no "problema favela" e a reatualização da "remoção" no Rio de Janeiro (tese). UERJ, 2013.

MAINWARING, S. e VIOLA, E. "New social movements, political culture, and democracy: Brazil and Argentina in the 1980s". Telos, n. 61, pp. 17-52, 1984.

MANGIN, W. "Latin American squatter settlements: a problem and a solution”. Latin American Research Review, v. 2, n. 3, pp. 65-97, 1967.

MANNHEIM, K. Ensayos sobre sociología y psicología social. México: FCE, 1963.

MARDONES, R. “¡No en mi patio trasero!: el caso de la comunidad ecológica de Peñalolén”. Íconos, n. 34, pp. 139-49, 2009.

MARICATO, E. et al. Cidades rebeldes: Passe Livre e as manifestações que tomaram as ruas do Brasil. São Paulo: Boitempo-Carta Maior, 2013. 
MARSHALL, M. T. "Criterios comunes del trabajo social en poblaciones". Proposiciones, v. 5, pp. 53-63, 1982.

MARX, C. El Capital: crítica de la economía politica. México: FCE, 1946, v. 1. . Grundrisse. São Paulo: Boitempo, 2011.

MASSARDO, J. La formación del imaginario político de Luis Emilio Recabarren: contribución al estudio critico de la cultura politica de las clases subalternas de la sociedad chilena. 1 ed. Santiago: LOM, 2008.

MCADAM, D. et al. "Para mapear o confronto político". Lua Nova, n. 76, pp. 11-48, 2009.

MEDINA, C. A. de. A favela e o demagogo. Sao Paulo: Martins, 1964.

. "A favela como uma estrutura atomística: elementos descritivos e constitutivos". América Latina, v. 12, n. 3, pp. 112-36, jul. 1969.

MELLO, M. A. da S. et al. (eds.). Favelas Cariocas ontem e hoje. Rio de Janeiro: Garamond, 2012.

MERTON, R. Sociologia: Teoria e Estrutura. Sao Paulo: Mestre Jou, 1970.

MILláN, R. Un cubano en Chile. Alejandro Portes y su teoría de la racionalidad poblacional. XXIX Congreso Latinoamericano de Sociología, 2013

MILLS, C. W. La imaginación sociológica. Santiago: FCE, 1995.

MOISÉS, Á. “O Estado, as contradições urbanas e os movimentos sociais”. In___ (ed.). Cidade, povo e poder. Rio de Janeiro: Paz e Terra, 1982, pp. 14-29.

. "Protesto urbano e política. O quebra-quebra de 1947". In RODRIGUES DA SILVA, C. et al. (eds.). Movimentos Sociais Urbanos, minorias étnicas e outros estudos. Brasília: ANPOCS, 1983, pp. 96-112. e MARTINEZ-ALIER, V. “A revolta dos suburbanos ou 'patrão, o trem atrasou'”. In et al. (eds.). Contradições urbanas e movimentos sociais. Rio de Janeiro: Paz e Terra, 1978.

MORAES FILHO, E. O problema do sindicato único no Brasil: seus fundamentos sociológicos. São Paulo: Alfa-Ômega, 1978. 
MORALES, E. "Integración social, marginalidad y mercados de trabajo. Notas para discusión”. Programa FLACSO, n. 32, pp. 1-38, set. 1982. . "Algunos indicadores de niveles de vida en campamentos de la comuna del Gran Santiago". Programa FLACSO, n. 178, pp. 1-65, maio 1983.

e ROJAS, S. "Relocalización socio-espacial de la pobreza. Política estatal y presión popular, 1979-1985”. In POZO, H. (ed.). Espacio y poder: los pobladores. Santiago: FLACSO, 1987, pp. 75-121.

MORALES, J. J. “José Medina Echavarría y la sociología del desarrollo”. Íconos, n. 36, pp. 133-46, 2010.

MORSE, R. La investigación urbana latinoamericana: tendencias y planteos. Buenos Aires: SIAP, 1971.

MOULIAN, L.e DE WOLF, L. Herminda de La Victoria: aspectos históricos. Santiago: Vicaría Zona Oeste, 1990.

MPL. Siete y cuatro: el retorno de los pobladores. Santiago: Quimantú, 2011. NUN, J. "Superpoblación relativa, ejército industrial de reserva y masa marginal". In: . (ed.). Marginalidad y exclusión social. Buenos Aires: FCE, 1969, pp. 35-140.

. "Marginalidad y otras cuestiones". In . (ed.). Marginalidad y exclusión social. Buenos Aires: FCE, 1971, pp. 185-247.

. "Nueva visita a la teoría de la marginalidad". In: (Ed.). Marginalidady Exclusión Social. Buenos Aires: FCE, 1999, pp. 249-300. . Marginalidad y exclusión social. Buenos Aires: Fondo de Cultura Económica, 2001.

et al. La marginalidad en América Latina - informe preliminar. Buenos Aires: Instituto Torcuato Di Tella - Centro de Investigaciones Sociales, 1968.

NUNES, E. "Movimientos y prácticas urbanas en el Brasil: problemas sobre la democratización del poder local dentro de una transición inconclusa”. Revista Mexicana de Sociología, v. XLVIII, n. 4, pp. 73-86, out. 1986. 
e JACOBI, P. “Movimentos populares urbanos, participação e democracia”. In RODRIGUES DA SILVA, C. et al. (eds.). Movimentos Sociais Urbanos, minorias étnicas o outros estudos. Brasília: ANPOCS, 1983, pp. 25-62.

OLIVEIRA, F. de. "A economia brasileira: crítica a razão dualista”. Estudos CEBRAP, v. 2, pp. 4-82, 1972.

OLIVEIRA, J. S. de e MARCIER, M. H. “A palavra é favela”. In ZALUAR, A. e ALVITO, M. (eds.). Um século de favelas. Rio de Janeiro: FGV, 1998, pp. 61-114.

OLIVEN, R. G. “Marginalidad urbana en América Latina”. EURE, v. 7, n. 19, pp. 49-62, out. 1980.

OLSON, M. “La lógica de la acción colectiva”. In BATLLE RUBIO, A. (org.) Diez textos básicos de ciencia política. Madrid: Ariel, 2001, pp. 203-20.

ORTIZ LETELIER, F. El Movimiento Obrero en Chile (1981-1919). Santiago: LOM, 2005.

OXHORN, P. "Where did all the protesters go?: popular mobilization and the transition to democracy in Chile". Latin American Perspectives, v. 21, n. 3, pp. 49-68, 1 jul. 1994.

- "La paradoja del gobierno autoritario: organización de los sectores populares en los ochenta y promesa de inclusión”. Politica, n. 43, pp. 57-83, 2004.

PAIVA, M. Pasado: victoria del presente. Santiago: s. n., 1989.

PAIXÃO, A. L. "A violência urbana e a Sociologia: sobre crenças e fatos e mitos e teorias e políticas e linguagens”. Religião e Sociedade, v. 15, n. 1, pp. 68-81, 1990.

PANDOLFI, D. C.e GRYNSZPAN, M. (eds.). A favela fala: depoimentos ao CPDOC. Rio de Janeiro: FGV, 2003.

PAOLI, M. C. Desenvolvimento e marginalidade. São Paulo: Pionera, 1974. . "Conflitos sociais e ordem institucional: cidadania e espaço público no Brasil do século XX”. Revista da OAB, n. 53, pp. 80-92, 1989. 
et al. "Pensando a classe operária: os trabalhadores sujeitos ao imaginário acadêmico". Revista Brasileira de História, v. 3, n. 6, pp. 12949, 1984.

PARISSE, L. "Las favelas en la expansión urbana de Río de Janeiro: estudio geográfico". América Latina, v. 12, n. 3, pp. 7-43, jul. 1969.

PARK, R. E. "Human migration and the marginal man". American Journal of Sociology, v. XXXIII, n. 6, maio 1928.

PASTRANA, E. e THRELFALL, M. Pan, techo y poder: el movimiento de pobladores en Chile (1970-1973). Buenos Aires: Ediciones Siap, 1974.

PEARSE, A. «Quelques caractéristiques de l'urbanisation dans la Ville de Rio de Janeiro». In HAUSER, P. (ed.). L'urbanisation en Amérique Latine. Liège: UNESCO, 1962, pp. 192-205.

PÉREZ, M. A. Memorias del campamento cardenal Raúl Silva Henríquez y de lapoblación Almendro II. Santiago: Pontificia Universidad Católica, 1995.

PERLMAN, J. O mito da marginalidade: favelas e politica no Rio de Janeiro. Rio de Janeiro: Paz e Terra, 1977.

PFEIFFER, P. (ed.). Organizações de base e desenvolvimento político no Rio de Janeiro. Berlim: LAI, 1983.

PIERRE-CHARLES, P. Frantz Fanon l'héritage. Fort-de-France: K Éditions, 2011.

PIMENTEL, C. Vidas marginales. Santiago: Editorial Universitaria, 1972.

PIÑA, C. «'Lo popular': notas sobre la identidad cultural de las clases subalternas». In POZO, H. (ed.). Espacio y poder: los pobladores. Santiago: FLACSO, 1987, pp. 259-92.

PINHEIRO, P. S. Politica e trabalho no Brasil. Rio de Janeiro: Paz e Terra, 1975.

PINTO, J. "Movimiento social popular: ¿hacia una barbarie con recuerdos?" Proposiciones, n. 24, pp. 214-9, 1998. 
et al. "Historia contemporánea de Chile II: actores, identidad y movimiento". InSALAZAR, G.e (eds.).Historia contemporánea de Chile. Santiago: LOM, 1999.

PLEYERS, G. "La sociología de Alain Touraine". Estudios Sociológicos, v. XXIV (3), n. 72, pp. 733-56, 2006.

PONCE, J. I. e PÉREZ, A. "La revitalización de la historiografía política chilena”. Polis (Santiago), v. 12, n. 36, pp. 453-76, dez. 2013.

PONTES, H. Destinos mistos: os críticos do Grupo Clima em São Paulo. São Paulo: Companhia Das Letras, 1998.

PORTES, A. Cuatro poblaciones: informe preliminar sobre situación y aspiraciones de grupos marginados en el Gran Santiago. Santiago: Universidad de Wisconsin, 1969.

- "Leftist radicalism in Chile: a test of three hyphoteses". Comparative Politics, v. 2, n. 2, pp. 251-74, 1970.

."The urban slum in Chile: types and correlates". Land Economics, v. 47, n. 3, pp. 235-48, 1971.

. "Rationality in the slum: an essay on interpretative sociology". Comparative studies in society and history, v. 14, n. 3, pp. 268-86, 1972.

. "Housing policy, urban poverty, and the state: the favelas of Rio de Janeiro, 1972-1976”. Latin American Research Review, v. 14, n. 2, pp. 3-24, 1979.

POZO, H. “Inteligibilidad y sentido del trabajo con pobladores”. Programa FLACSO. n. 193, pp. 1-40, out. 1983. (ed.). Espacio y poder: los pobladores. Santiago: FLACSO, 1987.

PREBISCH, R. El desarrollo económico de la América Latina y susprincipales problemas. Naciones Unidas Consejo Económico y Social, 1947.

. "Exposición del Doctor Raul Prebisch, Director Principal a cargo de la Secretaría Ejecutiva de la CEPAL, en la Primera Reunión Plenaria del Décimo Periodo de Sesiones, realizada en Mar del Plata el 6 de mayo de 1963”. Desarrollo Económico, v. 2, n. 4, pp. 151-66, jan. 1963. 
QUEVEDO, S. e SADER, E. “Algunas consideraciones en relación a las nuevas formas de poder popular en poblaciones". EURE, v. 3, n. 7, pp. 71-81, abr. 1973.

QUIJANO, A. Elproceso de urbanización en Latinoamérica (esquema de un marco de revisión de la problemática). Santiago: CEPAL, 1966.

- Dependencia, cambio social y urbanización en Latinoamérica. Santiago: División de Asuntos Sociales CEPAL, 1967.

- Urbanización y tendencias de cambio en la sociedad rural latinoamericana. Santiago: CIDU, 1968.

- Redefinición de la dependencia y proceso de marginalización en América Latina. Santiago: OIT-ILPES Mimeo, 1970.

- "Introducción". In PIMENTEL, C. (ed.). Vidas marginales. Santiago: Editorial Universitaria, 1972a , pp. 9-28.

. "La constitución del 'mundo' de la marginalidad urbana”. EURE, v. 2, n. 5, pp. 89-106, jul. 1972b.

QUINTANILLA, R. Yo soy pobladora. Santiago: PIRET, 1990.

RAMÍREZ NECOCHEA, H. "Historia del Movimiento Obrero en Chile: antecedentes siglo XIX”. In (ed.). Obras escogidas. Santiago: LOM, 2007a, v. I.

. "Origen y formación del Partido Comunista de Chile". In: (ed.). Obras Escogidas. Santiago: LOM, 2007b, v. II.

RAMOS, C. El ensamblaje de ciencia socialy sociedad: conocimiento cientifico, gobierno de las conductas y producción de lo social. Santiago: Universidad Alberto Hurtado, 2012.

RAZETO, L. et al. Las Organizaciones Económicas Populares, 1973-1990. Santiago: PET, 1990.

RECABARREN, L. E. Ricos y pobres. Santiago: LOM Ediciones, 2010.

RIBEIRO, A. C. T. Movimentos Sociais Urbanos - registros brasileiros: estudos e debates. Rio de Janeiro: PUR/UFRJ, out. 1982a. 
. O fato metropolitano - espaço e sociedade: publicações PUR. Rio de Janeiro: PUR/UFRJ, jul. 1982b.

e LIMONAD, E. Infraestrutura e super-estrutura: dois caminhos para uma mesma questão: estudos e debates. Rio de Janeiro: PUR/UFRJ, out 1982.

RIBEIRO, L. C. de Q. e SANTOS JUNIOR, O. A. dos (eds.). As metrópoles e a questão social brasileira. Rio de Janeiro: Editora Revan, 2007.

RIOS, J. A. “Aspectos humanos das favelas cariocas - 50 anos: uma avaliação”. In MELLO, M. A. da S. et al. (eds.). As favelas cariocas ontem e hoje. Rio de Janeiro: Garamond, 2012, pp. 35-50.

RODRIGUES, J. A. Sindicato e desenvolvimento no Brasil. São Paulo: Difusão Europeia do Livro, 1968.

RODRÍGUEZ, A. Por una ciudad democrática. Santiago: SUR, 1983.

. Constructores de ciudad: nueve historias del primer concurso de "Historia de las poblaciones". Santiago: SUR Ediciones, 1989. et al. "De invasores a invadidos". EURE, v. 2, n. 4, pp. 101-42, 1972. e SUNGRAYES, A. (eds.). Los con techo: un desafio para la politica de vivienda social. Santiago: Ediciones SUR, 2006.

ROITMAN ROSENMANN, M. "Conflicto y crisis en el pensamiento social latinoamericano". OSAL Observatorio Social de América Latina, v. 2, pp. 165-70, set. 2000.

ROJAS, J. "Los trabajadores en la historiografía chilena: balance y proyecciones". Revista de Economía \& Trabajo, n. 10, pp. 47-117, 2000.

. "Percepciones en torno a la radicación de pobres urbanos: el caso de la 'Toma' de Peñalolén”. Boletín de Geografía, n. 24-25, pp. 103-22, 2006.

ROSENBLÜTH, G. "Problemas socio-económicos de la marginalidad y la integración urbana”. Revista Paraguaya de Sociología, v. 5, n. 11, pp. 11 74, abr. 1968. 
ROVIRA, C. "Globalización en América Latina: sobre los aportes y perjuicios sociales de la dependencia”. Persona y Sociedad, v. XIX, n. 3, pp. 63-84, 2005.

ROWLAND, C. La teología de la liberación. Madrid: Cambridge University Press, 2000.

SABATINI, F. "La dimensión ambiental de la pobreza urbana en las teorías latinoamericanas de la marginalidad”. EURE, v. 8, n. 23, pp. 53-67, 1981. . "Participación de pobladores en organizaciones de barrio". EURE, v. XV, n. 46, pp. 47-66, 1989.

. "La organización de los pobladores: discusión de interpretaciones". Revista de Trabajo Social, n. 57, pp. 120-33, 1990.

e WORMALD, G. "La guerra de la basura de Santiago: desde el derecho a la vivienda al derecho a la ciudad”. EURE, v. XXX, n. 91, pp. 67-86, dez. 2004.

SADER, E. Quando novos personagens entraram em cena: experiências elutas dos trabalhadores da grande São Paulo 1970-1980. Rio de Janeiro: Paz e Terra, 2010.

SALAZAR, G. Labradores, peones y proletarios: formación y crisis de la sociedad chilena del siglo XIX. Santiago de Chile: LOM, 2000.

. La violencia política popular en las "Grandes Alamedas": la violencia en Chile 1947-1987 (una perspectiva histórico popular). Santiago: LOM, 2006.

- Movimientos sociales en Chile: trayectoria histórica y proyección politica. Santiago: Uqbar, 2013.

et al. "Estado, legimitidad, ciudadanía. Volumen I». In JULIO, P. (ed.). Historia contemporánea de Chile. Santiago: LOM, 1999.

SALINAS, M. «La recherche d'un lieu sacré: la trajectoire sociale et religieuse des pobladores au Chili (1962-1992)». Social Compass, v. 43, n. 3, pp. 353-66, 1996. 
SALMAN, T. "La base social persistente. nuevos movimientos sociales en América Latina: cambio, resistencia y lentitud”. Proposiciones, v. 28, pp. 88-115, 1998.

SÁNCHEZ, D. "Instituciones y acción poblacional: seguimiento de su acción en el período 1973-1981”. In POZO, H. (ed.). Espacio y poder: los pobladores. Santiago: FLACSO, 1987, pp. 123-70.

SANTANA, M. A. “O ‘novo' e o 'velho' sindicalismo: análise de um debate”. Revista de Sociologia e Politica, v. 10/11, pp. 19-35, 1998.

SANTAPAU, D. Elevangelio hecho "acción”. Sacerdotes franceses y pobladores de "La Victoria" (1983-1986). Santiago: Instituto de Historia PUC Chile, 2005.

SANTONI, A. "El Partido Comunista Italiano y el otro "compromesso storico": los significados políticos de la solidaridad con Chile (19731977)”. Historia, v. II, n. 43, pp. 523-46, jul. 2010.

SANTOS, B. "Sociologia na primeira pessoa: fazendo pesquisa nas favelas do Rio de Janeiro". Revista da OAB, n. 49, pp. 39-79, 1989.

SANTOS, C. N. F. dos. Movimentos urbanos no Rio de Janeiro. Rio de Janeiro: Zahar, 1981.

. "Em trinta anos passou muita água sob as pontes urbanas". Espaço \& Debates, v. 4, n. 11, pp. 28-40, 1984.

SANTOS, M. Por uma geografia nova. 6 ed. São Paulo: EDUSP, 2008.

SANTOS, M. S. dos. "Mangueira e Império: a carnavalização do poder pelas escolas de samba”. In ZALUAR, A. e ALVITO, M. (eds.). Um século de favela. Rio de Janeiro: FGV, 1998a, pp. 115-44.

SANTOS, W. G. dos. "A Práxis liberal e a cidadania regulada”. In (ed.). Décadas de espanto e uma apologia democrática. Rio de Janeiro: Rocco, 1998b, pp. 63-114.

SCHERER-WARREN, I. "O caráter dos novos movimentos sociais". In e KRISCHKE, P. (eds.). Uma revolução no cotidiano? Os novos 
movimentos sociais na América do Sul. São Paulo: Brasiliense, 1987, pp. 35-53.

SCHERMAN, J. Techo y abrigo. las organizaciones populares de vivienda: Chile, 1974-1988. Santiago: PET, 1990.

SCHKOLNIK, M. e TEITELBOIM, B. Pobreza y desempleo en poblaciones: la otra cara del modelo neoliberal. Santiago: PET, 1988.

SCHMIDT, B. V. "A politização do espaço urbano no Brasil”. Espaço \& Debates, v. 2, n. 5, pp. 5-30, 1982.

SCHNEIDER, C. "La movilización de las bases, poblaciones marginales y resistencia en Chile autoritario". Proposiciones, v. 19, pp. 223-43, 1990.

. Shantitown protest in Pinochet's Chile. Philadelphia: Temple, 1995.

SCHÜHLY, G. F. Marginalidade: um estudo do "migrante estabelecido" no Brasil. Rio de Janeiro: Agir, 1981.

SEGALL, M. Desarrollo del capitalismo en Chile: cinco ensayos dialécticos. Santiago de Chile: Del Pacífico, 1953.

SEPÚlVEDA, D. "De tomas de terrenos a campamentos: movimiento social y político de los pobladores sin casa, durante las décadas del $60 \mathrm{y}$ 70, en la periferia urbana de Santiago de Chile”. Boletín INVI, v. 13, n. 35, pp. 103-15, 1998.

SILBERSTEIN, P. "Favela living: personal solution to larger problems. América Latina, v. 12, n. 3, pp. 183-200, jul. 1969.

SILVA, A. A. da. "Dimensões da Interlocução Pública: cidade, movimentos sociais e direitos”. In: DINIZ, E. et al. (eds.). O Brasil no rastro da crise: partidos, sindicatos, movimentos sociais, Estado e cidadania no curso dos anos 90. São Paulo: ANPOCS-Editora HUCITEC-IPEA, 1994, pp. 204-24.

SILVA, L. A. M. da “A política na favela”. Cadernos Brasileiros, n. 41, pp. 35-47, maio 1967.

. "O significado do botequim". América Latina, v. 12, n. 3, pp. 16082, jul. 1969. 
- Mercados de Trabalho Manual e Marginalidade (dissertação). UFRJ, 1971.

- Desdobramentos do campo temático dos movimentos sociais. XIV Reunião Anual de ANPOCS, 1990

- "Criminaliade violenta: por uma nova perspectiva de análise”. Revista de Sociologia e Politica, n. 13, pp. 115-24, 1999.

. “A continuidade do "problema da favela". In OLIVERIA, L. L. (ed.). Cidade: história e desafios. Rio de Janeiro: FGV/CNPq, 2002, pp. 220-37.

.Vida sob serco: violência e rotinas nas favelas do Rio de Janeiro. Rio de Janeiro: Nova Fronteira, 2008.

. "A partir do relatório SAGMACS: as favelas, ontem e hoje”. In MELLO, M. A. da S. et al. (eds.). As favelas cariocas ontem e hoje. Rio de Janeiro: Garamond, 2012a, pp. 51-63.

. "Violencia en Rio de Janeiro: ¿hay cambios?" In SOSMAN, A. e CARREÑO, J. (eds.). Violencia(s) coordenadas y perspectivas: aportes para una praxis transformadora. Valparaíso: Mallku, 2012b, pp. 216-53.

e RIBEIRO, A. C. T. "Paradigma e movimento social: por onde andam nossas ideias?” In ANPOCS (ed.). Ciências Sociais hoje. São Paulo: Cortez-ANPOCS, 1985, pp. 318-36.

e ZICCARDI, A. "Notas para uma discussão sobre 'Movimentos Sociais Urbanos”. In RODRIGUES DA SILVA, C. et al. (eds.). Movimentos Sociais Urbanos, minorias etnicas e outros estudos. Brasília: ANPOCS, 1983, pp. 9-24.

SILVA, M. L. P. da. Favelas cariocas 1930-1964. Rio de Janeiro: Contraponto, 2005.

SILVA TELLO, R. "Pobladores somos y qué fue" 1959-1969. Santiago: Taller Gráfico Rodríguez, 1970.

SIMÃO, A. Sindicato e Estado. São Paulo: Dominus, 1966.

SINGER, P. Economia politica da urbanização. São Paulo: Brasiliense, 1978. 
. "Movimentos de bairro". In: e BRANT, V. C. (eds.). São Paulo: o povo em movimento. Rio de Janeiro: Vozes-CEBRAP, 1982a, pp. 83-107.

. "Movimentos sociais em São Paulo: traços comuns e perspectivas". In e BRANT, V. C. (eds.). São Paulo: o povo em movimento. Rio de Janeiro: Vozes-CEBRAP, 1982b, pp. 207-30.

SOUTO, A. L. S. "Movimentos populares urbanos e suas formas de organização ligadas à Igreja”. In RODRIGUES DA SILVA, C. et al. (eds.). Movimentos Sociais Urbanos, minorias étnicas e outros estudos. Brasília: ANPOCS, 1983, pp. 63-95.

STAVENHAGEN, R. "Descolonizing applied social sciences". Human Organization, v. 30, n. 4, pp. 333-57, 1971.

STONEQUIST, E. “The problem of the marginal man”. American Journal of Sociology, v. XLI, n. 1, pp. 1-12, jul. 1935.

SUNKEL, O. "Desarrollo, subdesarrollo, dependencia, marginación y desigualdades espaciales; hacia un enfoque totalizante". EURE, v. 1, n. 1, pp. 13-49, nov. 1970.

TARROW, S. O poder em movimento: movimentos sociais e confronto político. Petrópolis: Editora Vozes, 2009.

TELLES, V. da S. "Movimentos sociais: reflexões sobre a experiência dos anos 70". In SCHERER-WARREN, I. e KRISCHKE, P. (eds.). Uma revolução no cotidiano? Os novos movimentos sociais na América do Sul. São Paulo: Brasiliense, 1987, pp. 54-81.

THIELEMANN, L. "El Movimiento Popular y la historiografía en Chile: elementos para un balance a 40 años del Golpe de Estado". Revista de Historia y Geografia UCSH, n. 29, pp. 105-30, 1 jul. 2013.

TILLY, C. "Los movimientos sociales como agrupaciones históricamente específicas de actuaciones políticas”. Sociológica, v. 10, n. 28, maio 1995. . "Spaces of Contention". Mobilization: An International Quarterly, v. 5, n. 2, pp. 135-59, 2000. 
TIRONI, E. “La revuelta de los pobladores: integración social y democracia”. Nueva Sociedad, n. 83, pp. 24-32, maio 1986.

. "Marginalidad, movimientos sociales y democracia”. Proposiciones, v. 14, pp. 8-20, ago. 1987a.

. "Pobladores e integración social". Proposiciones, v. 14, pp. 64-84, ago. $1987 \mathrm{~b}$.

TIRONI, E. et al. "Intervención sociológica con pobladores". Proposiciones, v. 12, pp. 43-53, 1986.

TOURAINE, A. «Industrialization et conscience ouvrière à São Paulo». Sociologie du Travail, v. 3, n. 4, pp. 75-95, out. 1961.

. Vie et mort du Chili populaire. Paris: Seuil, 1973.

. Les sociétés dépendantes. Paris-Gembloux: Éditions J. Duculot, 1976.

. "Introducción al método de la intervención sociológica”. Estudios Sociológicos, v. 4, n. 11, pp. 197-213, 1986.

. "La centralidad de los marginales". Proposiciones, v. 14, pp. 214-24, 1987.

. Palavra e sangue: política e sociedade na América Latina. Campinas: Editora da UNICAMP/Trajetória Cultural, 1989.

. Critica de la modernidad. México: Fondo de Cultura Económica, 1994.

TURNER, J. "Uncontrolled urban settlement: problems and policies". Internacional Social Development Review, n. 1, pp. 107-28, 1968.

VALDÉS, T.Elmovimiento poblacional: la recomposición de las solidaridades sociales. Santiago: FLACSO, 1986.

e WEINSTEIN, M. "Organizaciones de pobladoras y construcción democrática en Chile. Notas para un debate”. Programa FLACSO, n. 434, pp. 1-43, out. 1989.

et al. "Las coordinadoras de organizaciones populares. Cinco Experiencias". Programa FLACSO, n. 382, pp. 1-123, set. 1988. 
VALENZUELA, E. "La rebelión de los jóvenes”. Proposiciones, v. 11, pp. 44-57, 1984.

. "Los jóvenes y la crisis de la modernización”. In CAMPERO, G. (ed.). Los movimientos sociales y la lucha democrática en Chile. Santiago: ILET, 1986, pp. 21-9.

VALLADARES, L. do P. “Associações voluntárias na favela”. Ciência e Cultura, v. 29, n. 12, pp. 1390-403, dez. 1977.

VALLADARES, L. do P. "Favelas, política e conjunto residencial". In BLAY, E. A. (ed.). A luta pelo espaço: textos de sociologia urbana. Petrópolis: Vozes, 1978a , pp. 109-24.

. Passa-se uma casa. Rio de Janeiro: Zahar, 1978b.

. “A propósito da urbanização de favelas". Espaço \& Debates, v. 1, n. 2, pp. 5-18, 1981.

- "Quebra-quebras na construção civil: o caso dos operários do metrô do Rio de Janeiro". In RODRIGUES DA SILVA, C. et al. (eds.). Movimentos Sociais Urbanos, minorias étnicas e outros estudos. Brasília: ANPOCS, 1983, pp. 113-43.

. A invençao da favela: do mito de origem a favela.com. Rio de Janeiro: FGV Editora, 2005.

- "A descoberta do trabalho de campo em 'Aspectos humanos da favela carioca"”. In MELLO, M. A. da S. et al. (eds.). Favelas cariocas: ontem e hoje. Rio de Janeiro: Garamond, 2012, pp. 65-99.

e COELHO, M. P. "La investigación urbana en América Latina: tendencias actuales y recomendaciones". Cadernos IPPUR, v. X, n. 1, pp. 103-41, 1996.

e MEDEIROS, L. Pensando as favelas do Rio de Janeiro. 1906-2000. Uma bibliografia analítica. Rio de Janeiro: Relume Dumará, 2003.

VAN HEMELRYCK, L. et al. "Organizaciones populares y desarrollo local: elementos para un debate”. Proposiciones, v. 13, pp. 165-9, 1987. 
VANDERSCHUEREN, F. "Significado político de las juntas de vecinos en poblaciones de Santiago”. EURE, v. 1, n. 2, pp. 67-90, jun. 1971a. . "Pobladores y conciencia social". EURE, v. 1, n. 3, pp. 95-123, nov. $1971 \mathrm{~b}$.

VÁRELA PETITO, G. "Gino Germani en su circunstancia”. Perfiles latinoamericanos, v. 16, n. 32, pp. 235-43, jul. 2008.

VEIT STRASSNER, M. A. "La Iglesia chilena desde 1973 a 1993: de buenossamaritanos, antiguos contrahentes y nuevos aliados. Un análisis politológico". Teología y Vida, v. 47, n. 1, pp. 76-94, 2006.

VEKEMANS, R. e SILVA, I. "El concepto de marginalidad". In DESAL (ed.). Marginalidad en América Latina: un ensayo de diagnóstico. Santiago: Herder, 1969, pp. 15-63. e . Marginalidad, promoción popular y neo-marxismo. Bogotá: CEDIAL, 1976.

VENTURA, Z. Cidade partida. São Paulo: Companhia das Letras, 1995.

VÉRAS, M. P. B. "Sociedade urbana: desigualdade e exclusao sociais". Caderno CRH, n. 38, pp. 79-114, jan. 2003.

VIANNA, L. W. Liberalismo e sindicato no Brasil. Rio de Janeiro: Paz e Terra, 1976.

VIANNA, O. Direito do trabalho e democracia social: o problema da incorporação do trabalhador no Estado. Rio de Janeiro: José Olympio, 1951.

VIGEVANI, T. "Movimentos sociais na transição brasileira: a dificuldade de elaboração do projeto”. Lua Nova, n. 17, pp. 93-109, 1989.

WEFFORT, F. Sindicatos e política. São Paulo: USP, 1970.

. O populismo na política brasileira. Rio de Janeiro: Paz e Terra, 1978.

WEINSTEIN, J. Los jóvenes pobladores en las protestas nacionales (198384): una visión sociopolitica. Santiago: CIDE, 1988a. 
- Entre la ausencia y el acoso: apuntes bibliográficos sobre jóvenes pobladores, vida cotidiana y Estado en Chile hoy. Santiago: CIDE, 1988, v. 22.

- "Víctimas y beneficiarios de la modernización: inventario (incompleto) de cambios en la juventud pobladora (1965-90)". Proposiciones, v. 20, pp. 250-74, 1991.

ZALUAR, A. A máquina e a revolta: as organizaçõespopulares e os significados da pobreza. São Paulo: Brasiliense, 1985.

. "Teleguiados e chefes: juventude e crime". Religião e Sociedade, v. 15, n. 1, pp. 54-67, 1990.

. “Crime, medo e política”. In ZALUAR, A. e ALVITO, M. (eds.). Um século de favela. Rio de Janeiro: FGV, 1998, pp. 209-32.

ZALUAR, A. e ALVITO, M. (eds.). Um século de favela. Rio de Janeiro: FGV, 1998.

ZICCARDI, A. "Villas miseria y favelas: sobre las relaciones entre las instituciones del Estado y la organización social en las democracias de los años sesenta”. Revista Mexicana de Sociologia, v. XLV, n. 1, pp. 45-67, jan. 1983. 


\section{SOBRE O AUTOR}

Alexis Cortés é Doutor em Sociologia pelo Instituto de Estudos Sociais e Políticos da Universidade do Estado do Rio de Janeiro (IESP-UERJ), Mestre em Sociologia pelo Instituto Universitário de Pesquisas do Rio de Janeiro (IUPERJ) e sociólogo formado na PUC-Chile. É professor auxiliar do Departamento de Sociologia da Universidad Alberto Hurtado em Santiago do Chile, onde é diretor do programa de mestrado em Sociologia. Contato: acortes@uahurtado.cl 